Júlia Rabetti Giannella

\title{
Dispositivo infovis: \\ interfaces entre visualização da informação, infografia e interatividade em sítios jornalísticos
}

Dissertação apresentada à Escola de Comunicações e Artes da Universidade de São Paulo para obtenção do título de Mestre em Ciências da Comunicação

Área de Concentração: Estudos dos Meios e da Produção Mediática. Linha de Pesquisa: Consumo e Usos Midiáticos nas Práticas Sociais. Orientadora: Prof ${ }^{a}$ $\mathrm{Dr}^{\mathrm{a}}$ Sandra Maria Ribeiro de Souza

São Paulo 
Autorizo a reprodução e divulgação total ou parcial deste trabalho, por qualquer meio convencional ou eletrônico, para fins de estudo e pesquisa, desde que citada a fonte.

Giannella, Júlia Rabetti

Dispositivo infovis: interfaces entre visualização da informação, infografia e interatividade em sítios

jornalísticos / Júlia Rabetti Giannella. -- são Paulo: J. R. Giannella, 2014 .

189 p.: il. + CD.

Dissertação (Mestrado) - Programa de Pós-Graduação em Ciências da Comunicação - Escola de Comunicações e Artes / Universidade de são Paulo.

Orientadora: Sandra Maria Ribeiro de Souza

Bibliografia

1. Jornalismo on-line 2. Design da informação 3 .

Infografia 4 . infovis 5 . Interatividade I. Souza, Sandra Maria Ribeiro de II. Título. 


\section{Folha de aprovação}

Júlia Rabetti Giannella

Dispositivo infovis: interfaces entre visualização da informação, infografia e interatividade em sítios jornalísticos

Dissertação apresentada à Escola de Comunicações e Artes da Universidade de São Paulo para obtenção do título de Mestre em Ciências da Comunicação.

\section{Aprovado em:}

Banca examinadora

Prof. Dr.:

Julgamento:

Instituição:

Assinatura:

Prof. Dr.:

Julgamento:

Instituição:

Assinatura:

Prof. Dr.:

Julgamento:

Instituição:

Assinatura: 


\section{Agradecimentos}

À Professora Dra Sandra Maria Ribeiro de Souza, pela orientação e pelo apoio sempre presentes.

À Secretaria de Pós-Graduação e à biblioteca da Escola de Comunicações e Artes, pela assistência acadêmica.

À Capes, pela concessão de bolsa de mestrado para a realização da pesquisa .

À minha família, namorado e amigos, pelo suporte incondicional e por compreenderem as ausências dos últimos tempos. 
GIANNELLA, J. R. Dispositivo infovis: interfaces entre visualização da informação, infografia e interatividade em sítios jornalísticos. 2014. 189 f. Dissertação (Mestrado) - Escola de Comunicações e Artes, Universidade de São Paulo, 2014.

A pesquisa busca alcançar novos aportes para estudos em infografia jornalística à medida que investiga qualidades, atividades profissionais e tecnologias envolvidas na produção de uma modalidade infográfica emergente, o infovis, contextualizada pelas potencialidades do meio digital e on-line, e sintonizada com práticas comunicacionais contemporâneas, que supera, em determinados aspectos, modelos infográficos anteriores. Com vistas a atingir nosso objetivo investigativo adotamos metodologia de pesquisa em duas etapas: 1) revisão conceitual de três referências teóricas fundamentais - visualização da informação, infografia jornalística e interatividade; e 2) proposta de análise de infovis com base na técnica de pesquisa de análise de conteúdo. Assim, o corpus empírico é constituído por 270 infovis de conteúdo temático político, sobretudo eleitoral, de quatro sítios jornalísticos - The New York Times, The Guardian, Folha de S. Paulo e O Estado de S. Paulo - veiculados entre jan. 2010 e dez. 2013. A partir de sistemático procedimento de análise elaborado segundo unidades e subunidades analíticas orientadas pelas três dimensões teóricas do dispositivo infovis (input, interface e output), obtivemos respostas codificadas para todas as peças do corpus. A leitura do formulário de análise preenchido gerou resultados e inferências sobre nossa amostra que apontam para aspectos produtivos pioneiros em infografia, como maior abertura comunicacional à audiência, emprego de ferramentas on-line e gratuitas para produção de infovis e utilização de tecnologia de atualização contínua dos dados visualizados.

Palavras-chave: Jornalismo on-line. Design da informação. Infografia. Infovis. Visualização da informação. Interatividade. Base de dados. 
GIANNELLA, J. R. Infovis device: interfaces between information visualization, infographics and interactivity on journalistic websites. 2014. 189 f. Dissertation (Master's degree) - Escola de Comunicações e Artes, Universidade de São Paulo, 2014.

The research seeks to offer new contributions for studies on journalistic infographics by investigating the qualities, professional activities, and technologies involved in the production of an emerging form of infographics, the infovis, within the context of the potential of online environments, in synch with contemporary communications practices, and which overcomes, in certain aspects, previous infographics models. In order to meet our research objective, we employed a two-stage method: 1) conceptual review of three fundamental theoretical subjects - information visualization, journalistic infographics, and interactivity; and 2) a proposal for the analysis of infovis based on the technique of content analysis research. Thus, the empirical corpus is made up of 270 examples of infovis with political thematic content, mainly electoral, from four journalistic websites - The New York Times, The Guardian, Folha de S. Paulo and O Estado de S. Paulopublished between January 2010 and December 2013. Based on a systematic procedure for analysis, organized by analytical units and subunits, as well as by the three theoretical facets of the infovis device (input, interface and output), we obtained codified responses for all pieces within the corpus. From the reading of the completed analysis form, results and inferences were generated for our sample, which point to pioneering productive features in infographics, such as greater communicative openness with the audience, use of free online tools for the production of infovis, and use of real-time technology for on-screen data.

Keywords: Online journalism. Information design. Infographics. Infovis. Information visualization. Interactivity. Database. 


\section{Observações iniciais aos leitores}

Com exceção dos termos "design" e "designer," as demais palavras estrangeiras são apresentadas nesta dissertação em itálico. O termo "sítio" é utilizado em detrimento de sua versão estrangeira site.

As citações de textos em idioma estrangeiro foram traduzidas por nós.

Este trabalho é acompanhado de CD contendo a versão digital da dissertação e o anexo para o formulário de análise de conteúdo preenchido. $\mathrm{O}$ formulário de análise também está disponível na web no seguinte endereço:

- <http://goo.gl/bfQac0>

Por motivo de limitação de espaço, não apresentamos imagens de todos os 270 infovis analisados no corpus da dissertação impressa. Contudo, quatro galerias virtuais foram criadas pela autora contendo imagens e hyperlinks para as peças constituintes da amostra, a saber:

- The New York Times

$<$ http://br.pinterest.com/juliagiannella/infovis

-the-new-york-times $>$;

- The Guardian

$<$ http://br.pinterest.com/juliagiannella/infovis -the-guardian>;

- Folha de S. Paulo

$<$ http://br.pinterest.com/juliagiannella/infovis -folha-de-s-paulo $>$ e

- O Estado de S. Paulo $<$ http://br.pinterest.com/juliagiannella/infovis -o-estado-de-s-paulo $>$. 
Figura $1 \quad$ DIKW model ...................................... p. 23

Figura 2 Livro One Million ........................... p. p. 29

Figura 3 Cédula eleitoral da cidade de Palm Beach ................................... p. 32

Figura 4 Linha do tempo da visualização da informação ..................................... p. 34

Figura 5 Modos de implantação e variáveis visuais p. 47

Figura 6 The best stats you've ever seen ........ p. 51

Figura $7 \quad$ Pesquisa Eyetracking ....................... p. p. 62

Figura $8 \quad M r$. Blight's House .......................... . p. 64

Figura 9 A navegação Brasileira ................... p. 65

Figura 10 Infográfico vencedor do Malofiej Awards em 2014 ............................. p. p. 68

Figura 11 Etapas da análise de conteúdo ....... p. 87

Figura 12 Galeria de infovis da Folha de S. Paulo

Figura 13 Esquema representativo das dimensões e unidades de análise da seção caracterização p. 106

Figura 14 Etapas de codificação e redução ..... . p. 119

Figura 15 Voter apathy 1964-2010: What's changed? p. 124

Figura 16 Local elections 2013: results mapped

Figura 17 Veja quem é mais popular: Dilma ou o governador

Figura 18 A evolução do custo dos partidos para os cofres públicos

Figura 19 Cartograma p. 129

Figura 20 Quatro infovis com qualidade de atualização contínua 
Figura 21 At the Democratic Convention, the Words Being Used ..................... p. p. 140

Figura 22 Obama's 2011 Budget Proposal ..... p. 141

Figura 23 The Electoral Map ........................... p. 142

Figura 24 Over the Decades, How States Have Shifted ......................................... p. 143

Figura 25 The Election Will Be Tweeted (and Retweeted) ............................... p. 145

Figura 26 Estadão de Dados ............................ p. 150

Figura 27 Abordagens comunicacionais ....... p. 156

Figura 28 Estrutura copo de Martini .............. p. 158

Figura 29 Corruption index 2010 ...................... p. 159

Figura 30 Estrutura slideshow interativo ....... p. 160

Figura 31 Diferentes configurações visuais para The Electoral Map ................... p. p. 162

Figura 32 Estrutura de profundidade ............. p. 163

Figura 33 Basômetro ....................................... p. 164

Figura 34 Gay Marriage bill: how did your MP vote? ................................... p. 168

Figura 35 Flickr da seção Datablog ................. p. p. 169

Figura 36 You decide the 2012 US presidential election .......................... p. 174

Figura 37 Do you think Scotland should become independent? ....................... p. 175

Figura 38 What One Word Describes Your Current State of Mind? ..................... p. p. 176 
Gráfico 1 Aumento da produção infográfica p. 75 no suporte on-line

Gráfico 2 Atualização contínua cruzada p. 134 com temática

Gráfico 3 Distribuição de infovis por natureza de hibridização e por veículo comunicativo

Gráfico 4 Distribuição de infovis por veículo comunicativo e por editoria p. 149

Gráfico 5 Média do gradiente de mediação e do gradiente de interatividade, por veículo comunicativo

Gráfico 6 Guia para interpretar o modelo comunicacional do dispositivo infovis

Gráfico 7 Distribuição de infovis por veículo comunicativo e por ação participativa 
Quadro 1 Inflação de dados ........................... p. 25

Quadro 2 Escala de Iconicidade p. 36

Decrescente

Quadro 3 Hierarquia de definições de trabalho relacionadas à visualização da informação

p. 40

Quadro 4 Atividades, tecnologias e objetivos da visualização de dados

Quadro 5 Taxonomia de tipos de representação gráfica da visualização

Quadro 6 Relações entre os dados observados por diferentes autores p. 45

Quadro 7 Gerações e produtos do jornalismo on-line p. 58

Quadro 8 Definições e extensões de uso da infografia p. 69

Quadro 9 Gerações da infografia no suporte on-line p. 77

Quadro 10 Ações participativas p. 85

Quadro 11 Relação da amostra de infovis do The New York Times p. 94

Quadro 12 Relação da amostra de infovis do The Guardian

Quadro 13 Relação da amostra de infovis da Folha de S. Paulo p. 99

Quadro 14 Relação da amostra de infovis de O Estado de S. Paulo p. 100

Quadro 15 Distribuição das unidades e subunidades de análise p. 107

Quadro 16 Recursos do gradiente de mediação p. 111

Quadro 17 Recursos do gradiente de interatividade p. 114 
Tabela 1 Distribuição de infovis analisados por veículo de comunicação

p. 102

Tabela 2 Resultados da dimensão input de análise

Tabela 3 Resultados da dimensão interface de análise

Tabela 4 Resultados da dimensão output de análise

Tabela 5 Média de gradientes de mediação e de gradiente de interatividade por veículo comunicativo

Tabela 6 Codificação dos gradientes de Corruption index 2010

Tabela 7 Codificação dos gradientes de The Electoral Map p. 161

Tabela 8 Codificação dos gradientes do Basômetro p. 164 


\section{Sumário}

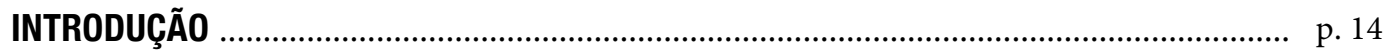

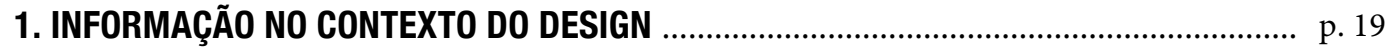

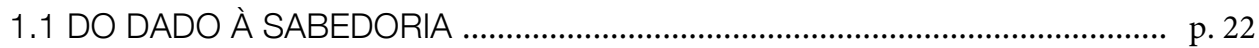

1.2 COMUNICAÇÃO NA ERA DA INFORMAÇÃO EXCEDENTE ....................... p. 25

1.3 VISUALIZAÇÃA DA INFORMAÇÃO ………………................................... p. 34

1.3.1 Revisão terminológica e conceitual ................................................... p. 34

1.3.2 Classificação da representação gráfica …………………………...... p. 43

1.3.3 Tornando a realidade visível e tangível ............................................ p. 48

2. JORNALISMO ON-LINEE REPRESENTAÇÃO VISUAL …….......................................... p. 53

2.1 ESTILO JORNALÍSTICO ................................................................................ p. 53

2.1.1 Características do jornalismo on-line ................................................ p. 55

2.2 REPRESENTAÇÃO VISUAL NO JORNALISMO ……....................................... p. 60

2.2.1 Infografia jornalística ........................................................................ p. 62

2.2.2 Infografia: um breve apanhado histórico ............................................ p. 63

2.2.3 Divergências de terminologia, conceito e extensão de uso .................. p. 66

2.2.4 Infografia no suporte digital e on-line ................................................ p. p 75

2.2.5 Infovis como dispositivo interacional ............................................... p. 80

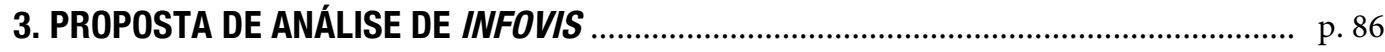

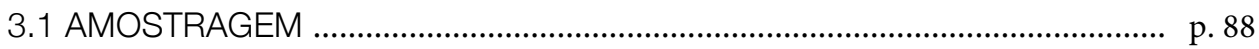

3.1.1 Escolha dos sítios jornalísticos ................................................. p. 88

3.1.2 Escolha do período de análise ...................................................... p. 90

3.1.3 Escolha da categoria de conteúdo analisada ................................. p. 90

3.1.4. Delimitação do corpus .................................................... p. 92

3.2 UNITIZAÇÃO ......................................................................................... p. 104

3.2.1 Dimensão de input do dispositivo .................................................... p. 108

3.2.1.1 Unidade tecnologia ........................................................ p. 108

3.2.2 Dimensão de interface do dispositivo ............................................... p. 110

3.2.2.1 Unidade design ............................................................... p. 110

3.2.2.2 Unidade tratamento jornalístico ......................................... p. 111

3.2.3 Dimensão de output do dispositivo ................................................ p. 114

3.2.3.1 Unidade interatividade …................................................... p. 114

3.2.3.2 Unidade participação ........................................................ p. 116

3.3 CODIFICAÇÃO E REDUÇÃO …................................................................... p. 119

4. INTERPRETAÇÃO DOS DADOS …………………................................................. p. 121

4.1 DIMENSÃO INPUT ................................................................................ p. 121

4.1.1 Ferramenta de produção ............................................................. p. 122

4.1.2 Atualização contínua ....................................................................... p. 132

4.2 DIMENSÃO INTERFACE ........................................................................... p. 136

4.2.1 Modo de organização da informação ................................................ p. 137

4.2.2 Temática ....................................................................................... p. 146

4.3 DIMENSÃO OUPUT ..................................................................................... p. 151

4.3.1 Gradiente de mediação versus gradiente de interatividade .............. p. 152

4.3.1.1 Abordagens direcionadas pelo autor e pelo usuário ................. p. 155

4.3.1.2 Extração de dados .............................................................. p. 166

4.3.2 Conteúdo gerado pelo usuário ...................................................... p. 172

CONSIDERAÇÕES FINAIS _.......................................................................................... p. 178

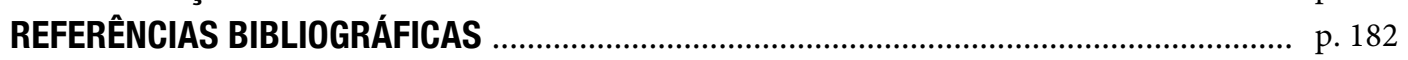




\section{Introdução}

A presente pesquisa de mestrado é resultado do entrelaçamento de três referências teóricas e práticas abordadas por quem transita entre áreas da Comunicação Social e do Design: visualização da informação, infografia jornalística e interatividade. Da interligação entre esses três eixos emerge o infovis, neologismo assumido por nós para designar objeto de estudo emergente e pioneiro, contextualizado pelo fenômeno do Big Data, ${ }^{1}$ que inaugura práticas pioneiras em jornalismo de dados, e pelas tecnologias e potencialidades do meio digital e on-line, que proporcionam o desenvolvimento de produtos midiáticos com novas qualidades.

A definição do tema origina-se de percurso investigativo construído desde a defesa da monografia de graduação, em 2010, quando se optou por estudar e desenvolver infográficos jornalísticos impressos sobre a Copa do Mundo de Futebol, realizada na África do Sul. A trajetória profissional também contribui com desdobramentos sobre o assunto da pesquisa: a passagem da função de diagramadora no jornal impresso O Globo (2009-2011) ao posto de designer de interface para tablets na Editora Abril (2011-2012) suscitou uma série de reflexões sobre a transição dos produtos midiáticos impressos para plataforma digital e on-line, sobretudo acerca dos novos formatos para infográficos com base em dados e suas possibilidades interativas. Finalmente, o encontro desses interesses investigativos com a supervisão de uma orientadora inserida na linha de pesquisa Consumo e Usos Midiáticos nas Práticas Sociais, com tradição de estudo em Design da Informação, possibilitou a realização da presente dissertação.

O exercício intelectual é atividade, muitas vezes, não linear, apoiada em flexões e reflexões, descobertas e retornos. Por configurar-se como produto midiático interdisciplinar, extremamente atual, em transformação e sintonizado com práticas comunicacionais contemporâneas, a proposta de estudo sobre o objeto infovis é tarefa desafiadora. É como falar sobre algo que começa a ser discutido por

\footnotetext{
${ }^{1}$ Big Data é expressão usada para descrever o acelerado crescimento de dados. Em 2001, o Grupo Gartner, Centro de Pesquisa em Tecnologia da Informação, estabelecido em Connecticut, Estados Unidos, definiu desafios e oportunidade do crescimento vertiginoso de dados por meio da avalição de três parâmetros: volume crescente (quantidade de dados), velocidade (entrada e saída de dados) e variedade (tipos e fontes de dados).
} 
várias áreas do conhecimento, possui diferentes denominações, abordagens e extensões de uso, e, portanto, carece de referências teóricas e práticas integradas e consolidadas. É nesse sentido que o projeto original foi reformulado ao longo de dois anos e meio de pesquisa, tornando-se cada vez mais claro e coerente quanto a seus propósitos, acompanhando, sempre que possível, discussões acadêmicas e profissionais a respeito do tema tão logo divulgadas. Partindo destas observações, a dissertação estrutura-se, em capítulos e subcapítulos, de forma a, primeiramente, apresentar definições e contextos de cada referência fundamental da pesquisa visualização da informação, infografia jornalística e interatividade -, para, a partir de suas interações, propor objetivos investigativos e procedimentos metodológicos para um objeto comunicacional em emergência o infovis, ${ }^{2}$ que, em definição inicial, constitui-se como um infográfico interativo baseado no cruzamento de dados.

Assim, o primeiro capítulo tem como pano de fundo a transformação dos processos comunicacionais diante da saturação de dados gerados e disponibilizados de forma gratuita e acessível por meio de um modelo circulatório e multidirecional em rede, que denominamos web. Nesse cenário, o controle sobre a coleta de dados brutos e suas transformações em informações significativas, realizadas em grande parte pelos mediadores, constitui grande desafio e desejo para os mais diversos setores da denominada Sociedade da Informação, entre os quais empresas de comunicação. É nesse sentido que abordamos a visualização da informação modalidade de organização e apresentação visual da informação que pertence ao universo maior constituído pelo Design da Informação - como alternativa para manipular dados e proporcionar fluxos comunicativos dialógicos. A visualização da informação proporciona à sociedade novos usos da informação bem como modos alternativos de aquisição e produção de conhecimento, facilitando a compreensão de grande quantidade de dados uma vez que evidencia suas relações - quantitativas, geográficas, temporais, grupais e conectivas - em processo tanto dirigido pela mediação dos comunicadores como orientado por atividades de sense-making ${ }^{3}$ realizadas pelo polo receptor.

\footnotetext{
${ }^{2}$ Infovis, reiteramos, é neologismo assumido por nós para designar o objeto estudado na presente dissertação caracterizado pela convergência da visualização da informação, da infografia jornalística e da interatividade.

${ }^{3}$ A expressão sense-making é utilizada para designar um processo comunicacional e bidirecional no qual interagentes, individual ou coletivamente, participam das atividades de produção de sentido (DERVIN, 2000).
} 
O segundo capítulo traça breve panorama do jornalismo on-line, apontando características do suporte em rede que significam adaptação e desenvolvimento de atividades e produtos jornalísticos orientados para a emergente conjuntura tecnológica-social. Diante de novas possibilidades produtivas e novas dinâmicas de trabalho, o infográfico jornalístico - uma manifestação do jornalismo visual ancorada, tradicionalmente, na união de imagem, texto e elementos esquemáticos com finalidade informativa - se renova e sinaliza a necessidade de incluir, na discussão acerca da disciplina infografia, aspectos como análise e cruzamento de dados, interatividade e participação do usuário. É nesse contexto que evidenciamos o surgimento de uma precursora modalidade infográfica, o infovis, que introduz novos formatos e dinâmicas de apresentação e narrativa jornalísticas, considerando a natureza heterogênea dos dados e a complexidade informativa contemporânea. Assim, o infovis compreende dispositivo midiático que conjuga, em sua interface, modalidades e organizações visuais oriundas da visualização da informação para representar e comunicar conteúdos jornalísticos baseados em dados, ao mesmo tempo em que oferece recursos interativos que permitem aos usuários tornar-se mais ativos no processo comunicacional, explorando e, em alguns casos, ressignificando conteúdos visualizados.

Uma vez situado nosso objeto de estudo, definimos que a questão central dessa pesquisa seria compreender aspectos do dispositivo infovis que o diferenciam de outras modalidades infográficas e que o sintonizam com práticas comunicacionais contemporâneas. Dessa forma, delineia-se cenário investigativo marcado por duas abordagens comunicacionais com ênfases diferentes, mas não excludentes: modelo direcionado pelo autor, que representa infovis mais explanatórios, com ênfase na linearidade, mediação e tratamento narrativo-jornalístico e modelo direcionado pelo usuário, que representa infovis marcados pelo grau relativamente maior de autonomia que cada usuário tem de participar de seus percursos informacionais e buscar significações por meio de recursos interativos de exploração do conteúdo e ações participativas. Em torno dessa questão central, estabelecemos os seguintes objetivos de pesquisa abordados no terceiro capítulo: 
1. desenvolver um protocolo de análise orientado pelas dimensões que caracterizam o infovis como um dispositivo interacional no jornalismo on-line: tecnologia de produção (input), mediação comunicacional (interface) e interatividade (output);

2. delimitar um corpus de análise que possa ser submetido ao protocolo de análise, gerando resultados específicos e inferências estendidas;

3. a partir da interpretação dos dados codificados segundo o protocolo de análise, gerar resultados e inferências sobre o panorama atual e futuro para a produção de infovis em sítios jornalísticos.

O terceiro capítulo apresenta, em detalhes, a metodologia de pesquisa adotada para responder aos objetivos levantados. De modo geral, estudos consultados sobre infográficos, impressos ou digitais, apresentam dois caminhos para delimitação do corpus: 1) exemplos ilustrativos dentro de determinada proposta de análise e 2) oposição entre boas e más soluções, em termos sintáticos e pragmáticos. No entanto, diante do fato de nosso objeto ser pouco discutido e sistematizado, consideramos mais interessante, do ponto de vista investigativo, adotar procedimento metodológico por amostragem, selecionando infovis com diversos níveis de complexidade de produção. Dessa forma, nosso corpus é composto por uma variedade de peças, desde as premiadas em concursos de infografia àquelas que passam despercebidas dos olhares de estudiosos e especialistas. Para delimitação do corpus, apresentamos proposta de análise de infovis de conteúdo político, sobretudo eleitoral, por meio da técnica de pesquisa análise de conteúdo. Segundo procedimentos criteriosos, a análise de conteúdo compreende uma importante e dispendiosa etapa da nossa pesquisa, a elaboração dos dados, que é desdobrada em quatro subetapas. Na primeira subetapa, unitização, são elaboradas unidades e subunidades de análise orientadas pelas três dimensões teóricas do dispositivo infovis (input, interface e output); na segunda, amostragem, é delimitado um corpus de análise contendo 270 infovis de recorte temático político, publicados em período de quatro anos (jan. 2010 a dez. 2013) e procedentes de quatro sítios jornalísticos (The New York Times, The Guardian, Folha de S. Paulo e O Estado de S. Paulo); na terceira, codificação, realiza-se preenchimento do formulário de análise segundo operações previstas na unitização; finalmente, durante a redução, são realizados procedimentos de depuração do protocolo de análise. 
A interpretação dos dados, apresentada no quarto capítulo, é resultado de leitura sistemática realizada ora por meio de operações de média absoluta da ocorrência das respostas de cada subunidade de análise, ora por meio de cruzamentos entre respostas de determinadas subunidades a fim de buscarem-se relações entre elas. Resultados específicos para o corpus, assim como inferências que podem expandir-se para outros infovis e possíveis encaminhamentos para produção infográfica realizada no ambiente on-line, são discutidos e confrontados com referências teóricas exploradas e com os objetivos de análise propostos.

Nas Considerações Finais, retomamos inferências e resultados discutidos, enfatizando que eles não esgotam possibilidades de interpretação dos dados da análise, mas constituem aspectos que consideramos mais relevantes para delimitar potencialidades, cenários futuros e desafios para o infovis que, em última análise, repercutem na ampliação investigativa sobre o estado da arte da disciplina infografia. De modo geral, as conclusões da análise sobre infovis encaminham-se para duas principais reflexões. Primeiramente, a polarização entre dois modelos comunicacionais - 'dirigido pelo autor' e 'dirigido pelo usuário' - desdobra-se no conflito entre procedimentos de controle versus ações de abertura estabelecidos pelos veículos jornalísticos e seus produtos midiáticos. Em segundo lugar, o exercício interdisciplinar e as inovações tecnológicas, aos quais se submetem a disciplina infografia e as atividades profissionais a ela relacionadas, repercutem em questões como democratização de tecnologias de produção infográfica, tensões e articulações entre especialistas e não especialistas em design e renovação do processo produtivo jornalístico nas fases de apuração, produção e circulação do conteúdo. 


\section{Informação no contexto do Design}

O Design da Informação pode ser compreendido como disciplina que atua no processo comunicacional facilitando a compreensão de uma mensagem ou como atividade que exerce ações em torno da organização, planificação e apresentação de determinada informação. Como disciplina ou atividade profissional, a fundamentação teórica do Design da Informação é escassa, e isso ocorre por dois principais motivos: 1) embora alguns autores reconheçam a prática do Design da Informação desde as primordiais pinturas das cavernas do homem pré-histórico, ${ }^{1}$ o exercício intelectual e acadêmico a seu respeito é recente e pouco sistematizado e 2) sua prática é extremamente dependente do contexto em que ela se realiza, o que dificulta uma metodologia que possa ser replicada na análise e avaliação de seus objetos. Todavia, se não há receitas para o Design da Informação, existem aspectos fundamentais que devem ser considerados durante seu processo, a saber: a definição dos objetivos (por quê?; para quê?); a quem nos dirigimos (para quem?), a definição do contexto (onde e quando?) e a estrutura da informação (por quais meios?).

Horn (2000), ao defender que o Design da Informação é uma das mais recentes manifestações da Comunicação, o definiu como “[...] a arte ou a ciência de preparar a informação de maneira que ela possa ser usada pelos indivíduos com mais eficiência e efetividade" (HORN, 2000, p. 15). O autor identifica três objetivos para o Design da Informação:

1. desenvolver documentos compreensíveis para assimilação rápida e precisa, e que sejam facilmente convertidos em ações efetivas;

\footnotetext{
${ }^{1}$ Existem divergências a respeito do início das atividades constituintes básicas do Design da Informação. Horn (2000, p. 17) identifica a origem e história do Design de Informação a partir de invenções de unidades comunicativas específicas (gráfico de barras e linhas do tempo, por exemplo), o que só teria ocorrido no século XVIII. Já Meggs e Purvis (2009, p. 18-19) reconhecem nas pinturas rupestres - nas marcas, símbolos, figuras e letras traçadas ou escritas sobre uma superfície - formas naturais de comunicar ideias, de registrar e transmitir informação.
} 
2. projetar interações fáceis, naturais e prazerosas para interfaces homemcomputador;

3. auxiliar pessoas a encontrar caminhos em espaços tridimensionais com conforto e facilidade, especialmente em ambientes urbanos, mas também em espaços virtuais.

Esses três objetivos podem ser encaminhados para finalidade mais geral e ampla: “[...] assegurar a efetividade da comunicação mediante a facilitação dos processos de percepção, leitura, compreensão, memorização e uso da informação apresentada" (FRASCARA, 2011 p. 11). Com essas palavras, Frascara sugere que a essência do Design de Informação é necessariamente centrada no usuário e em suas necessidades, o que faz com que o objetivo primordial de sua atividade se desloque da produção de objetos em si para a produção de sentidos para e pelo público:

A noção do design centrado no usuário parte do pressuposto de que o objetivo do design não é a produção de objetos, mas a geração de reações desejadas nas pessoas. O problema central do designer de informação é a criação de meios que sirvam para as pessoas aprenderem, recordarem, aturarem, interagirem (com objetos, pessoas e informações), realizarem seus desejos e satisfazerem suas necessidades (FRASCARA, 2000, p. 23).

Justamente porque são produzidos para ser usados - o que estabelece sua intencionalidade pragmática - os produtos do Design da Informação, sem as excluir, afastam-se de certas faculdades do Design Gráfico e das Belas Artes: aspectos estilísticos e estéticos devem ser secundários em relação aos princípios de claridade, precisão, legibilidade, compreensibilidade e simplicidade (HORN, 2000, p. 25), que operam para que a informação se torne acessível, apropriada, atrativa, confiável, concisa, completa, relevante, oportuna e compreensível (FRASCARA, 2011 p. 10). O Design da Informação não substitui as capacidades do Design Gráfico e de outras disciplinas visuais, mas estabelece a estrutura pela qual elas são expressas (SHEDROFF, 2000, p. 270). O exemplo a seguir evidencia essa diferença:

[...] capas de discos. Um mesmo objeto mostra a diferença entre o Design Gráfico (na capa) e o Design da Informação (na contracapa). $\mathrm{Na}$ frente, pode-se passar qualquer 
mensagem, pode-se até contrariar a mensagem do artista, se ele, e/ou o produtor, assim o quiser, ou concordar, naquele momento, naquele lançamento. Às vezes não é necessário nem escrever o nome do artista, na frente. Mas, do outro lado, eu, como usuário, quero saber rapidamente sem esforço [...] além do nome do artista, quais são as músicas, os autores, os músicos [...]. Tudo em tipo de letra não menor que Corpo 9 (REDIG, 2004, p. 49).

O processo do Design da Informação ocorre em dois momentos distintos: a organização da informação (o conteúdo e suas unidades de sentido, textos e imagens) e a codificação e implementação de sua apresentação visual. Essas tarefas requerem habilidades e conhecimentos interdisciplinares para processar, organizar e apresentar a informação em formas linguísticas (escrita) e não linguísticas (a imagem em seu sentido mais amplo), e resultam em uma multiplicidade de sistemas texto-visuais como, por exemplo, projeto gráfico de livros, sinalização de ambientes, design instrucional de materiais didáticos e, finalmente, visualização de informações, que será explorada mais densamente nesta dissertação. A visualização da informação é um produto do Design da Informação que não tem fim em si mesmo e pode ser compreendido como potencial modalidade comunicacional.

Tentativas de teorização sobre a disciplina estabelecem perspectivas interessantes sobre o Design da Informação: não há nada de natural na informação. Ela é sempre construída (DERVIN, 2000, p. 36). A autora assim propõe o conceito de sense-making, isto é, um processo comunicacional e bidirecional no qual indivíduos, individual ou coletivamente, participam dos processos de produção de sentido. Como consequência, “[...] o design da informação é, de fato, metadesign: design sobre design, design para ajudar indivíduos a fazer e desfazer suas próprias informações, seus próprios sentidos" (DERVIN, 2000, p. 43). Essa abordagem do Design da informação, embora possa ser problematizada em determinados discursos de efeito informacional, sobretudo no Jornalismo, aproxima-se da forma como pretendemos tratar a visualização da informação, em seu sentido estrito, um processo comunicacional de representação visual de dados que, ao mesmo tempo em que transmite e explana ideias segundo um ponto de vista, possibilita a exploração do conteúdo por meio de diálogo interativo com o receptor e, consequentemente, estimula formulação de pensamento e geração de sentidos. A perspectiva de Dervin encontra eco na defesa de Frascara (2011) de que mensagens produzidas pelo Design da Informação não são 
apenas recebidas, mas sim interpretadas pelas pessoas (FRASCARA, 2011, p. 9). Para o autor trata-se, sobretudo, de um processo comunicacional bidirecional emissor $<-$ >interpretante, e que atualizaremos, dentro de nossos propósitos, para produtor<>usuário, no qual este último interagente busca estabelecer significações mediante processo interativo que amplifica sua cognição. Nessa mesma linha de pensamento, dois conceitos interligados nas atividades relacionadas ao Design da Informação são distinguidos: edificação e comutatividade (JACOBSON, 2000, p. 2). Enquanto o primeiro termo se refere ao processo de iluminação estabelecido no sentido emissor $>$ receptor, o segundo destaca a ação mútua entre produtor e usuário envolvida no processo de significação. Embora as duas lógicas, muitas vezes, coexistam nos produtos derivados do Design da Informação, nossa ênfase será na segunda, pois ela reconhece e utiliza a natureza interativa e relacional da Comunicação.

Por produtos de Design da Informação compreendemos: design editorial (livros, revistas, etc.); tabelas alfanuméricas (horários e diversos tipos de tabelas); representações gráficas como gráficos, diagramas e infográficos; material didático; documentos administrativos (formulários, boletos, etc.); instruções visuais (manuais, regras de jogos, bulas de remédios, etc.); sistemas de sinalização; catálogos, programas, prospectos de exposições; interfaces para meios eletrônicos (FRASCARA, 2011). Dentro desse amplo e difuso conjunto de possibilidades, nos concentramos em uma modalidade específica de infográficos que, no jornalismo on-line, se configura como um dispositivo comunicacional que articula três dimensões em seu processo produtivo: 1) input (tecnologia), interface (mediação de designers e jornalistas) e output (recursos interativos de exploração do conteúdo e ações participativas).

\subsection{DO DADO À SABEDORIA}

O aumento da quantidade de informação disponível e acessível requer ampliação do campo da arquitetura da informação, saber focado na combinação de princípios do design e da arquitetura em espaços digitais, para que os dados possam ser organizados e gerar sentido (WURMAN, 1991). Diante desse cenário, o autor sugere que o grande 
desafio da era da informação é evitar a ansiedade da informação, ${ }^{2}$ isto é, evitar o buraco negro entre dado e conhecimento.

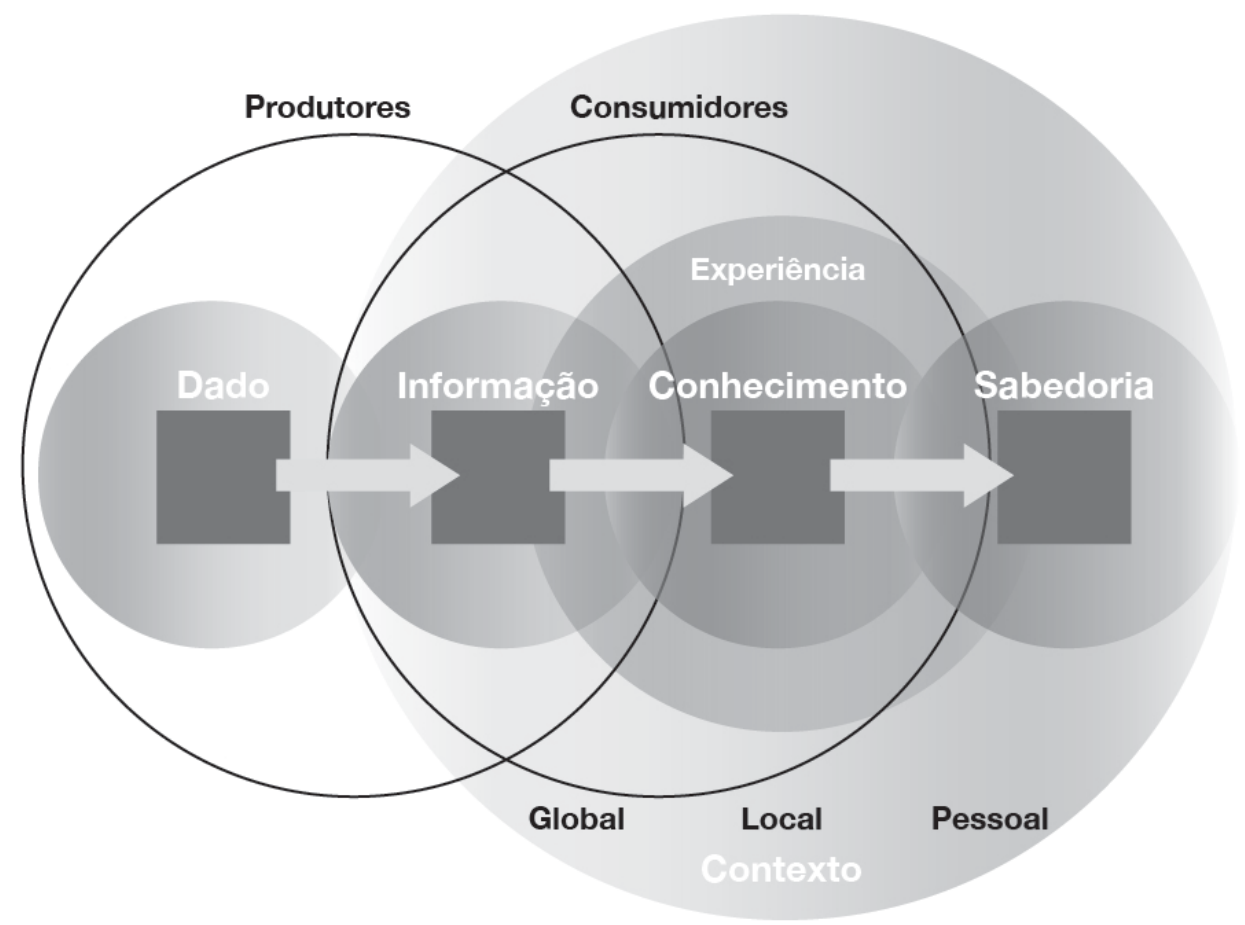

Figura 1 - DIKW model. Fonte: Shedroff, 2000, p. 271.

Essa lacuna é evidenciada na Figura 1, o DIKW model $^{3}$ (data, information, knowledge, wisdom), esquema proposto por Shedroff (2000, p. 271) no qual os dois extremos da máxima de Wurman (dado e conhecimento) são apresentados. No modelo, quatro conceitos, frequentemente associados ao tratamento visual de mensagens comunicativas, dado $>$ informação $>$ conhecimento $>$ sabedoria, são evidenciados de forma contínua. Ao propor o esquema, Shedroff atualizou esses quatro conceitos para o contexto contemporâneo das mídias digitais, tornando-o conhecido entre os que estudam ou trabalham com Design e Arquitetura da Informação.

Dados (data) são produtos de pesquisa, criação, coleta ou descoberta. Constituem o material bruto utilizado na construção de mensagens comunicativas. Para ser entregues aos consumidores, precisam transformar-se e organizar-se em

\footnotetext{
${ }^{2}$ Ansiedade da informação é a tradução da expressão information anxiety, cunhada por Wurman e que intitulou seu livro.

${ }^{3}$ DIKW model é um modelo amplamente estudado no campo da arquitetura da informação. Diversos autores estudaram e reformularam o modelo, sendo que o que apresentamos no presente trabalho é oportuno para nossos propósitos.
} 
informação (information), de maneira a revelar conteúdos e relações significativas. Essa transformação abrange, no mínimo, dois momentos do Design da Informação: 1) uma organização lógica dos dados e 2) uma apresentação apropriada da estrutura. É exatamente nessa transformação (dados > informação) que os comunicadores assumem suas funções mediadoras, e a visualização da informação torna possível a construção do conhecimento ao revelar padrões subjacentes aos dados (DÜRSTELER, 2000, p. 24). O conceito de informação é ontologicamente relacionado à ideia de causalidade (PASQUALL, 2005). Para o autor, o termo informação pode ser rastreado desde a era clássica "[...] denotando a interpenetração ou imposição de uma forma, ideia ou princípio, com ou em matéria, que assim se tornava 'in-formada' ou 'formada"' (PASQUALL, 2005, p. 25). Informar conota a mensagem transmitida unidirecionalmente a um receptor passivo que terá seu comportamento direta e imediatamente afetado. Em contraponto à ideia de Comunicação, informação expressa um relacionamento comunicativo menos equilibrado e "[...] tende a produzir mais verticalidade do que igualdade, mais subordinação do que reciprocidade [...]" (PASQUALL, 2005, p. 25). Não à toa, o uso do termo informação foi, durante décadas, quase monopolizado por jornalistas. Conhecimento (knowledge) e sabedoria (wisdom) são etapas pertencentes à esfera dos consumidores da informação e correspondem a graus diferentes de compreensão das informações apresentadas, processadas e internalizadas por meio de experiências pessoais e intransferíveis. O conhecimento é a compreensão alcançada via a experiência do usuário e implica a construção de interações com indivíduos ou com ferramentas de modo que os padrões e significados em suas informações possam ser percebidos e aprendidos pelos usuários em contexto local. A sabedoria é a compreensão profunda do conhecimento adquirido, sendo extremamente pessoal e abstrata. Não podemos criar sabedoria assim como coletamos dados e os transformamos em informações, nem podemos compartilhá-la como fazemos com o conhecimento. Finalmente, a sabedoria constitui um nível de compreensão que só pode ser obtido individualmente.

A partir dessas definições, percebemos o modelo proposto por Shedroff (2000) como um processo contínuo que começa nos dados e termina na sabedoria, passando pela informação e pelo conhecimento. 
A apresentação clara e efetiva da informação - objetivo dos processos e produtos do Design da Informação, particularmente a infografia jornalística - constituise, por esse modelo, na base do processo de aquisição de conhecimento.

\subsection{COMUNICAÇÃO NA ERA DA INFORMAÇÃO EXCEDENTE}

"Uma edição do The New York Times em um dia da semana contém mais informação do que o comum dos mortais poderia receber durante toda uma vida na Inglaterra do século XVIII” (WURMAN, 1991, p. 36). Com essa afirmação, publicada originalmente em 1989, Wurman alerta-nos para a velocidade da produção de informação que já se instituía na sociedade há três décadas e que hoje nomeamos como o fenômeno do Big Data. A preocupação do autor dirigia-se ao fato de que o aumento gradativo de dados, fatos e números não gera, necessariamente, conhecimento, pois entre os dois níveis do DIKW model (dados e conhecimento) é preciso haver a transformação clara e significativa de dados em informação.

A revista inglesa The Economist publicou, no início de 2010, a previsão do International Data Corp (IDC), empresa especializada em pesquisa de mercado, de que a quantidade de dados digitais gerados naquele ano atingiria 1.200 exabytes, sendo um exabyte equivalente a 10 bilhões de cópias de uma publicação (Quadro 1). É verdade que grande parte dos bytes gerados é produto de processos automáticos somente entre computadores e outros dispositivos e, a princípio, não servem para gerar conhecimento efetivo para os leitores; ainda assim, é grande o desafio de manipular e apresentar a massa de dados para que esses possam ser estruturados em informações significativas e gerar sentidos.

Quadro 1 - Inflação de dados

\begin{tabular}{|lll|}
\hline Unidade & Tamanho & O que significa \\
\hline Bit $(\mathbf{b})$ & 1 ou 0 & $\begin{array}{l}\text { Abreviação para binary digit (dígito binário), código } \\
\text { binário (1 ou 0) utilizado pelos computadores para } \\
\text { armazenar e processar dados. }\end{array}$ \\
Byte $(\mathbf{B})$ & 8 bits & $\begin{array}{l}\text { Informação suficiente para criar uma letra ou } \\
\text { número no código computacional. É a unidade } \\
\text { básica da computação. }\end{array}$ \\
\end{tabular}




\begin{tabular}{|c|c|c|}
\hline Kilobyte (KB) & 1.000 ou $2^{10}$ bytes & $\begin{array}{l}\text { De "mil" em grego. Uma página de texto corrido } \\
\text { equivale a } 2 \mathrm{~KB} \text {. }\end{array}$ \\
\hline $\begin{array}{l}\text { Megabyte } \\
(\mathrm{MB})\end{array}$ & $1.000 \mathrm{~KB}$ ou $2^{20}$ bytes & $\begin{array}{l}\text { De "grande" em grego. A obra completa de } \\
\text { Shakespeare totaliza } 5 \mathrm{MB} \text {. Uma típica música pop } \\
\text { tem cerca de } 4 \mathrm{MB} \text {. }\end{array}$ \\
\hline Gigabyte (GB) & $1.000 \mathrm{MB}$ ou $2^{30}$ bytes & $\begin{array}{l}\text { De "gigante" em grego. Um filme de duas horas } \\
\text { pode ser comprimido em 1-2GB. }\end{array}$ \\
\hline Terabyte (TB) & $1.000 \mathrm{~GB}$ ou $2^{40}$ bytes & $\begin{array}{l}\text { De "monstro" em grego. Todos os livros catalogados } \\
\text { da Biblioteca do Congresso (Washington, D.C., } \\
\text { Estados Unidos) totalizam 15TB. }\end{array}$ \\
\hline Petabyte (PB) & $1.000 \mathrm{~TB}$ ou $2^{50}$ bytes & $\begin{array}{l}\text { Todas as cartas entregues pelos correios americanos } \\
\text { este ano alcançarão cerca de 5PB. O Google } \\
\text { processa cerca de } 1 \mathrm{~PB} \text { por hora. }\end{array}$ \\
\hline Exabyte (EB) & $1.000 \mathrm{~PB}$ ou $2^{60}$ bytes & Equivale a 10 bilhões de cópias do The Economist. \\
\hline Zettabyte (ZB) & $1.000 \mathrm{~EB}$ ou $2^{70}$ bytes & $\begin{array}{l}\text { 1.2ZB é a quantidade total de informação existente } \\
\text { prevista para ser alcançada este ano. }\end{array}$ \\
\hline $\begin{array}{l}\text { Yottabyte } \\
\text { (YB) }\end{array}$ & $1.000 \mathrm{ZB}$ ou $2^{80}$ bytes & Demasiadamente grande para se imaginar. \\
\hline Nota: Os $\mathrm{p}$ & foram esta & $\begin{array}{l}\text { nal de padronização The } \\
\text { (ZB) foram adicionados em }\end{array}$ \\
\hline
\end{tabular}

Fonte: The Economist, $2010 .^{4}$

Três atividades podem ser associadas à difusão da informação no processo comunicacional: armazenamento, transmissão e compreensão (WURMAN, 1991, p. 54). O modelo transmissionista (emissor $>$ mensagem $>$ canal $>$ receptor), que por muito tempo vigorou como modelo tradicional de comunicação de massa, atualmente renova-se para paradigmas mais dialógicos, nos quais: 1) transmissão atualiza-se em circulação (FAUSTO NETO, 2010); 2) o papel de receptor se torna complexo na atuação do usuário ou interagente e 3 ) as relações comunicativas, com base na ideia de causa e efeito, evoluem para uma concepção mais consensual, ainda que a lógica distribucionista continue presente em muitos contextos comunicacionais. Feita essa colocação, Wurman aponta que, enquanto as atividades de armazenamento e transmissão são diretamente otimizadas e desenvolvidas no contexto das tecnologias digitais (computador, hardware, software, base de dados, etc.) e pelo modelo

\footnotetext{
${ }^{4}$ Disponível em: <http://www.economist.com/node/15557421>. Acesso em jun. 2013.
} 
multimídia e multilinear que a web constitui, acompanhando a crescente produção de dados, existe um enfraquecimento da terceira atividade, a compreensão, sem a qual não existe Comunicação. Para o autor, profissionais dedicados à atividade de compreensão, responsáveis por ajudar pessoas a extrair significados dos mais diversos conteúdos, são aqueles a quem se recorreria:

[...] para tornar inteligível o censo dos Estados Unidos, obter um relatório anual com informação concreta em lugar de brilharescos (sic); preencher formulários de seguro e solicitações de empréstimos em linguagem inteligível. Redes de TV e jornais poderiam recorrer a elas para tornar as notícias internacionais compreensíveis para o público. Repartições governamentais poderiam consultá-las para garantir que a informação de interesse público realmente se tornasse pública. Os consumidores teriam a quem apelar quando não estivessem entendendo suas contas de telefone e de energia (WURMAN, 1991, p. 55, grifo nosso).

O tratamento lógico e mediado da informação precede seu tratamento gráficovisual e é, em regra, o resultado da intervenção político-criativa do ser humano ao delimitar, escolher e priorizar (e, consequentemente, reduzir) determinado domínio informativo em um número finito de dados relacionáveis entre si. “A redução lógica da informação é o meio pelo qual o homem pode aplicar ao maior conjunto possível de observações o número limitado de instantes de percepção que dispõe no curso de sua existência” (BERTIN, 1970, p. 178).

As possibilidades de atuação do Design da Informação, assim como de outras atividades da Comunicação, são claramente ampliadas no contexto de excesso de dados e da valorização do tempo e da informação evidente em nossa sociedade. Dessa forma, o Design da Informação pode tornar-se um caminho decisivo para controlar a chamada explosão da (não) informação e contribuir para sua gestão, tornando-se disciplina de considerável relevância social. Diante do aumento vertiginoso de coleta e armazenamento de dados por meio do computador e outros sistemas digitais, viabilizam-se o cruzamento e relacionamento desses dados por intermédio de listas, planilhas, tabelas, fórmulas, etc. Uma planilha Excel é um exemplo de base de dados que cumpre o primeiro momento do processo de Design da Informação: além de coletar e armazenar os dados, a planilha é capaz de organizá-los (arranjar, elencar prioridades, selecionar, excluir, comparar, etc.). No entanto, a base de dados, por si só, 
não realiza o segundo momento do Design da Informação, sem o qual leitores poderiam sentir-se perdidos diante de tanta informação: a etapa de codificação e implementação da apresentação visual.

A combinação de escrita, imagens e números constitui, para Wurman (1991, p. 62), o acesso ao mundo compreensível. Enquanto imagens têm alta densidade informativa, palavras e números têm maior poder descritivo e de diferenciação, e é por isso que mesmo apresentações predominantemente visuais utilizam recursos linguísticos para representar determinadas unidades informativas. Voltemos, porém, nossa atenção para a Comunicação Visual. Se os números, por um lado, por seu caráter absoluto e incontestável, são considerados códigos fáceis para transmissão e assimilação da informação, por outro, sua exatidão perde referência quando seus valores são muito altos. Qual a diferença entre um milhão e um bilhão?

O projeto One Million (Figura 2) reflete as potencialidades da visualidade no discurso comunicativo. Além da alta densidade informativa, certas modalidades de apresentação visual favorecem a compreensão de conteúdos gerados pelo grande fluxo e cruzamento de dados, pois elas possibilitam a visualização de conceitos abstratos, ou seja, conceitos mentais, como, por exemplo, comparações, proporções, organizações, conexões e hierarquias (FRASCARA, 2011, p. 43). A ideia fundamental do projeto One Million, de Hendrik Hertzberg - que motivou a publicação, em 1970, do livro de título homônimo -, é tornar um número grande e abstrato, no caso um milhão, um valor mais tangível e contextualizado para os leitores. Para tanto, Hertzberg projetou um livro em que cada uma de suas 200 páginas reúne 5.000 pontos, totalizando um milhão de pontos. Em cada página, alguns pontos, organizados numericamente, são destacados, seus valores são apresentados por escrito, e algumas informações estatísticas relevantes e contextualizadas a respeito dos mesmos são anotadas. 


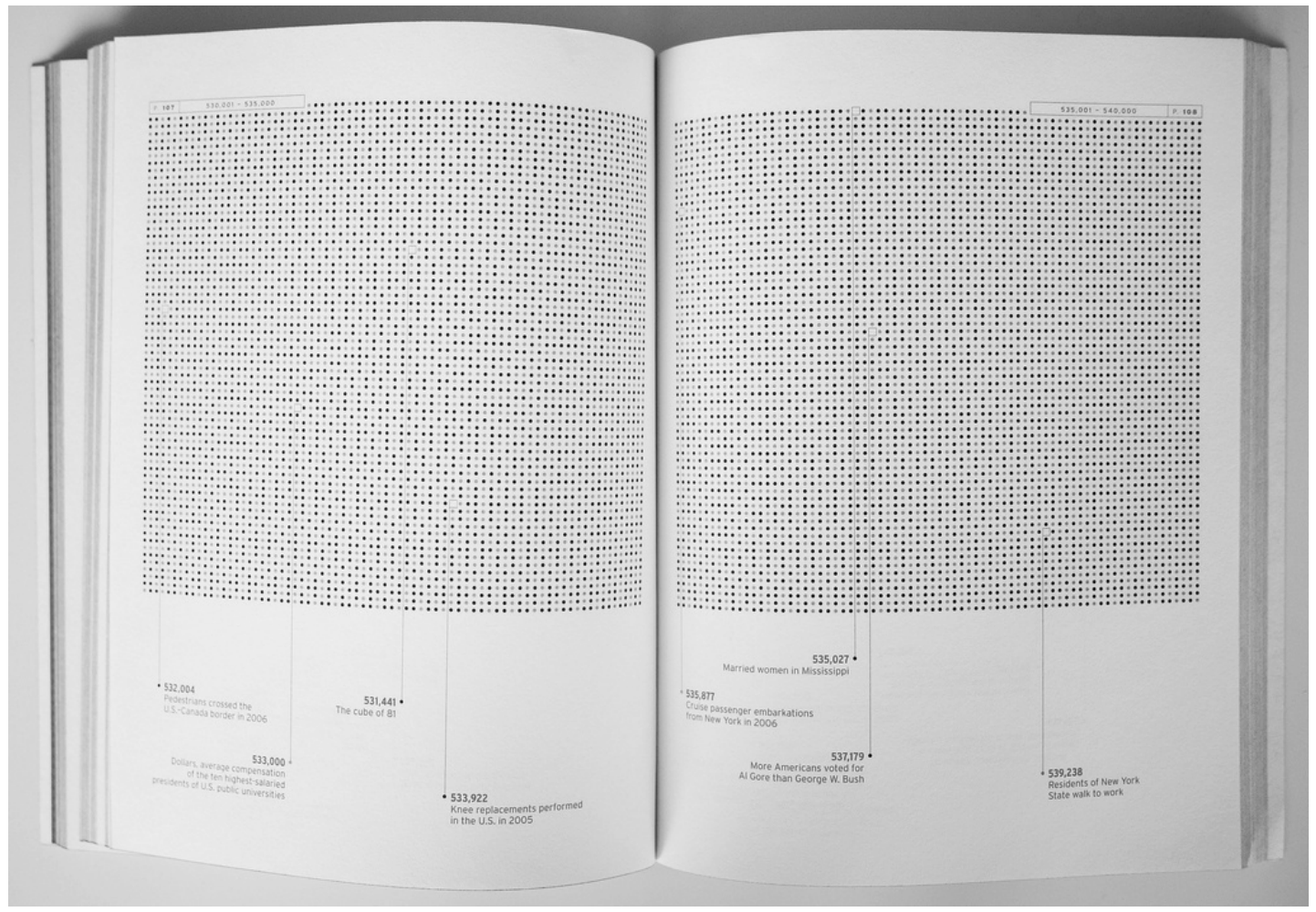

Figura 2 - Livro One Million. Fonte: Design Notes, 2010. ${ }^{5}$

Como observado na Figura 1 (p. 22), o DIKW model apresenta um modelo do processo comunicacional a partir da possível continuidade entre as unidades dado e sabedoria. Dois agentes são retratados nesse modelo: produtores - que dentro de nossa perspectiva seriam os comunicadores - e consumidores - que seriam, em contrapartida, os usuários da informação. A interação entre esses dois agentes acontece no nível da informação que, por sua vez, se constitui, para o comunicador, na etapa de transformação de dados brutos em informações significativas, por meio de sua organização e apresentação e, para o usuário, no acesso traduzido e manipulado de dados para que, mediante suas experiências ${ }^{6}$ individuais e/ou coletivas, os significados possam ser assimilados:

O designer da informação é mediador entre os dados abstratos, que integram uma informação em seu estado bruto, e suas apresentações em informações visualmente significativas, compreensíveis para o leitor (COSTA, 1998, p. 34).

\footnotetext{
${ }^{5}$ Disponível em: <http://designnotes.info/?p=3523>. Acesso em fev. 2013.

${ }^{6}$ Experiências podem ser passivas ou interativas. De um lado, temos experiências como, por exemplo, ler um livro ou assistir a um programa de televisão. Embora alguns possam argumentar que essas atividades já implicam certo grau de interação entre dispositivo e mente, nós as consideramos experiências passivas. De outro lado, temos experiências como, por exemplo, conversar, pintar, jogar. Essas atividades envolvem escolhas, controle, produção e criatividade e, por isso, as consideramos interativas (SHEDROFF, 2000, p. 283).
} 
Exatamente no ponto de transformação dados>informação, comunicadores atuam ao aplicar sua expertise na redução da complexidade cognitiva e na apresentação da informação por meio de uma interface que conjugue as fontes, as informações e os leitores (BONSIEPE, 2000, p. 6). No entanto, embora os produtores do conteúdo só alcancem, diretamente, o nível da informação, suas posturas devem projetar a produção de conhecimento para usuários. Essa abordagem propõe a superação de uma visão funcionalista sobre os produtos comunicativos a ser reconfigurados em uma perspectiva que integra contexto, interesses e práticas sociais dos consumidores. O Design da Informação pode ser compreendido, por um lado, como atividade que, para além da organização de informações complexas em uma configuração visual que facilite sua apreensão, também organiza e produz significados; em outras palavras, “[...] seu objetivo é facilitar o metabolismo cognitivo e a assimilação de conhecimento" (BONSIEPE, 2000, p. 6). Por outro lado, o Design da Informação deve considerar a natureza interativa, dialógica e de sense-making da Comunicação, a ação mútua entre produtor e usuário envolvida no processo de significação.

A ideia de mediação corresponde à percepção de que não há conhecimento direto da realidade e de que o acesso ao "real" é sempre intermediado por um ponto de vista (BRAGA, 2012a, p. 32). Tal perspectiva é compartilhada por Dervin em afirmativa segundo a qual a realidade é sempre construída a partir dos produtores da informação (DERVIN, 2000, p. 36). No entanto, sua proposta do sense-making aplicado ao Design de Informação, que se traduz em uma abordagem comunicativa frente à informação, compõe um contraponto ao conceito de mediação ao incorporar os consumidores da informação nos processos de significação da mensagem. Mediação e sense-making, como buscaremos demonstrar neste trabalho, compõem abordagens comunicacionais distintas, mas que podem integrar, simultaneamente e segundo diferentes gradientes, os dispositivos midiáticos.

A atividade de aplicar design à informação é, por vezes, chamada de Arquitetura da Informação ou Engenharia do Conhecimento. Adotamos a expressão Design da Informação em detrimento de Arquitetura da Informação, pois, a nosso ver, enquanto a última contempla, essencialmente, questões relativas à organização dos dados e dos seus caminhos de acesso (navegação, usabilidade, etc.), a primeira 
enfatiza, além da organização das informações, as relações entre conteúdo, apresentação visual e usuário. O Design da Informação é responsável por "[...] delinear a forma [visual e interativa ${ }^{7}$ na qual o usuário encontra as informações, realiza sua leitura, estabelece a relação entre os seus elementos, interage com a interface e compreende essa experiência" (PASSOS; MOURA, 2007, p. 22). Nesse sentido, estabelece-se a responsabilidade ética e social que o Design deve expressar frente aos produtos gerados para a comunicação. A falta de consideração quanto a práticas e contextos de usos da informação (incluídas situações de risco, insegurança, despreparo, nervosismo e tensão) pode significar descompromisso com o conteúdo e com a sociedade.

Redig (2004, p. 50) ao recompor uma notícia veiculada no jornal Folha de S. Paulo, em 13 de novembro de 2001, a respeito da repercussão das eleições presidenciais norte-americanas realizadas em 2000, demonstra como um problema de Design da Informação prejudicou a compreensão de milhares de usuários, afetando o resultado final da eleição. Na ocasião do pleito, a cidade de Palm Beach, Flórida, optou por aumentar o corpo tipográfico da fonte utilizada no painel de votação (Figura 3) o que acarretou diagramação da listagem de candidatos em duas colunas. $\mathrm{Na}$ contabilização dos votos, percebeu-se que, em muitos casos, Pat Buchanan candidato reformista, cuja intenção de voto em Palm Beach representava apenas algumas centenas - e Al Gore receberam votos simultaneamente em uma mesma cédula, indício de que os eleitores se confundiram quanto à posição do círculo perfurável correspondente a cada candidato (círculos posicionados na faixa amarela). Especula-se que grande parte dos votos anulados era intencionada a $\mathrm{Al} \mathrm{Gore,} \mathrm{o} \mathrm{que}$ lhe garantiria a preferência do Colégio Eleitoral da Flórida e os votos dos respectivos 25 delegados que o elegeriam como o $43^{\circ}$ presidente dos EUA.

\footnotetext{
${ }^{7}$ Reiteramos que o Design da Informação é responsável pelas estruturas visuais e interativas de um projeto. A interatividade, no entanto, diferentemente dos aspectos visuais, não é atributo inerente ao Design. Tornou-se uma de suas qualidades após o Design convergir, também, para as mídias digitais. No suporte digital, interatividade e representação visual, muitas vezes, se complementam na organização da informação, resultando, por exemplo, na criação de elementos (textos e ícones) com funções de hyperlinks que sofrem modificações em cor, tamanho, orientação, etc. ao ser clicados ou sofrer outro tipo de interação.
} 


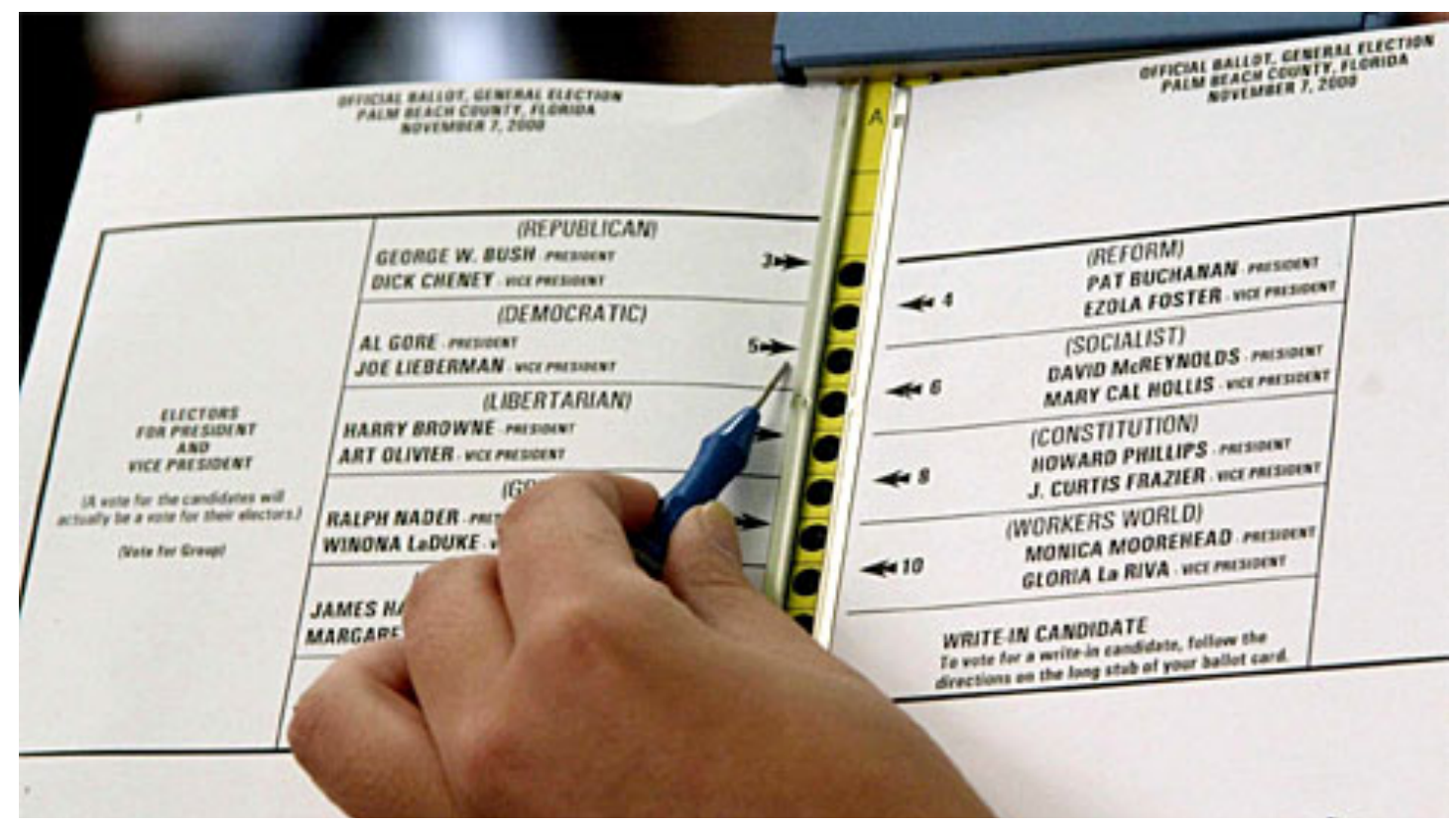

Figura 3 - Cédula eleitoral da cidade de Palm Beach. Fonte: Gauge, 2013. ${ }^{8}$

Há, no atual cenário de excesso de dados, a possibilidade de os produtores da informação atuarem como mediadores do processo comunicativo, reduzindo a complexidade informativa gerada pelo fluxo e cruzamento de dados, ao retratar a realidade sobre um ponto de vista. Paralelamente, observamos a emergência de práticas de comunicação alternativas, multilineares e descentralizadas, permitidas pelo modelo circulatório que a web constitui e pelos recursos interativos de exploração do conteúdo, que possibilitam ao usuário refletir ressignificações e usos sociais sobre a informação que consome. Podemos, portanto, problematizar os produtos comunicacionais em torno de duas abordagens que atuam sobre eles: 1) a narrativa mediada, que constrói uma hierarquização dos enunciados com objetivo de facilitar o acesso a um fato ou fenômeno e 2) o sense-making que engaja o receptor-usuário no processo de significação e de construção de seu conhecimento. Soma-se, a essas duas abordagens, a dimensão tecnológica do processo de criação dos produtos midiáticos nos meios digitais. Conteúdos gerados nesses contextos, no entanto, não podem ser concebidos sem a capacidade criadora e mediadora dos comunicadores, ao transformar dados em informações visualmente significativas. Dessa forma, compreendemos que, embora necessários, progressos em tecnologias, que possibilitam coleta, armazenamento e circulação de dados, assim como desenvolvimento de softwares e gadgets habilidosos

\footnotetext{
${ }^{8}$ Disponível em: <http://gauge.com.br/blog/um-erro-de-interface-pode-custar-uma-presidencia/>. Acesso em mar. 2013.
} 
(MANOVICH, 2001), que aprimoram e enriquecem a interface visual-interativa, não devam subjugar a ferramenta mais primária, mais essencial, mais capaz de converter dados em informações significativas e úteis: o cérebro humano:

Computadores não podem dar sentidos aos dados; só os homens podem. Mais precisamente, somente pessoas que possuem as habilidades para analisar dados podem. Computadores nos servem para fazer mais eficiente e acuradamente o que já sabemos fazer (FEW, 2009, p. 2).

Longe de estabelecer um determinismo, compreendemos que os progressos tecnológicos e o impacto das novas mídias podem condicionar uma reorientação da sociedade e de suas práticas frente às informações, estabelecendo um processo que permite novas formas de produzi-las, circulá-las e consumi-las, de sentir, ver e interpretar o mundo. Contudo, se computadores, por um lado, avançam em termos de capacidade de memória, são potentes e ágeis coletores, armazenadores e organizadores de informação, por outro lado, são limitados em termos de pensamento, imaginação e criatividade. A constatação de Wurman de que das três atividades associadas à difusão da informação transmissão, armazenamento e compreensão (WURMAN, 1991, p. 54) - a última é mais renegada trata justamente dessa questão. Enquanto nos concentramos apenas em tecnologias, esquecemos que, sem a habilidade daquele que manipula e analisa dados, não podemos gerar sentido sobre eles. Softwares inteligentes devem reforçar olhos e mentes dos comunicadores de modo a contribuir com suas habilidades técnicas para organização e apresentação do conteúdo. Esse processo, contudo, não é intuitivo, nem préprogramado (embora possa ser agilizado por uso de templates $^{9}$ ). Precisa ser estudado caso a caso, levando em conta natureza dos dados e objetivo da mensagem, tarefas que só o cérebro humano pode realizar.

Esta pesquisa enfoca aspectos e potencialidades de uma modalidade específica de representação texto-visual que favorece a comunicação, por parte dos comunicadores, e exploração, por parte dos usuários, de conteúdos jornalísticos baseados em dados e apresentados na plataforma on-line: a visualização da informação.

\footnotetext{
${ }^{9}$ Template é o modelo inicial de documento utilizado para criar novos projetos.
} 


\subsection{VISUALIZAÇÃO DA INFORMAÇÃO}

\subsubsection{Revisão terminológica e conceitual}

A visualização da informação corresponde a uma modalidade de organização e apresentação visual da informação e pertence ao universo maior constituído pelo Design da Informação. Em sentido lato, designa processo cujo objetivo é facilitar a compreensão de grande quantidade de dados e suas relações de semelhança, ordem e proporcionalidade. Constitui-se em campo interdisciplinar - com base em saberes específicos do Design da Informação, do Design de Interação, da Percepção Visual e da Comunicação Social, entre outros - com potencial de proporcionar à sociedade novos usos da informação, bem como modos alternativos de aquisição e produção de conhecimento em diversas áreas, como economia, saúde, meio ambiente, educação, política, etc. Assim como o Design da Informação, a pesquisa acadêmica sobre visualização da informação é recente e pouco sistematizada. Few (2009, p. 14), no entanto, reconstitui breve histórico das principais manifestações dessa modalidade de representação texto-visual que proporcionaram o desenvolvimento de pesquisas científicas a seu respeito:

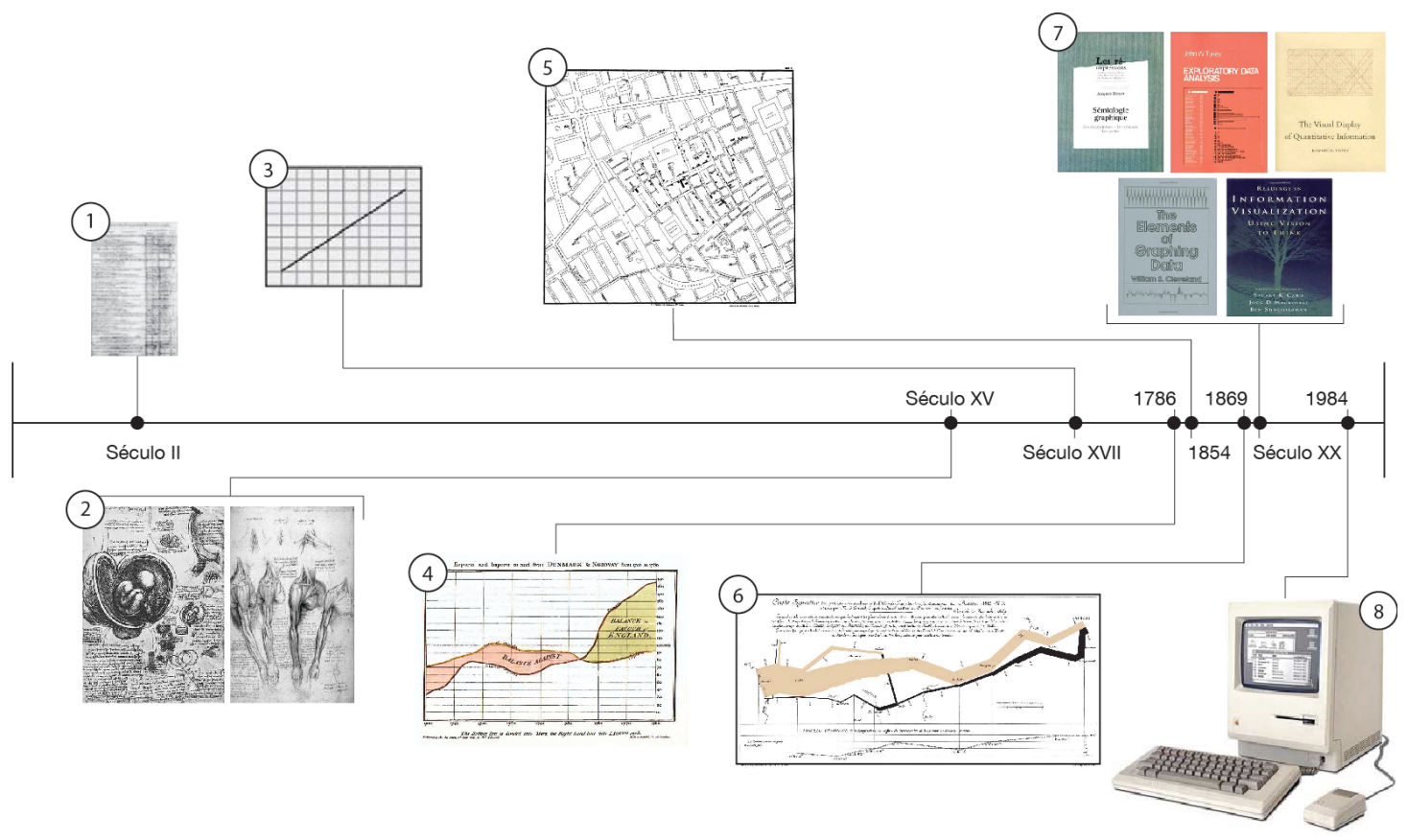

Figura 4 - Linha do tempo da visualização da informação. Fonte: elaboração própria adaptada de Few, 2009, p. 14. 
A Figura 4 reconstitui, em ordem cronológica, algumas das principais referências históricas da pesquisa em visualização da informação, com base nas contribuições de Few (2009, p. 13-17) e Cairo (2008, p. 38-61).${ }^{10}$ A linha do tempo destaca oito eventos que consideramos importantes para compreender a trajetória da visualização da informação até seu encontro com os infográficos, no campo jornalístico, e a introdução de aspectos interativos permitidos pelas mídias digitais: 1) invenção da tabela (século II); 2) ilustrações científicas renascentistas, principalmente de Leonardo da Vinci e Andrea Vesalius (séculos XV e XVI); 3) criação do gráfico cartesiano por René Descartes (século XVII); 4) gráficos desenvolvidos por William Playfair (17591823), particularmente os que compuseram os livros The Commercial and Political Atlas (1786) e Statistical Breviary (1801); 5) mapa da epidemia da cólera, criado pelo médico John Snow (1854); 6) mapa da campanha do exército Napoleônico na Rússia, de Charles Joseph Minard (1869); 7) estudos científicos e obras acadêmicas (século XX); ${ }^{11}$ e 8) popularização dos computadores domésticos (1984).

Terminologias e conceituações a respeito da visualização da informação não são convergentes, o que pode ser atribuído ao fato de serem desenvolvidas por disciplinas distintas, a saber, Engenharia, Estatística, Ciências da Computação, Design da Informação e Comunicação. Destacamos termos que, independentemente das áreas em que foram formulados, nos ajudam a caracterizar e analisar questões relativas às estruturas visuais e interativas dessa modalidade de representação: visualização da informação (CAIRO, 2008; 2013; CARD; MACKINLAY; SHNEIDERMAN, 1999; DÜRSTELER, 2003; FEW, 2009; KOSARA, 2007; MANOVICH, 2011), visualização esquemática (COSTA, 1998), visualização narrativa (CIUCCARELLI, 2012; SEGEL; HEER, 2010), gráficos da informação (BERTIN, 1986; 2010), diagrama (FRASCARA, 2011), gráficos de dados (CLEVELAND, 1994; TUFTE, 1983), representação gráfica (ENGELHARDT, 2002).

Não obstante as diferenças terminológicas, a abstração é elemento essencial e

\footnotetext{
${ }^{10}$ Para aprofundamento sobre eventos que marcaram a história da visualização da informação, é interessante conferir o projeto Milestones, desenvolvido pelos pesquisadores Michael Friendly e Daniel J. Denis, que oferece cronologia sobre cartografia temática, gráficos estatísticos e visualização de dados e está disponível em: $<$ http://datavis.ca/milestones/>. Acesso em: jun. 2013.

${ }^{11}$ Destacamos, em ordem de publicação, cinco obras acadêmicas fundamentais acerca da visualização da informação: 1) Semiology of Graphics, de Jacques Bertin (1967); 2) Exploratory Data Analysis, de John Tukey (1977); 3) The Visual Display of Quantitative Information, de Edward Tufte (1983); 4) The Elements of Graphing Data, de William Cleveland (1985) e 5) Readings in Information Visualization: Using Vision to Think, de Card, Mackinlay e Shneiderman (1999).
} 
comum à extensão conceitual de todos os termos. A abstração consiste, em contraponto à figuração, em representações visuais de baixo nível de iconicidade, isto é, menor ou nula relação indicial com seu respectivo referente. Para melhor compreender e avaliar a abstração de uma representação visual, Costa (1998, p. 104) apresenta a Escala de Iconicidade Decrescente desenvolvida por Abraham Moles, em 1970, que veio a se tornar uma das ferramentas mais completas em termos de estudo da iconografia, iconologia e esquematização. A abstração e esquematização constituem o fio condutor da escala, que situa, em 12 pontos (Quadro 2), os diferentes graus de abstração progressiva:

No início encontra-se a figuração ou iconicidade total: o objeto autorrepresentado. A abstração máxima, pelo contrário, seria a designação algébrica em que a imagem do objeto se dissolve na evocação mental constituída pelo signo arbitrário (COSTA, 1998, p. 104).

Quadro 2 - Escala de Iconicidade Decrescente

\begin{tabular}{|c|c|c|c|}
\hline Classe & Definiçãão & Critério & Exemplos \\
\hline 12 & O próprio objeto & $\begin{array}{l}\text { Objeto e imagem coincidem, } \\
\text { mas existe uma relação } \\
\text { de representação }\end{array}$ & Objetos na vitrine \\
\hline 11 & $\begin{array}{l}\text { Modelo bi ou } \\
\text { tridimensional em escala }\end{array}$ & $\begin{array}{l}\text { Cores e materiais escolhidos } \\
\text { segundo critérios arbitrários }\end{array}$ & Maquetes, esculturas \\
\hline 10 & $\begin{array}{l}\text { Esquema bi ou tridimensio- } \\
\text { nal, reduzido ou aumentado }\end{array}$ & $\begin{array}{l}\text { Cores ou materiais escolhidos } \\
\text { segundo critérios lógicos }\end{array}$ & $\begin{array}{l}\text { Mapas geológicos, } \\
\text { globo terrestre }\end{array}$ \\
\hline 9 & $\begin{array}{l}\text { Fotografia ou projeção } \\
\text { realista sobre um plano }\end{array}$ & $\begin{array}{l}\text { Projeção e perspectiva rigorosas, } \\
\text { uso de semitons e sombras }\end{array}$ & $\begin{array}{l}\text { Fotografias, cartazes, } \\
\text { catálogos ilustrados }\end{array}$ \\
\hline 8 & $\begin{array}{l}\text { Desenho ou fotografia } \\
\text { de contorno; perfis }\end{array}$ & $\begin{array}{l}\text { A imagem mantém relação } \\
\text { correta com a realidade através } \\
\text { de critérios de similaridade, } \\
\text { contorno de formas, silhueta }\end{array}$ & $\begin{array}{l}\text { Catálogos, prospectos e } \\
\text { fotografias técnicas }\end{array}$ \\
\hline 7 & $\begin{array}{l}\text { Esquemas anatômicos } \\
\text { ou de construção }\end{array}$ & $\begin{array}{l}\text { A imagem simplifica-se e pode } \\
\text { mostrar coisas que não se veem } \\
\text { à primeira vista; representam-se } \\
\text { o que se vê e o que se sabe }\end{array}$ & $\begin{array}{l}\text { Corte anatômico, corte de } \\
\text { um motor mostrando seus } \\
\text { componentes internos }\end{array}$ \\
\hline 6 & Imagem fragmentada & $\begin{array}{l}\text { Disposição perspectivada das } \\
\text { peças conforme suas relações } \\
\text { de vizinhança topológica }\end{array}$ & $\begin{array}{l}\text { Elementos técnicos em } \\
\text { manuais de instrução }\end{array}$ \\
\hline 5 & $\begin{array}{l}\text { Esquema de princípios } \\
\text { (eletricidade e eletrônica) }\end{array}$ & $\begin{array}{l}\text { Substituição dos elementos } \\
\text { por símbolos normalizados, } \\
\text { passagem da topografia à } \\
\text { tipologia; geometrização }\end{array}$ & $\begin{array}{l}\text { Plano esquematizado } \\
\text { do metrô; plano dos cabos } \\
\text { de um receptor de TV }\end{array}$ \\
\hline
\end{tabular}




\begin{tabular}{|c|c|c|c|}
\hline 4 & Organograma ou esquema & $\begin{array}{l}\text { Desaparecem todas as } \\
\text { características sensíveis, e os } \\
\text { elementos são quadros reunidos } \\
\text { por conexões lógicas, } \\
\text { hierárquicas }\end{array}$ & $\begin{array}{l}\text { Organograma de empresa, } \\
\text { de sítios da } w e b\end{array}$ \\
\hline 3 & Esquema de formulação & $\begin{array}{l}\text { Relação lógica e não topológica, } \\
\text { em espaço não geométrico, } \\
\text { entre elementos abstratos; as } \\
\text { ligações são simbólicas; todos } \\
\text { os elementos são visíveis }\end{array}$ & Fórmulas químicas \\
\hline 2 & $\begin{array}{l}\text { Esquemas em espaços } \\
\text { complexos }\end{array}$ & $\begin{array}{l}\text { Combinação, em um espaço de } \\
\text { representação, de elementos } \\
\text { esquemáticos (flechas, retas, } \\
\text { plano, objeto) pertencentes a } \\
\text { sistemas diferentes }\end{array}$ & Diagramas de forças \\
\hline 1 & $\begin{array}{l}\text { Esquema de vetores } \\
\text { em espaços abstratos }\end{array}$ & $\begin{array}{l}\text { Representação da relação entre } \\
\text { grandezas vetoriais gráficas em } \\
\text { um espaço métrico abstrato }\end{array}$ & Gráficos vetoriais \\
\hline $\mathbf{0}$ & $\begin{array}{l}\text { Descrição em palavras } \\
\text { normalizadas ou em } \\
\text { fórmulas algébricas }\end{array}$ & $\begin{array}{l}\text { Signos puramente abstratos } \\
\text { sem relação imaginável com o } \\
\text { significante }\end{array}$ & $\begin{array}{l}\text { Palavras, textos, equações, } \\
\text { fórmulas }\end{array}$ \\
\hline
\end{tabular}

Fonte: Costa, 1998, p. 105.

O universo da visualização esquemática inicia-se no nível sete da escala e cresce em termos de abstração até atingir o nível zero (COSTA, 1998, p. 104). Para o autor, correspondem a esquematizações, portanto, visualizações da informação de baixa iconicidade - como, por exemplo, planos, desenhos técnicos, visualizações científicas, etc. - e visualizações da informação de nula iconicidade ou não figurativas - como, por exemplo, mapas de dados, diagramas, gráficos e esquemas.

Os teóricos pioneiros que, a partir de enfoque predominantemente visual, sistematizaram uma teoria sobre visualizações de nula iconicidade foram Bertin, na década de 1960, que as denominou gráficos da informação (1986, 2010), e Tufte (1983), que as chamou de gráficos de dados. Para compreender as propriedades da linguagem gráfica e visual e o modo como atuam no desenvolvimento de um discurso comunicativo, Bertin $(1986,2010)$. desenvolveu pesquisas sobre a Neográfica, ou Semiologia Gráfica. Em seu estudo, o autor sistematizou um conjunto monossêmico de códigos para a construção de gráficos que poderiam ser classificados em 
diagramas, ${ }^{12}$ redes e mapas. Para relacionar os elementos gráficos, Bertin reconheceu: 1) seis variáveis visuais (tamanho, valor, cor, forma, orientação e textura); 2) três modalidades de implementação (pontos, linhas e áreas) e 3) quatro níveis de organização dos componentes (seletivo, ordinal, quantitativo e geográfico). A ideia principal dessa sistematização é que a informação significativa não reside nos dados isolados, mas sim nas relações de todo o conjunto. O tratamento gráfico oferece uma estratégia para revelar informações e relações contidas nos dados brutos, facilitando a compreensão e a produção de conhecimento.

As contribuições de Tufte (1983) enfatizam sobretudo princípios para representação de dados quantitativos (gráficos de dados) que conjugam eficiência da representação, revelação de informações complexas, simplicidade e excelência gráfica:

Em última instância, gráficos são instrumentos para raciocinar sobre informações quantitativas. Normalmente, o modo mais efetivo de descrever, explorar e resumir um conjunto de dados - mesmo um grande conjunto - é visualizar imagens desses números (TUFTE, 1983, p. 9).

A fim de sistematizar princípios para uma teoria sobre representação dos dados e avançar nos estudos comunicativos por meio da apresentação simultânea de palavras, números e imagens, Tufte reuniu saberes e habilidades específicos dos campos visualartístico e estatístico-matemático. Dessa forma, concluiu que a excelência gráfica é ilustrada por meio de quatro classes de apresentações gráficas fundamentais: mapas de dados (Data maps), linhas do tempo (Time-series), narrativas espaçotemporais (Spacetime narrative) e gráficos relacionais (Relational graphs). Essas apresentações gráficas servem às diversas possibilidades semânticas, sintáticas e pragmáticas dos dados, e compõem um sistema coeso que possibilita o desenvolvimento de uma teoria sobre gráficos de dados.

Seguindo uma linha de pensamento próxima, Cleveland (1994) desenvolve pesquisa sobre visualização de dados na ciência e na tecnologia. Segundo o autor, métodos e princípios gráficos são poderosas ferramentas para evidenciar e explorar dados (CLEVELAND, 1994, p. 1). Nesse sentido, Cleveland atribui dupla função aos

\footnotetext{
${ }^{12}$ Frascara (2001, p. 42) ao optar pelo termo diagrama para referir-se às representações não figurativas, o fez considerando o repertório teórico de Tufte (1983) e Bertin (2010). Embora o autor constate que “[...] os diagramas servem para visualizar comparações, proporções, evoluções, conexões e hierarquias” (Ibidem), entendemos que tal qualidade não pertence somente aos diagramas, já que esses, a nosso ver, correspondem a uma modalidade de esquematização que faz parte de universo maior, o da visualização da informação.
} 
gráficos de dados: 1) análise dos dados, quando o objetivo é estudar e investigar a natureza e as relações dos dados por meio de gráficos; e 2) comunicação dos dados, quando o objetivo é explanar para determinado público, por meio de gráficos, a natureza e as relações dos dados.

Quando um gráfico de dados é concebido, relações quantitativas e categóricas são encodadas por métodos de apresentação. Logo, para mensagens significativas serem apreendidas, informações precisam ser visualmente decodificadas. "Não importa o quão pertinente e interessante seja o conteúdo, nem o quão tecnologicamente impressionante seja a codificação: a visualização falha se a decodificação falhar" (CLEVELAND, 1994, p. 1). Só por meio do estudo científico da Percepção Visual e de métodos de apresentação visual podem ser concebidas eficientes e acuradas codificações visuais.

Nos estudos que se seguiram, sobretudo a partir da segunda metade dos anos 90, podemos observar adensamentos em torno da visualização da informação, assim como avanços teóricos da especialidade, além dos aspectos visuais de esquematização. Fatores como surgimento do computador e expansão da internet salientaram questões ligadas à possibilidade de uso de bases de dados, uso de softwares para a manipulação desses dados, representações visuais multidimensionais (com muitas variáveis informativas) e uso de suportes digitais para produção, circulação e apresentação do conteúdo. Nessa linha de pensamento, as contribuições de Cairo (2008; 2013), Card, Mackinlay, Shneiderman. (1999), Few (2009), Kosara (2007) e Manovich (2011) são fundamentais.

A visualização da informação, para esses autores, configura-se em um sentido mais estrito, no qual a interatividade se faz presente, e que adotaremos neste trabalho como recorte metodológico para nosso objeto, o infovis ${ }^{13}$, como o “[...] uso de representações visuais interativas de dados abstratos, auxiliado por um computador, para ampliar a cognição" (CARD, MACKINLAY, SHNEIDERMAN, 1999, p. 6-7). Para chegar a esse conceito, Card, Mackinlay e Shneiderman desenvolveram uma hierarquia de definições de trabalho, do termo mais geral ao mais específico, para todos os conceitos relacionados à visualização da informação (Quadro 3).

\footnotetext{
${ }^{13}$ Infovis é um neologismo assumido por nós para designar o objeto estudado na presente dissertação que situa-se nas interfaces de três principais referências teóricas e práticas: visualização da informação, infografia jornalística e interatividade. Para distinguir nosso objeto infovis de outras acepções e contextos de uso que o termo assume (ver p. 73, Capítulo 2.), utilizaremos o termo grafado em itálico, ao longo da dissertação.
} 
Quadro 3 - Hierarquia de definições de trabalho relacionadas à visualização da informação

Cognição externa

Design da Informação

Gráfico de dados

Visualização

Visualização científica

Visualização da informação

Fonte: Card, Mackinlay, Shneiderman, 1999, p. 7.

Das definições (CARD, MACKINLAY, SHNEIDERMAN, 1999, p. 7)

- Cognição externa: uso do mundo externo para alcançar cognição;

- Design da Informação: Design de representações externas para ampliar a cognição;

- Gráfico de dados: uso de representações visuais de dados abstratos para ampliar a cognição;

- Visualização: uso de representações visuais interativas, auxiliado por um computador, para ampliar a cognição;

- Visualização científica: uso de representações visuais interativas de dados científicos - normalmente baseados em aspectos físicos - auxiliado por um computador, para amplificar a cognição;

- Visualização da informação: uso de representações visuais interativas de dados abstratos, auxiliado por um computador, para ampliar a cognição.

Para esses autores, o termo visualização não deve ser aplicado às configurações apresentadas e acessíveis em interfaces impressas, como o papel, por exemplo. A representação visual de dados em suportes não auxiliados por um computador se configuraria como gráfico de dados (data graphics). Já a subdivisão da categoria visualização em visualização científica e visualização da informação ocorre em termos da natureza dos dados. Para a primeira, é necessário haver espaços físicos ou dados físicos (corpo humano, Terra, moléculas, ou seja, informações visíveis). Para a segunda, é necessário haver informações não físicas, como dados financeiros, dados de negócios, coleção de documentos, conceitos abstratos, etc. (CARD, MACKINLAY, SHNEIDERMAN, 1999, p. 6-7). Essa diferença conceitual é partilhada por Costa (1998, p. 62-81), que associa visualização científica aos fenômenos invisíveis a olho nu, mas 
que, pela mediação de instrumentos como microscópios, scanners, etc. podem ser revelados e compreendidos. No entanto, diferentemente de Card, Mackinlay e Shneiderman (1999), o autor não inclui o computador como requisito fundamental à visualização informativa, enfatizando apenas a necessidade de "[...] critérios de síntese e inteligibilidade com fins comunicacionais" (COSTA, 1998, p. 113).

Kosara (2007) reitera a importância da abstração para diferenciar uma visualização da informação de outras formas de representações visuais, mas utiliza outra expressão para designar essa qualidade: dados abstratos são, para o autor, dados não visuais. E conclui: “[...] visualização não é processamento de imagem, nem fotografia; se a fonte dos dados é uma imagem e ela é representada como imagem no resultado final, então ela não está sendo visualizada" (KOSARA, 2007, p. 632). Já Manovich (2011) menciona os termos abstração e não visual, embora defina visualização da informação como “[...] mapeamento entres dados discretos e uma representação visual” (MANOVICH, 2011, p. 3, destaque nosso).

Para o dicionário Aurélio visualizar é “1) Tornar visível, mediante manobra ou procedimento; 2) Formar ou conceber uma imagem visual mental de (algo que não se tem ante os olhos no momento)". Dessa forma, também pela perspectiva terminológica é possível deduzir que, em seu sentido mais amplo, a visualização da informação apoiase fundamentalmente na capacidade humana de produzir e apreender informações por meio de abstrações visuais, e que seu objetivo maior é ampliar a cognição. Assim também o compreende Dürsteler (2003) que, após identificar e reunir definições sobre visualização da informação e passar por questões ligadas ao computador e à interatividade, retorna ao sentido mais lato do termo ao defini-lo como "[...] processo de interiorização do conhecimento mediante a percepção da informação ou, se assim se preferir, mediante a elaboração dos dados" (DÜRSTELER, 2003, p. 22). Concordamos com a compreensão de que o uso de computadores não estabelece condição determinante para que haja visualização da informação, pois sua justificativa maior, dentro da abordagem comunicacional, é facilitar a compreensão, o que pode ser alcançado dentro das limitações e potencialidades de qualquer suporte. Como objetivo de pesquisa, entretanto, pretendemos verificar de que modo aspectos interativos de exploração do conteúdo auxiliam nos processos de significação, e, portanto, a produção por meio de computadores faz-se necessária para que a interatividade ocorra. 
Few $(2009$, p. 12) utiliza a expressão visualização de dados como termo guardachuva que cobre tanto a visualização da informação como a visualização científica, compreendidas a partir das definições de Card, Mackinlay e Schneiderman (1999). Assim como estes últimos, Few desmembra e define termos envolvidos na conceituação de visualização da informação conforme descrito no Quadro 4:

Quadro 4 - Atividades, tecnologias e objetivos da visualização de dados

\begin{tabular}{|ll|}
\hline \multicolumn{1}{|c|}{ Visualização de dados } \\
\hline Atividades & $\begin{array}{l}\text { Exploração } \\
\text { Sense-making } \\
\text { Tecnologias }\end{array}$ \\
Visualização da informação \\
Visualização científica \\
Objetivos imediatos & Compreensão \\
& Boas decisões
\end{tabular}

Fonte: Few, 2009, p. 12.

Embora prefiramos assumir a visualização da informação como processo, e não como tecnologia, o Quadro 4 ajuda-nos a compreender que sua atividade comunicativa é alcançada mediante a exploração do conteúdo ou sense-making, tarefas realizadas nas etapas tanto de produção como de consumo da mensagem visualizada. A visualização, portanto, é tanto o meio pelo qual jornalistas e designers analisam e investigam relações entre dados para, então, os transformar em informações significativas e visualmente estruturadas, como o produto midiático final, no qual o usuário busca interpretar um conjunto de dados:

Visualização pode ser descrita como o mapeamento de dados em formatos visuais que favorecem a interação humana em um ambiente de trabalho para o sense-making visual (CARD; MACKINLAY; SHNEIDERMAN, 1999, p. 17).

Além disso, o Quadro 4 reitera nossa perspectiva de que os objetivos da visualização da informação não incluem a produção de produtos com fins em si mesmos, mas antes, por meio deles, estabelecer processos de significação

\footnotetext{
${ }^{14}$ Provocar decisões fundamentadas, nos usuários da informação, constitui o grau máximo de afetação que um produto do Design pode alcançar. Entretanto, qualificar boas decisões é tarefa que não nos cabe nesta dissertação, de modo que nos ateremos à compreensão como objetivo final de uma visualização da informação.
} 
intermediados, por um lado, pelo tratamento editorial-gráfico dos comunicadores e, por outro, pelos percursos de exploração de conteúdo dos usuários.

\subsubsection{Classificação da representação gráfica}

Muitas propostas de classificação para representações gráficas podem ser encontradas na literatura acadêmica. Algumas foram desenvolvidas especificamente para aplicação na infografia jornalística - Peltzer (1992), Moraes (1998), Leturia (1998), De Pablos (1999), Sancho (2001), Nichani e Rajamanickam (2003) -, outras especificamente para aplicação nas modalidades de visualização esquemática Shneiderman (1996), Lengler e Eppler (2007), Heer, Bostock e Ogievetsky (2010). Também é possível encontrar autores que propõem uma classificação para as representações gráficas de forma mais ampla, sem delimitar campo de aplicação e suporte (impresso ou digital). São eles Tufte (1983), Richards (1984), Wurman (1991), Holmes (1993), Engelhardt (2002), Roam, (2008) e Bertin (2010).

Destacamos, neste momento, classificações desenvolvidas especificamente para a modalidade de visualização da informação (Quadro 5). Nosso objetivo é ilustrar métodos e técnicas de representação que vêm sendo considerados, pela academia, próprios da visualização da informação, sedimentando, dessa forma, uma modalidade específica e diferenciada de representação visual. Taxonomias são importantes instrumentos de reflexão sobre determinados objetos. No entanto, são simplificações que buscam sistematizar produtos e processos e, dificilmente, abarcam, na área da Comunicação Visual, todas as possibilidades criativas e de hibridização.

Quadro 5 - Taxonomia de tipos de representação gráfica da visualização

\begin{tabular}{|c|c|}
\hline Autor(es) & Taxonomia \\
\hline $\begin{array}{l}\text { Shneiderman } \\
\text { (1996) }\end{array}$ & $\begin{array}{l}\text { O autor propõe uma taxonomia para visualização da informação em sete } \\
\text { classes definidas pelo tipo de dados e/ou relaçôes representadas, a saber: } \\
\text { unidimensional - documento textual, código de programação, etc. -; } \\
\text { bidimensional - mapa geográfico, planta baixa, etc. -; tridimensional - } \\
\text { objetos físicos como corpo humano, edifícios, etc. -; temporal - linha do } \\
\text { tempo -; multidimensional - visualizações bidimensionais ou } \\
\text { tridimensionais com outras dimensões controladas por botões ou barras } \\
\text { deslizáveis -; tree - visualizações com estruturas hierárquicas entre } \\
\text { elementos -; rede - visualizações com estruturas de relação entre elementos. }\end{array}$ \\
\hline
\end{tabular}


Lengler e Epler Os autores classificam os métodos de visualização em seis categorias, de (2007) acordo com sua funcionalidade predominante - visualização de dados, visualização da informação, visualização conceitual, visualização metafórica, visualização estratégica e visualização composta -, cada uma contendo diversas técnicas de visualização. A categoria visualização da informação, por exemplo, contém as técnicas de linha do tempo, coordenadas paralelas, treemaps, etc.

Heer, Bostock Os autores classificam a visualização da informação em cinco grupos e Ogievetsky principais de acordo com o tipo e organização do dados e identificam, (2010) para cada grupo, técnicas que consideram mais avançadas: série cronológica - gráfico de colunas empilhadas, pequenos múltiplos, etc.; distribuição estatística - gráfico Q-Q, coordenadas paralelas, etc.; mapa mapa choropleth, cartograma, etc.; Hierarquia - treemap, círculos agrupados, etc.; rede - diagrama de arco, etc.

Fonte: elaboração própria.

Embora critérios de categorização e escolha terminológica variem nas propostas de classificação apresentadas no Quadro 5, é possível identificar certas distinções entre categorias de representações gráficas que são mantidas. Isso acontece, segundo Engelhardt (2002, p. 137), porque os critérios para a maioria das classificações de representação gráfica baseiam-se na combinação de duas lógicas, a saber:

- formato da estrutura sintática representada;

- tipos de relações entre dados representados.

A visualização da informação é, para Card, Mackinlay e Shneiderman (1999) e Few (2009), a representação de dados abstratos; para Kosara (2007), a representação de dados não visuais; para Manovich (2011), a representação de dados discretos. Independentemente dos termos que qualificam os dados, há, em todos os autores, a ideia de que a visualização da informação é um meio de ampliar a cognição sobre significações que não estão claras em um conjunto de dados que não são físicos. No momento em que esses dados são representados visualmente emergem, no entanto, relações significativas. Visualizar é perceber relações de diferente ordens entre os dados. E é na percepção dessas relações que reside o poder comunicativo das visualizações.

Buscando destacar características semântico-sintáticas que nos permitam discernir uma visualização da informação de outras representações visuais, propomos o reconhecimento de tipos de relações entre dados representados, pois esses são mais facilmente identificáveis do que, por exemplo, estilos de estrutura sintática. 
Bertin (2010) foi um dos primeiros sistematizadores da linguagem gráfica a preconizar que a informação significante não reside nos dados representados isoladamente, mas sim nas relações que podem ser visualizadas. Dessa forma, Bertin reconhece três tipos de relação que podem ser estabelecidos entre os dados e que são denominados, pelo autor, níveis de organização dos componentes:

- seletivo: relação observável de semelhança ou diversidade entre dados;

- quantitativo: relação observável de mensuração (variação ou proporção) entre dados;

- ordinal: relação observável de organização sequencial entre dados.

Bertin identifica um quarto nível de organização que pode ser observado em mapas, a relação geográfica. Essa é percebida quando elementos são dispostos em um plano de modo que sua organização geográfica na superfície da Terra seja reconhecível no entanto, dados geográficos representados isoladamente são evidências físicas. Para que um mapa possa ser considerado uma visualização da informação é necessário que relações de outras ordens (seletiva, quantitativa ou ordinal) sejam evidenciadas no plano.

Autores posteriores a Bertin apresentaram modificações terminológicas e divergências conceituais quanto ao comportamento dos dados em representações gráficas. É possível, contudo, estabelecer uma aproximação entre as classificações. ${ }^{15}$

Quadro 6 - Relações entre os dados observados por diferentes autores

\begin{tabular}{|llllll|}
\hline $\begin{array}{l}\text { Bertin } \\
(\mathbf{2 0 1 0})\end{array}$ & $\begin{array}{l}\text { Wurman } \\
\mathbf{( 1 9 9 1 )}\end{array}$ & $\begin{array}{l}\text { Engelhardt } \\
\mathbf{( 1 9 9 6 )}\end{array}$ & $\begin{array}{l}\text { Card, } \\
\text { Mackinlay, } \\
\text { Shneiderman } \\
\mathbf{( 1 9 9 9 )}\end{array}$ & $\begin{array}{l}\text { Richards } \\
\mathbf{( 2 0 0 0 )}\end{array}$ & $\begin{array}{l}\text { Nós } \\
\mathbf{( 2 0 1 4 )}\end{array}$ \\
\hline Seletivo & Categoria & Categórico & Nominal & $\begin{array}{l}\text { Agrupamento } \\
\text { Ligação }\end{array}$ & Grupal \\
Quantitativo & Hierarquia & Quantitativo & Quantitativo & Variação & Quantitativo \\
Ordinal & Tempo & Ordinal & Ordinal & - & Temporal \\
Geográfico & Localização & Espacial & - & - & Geográfico \\
\hline
\end{tabular}

Fonte: elaboração própria.

\footnotetext{
${ }^{15}$ Não incluímos no Quadro 6 algumas categorias por considera-las não observáveis em visualizações da informação no Jornalismo. São elas: 1) alfabeto, proposto por Wurman (1991); 2) randômico, proposto por Engerlhardt e 3) desestruturado, proposto por Card, Mackinlay e Shneiderman (1999).
} 
Utilizaremos neste trabalho o reconhecimento de cinco tipos de relações entre dados que correspondem a modos de organização da informação. Eles irão compor uma subunidade de análise em nossa pesquisa com base nas seguintes classificações:

- grupal: modo de organização que evidencia relação de agrupamento ou separação entre dados;

- conectivo: modo de organização que evidencia relação de ligação entre dados. Normalmente é representada pelo uso de setas e linhas conectoras;

- quantitativo: modo de organização que evidencia relações mensuráveis de variação e proporção entre dados. Normalmente é representado por eixos métricos e divisões proporcionais;

- temporal: modo de organização que evidencia relações de ordem temporal e sequencial entre dados;

- geográfico: modo de organização que evidencia relação espacial no plano terrestre. Normalmente é representada por meio de mapas com diferentes graus de esquematização.

Uma visualização da informação deverá possuir ao menos uma relação quantitativa, temporal, grupal, conectiva. No caso da relação geográfica, deve ser acompanhada por mais uma relação, constituindo, por exemplo, uma mapa de dados (TUFTE, 1983) ou uma cartografia temática (CAIRO, 2008).

As relações entre dados são expressas, em uma visualização da informação, por três modos de implantação no plano - ponto, linha e área. Esses, por sua vez, são representados por meio das duas dimensões do plano e seis variáveis visuais tamanho, valor, cor, forma, orientação e textura (BERTIN, 2010). Modos de implantação podem ser combinados com variáveis visuais, como demonstra a Figura 5. 


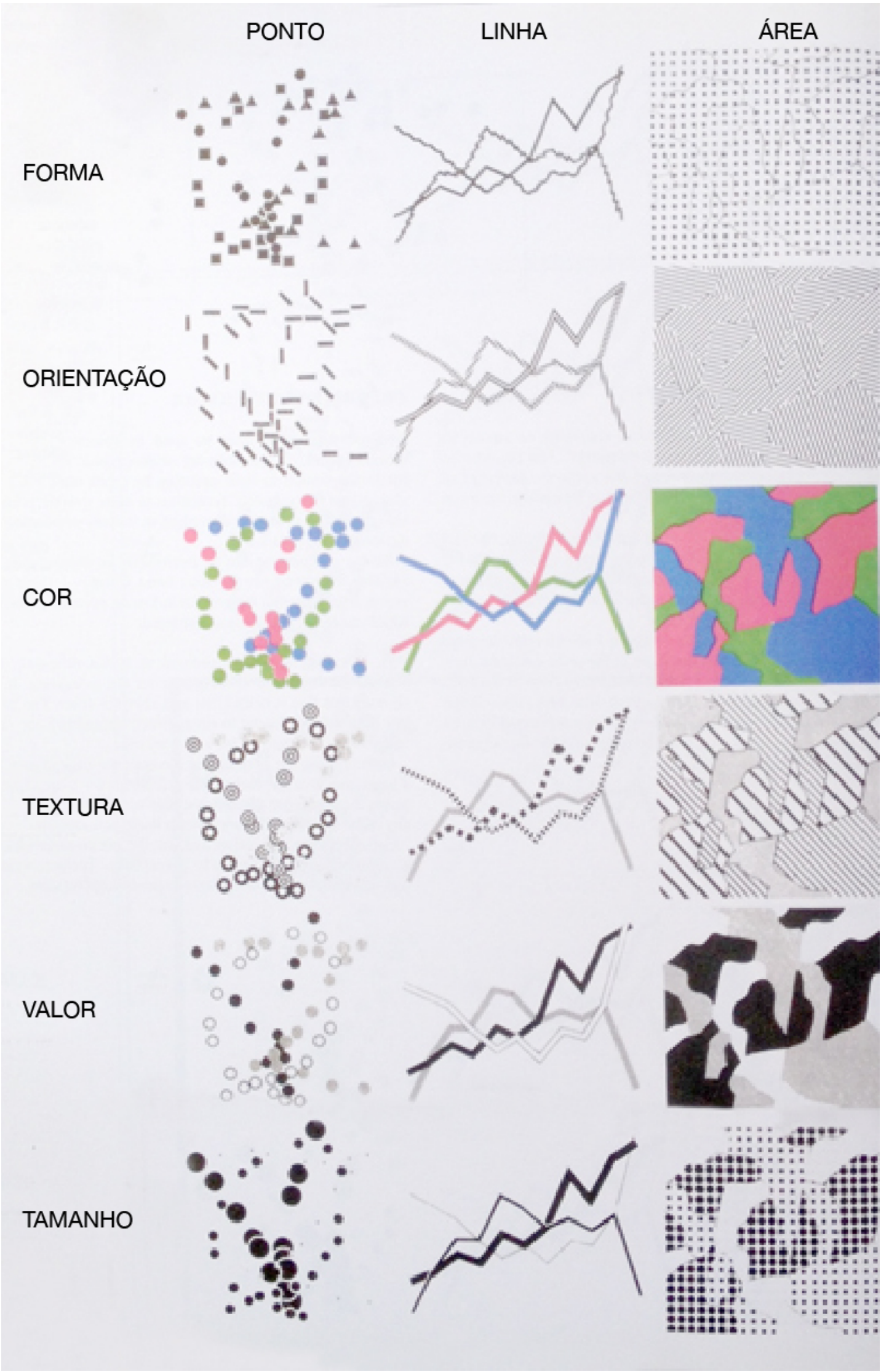

Figura 5 - Modos de implantação e variáveis visuais. Fonte: Bertin, 2010, p. 68. 
Quando Bertin, no final dos anos 60, sistematizou a Neográfica ou Semiologia Gráfica, ele o fez considerando as possibilidades de representação no suporte plano e estático. Quando, porém, passamos a analisar uma visualização da informação no suporte digital, outras variáveis entram em prática. A interface interativa permite que relações entre dados possam ser evidenciadas também por meio de recursos como, por exemplo, botões manipulados pelos usuários.

\subsubsection{Tornando a realidade visível e tangível}

Para Costa (1998, p. 7) as imagens que compõem o mundo visualizado, ou tornado visível, não são apenas representações visuais de estímulos reais do entorno e análogas a ele - imagens figurativas -, mas também outros sistemas sígnicos com base em abstrações e simplificações - visualizações científicas, como imagens endoscópicas do corpo humano, e esquemas informativos, como redes, diagramas e mapas. Visualizar significa, portanto, para produtor e consumidor da informação, respectivamente, o processo de codificação e decodificação de dados abstratos, não visuais ou discretos que revelam - tornam visíveis - padrões, tendências e exceções, geralmente invisíveis em um primeiro momento, com o objetivo de facilitar e aumentar a compreensão de determinado fenômeno.

Uma imagem é, para a Filosofia, consciência de um objeto ausente ou inexistente e, para a Psicologia, representação construída à margem dos correspondentes estímulos sensoriais (DÜRSTELER, 2003, p. 21). Para nós, a imagem visualizada é uma construção cognitiva e, como tal, se estende à representação do conhecimento, que é a apreensão intelectual das coisas. Compreender, acima de tudo, significa interiorizar. De forma semelhante Card, Mackinlay e Shneiderman afirmam que “[...] o propósito da visualização é produzir insights, não imagens" (CARD, MACKINLAY, SHNEIDERMAN, 1999, p. 6). É nesse sentido que ver é diferente de visualizar. Enquanto a primeira ação traduz-se em atividade perceptiva - respostas aos estímulos sensoriais -, a segunda corresponde à ação cognitiva, processo de raciocínio e conhecimento: 
formação dos símbolos e elementos que compõem a imagem mental (DÜRESTELER, 2003, p. 21).

Os termos ver e visualizar são utilizados, segundo o senso comum, de forma aleatória, o que justifica a confusão conceitual a seu respeito. Quando alguém diz veja bem ou pergunta viu? muitas vezes está utilizando o termo ver com sentido de visualizar, compreender fenômenos ou processos. As expressões, contudo, fazem sentido, pois, para a maioria de nós, ver e compreender são processos intrinsecamente ligados. A visão não é somente o mais rápido e detalhado portal sensorial; é também o mais intimamente ligado à cognição humana. Ver e pensar constroem, juntos, o sentido de muitos fenômenos do mundo:

Por que deveríamos nos interessar pela visualização? Porque o sistema visual humano está constantemente buscando padrões com imensa agilidade e sutileza. O olho e o córtex visual do cérebro formam um massivo processador paralelo que constitui o canal com maior cobertura de banda para a cognição humana. Nos mais altos níveis de processamento, percepção e cognição tornam-se extremamente interligados, o que é a razão para as palavras "compreender" e "ver" serem sinônimas. (WARE, 2004 p. xxi).

Embora estejamos interessados em tratar justamente das modalidades visuais que possibilitam e ampliam a cognição, cabe observar que outros sentidos perceptivos, como audição e paladar, também geram significados. É possível, portanto, visualizar a informação por meio de outros sentidos, e não somente pela visão, ainda que essa constitua o estímulo sensorial capaz de captar mais dados por unidade de tempo.

Mapeamento seria talvez um termo menos ambíguo para designar processos que organizam, codificam e implantam representações com objetivos de facilitar a compreensão. Mapear não consiste em retratar a realidade mimeticamente, mas sim em revelar realidades desconhecidas Os atos do mapeamento consistem em visualizar, conceituar, registrar, representar e criar espaços graficamente. Mas não espaços físicos e sim espaços informativos, que estruturam dados em formas de textos, vídeos, áudios e, finalmente, esquemas. Portanto, visualização da informação requer, primeiramente, a estruturação de uma massa de dados e, em seguida, a tradução visual, o tratamento gráfico. 
Tornar a realidade visível e tangível, por meio da visualização da informação, pode interessar todas as áreas do conhecimento. $\mathrm{Na}$ verdade, exemplos mais contundentes e expressivos do uso da visualização da informação para produzir conhecimento são justamente aqueles que ultrapassam limites do Design e da Comunicação e atingem atividades e saberes não tradicionalmente habituados a pensar por meio da Comunicação Visual. Nesse ponto reside a grande contribuição social desse processo interdisciplinar. Observamos um movimento em curso no qual os produtos visuais vão além de artefatos digitais, constituindo-se como práticas culturais que envolvem vários campos do conhecimento, com foco direcionado, na sociedade da informação, para mapear e dar sentido às informações, em novos formatos e segundo lógicas interativas. O caso a seguir ilustra o uso exemplar da visualização da informação em situação não convencional.

Em fevereiro de 2006, Hans Rosling - médico, estatístico e professor de Saúde Internacional no Karolinska Institute (Suécia) - proferiu uma conferência no TED ${ }^{16}$ que se torno referência no uso da visualização para aumentar a visibilidade $\mathrm{e}$ compreensão de temas de importância global. Na apresentação, intitulada The best stats you've ever $\operatorname{seen}^{17}$ (As melhors estatísticas que você já viu), de aproximadamente 20 minutos, Rosling expõe dados estatísticos sobre saúde pública e desenvolvimento mundial de forma visual e inspiradora. Na Figura 6 é possível notar a dinâmica do apresentador e o conteúdo visualmente estruturado. Rosling relaciona dados de saúde pública e dados de desenvolvimento mundial ao longo dos anos por meio de um gráfico de dispersão ${ }^{18}$ que conjuga renda per capita (eixo X), expectativa de vida (eixo Y), países (círculos) e tamanho da população dos países (área do círculo) e tempo (animação em vídeo). No frame mais acima da Figura 6, observamos os dados representados em um primeiro momento, 1810, quando todos os países se concentram no canto inferior esquerdo do gráfico de dispersão, o que significa alto índice de pobreza e insalubridade. No segundo

\footnotetext{
${ }^{16}$ TED é a abreviação de Technology, Entertainment, Design, conferência criada em 1984 que reúne uma série de apresentações mundiais e locais sobre temáticas e ideias inovadoras.

${ }_{17}$ A apresentação está disponível em <http://www.ted.com/talks/hans_rosling_shows_the_best_stats_you_ve _ever_seen.html>. Acesso em mar. 2013. A repercussão da apresentação foi tamanha, que motivou a produção de um documentário intitulado The Joy of Stats (A alegria da estatística) divulgado em 2010 pelo canal BBC de televisão.

${ }^{18}$ Gráfico de dispersão, ou gráfico relacional, é uma representação gráfica de duas ou mais variáveis que se enquadra na modalidade de visualização da informação e "[...] apresenta evidências sobre causa e efeito, ilustrando como uma variável afeta outra" (TUFTE, 1983, p. 82).
} 
frame da Figura 6, mais abaixo, observamos o cenário em 2009, quando Rosling visualiza uma tendência para a convergência dos países em direção à riqueza e à salubridade.
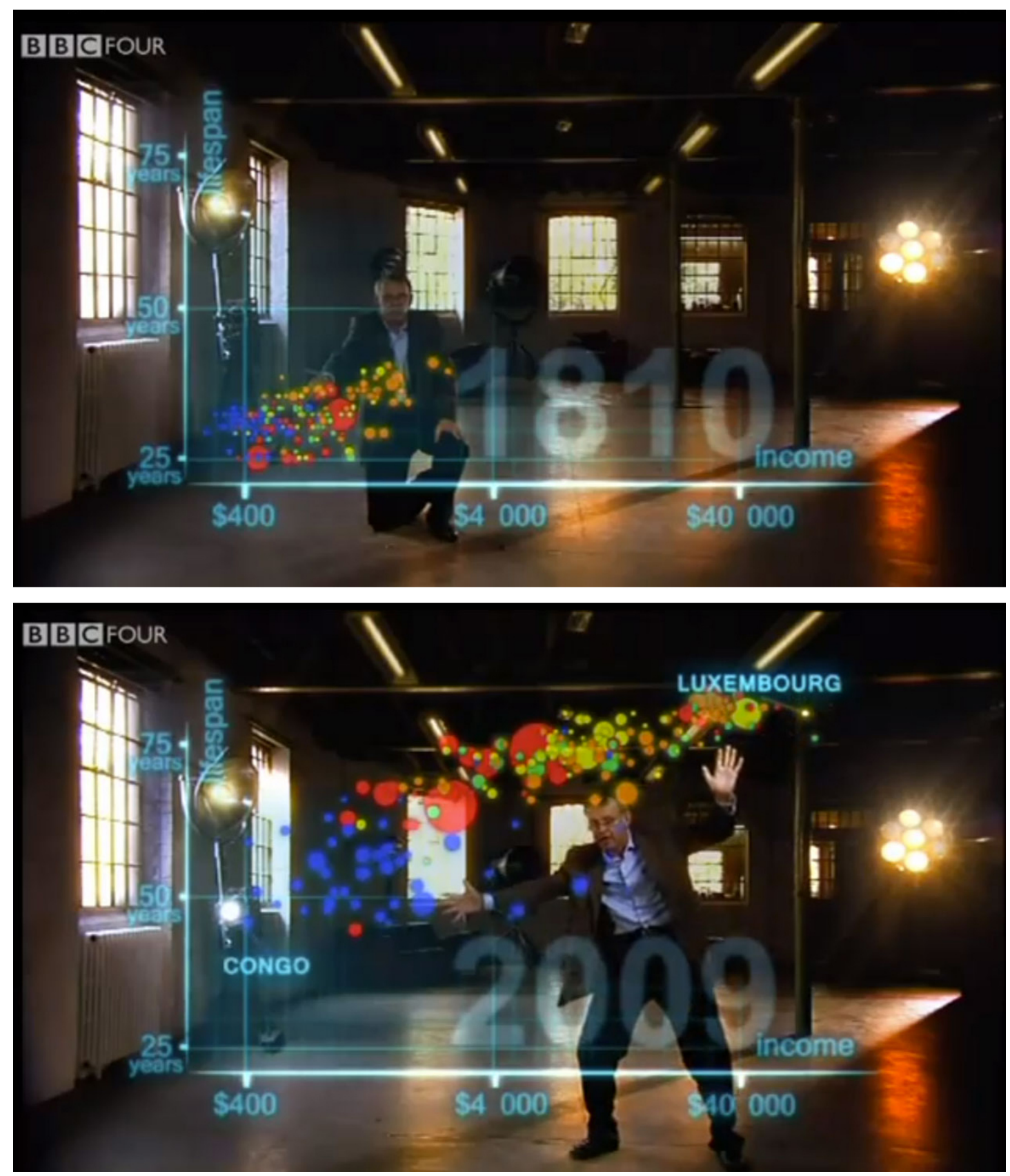

Figura 6 - The best stats you've ever seen. Fonte: Arquivo pessoal utilizando imagens do vídeo original.

Além de desmitificar alguns aspectos do senso comuns sobre o tema a partir de dados que revelam tendências e relações, a apresentação contribui para reforçar o papel que Design e Estatística desempenham nas mais variadas atividades e competências humanas. Kosara (2014) destaca que a apresentação de Rosling ilustra, perfeitamente, como a visualização da informação pode ser utilizada pelos 
comunicadores para explanar por meio de dados uma versão sobre realidade que, no momento em que é narrada, se expanda em um mundo de descobertas e de sensemaking para o usuário:

Muitas vezes, é importante levar as pessoas à descoberta. Rosling faz isso, para que as pessoas questionem suas ideias preconcebidas sobre fatos e prestem atenção. Jornalistas fazem o mesmo quando tentam noticiar algo que desejam que os leitores conheçam, mas a respeito do que talvez eles não tenham nenhuma informação prévia (KOSARA, 2014).

Para Rosling “[...] a Estatística não pertence somente ao domínio da especialização, mas também às mais simples e inspiradoras atividades do dia a dia, com potencial de transformar a vida dos cidadãos "(ROSLING apud CAIRO, 2012, p. 309). Poderíamos dizer o mesmo a respeito dos potenciais do Design e dos produtos e processos dele derivados. 


\section{Jornalismo on-line e representação visual}

\subsection{ESTILO JORNALÍSTICO}

O Jornalismo é percebido, de forma geral, como prática profissional de pesquisa, verificação, organização e divulgação de conteúdos socialmente relevantes, de modo a fornecer "[...] informação independente, confiável, precisa e compreensível, elementos importantes para que o cidadão seja livre" (KOVACK; ROSENSTIEL, 2003, p. 20). Para Pasquall (2005, p. 25), no entanto, o fato de o Jornalismo ser, historicamente, calcado no ato de informar ${ }^{1}$ implica prática comunicativa estabelecida, predominantemente, 1) pela relação de causa e efeito, que torna a mensagem informativa parcial ou totalmente inquestionável; 2) em um canal de mão única, cujo polo transmissor institucionalizado transfere mensagens informativas para o polo receptor passivo e 3) segundo lógicas midiatizadas, isto é, subordinadas às relações e intersecções entre processos sociais e processos comunicativos. Para as teorias estruturalistas e interacionistas do Jornalismo, a produção da notícia é construção social (TRAQUINA, 2005). A notícia depende de fatores apontados pelas hipóteses de newsmaking, isto é, critérios de “[...] noticiabilidade, ${ }^{2}$ a sistematização do trabalho jornalístico através da divisão de tarefas e a aplicação dos valores-notícia ${ }^{3}$ [...]" (SCHWINGEL, 2012, p. 79). Dessa forma, o Jornalismo designaria mais ação de controle do que, propriamente, de libertação.

Em uma tentativa de destacar princípios do Jornalismo, podemos dizer que a disciplina polarizou-se em duas frentes: dos estudos funcionalistas e da teoria crítica. A primeira, norte-americana, especializou-se no estudo dos efeitos com enfoques “[...] relacionados com a exploração econômica (publicidade), a militar e a política

\footnotetext{
${ }^{1} \mathrm{O}$ verbo informar é utilizado por Pasquall no sentido de "[...] interpenetração ou imposição de uma forma, ideia ou princípio, com ou em matéria, que assim se tornava 'in-formada' ou 'formada”" (PASQUALL, 2005 p. 25).

${ }^{2} \mathrm{O}$ conceito de noticiabilidade refere-se à sistematização de fatores que fazem determinado acontecimento ser considerado, ou não, notícia.

${ }^{3}$ Valores-notícias compõem valores subjetivos que determinam a importância de um fato ou acontecimento. Traquina (2005) sistematiza valores-notícias em três classes: critérios substantivos, critérios contextuais e critérios de construção.
} 
(propaganda) e os resultados da investigação" (KUNCZIK, 1997, p. 19). A segunda denunciou manipulação do público, intencionada e objetivada pela indústria cultural (WOLF, 2010, p. 82). Das duas abordagens emergem problematizações a respeito da objetividade, imparcialidade e precisão, ${ }^{4}$ princípios e valores por meio dos quais o Jornalismo, tradicionalmente, busca construir um estilo de comunicação que assegure legitimidade e relação de confiança com o leitor.

Segundo Keeble (1994, p. 86), a linguagem jornalística não é natural, mas produto de séculos de evolução linguística que apresenta estrutura e vocabulário próprios. A teoria da pirâmide invertida, extensamente estudada nos cursos de Jornalismo, preconiza que em um texto jornalístico de intencionalidade informativa, as informações sejam estruturadas e apresentadas por ordem de importância decrescente (RABAÇA; BARBOSA, 1987, p. 461). Dessa forma, fatos principais - o lide jornalístico - devem abrir a matéria, seguidos de fatos de importância intermediária; informações que, pelos critérios jornalísticos, são consideradas prescindíveis, devem ser deixadas para o final.

De acordo com Lage, a comunicação jornalística é, por definição, referencial, isto é, “[...] fala de algo no mundo, exterior ao emissor, ao receptor e ao processo de comunicação em si” (LAGE, 1986, p. 39). Paralelamente, estudos contemporâneos sobre Jornalismo apontam que a linguagem jornalística não possui apenas função referencial, mas assume também função pragmática uma vez que contextualiza fatos e agentes, buscando categorizar, descrever e manifestar estruturas dos acontecimentos do mundo, segundo hierarquias e valores, que podem ser arquitetados conscientemente, ou não, pelos mediadores.

\footnotetext{
${ }^{4}$ De forma geral, empresas de comunicação, no Brasil e no mundo, incorporaram manuais de estilo como guias de produção jornalísticos. As orientações contidas nesses manuais - como Manual de redação e estilo de O Estado de S. Paulo e Manual de estilo da Editora Abril - podem ser encaminhadas para quatro instruções principais: objetividade, precisão, concisão e clareza.
} 


\subsubsection{Características do jornalismo on-line ${ }^{5}$}

Em meados dos anos 90, quando computadores domésticos e internet comercial começavam a difundir-se nas casas e nos escritórios, Schudson (2003) anteviu que o Jornalismo seria impactado por essas novas tecnologias da informação e comunicação (TICs). No mundo previsto e imaginado pelo autor, agentes sociais (organizações, entidades civis e cidadãos) tornam-se capazes de buscar, produzir, consumir e redistribuir informações por meio de plataformas de circulação e produção em rede, conectadas e abertas a muitos interagentes. ${ }^{6}$ No entanto, se para alguns estudiosos a emergência dessas tecnologias poderia resultar no fim do Jornalismo, Schudson preferiu apostar que, de certa forma, atividades relacionadas à área seriam reinventadas. Paralelamente, também a relevância e pertinência dos mediadores comunicacionais, assim como os reflexos de suas ações de seleção e organização jornalísticas, seriam, mais à frente, destacadas diante da saturação e heterogeneidade informativa:

A ideia sugerida por Pierre Lévy (1999:188) de um possível desaparecimento do Jornalismo (ou pelo menos dos Jornalistas enquanto intermediários), em função do desenvolvimento da Internet, parece-nos, cada vez mais, uma simplificação descabida. Sugerimos, ao contrário, que com o crescimento da massa de informação disponível aos cidadãos, torna-se ainda mais crucial o papel desempenhado por profissionais que exercem funções de "filtragem e ordenamento" desse material, seja a nível jornalístico, acadêmico, lúdico, etc. (PALACIOS, 2003, p. 5).

A plataforma de circulação na internet e os avanços das tecnologias digitais e ferramentas para publicação na rede delineiam, por um lado, proliferações de mídias autônomas e alternativas, como blogs e sites pessoais que caracterizam a cultura

\footnotetext{
${ }^{5}$ Há uma discussão, academicamente estabelecida, em torno da denominação da prática jornalística exercida na internet, a saber: jornalismo em rede, jornalismo eletrônico, jornalismo multimídia, jornalismo digital, ciberjornalismo, webjornalismo e, finalmente, jornalismo on-line, expressão que adotaremos neste trabalho. Para Schwingel (2012, p. 33), a sistematização acerca dos termos é esforço de precisão conceitual, e a escolha de jornalismo on-line enfatiza nossa perspectiva frente às práticas exercidas nesse novo contexto produtivo. Nesse sentido, on-line caracteriza um tipo de jornalismo desenvolvido com tecnologias de transmissão em rede e em tempo real, reforçando seu caráter hipertextual, interativo e de circulação expandida.

${ }^{6}$ Algumas das transformações anunciadas por Schudson (2003) podem ser aproximadas do que hoje chamamos de Web 3.0. Para o exercício jornalístico, Web 3.0 caracteriza cenários de produção e consumo de conteúdos marcados pelo desenvolvimento da Web Semântica (que já caracterizava a chamada Web 2.0), pela introdução do uso de algoritmos, aplicativos (apps), base de dados e, principalmente, pela emergência de lógicas interativas e dialógicas, que conferem ao polo receptor um papel mais ativo.
} 
participativa (JENKINS, 2011), e, por outro lado, transformações em organizações tradicionais de comunicação que buscam adaptar seus processos de produção a um novo tipo de Jornalismo, isto é, não apenas um novo formato, mas sim um produto discursivo distinto em um novo suporte (SCHWINGEL, 2012, p. 31). A era digital carrega consigo novos aspectos e condições para as formas como empresas jornalísticas constroem socialmente a realidade:

Ao lado de audiências cada vez mais "nômades" e móveis, ao sabor de escolhas e possibilidades individuais mais autônomas e fragmentadas, o jornalismo vem enfrentando mudanças no seu modelo de negócios, na gestão das empresas, nos modos de engajamento de seus profissionais e em função das inovações tecnológicas, que geram alterações significativas nos processos de produção, edição, arquivo, distribuição e disseminação das notícias (LEAL, 2011, p. 104).

Neste trabalho direcionamos nosso olhar para mudanças ocorridas no âmbito das organizações jornalísticas e, mais especificamente, para um inovador dispositivo midiático que delas insurge.

Palacios (2003, p. 3-4), à luz de sistematizações realizadas anteriormente, identifica seis elementos diferenciadores e potenciais que caracterizam produtos e sistemas de produção no jornalismo on-line:

- multimidialidade/convergência: qualidades que caracterizam a conjugação de formatos de mídias tradicionais (imagem, texto, som, etc.) na narração do fato jornalístico e sua posterior circulação em múltiplas plataformas e suportes, descrevendo uma situação de complementaridade;

- interatividade: qualidade que permite aos usuários tornar-se mais diretamente ativos no processo jornalístico. Relações interativas podem ser: 1) com a máquina; 2) com a própria publicação, por meio do hipertexto e 3) com outras pessoas autor(es) ou outro(s) leitor(es) - por meio da máquina;

- hipertextualidade: qualidade que permite interconexões entre textos, compreendidos como blocos de informação, por meio de hyperlinks;

- customização do conteúdo/personalização: qualidades que caracterizam a possibilidade de o usuário configurar produtos jornalísticos - o conteúdo e/ou sua configuração visual - a partir de interesses individuais; 
- memória: qualidade que potencializa efeitos de registro e acúmulo de informações que poderão ser, posteriormente, acessadas tanto por consumidores como produtores de conteúdo;

- atualização contínua/instantaneidade: qualidades que caracterizam a possibilidade dos produtos jornalísticos serem continuadamente atualizados pelos produtores da informação, permitindo acompanhamento e monitoramento de assuntos de maior interesse.

A característica interatividade possibilita inserção do usuário de forma mais ativa e substancial no processo jornalístico, podendo expandir-se, em última instância, para ações participativas que sobrepõem os polos de produção (emissão) e consumo (recepção) comunicativos. A interatividade, junto às outras características do jornalismo on-line, ressignifica o fazer jornalístico e incute transformações sobre o papel social e mediador do jornalista, o processo de produção jornalístico (produção-circulação-consumo), os critérios de construção da notícia e, finalmente, o empoderamento do usuário.

Potencialidades oferecidas pela internet e pelos recursos digitais ao Jornalismo não se traduzem, necessariamente, em aspectos efetivamente explorados em todos os produtos midiáticos decorrentes de sítios jornalísticos, ${ }^{7}$ seja por razões técnicas, conservadorismo, adequação ou aceitação do público consumidor. Os novos meios de comunicação que surgem de certa forma copiam meios anteriores. Diante dessa perspectiva, produtos midiáticos elaborados no jornalismo on-line podem ser situados em gerações. De acordo com uma primeira classificação desenvolvida pelo GJOL, ${ }^{8}$ produtos elaborados pelo jornalismo on-line podem ser situados como:

[...] 1) a transposição dos veículos impressos; 2) a metáfora do impresso (quando os produtos começam a apresentar serviços e informações específicos para a internet, porém não se distanciam da estrutura e da representação do jornal ou da revista impressos) e 3) o jornalismo de terceira geração

\footnotetext{
${ }^{7}$ Utilizamos a expressão sítio jornalístico para designar publicações jornalísticas analisadas neste trabalho em detrimento da expressão portal jornalístico, pois este último, segundo Ferrari (2004, p. 30), caracteriza tipos de publicação que reúnem, além de conteúdos jornalísticos, elementos de entretenimento e serviço, como ferramentas de busca, comércio eletrônico, previsão do tempo, e-mail gratuito, discos virtuais, sítios pessoais e jogos on-line. São exemplos de portais jornalísticos brasileiros: Terra, Uol e Ig.

${ }^{8}$ O GJOL, Grupo de Pesquisa em Jornalismo On-line, pertence à Faculdade de Comunicação da Universidade Federal da Bahia e, desde 1995, desenvolve pesquisas no campo conduzidas pelos professores doutores Marcos Palacios e Elias Machado.
} 
(quando os produtos e serviços são propostos de forma específica para web) (SCHWINGEL, 2012, p. 44).

Nos últimos anos, a sistematização em três gerações tem sido problematizada. Barbosa (2007), em sua tese de doutorado, propõe avanços para uma quarta geração de produtos midiáticos e sistemas de produção desenvolvidos pelo jornalismo on-line, caracterizada pela utilização de base de dados inteligentes e dinâmicas e sistemas automatizados para processos de produção jornalísticos. Em consonância com a autora, Schwingel (2012, p. 46) denomina essa quarta geração experiências ciberjornalísticas e destaca a incorporação do usuário no processo de produção por meio de mecanismos que se aproximam de questões do jornalismo colaborativo.

É difícil delimitar, em termos temporais, gerações de produtos e sistemas de produção jornalísticos na plataforma on-line, pois elas coexistem no atual cenário produtivo. No entanto, podemos exemplificar gerações por meio de produtos midiáticos concretos e atuais (Quadro 7):

Quadro 7 - Gerações e produtos do jornalismo on-line

\begin{tabular}{|c|c|c|}
\hline Geração & Característica & Exemplo \\
\hline 1a Geração $^{\text {a }}$ & $\begin{array}{l}\text { Edições digitais de } \\
\text { jornais impressos. } \\
\text { Os produtos são } \\
\text { praticamente } \\
\text { transpostos do } \\
\text { impresso para a web. } \\
\text { O processo de produção } \\
\text { é o mesmo das } \\
\text { mídias impressas }\end{array}$ & 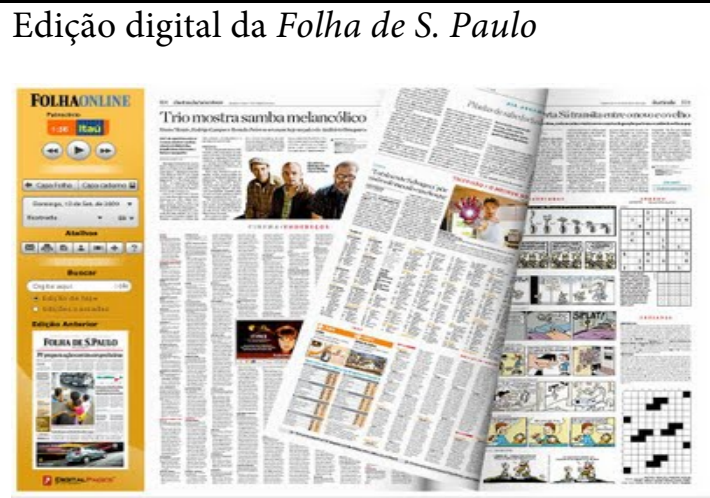 \\
\hline 2- Geração & $\begin{array}{l}\text { Sítios jornalísticos. } \\
\text { Apresentam algumas } \\
\text { características da plataforma } \\
\text { digital e on-line como } \\
\text { personalização do } \\
\text { conteúdo e interatividade. } \\
\text { No entanto, produtos } \\
\text { e sistemas de produção } \\
\text { conservam a lógica } \\
\text { metafórica das }\end{array}$ & Sítio jornalístico do O Estado de S. Paulo \\
\hline
\end{tabular}




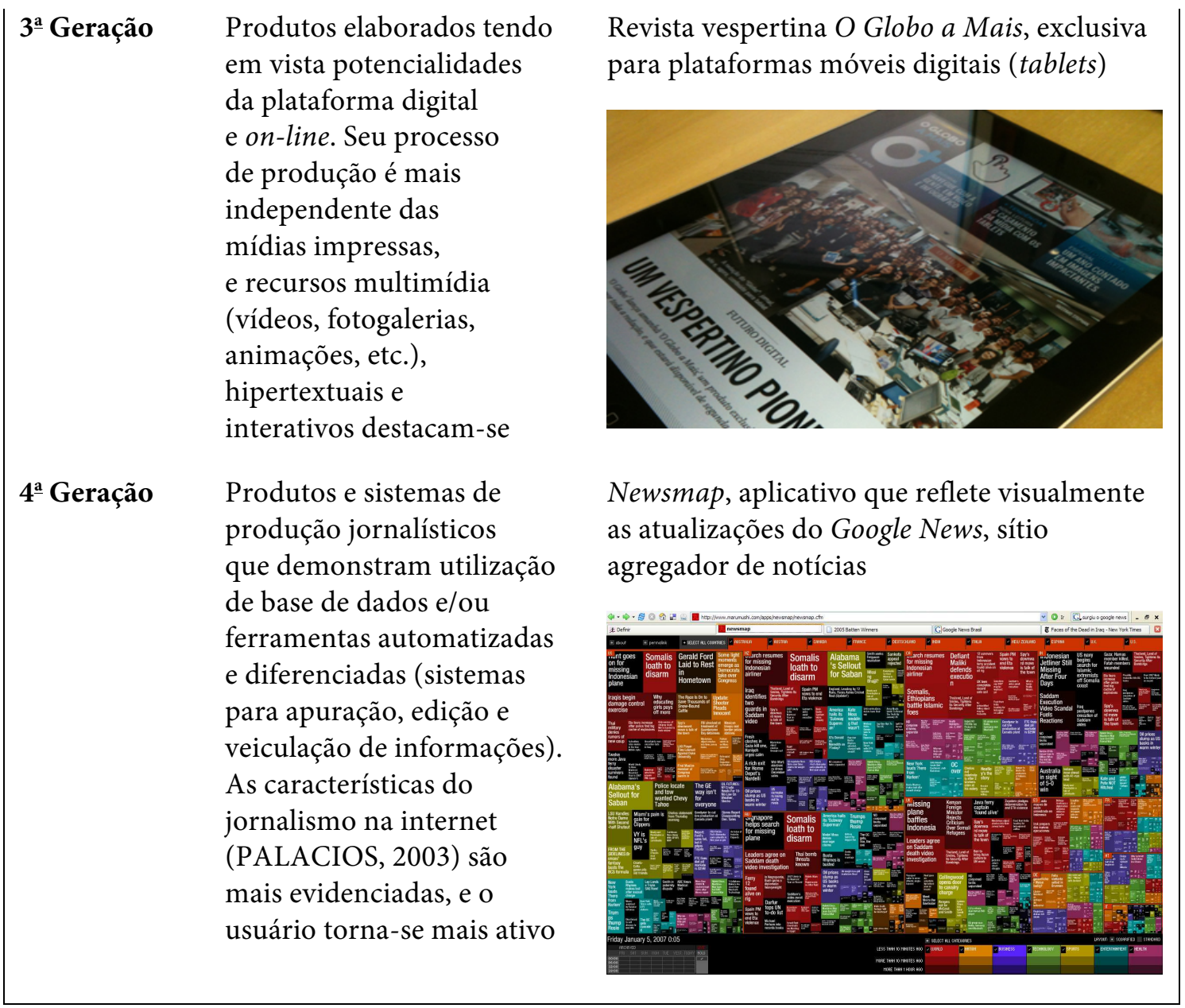

Fonte: elaboração própria baseada em Schwingel (2012).

O aplicativo Newsmap é exemplo de produto midiático que opera, automaticamente, por meio de algoritmos que realizam varreduras de informações jornalísticas na web. Sua estrutura e organização visual se baseiam em técnicas da visualização da informação, de modo que sua interface agrupa, hierarquiza e visualiza informações por categorias temáticas, geográficas e quantitativas. Veículos mainstream, isto é, empresas jornalísticas propriamente ditas, como The New York Times, The Guardian, Folha de S. Paulo e O Estado de S. Paulo - veículos que compõem o corpus deste trabalho - também apresentam, em seus sítios, produtos e sistemas de produção pontuais que se enquadram na quarta geração do jornalismo on-line. Nosso objeto de estudo, o infovis, apresenta lógicas interativas para exploração do conteúdo, por parte do usuário, ao mesmo tempo em que manifesta, por meio de suas interfaces, elementos de tratamento jornalístico e escolhas de design que delineiam ações mediadoras, situando-se como produto midiático entre a terceira e a quarta geração do jornalismo on-line. 


\subsection{REPRESENTAÇÃO VISUAL NO JORNALISMO}

Jornalismo visual pode ser compreendido em três dimensões: “[...] a prática profissional e seus produtos, a formação específica do profissional com repertório e habilidades compatíveis com o jornalismo e com o design, e a da crítica e pesquisa (GUIMARÃES, 2012, p. 7). Acerca das práticas e produtos desenvolvidos, o jornalismo visual abrange diversas instâncias em que conhecimentos da Comunicação Visual e do Jornalismo encontram-se para criar formas adequadas de representação do conteúdo informativo, resultando, na maioria das vezes, em manifestações texto-visuais como, por exemplo, charges, ilustrações, fotografias, infográficos, e, em um nível mais amplo, no desenvolvimento de projetos gráficos jornalísticos que implicam escolhas de diagramação (hierarquia e tipografia) adaptadas ao suporte de determinada mídia impressa ou digital, e suas variações de formato - e a decisões editoriais.

Guimarães (2012, p. 2) afirma que a prática do jornalismo visual existe desde o surgimento do próprio Jornalismo, assim como Emery (1965, p. 16) defende que “[...] ilustrações eram comuns muito antes do aparecimento do jornal”. No entanto, inicialmente, os responsáveis pelas atividades jornalísticas eram homens em suas condições de apuradores e escritores da notícia. Não havia uma sistematização da atividade profissional, o processo de reprodução de imagens era lento, e a linguagem escrita predominava sobre a linguagem visual. A capa da primeira edição do jornal inglês The Daily Courant, de março de 1702, composta inteiramente por textos (EMERY, 1965, p. 32), ilustra o domínio das formas linguísticas. Se, por um lado, imagens eram pouco exploradas no início da imprensa, por outro lado, avanços na prática do jornalismo visual podem ser compreendidos em termos dos avanços tecnológicos (técnicas de reprodução de imagem, técnicas de impressão, desenvolvimento da informática, etc.) e da profissionalização da atividade jornalística, sem, no entanto, perder sua ligação com tradições da escrita e da imagem. Embora não tenha sido uma transformação instantânea, o Jornalismo, aos poucos, aliou-se fortemente a determinados recursos visuais - como fotografia, ilustração e infográfico com o objetivo de dar respaldo visual à realidade dos fatos noticiados. A introdução da 
fotografia no Jornalismo, no final do século XIX, talvez tenha significado, em termos de visualidade e veracidade, ${ }^{9}$ o maior marco do jornalismo visual até o momento:

Há muito tempo os jornais utilizam fotografias como evidência de autenticidade. Da mesma forma que imagens da televisão, essas fotografias constituem-se numa contribuição poderosa ao que o crítico Roland Barthes (1915-1980) chamou o "efeito de realidade" (BURKE, 2004, p. 26).

Todavia, em tempos de discursos inflamados e apocalíticos sobre o futuro do Jornalismo, sobretudo na mídia impressa, Javier Errea, professor da Universidade de Navarra, Espanha, e ex-presidente do SND-E (Society for News Design) preconizou que a crise do Jornalismo é, na verdade, crise da imprensa escrita e defendeu que somente a infografia salvaria os jornais:

Por que digo isto? Porque uma infografia oferece as
ferramentas para acabar com a fórmula clássica de fazer
Jornalismo: Informação $=$ Título + Texto + Foto. Esta
fórmula serviu durante anos. [...] O que, sem dúvida, acabou
por uniformizar a maneira de contar a realidade,
submetendo-a às estreitas margens da narrativa textual
(ERREA, 2008 apud TEIXEIRA, 2010, p. 29).

Como afirma Guimarães (2012, p 2), jornalismo visual é mais amplo do que desenhos de infográficos, porém é nesse produto midiático que, de fato, ocorre a conjugação indissociável de texto, imagem e elementos esquematizadores. A infografia pode proporcionar, aos leitores, um modelo comunicacional atraente, informativo e interativo e, às organizações jornalísticas, formatos e linguagens que reconfiguram seus processos de produção noticiosa.

A pesquisa Eyetracking, promovida pelo The Poynter Institute, em 2007, investigou como se comporta a leitura do leitor. Através de duas pequenas câmeras acopladas a uma espécie de óculos oferecidos aos leitores participantes da pesquisa, movimento e direcionamento de seus olhares foram monitorados durante leituras em plataformas impressas e on-line. O resultado da pesquisa apontou que manchetes e imagens são os primeiros elementos visualizados na página e são também pontos de atração, aos quais o olhar se direciona. Quando elementos visuais e verbais são

\footnotetext{
${ }^{9}$ Atualmente, o valor documental e referencial da fotojornalismo é problematizado pelas mesmas questões que atingem, amplamente, o Jornalismo - escolha do objeto a ser retratado e critérios editoriais (no caso da fotografia, enquadramento, tratamento visual, etc.) - e implicam decisões midiatizadas.
} 
blocados e não associados, o texto tradicional tende a ser ignorado. Por sua vez, se elementos visuais estiverem integrados ao texto, este último receberá mais fixações do olhar do leitor. Na Figura 7, o direcionamento do olhar de um leitor é representado por uma linha vermelha diante de duas páginas com diferentes diagramações:

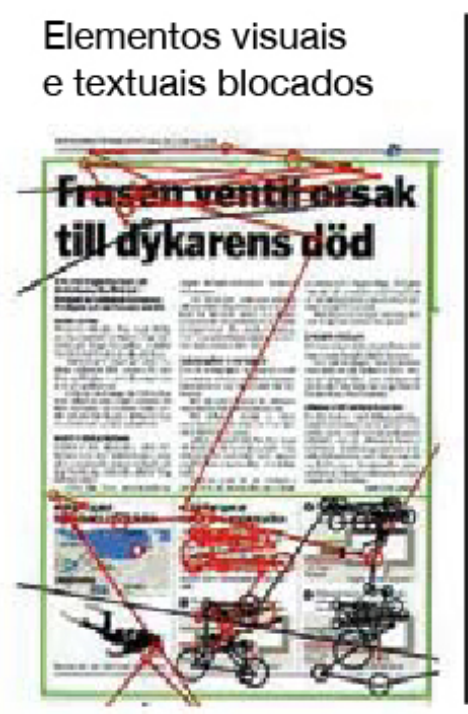

Elementos visuais e textuais integrados
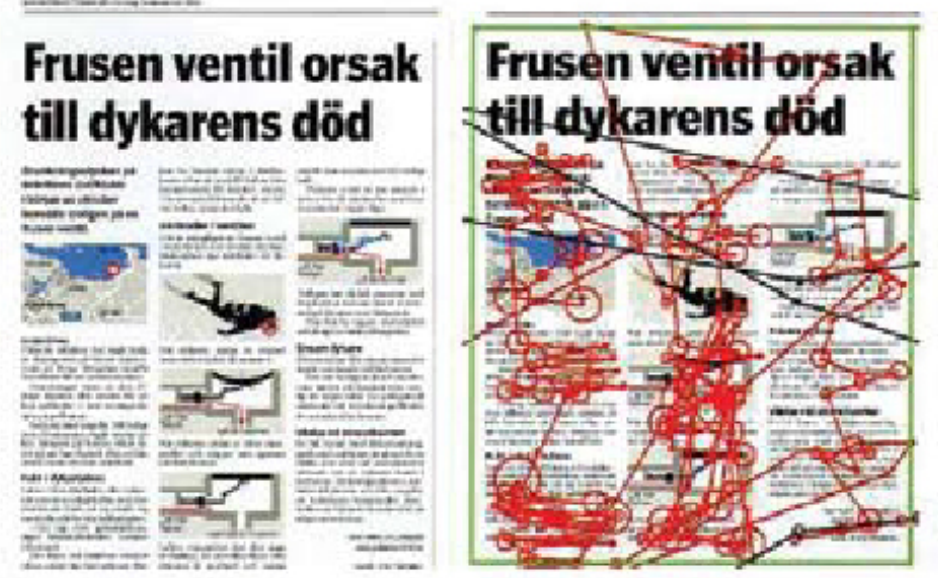

Figura 7 - Pesquisa Eyetracking. Fonte: elaboração própria adaptada de Silveira, 2010, p. 54.

Com base nos resultados dessa pesquisa, Kanno (2008) elencou formatos nos quais leitores, tendencialmente, mais fixam o olhar. No topo da lista, encontram-se os infográficos, que chamaram a atenção de $80 \%$ dos leitores observados nos testes. Em último lugar, os textos foram fixados pelo olhar de somente $25 \%$ dos leitores.

\subsubsection{Infografia jornalística}

A prática rotineira da infografia em redações constitui atividade profissional recente e, talvez por esse motivo, seus reflexos em discussões acadêmicas sejam escassos e, algumas vezes, incongruentes frente à outras linguagens, verbais e visuais, mais difundidas na imprensa, como gêneros jornalísticos textuais e fotográficos. Não é nosso objetivo reconstituir o histórico da pesquisa acadêmica ou do exercício profissional a respeito da infografia. Nem mesmo discutir, profundamente, suas definições, extensões de uso e tipologias. Sobre esses aspectos, já existe considerável bibliografia especializada, de que destacamos: Cairo (2008; 2013), Cordeiro (2013), Kanno e Brandão (1998), Lima 
(2009), Lucas (2010), Moraes (1998), Pereira (2006), Ribas (2005b), Silveira (2010), Teixeira (2010). Todavia, diante de panorama intrincado por divergentes abordagens, faz-se necessário rever alguns conceitos sobre infografia a fim de esclarecer de que ponto partimos para refletir sobre seu estado da arte diante da reconfiguração do exercício jornalístico no ambiente on-line contextualizado pelo excesso de dados e pelas potencialidades interativas da interface digital.

\subsubsection{Infografia: um breve apanhado histórico}

Alguns autores - Cairo (2008; 2013), Kanno e Brandão (1998), De Pablos (1999), Peltzer (1992), Sancho (2001) - remontam a história da infografia às manifestações visuais mais remotas, percorrendo diversas influências culturais, visuais e tecnológicas: da pintura das cavernas (c. 35.000 a.C.), passando pelo uso do mapas no Egito antigo, pelos avanços do sistema de escrita até a invenção do alfabeto fenício (c. 1050 a.C.), pelas ilustrações científicas de Leonardo da Vinci e Andreas Vesalius (c. 1500), gráficos de William Playfair (1786) e a cartografia temática de John Snow (1854) e Charles Joseph Minard (1869), até, finalmente, a constituição de uma prática infográfica na imprensa. ${ }^{10} \mathrm{Se}$, historicamente, essas evidências nos mostram que a infografia, de fato, possui precursores longínquos, neste momento fazemos nossa primeira delimitação de pesquisa: não pretendemos dar conta de sua amplitude, mas ater-nos especificamente ao infográfico como produto midiático restrito ao Jornalismo.

A presença de infográficos na imprensa popularizou-se somente nos anos 80, em função de três principais fatores, assim destacados por Teixeira (2010, p. 20-23): 1) informatização das redações e avanços dos recursos tecnológicos de impressão; 2) marco do diário norte-americano USA Today, jornal fundado em 1982 e calcado no uso de textos curtos e na predominância da linguagem visual e 3) cobertura da Guerra do Golfo, em 1991, que consolidou a infografia como modalidade de noticiar a informação em termos texto-visuais.

\footnotetext{
${ }^{10}$ Silveira (2010, p. 61-70), em sua dissertação de mestrado, desenvolve uma esclarecedora linha do tempo que reconstitui a história da infografia.
} 
Não há unanimidade quanto ao primeiro infográfico publicado em jornais impressos. Nem mesmo há consenso entre autores se os primeiros infográficos podem ser assim denominados, pois na época em que foram produzidos não havia termo específico para essas representações gráficas nem uma prática infográfica consolidada. ${ }^{11}$ Não obstante, para Peltzer (1992, p. 108) “[...] o primeiro gráfico ou diagrama informativo publicado num meio de comunicação" (Figura 8) foi veiculado na primeira página do jornal britânico The Times, em 7 de abril de 1806, e reconstitui o homicídio de Isaac Blight, detalhando o cenário do crime em representação gráfica semelhante à planta baixa de uma casa contendo informações sobre trajetória da bala e local onde o corpo foi encontrado.

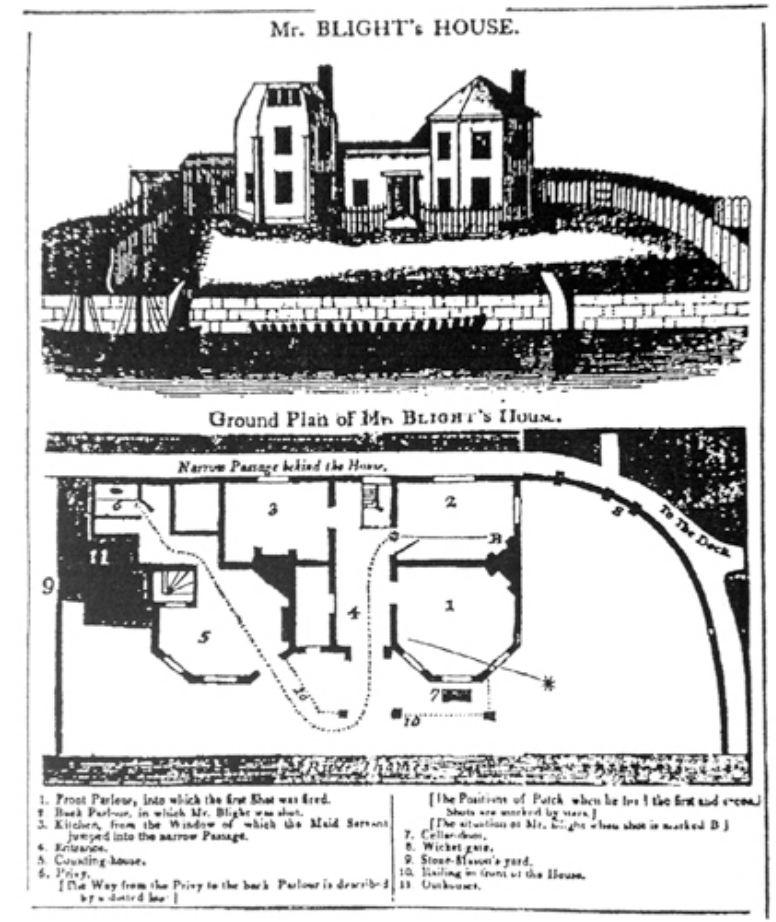

Figura 8 - Mr. Blight's House. Fonte: Peltzer, 1991, p. 108.

Para Cairo “[...] as primeiras infografias da imprensa foram mapas criados por autores anônimos nos quais se intuía uma certa falta de conhecimentos cartográficos” (CAIRO, 2008, p. 49). Dito isso, o autor apresenta um exemplo do que considera ser o primeiro infográfico jornalístico: um mapa, publicado em 22 de setembro de 1702, que demonstra a tentativa de invasão da baía de Cádiz por tropas britânicas. De Pablos (1999) ainda menciona a ilustração The Snake Device, veiculada pelo Pennsylvania

\footnotetext{
${ }^{11} \mathrm{Na}$ revisão bibliográfica encontramos diversos termos utilizados para nomear representações gráficas que seriam precursoras do infográfico, a saber: gráfico, mapa, gráfico informativo, ilustração, ilustração informativa, jornalismo pictórico, diagrama e diagrama informativo.
} 
Gazette em 9 de maio de 1754, que representa “[...] uma serpente cortada em oito partes, que seriam oito dos estados, então desunidos, dos atuais Estados Unidos de América" (DE PABLOS, 1999, p. 21).

No Brasil, o uso da infografia em redações disseminou-se mais tardiamente, a partir da década de 1990, embora seja possível identificar "[...] o uso de recursos gráficos precursores da infografia, no jornal O Estado de S. Paulo, publicado em 18 de agosto de 1909, há mais de cem anos, portanto" (TEIXEIRA, 2010, p. 24) (Figura 9):

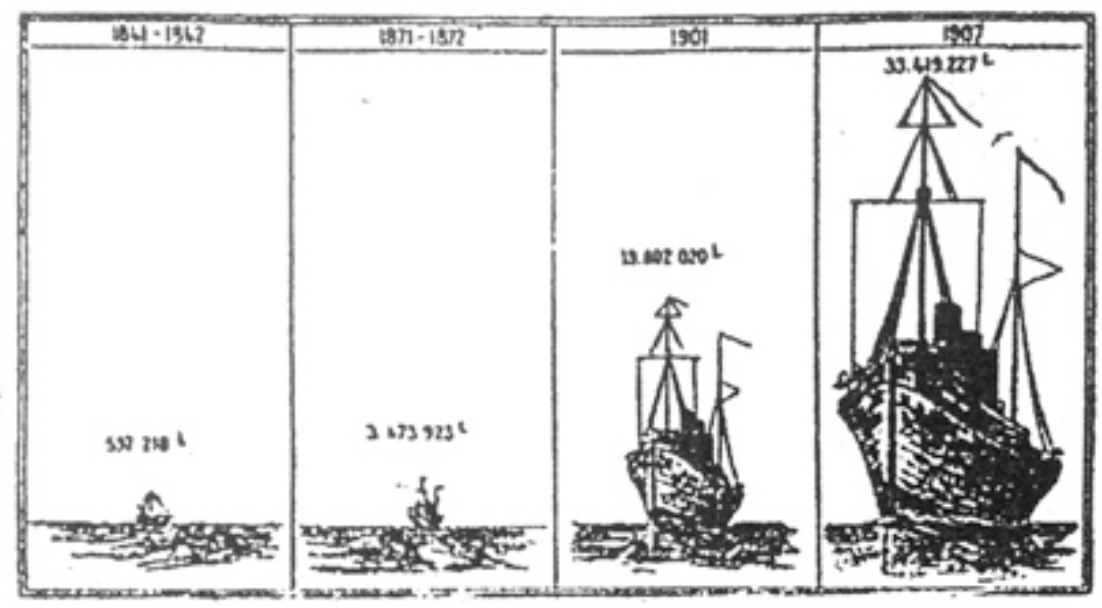

A' medida q̨uo croseo o nosso comnorcio iaternacional, augmenta fatal. nento a navegagąo inaritima. O qquadro acima mostra bom o desenvolvimento juo ella tovo 110 Brasil.

Figura 9 - A navegação brasileira. Fonte: Teixeira, 2010, p. 24.

Outro fator que possibilitou o crescimento da infografia jornalística no Brasil se constitui de reformas gráfico-editorais realizadas por muitos jornais na década de 1990 . Graças aos avanços trazidos pelas reformas, tornou-se mais comum a presença de consultorias internacionais que incentivaram a criação de departamentos próprios de infografia e ilustração em redações do país. Em 1993, foi criado o prêmio internacional Malofiej ${ }^{12}$ que, desde então, elege, anualmente, as melhores soluções infográficas publicadas no mundo. No cenário brasileiro, uma iniciativa recente é o Infolide, evento anual que acontece em São Paulo, desde 2006, e evidencia produções infográficas nacionais, reunindo especialistas, designers e jornalistas interessados no tema. $\mathrm{O}$

\footnotetext{
${ }^{12}$ Malofiej Awards, assim nomeado em homenagem a Alejandro Malofiej, cartógrafo argentino reconhecido mundialmente pelo uso pioneiro de infográficos, é apontado como o mais importante concurso mundial de produção infográfica e ocorre anualmente em Pamplona, na Espanha. Para Cairo (2014c), trata-se da Meca para pesquisadores e profissionais da infografia, "[...] o lugar para encontrar as referências profissionais [da infografia] e aprender com elas" (CAIRO, 2014c).
} 
Infolide, além de realizar conferências, organiza a Mostra Nacional de Infografia, ${ }^{13}$ que reúne notáveis exemplos da produção infográfica brasileira.

\subsubsection{Divergências de terminologia, conceito e extensão de uso}

Uma vez explicitado que, para efeitos de nossa pesquisa, infográfico é um produto midiático do Jornalismo e que sua existência na imprensa é recente, sobretudo na plataforma on-line, podemos nos concentrar nas apropriações dos termos infografia e infográfico a fim de esclarecer de que forma os abordamos.

Buscando compreender a inexistência de definição precisa em torno da infografia, destacamos o principal fator que, a nosso ver, é a raiz inicial dessa problemática: a tradução do termo inglês infographics para português, que suscita, por sua vez, divergências quanto à extensão de uso da infografia.

Por razão morfológica, ocorre, tendencialmente, a tentativa de decompor infografia e infográfico nos vocábulos 'info' e 'grafia', que resulta na fórmula estendida 'informação + gráfico’. No entanto, como assinala Cairo (2008, p. 31), o perigo dessa fórmula é associar informação aos elementos verbais e gráfico aos elementos visuais, provocando, assim, uma compressão dissociável e subordinada entre texto e imagem, em que só o primeiro teria valor informativo.

Tendo em vista a estrutura das palavras, autores como Ribas (2005b), Sancho (2001), Sojo (2002) e Teixeira (2010) assinalam que os termos infografia e infográfico são frutos de má tradução para português. Assim como no espanhol, os termos foram traduzidos para português a partir da palavra inglesa infographics, uma abreviação de informational graphics:

No inglês, graphics é diagram, mas diagram, não é o mesmo que chart ou graph, as traduções corretas para 'gráfico', em português. Por outro lado, chart e graph podem ser diagrams, porém, o contrário não ocorre, ou seja, diagram não é o mesmo que chart ou graph. Se fizermos, portanto, a tradução correta do inglês para o português identificaremos que 'diagrama' não é sinônimo de 'gráfico', embora em nossa língua o seja. Isto nos permite sugerir que a tradução mais correta para a origem do conceito de 'infográfico' ou

\footnotetext{
13 As galerias da Mostra Nacional de Infografia podem ser acessadas digitalmente em: $<$ http://www.infolide.com/p/mostra-de-infografia.html>. Acesso em: set. 2012.
} 
'infografia', infographics, seja 'diagrama informativo' (RIBAS, 2005b, p. 4, grifos originais).

A tradução mais correta, segundo Ribas (2005b), de informational graphics para o português, 'diagrama informativo', abrange as diversas estruturas semânticosintáticas que o infográfico pode assumir:

Infografias podem conter gráficos, mas não são gráficos, são diagramas. Gráfico é necessariamente construído sobre o eixo cartesiano, enquanto infografia é uma combinação de formas gráficas que mostra partes de coisas, funcionamento, operação de processos (RIBAS, 2005b, p. 10).

Concordamos com a autora quanto ao fato de os infográficos possuírem possibilidades semânticas, sintáticas e pragmáticas mais amplas do que gráficos e mapas. Não consentimos, entretanto, com o desdobramento inverso desse pressuposto, que embasa o argumento de certos autores, como Ribas (2005b), Sojo (2002) e Teixeira (2010), de que mapas e gráficos não podem compor, isoladamente, infográficos. A defesa de que mapas e gráficos são manifestações gráficas, mas não constituem infográficos, fundamenta-se sobretudo na premissa de que essas formas não apresentam narrativa. ${ }^{14}$ No entanto, além de nos parecer inconsistente, tal premissa distancia-se do atual cenário produtivo, no qual infográficos que cruzam dados quantitativos e geográficos se tornam cada vez mais evidentes na prática jornalística contemporânea, ${ }^{15}$ sobretudo após o infográfico baseado em dados Sector Snapshot: retailing, ${ }^{16}$ do The New York Times, ganhar medalha de ouro no Malofiej Awards, em 2007. Outro exemplo, mais atual, é o infográfico State Gun Laws Enacted in Year Since Newton (Figura 10), também do The New York Times, vencedor do Malofiej Awards, em 2014, em duas das principais categorias do concurso: medalha de ouro em reportagem impressa e prêmio Peter Sullivan /Best of Show.

\footnotetext{
${ }^{14}$ Narrativa ou narração são termos que designam discursos (relato escrito, oral ou visual) "[...] de acontecimentos ou circunstâncias que envolvem a ação, o movimento, e o transcorrer do tempo..." (RABAÇA, BARBOSA, 1987). Embora certos autores, como Lage (1985, p. 16), defendam a ideia de que a estrutura da notícia jornalística se baseia mais na exposição de fatos e eventos por ordem de importância do que, propriamente, na narração de fatos e eventos organizados sequencialmente no tempo, reconhecemos a existência de elementos narrativos como ação, tempo, personagens e objetos nos produtos jornalísticos.

${ }^{15}$ Em suas últimas edições, o Malofiej Awards vem premiando, nas categorias impresso e on-line, infográficos com base em dados que revelam evidências quantitativas, entre outras, sobre o conteúdo. Sobre polêmicas geradas em torno desse assunto, ver Teixeira (2010, p. 38) e Alvim (2012, p. 9-14).

16 Disponível em: <http://www.nytimes.com/packages/html/business/20060402_SECTOR_GRAPHIC/index. html>. Acesso em mar. 2014.
} 


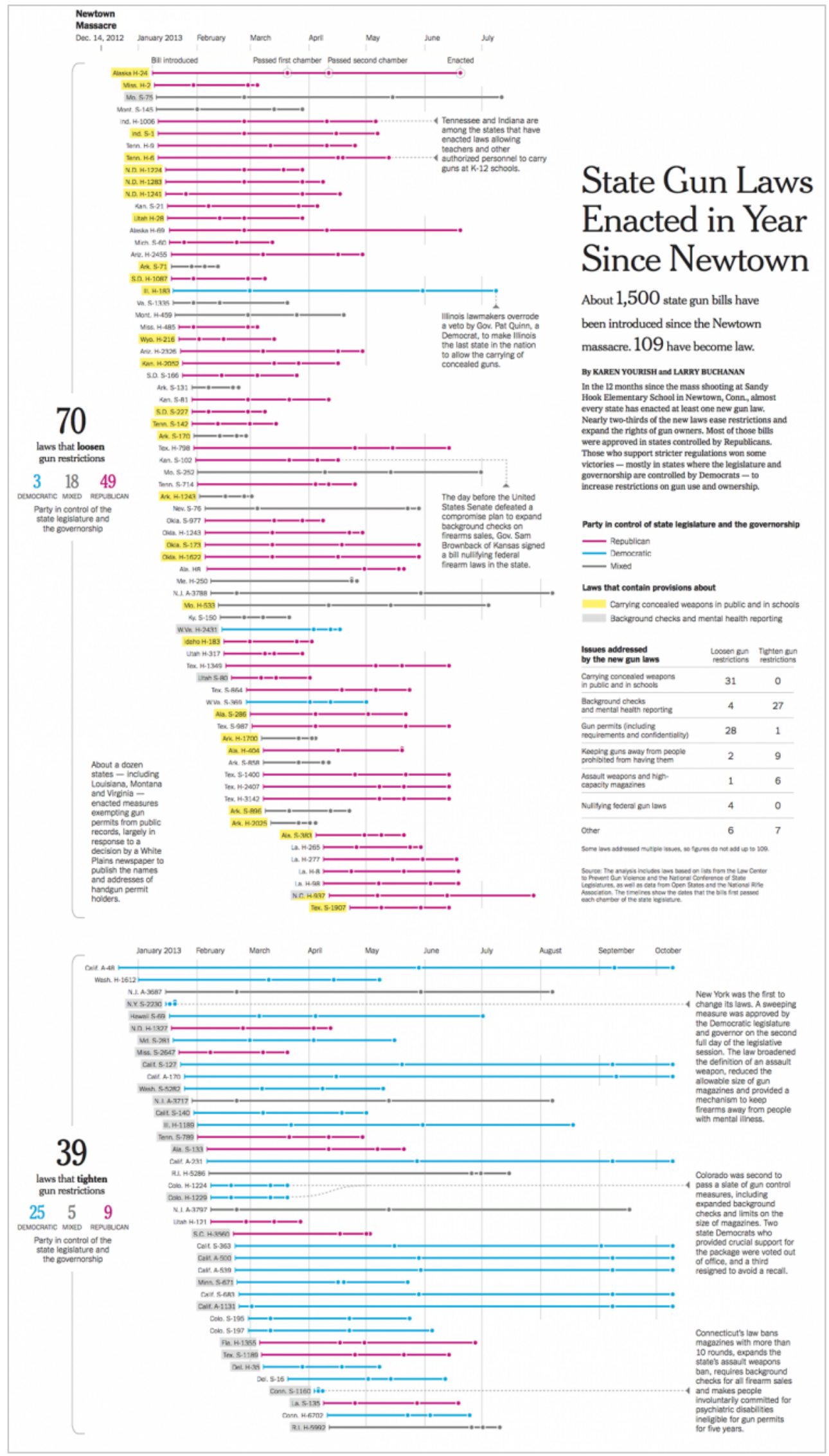

Figura 10 - Infográfico vencedor do Malofiej Awards em 2014 Fonte: Malofiej, $2014 .{ }^{17}$

${ }^{17}$ Disponível em: <http://www.malofiejgraphics.com/m22-awards-final-list/>. Acesso em abr. 2014. 
Para Lucas (2010), a necessidade de certo autores, sobretudo de língua espanhola e portuguesa, de restringir a amplitude de manifestações esquemáticovisuais pertencentes ao campo da infografia, reflete-se na preocupação com a tradução do termo infographics do inglês para línguas latinas e também parece ser em “[...] decorrência do fato de que a discussão sobre gêneros jornalísticos é historicamente sólida em língua espanhola [...]” (idem, p. 9). Segundo o autor, na literatura brasileira e espanhola sobre o tema, abordagens da infografia como gênero ou subgênero jornalístico predominam sobre abordagens da infografia como linguagem, na qual a ênfase está sobre os elementos do design. Dessa forma, “[...] a infografia já não é mais um elemento uno, caracterizável apenas semioticamente por seus elementos gráficovisuais, mas também pela sua ênfase total ou parcial em relação às clássicas perguntas do jornalismo" (idem, p. 10).

Em tentativa de sistematizar a variedade de definições e extensões de uso da infografia, conjugamos nossos esforços aos de Lucas (2010) e Rodrigues (2009) para reunir autores que abordam, segundo diversas perspectivas, o tema aplicado ao Jornalismo, impresso e/ou on-line (Quadro 8).

Quadro 8 - Definições e extensões de uso da infografia

\begin{tabular}{|c|c|c|}
\hline Autor & Definiçãa & $\begin{array}{l}\text { Extensão } \\
\text { conceitual }\end{array}$ \\
\hline $\begin{array}{l}\text { Peltzer } \\
\text { (1992, p. 134) }\end{array}$ & $\begin{array}{l}\text { "Expressões gráficas, mais ou menos complexas } \\
\text { de informações, cujo conteúdo são } \\
\text { fatos/acontecimentos, a explicação de como algo } \\
\text { funciona" }\end{array}$ & $\begin{array}{l}\text { Gráficos e mapas } \\
\text { não equivalem a } \\
\text { infográficos }\end{array}$ \\
\hline $\begin{array}{l}\text { De Pablos } \\
(1999, \text { p. 19) }\end{array}$ & $\begin{array}{l}\text { "A infografia é a apresentação impressa de } \\
\text { um binômio imagem + texto (bI +T), qualquer } \\
\text { que seja o suporte onde se apresenta essa } \\
\text { união informativa: tela, papel, plástico, barro, } \\
\text { pergaminho, papiro, pedra" }\end{array}$ & $\begin{array}{l}\text { Gráficos e mapas } \\
\text { não equivalem a } \\
\text { infográficos }\end{array}$ \\
\hline $\begin{array}{l}\text { Leturia } \\
\text { (1998) }\end{array}$ & $\begin{array}{l}\text { “O infográfico, como uma notícia, deve responder às } \\
\text { perguntas jornalísticas 'O quê?', 'Quem?', 'Quando?', } \\
\text { 'Onde?', ; 'Como?' e 'Por quê?', e, além disso, deve } \\
\text { apresentar as informações visualmente” }\end{array}$ & $\begin{array}{l}\text { Gráficos e mapas } \\
\text { equivalem a } \\
\text { infográficos }\end{array}$ \\
\hline $\begin{array}{l}\text { Sojo } \\
(2002)\end{array}$ & $\begin{array}{l}\text { A infografia é um gênero jornalístico “[...] para } \\
\text { mostrar informações de maneira gráfica, sempre que } \\
\text { a solução escrita resultar em operações complicadas e } \\
\text { tediosas. Por exemplo: uma perseguição policial, um } \\
\text { acidente [...] ou uma sequência de ações" }\end{array}$ & $\begin{array}{l}\text { Gráficos e mapas } \\
\text { não equivalem a } \\
\text { infográficos }\end{array}$ \\
\hline
\end{tabular}




\begin{tabular}{|c|c|c|}
\hline $\begin{array}{l}\text { Sancho } \\
\text { (2001, p. 201). }\end{array}$ & $\begin{array}{l}\text { "Contribuição informativa realizada com elementos } \\
\text { icônicos e tipográficos, que permite ou facilita } \\
\text { a compreensão dos acontecimentos, ações ou fatos } \\
\text { da atualidade [...]" }\end{array}$ & $\begin{array}{l}\text { Gráficos e mapas } \\
\text { equivalem a } \\
\text { infográficos }\end{array}$ \\
\hline $\begin{array}{l}\text { Colle } \\
(1998, \text { apud } \\
\text { SOJO, 2002) }\end{array}$ & $\begin{array}{l}\text { "[...] a infografia é uma disciplina do Design Gráfico } \\
\text { orientada para a produção de unidades informáticas } \\
\text { verbo-icónicas chamadas, preferencialmente, } \\
\text { de infógrafos", embora talvez seja melhor o termo } \\
\text { "infográfico" }\end{array}$ & $\begin{array}{l}\text { Gráficos e mapas } \\
\text { não equivalem a } \\
\text { infográficos }\end{array}$ \\
\hline $\begin{array}{l}\text { Yanes Mesa } \\
(2004, \text { apud } \\
\text { CAIRO, 2008, } \\
\text { p. } 31)\end{array}$ & $\begin{array}{l}\text { "A infografia é um recurso eficaz, especialmente } \\
\text { utilizada em reportagens, ainda que seja comum } \\
\text { encontrá-la em notícias factuais. Costuma-se usar } \\
\text { a infografia como elemento complementar da } \\
\text { informação" }\end{array}$ & $\begin{array}{l}\text { Não menciona } \\
\text { extensão de uso }\end{array}$ \\
\hline $\begin{array}{l}\text { Ribas } \\
\text { (2005b, p. 15) }\end{array}$ & $\begin{array}{l}\text { "A infografia tem a função de facilitar a comunicação, } \\
\text { ampliar o potencial de compreensão pelos leitores, } \\
\text { permitir uma visão geral dos acontecimentos [...], } \\
\text { tendo como conteúdo explicações em diversos } \\
\text { níveis de complexidade, apresentações de fatos ou } \\
\text { acontecimentos, informações de funcionamento, } \\
\text { descrições de processos" }\end{array}$ & $\begin{array}{l}\text { Gráficos e mapas } \\
\text { não equivalem a } \\
\text { infográficos }\end{array}$ \\
\hline $\begin{array}{l}\text { Cairo } \\
(2008, \text { p. } 36)\end{array}$ & $\begin{array}{l}\text { "A infografia, ou visualização da informação, } \\
\text { não é um objeto decorativo cujo principal escopo } \\
\text { é fazer páginas do jornal mais 'leves', e 'dinâmicas', } \\
\text { 'coloridas', mas sim uma ferramenta analítica da } \\
\text { realidade a serviço dos leitores e em prol da } \\
\text { compreensão" }\end{array}$ & $\begin{array}{l}\text { Gráficos e mapas } \\
\text { equivalem a } \\
\text { infográficos }\end{array}$ \\
\hline $\begin{array}{l}\text { Teixeira (2010, } \\
\text { p.18, grifos } \\
\text { originais) }\end{array}$ & $\begin{array}{l}\text { A infografia é um subgênero da modalidade } \\
\text { informativa, e “[...] um bom infográfico costuma } \\
\text { contar com recursos visuais diversos como } \\
\text { fotografias, mapas, tabelas [...]. Mas um mapa é, } \\
\text { por princípio, um infográfico jornalístico? O limite, } \\
\text { acreditamos, dar-se-ia a partir de uma equação } \\
\text { bastante simples: um infográfico jornalístico [...] } \\
\text { pressupõe uma narrativa [...]” }\end{array}$ & $\begin{array}{l}\text { Gráficos e mapas } \\
\text { não equivalem a } \\
\text { infográficos }\end{array}$ \\
\hline
\end{tabular}

Fonte: elaboração própria adaptada de Rodrigues, 2009 e Lucas, 2010.

Por meio do Quadro 8, percebe-se que os autores citados tendem a distinguir a produção de representações esquemática como mapas e gráficos ${ }^{18}$ de infográficos jornalísticos. Paralelamente, autores que deixam essa oposição de lado - Cairo (2008), Leturia (1998) e Sancho (2001) - percebem a infografia de forma mais ampla e não

\footnotetext{
${ }^{18}$ Em seu artigo, Lucas (2010), inclui a produção de tabelas numéricas na discussão acerca da extensão conceitual de infografia. Para efeitos de nossa pesquisa, não consideraremos tabelas infográficos, embora, reconheçamos a existência de tabelas hibridizadas e sofisticadas.
} 
estabelecem fronteiras distintivas entre o que pode e o que não pode ser um infográfico: “[...] fica claro que o interesse maior é nas possibilidades visuais de representação dos fatos e dados, e no domínio dessas linguagens por parte do profissional [...]" (LUCAS, 2010, p. 7).

Por um lado, abordagens sobre infografia, do ponto de vista do gênero jornalístico informativo, sobretudo em Teixeira (2010), são relevantes para reiterar que ela não pode ser desvinculada dos princípios do campo de aplicação em que está inserida. Dessa forma, infográficos submetem-se à lógica jornalística e incorporam características narrativas e funções informativas predominantes. Leturia (1998) e Sojo (2002) estabelecem que o infográfico é composto de elementos estruturais básicos, a saber: 1) título: texto direto, preferencialmente sintético, que exprime o conteúdo do infográfico; 2) texto explicativo: texto sucinto que oferece ao leitor todas as explicações necessárias para compreender o infográfico; 3) corpo da informação: a essência do infográfico, a representação gráfica com elementos visuais e textuais; 4) fonte: indicação da origem dos dados e 5) crédito: indicação do autor ou autores do infográfico, assim como o nome da publicação. Concordamos com a ideia de que todos os infográficos possuem, ou ao menos deveriam possuir, esses elementos para cumprir suas funções primordiais na explanação do conteúdo ao leitor de modo efetivo e referencial.

Por outro lado, extensões conceituais amplas, sobretudo em Cairo (2008; 2013), são importantes para que infográficos sejam compreendidos como produtos midiáticos versáteis e dinâmicos, antenados com práticas jornalísticas contemporâneas, sem delimitar, de antemão, estruturas sintáticas que esses devem assumir. Para o autor, a discussão conceitual entre infográficos, gráficos e mapas, entre outras possíveis representações esquemáticas, é substituída por proposta tipológica em duas categorias que caracterizam tendências atuais na produção infográfica (CAIRO, 2008, p. 28-35): corrente estetizante, na qual são enfatizados aspectos como poder e impacto visual do infográfico para proporcionar páginas jornalísticas mais atrativas, leves e dinâmicas; e corrente analítica, na qual se altera a função primordial do infográfico tendo-se em vista o crescente uso de bases de dados no Jornalismo e as técnicas da visualização da informação. Aprofundando-se nessa segunda corrente, a analítica, o autor sugere que o “[...] infográfico é uma 
representação diagramática de dados"19 (idem, p. 21) e quaisquer que sejam a forma ou formas gráficas representadas em um infográfico, esse se constitui como “[...] uma ferramenta de amplificação da cognição e da memória" (idem, p. 34). Essa acepção aproxima-se da conjuntura em que buscamos compreender a infografia atual, inserida em um contexto jornalístico que busca significar dados brutos por meio de cruzamentos e visualizações que evidenciam relações de natureza quantitativa, grupal, conectiva, temporal e geográfica. Finalmente, Cairo promove o encontro entre infografia e visualização da informação, que são tratados pelo autor, na corrente analítica, como termos sinônimos:

[...] a visualização da informação na imprensa é um suporte para a compreensão: ela incrementa a capacidade cognitiva dos leitores por meio da revelação de evidências [...] seja de um conjunto de dados complexos, de uma lista numérica ou de um objeto cuja estrutura interna seja excessivamente complexa (CAIRO, 2008, p. 29).

É durante a produção infográfica de corrente analítica, contextualizada na maioria das vezes pelo jornalismo de $\operatorname{dados},{ }^{20}$ que organizações informativas e configurações visuais oriundas da visualização da informação sãos incorporadas à infografia, resultando em representações gráficas diferenciadas. O produto que emerge desse encontro não possui denominação precisa. Encontramos, durante a revisão bibliográfica, diferentes denominações, nem todas atribuídas ao contexto jornalística, a saber: 1) visualização de dados, dataviz e datavis; 2) visualização da informação, infoviz e infovis; 3) visualização analítica e infografia analítica (CAIRO, 2008; 2013) e 4) infografia em base de dados ou infobases (RODRIGUES, 2009). Assumimos o termo infovis para designar nosso objeto de pesquisa, um dispositivo midiático em projeção que se situa nas interfaces de três principais referências teóricas: visualização da informação, infografia jornalística e interatividade, esta última abordada no final do presente capítulo. Como assinalado em nota no

\footnotetext{
${ }^{19} \mathrm{Na}$ definição de Cairo, o termo diagramático é utilizado no sentido de esquemático, ou seja, uma "[...] representação abstrata de uma realidade" (CAIRO, 2008, p. 22).

${ }^{20} \mathrm{O}$ jornalismo de dados é uma especialidade jornalística que busca extrair sentido de dados brutos e produzir notícias por meio deles. Para o especialista em jornalismo de dados Simon Rogers (ex-editor da seção Datablog, do The Guardian) a emergência dessa prática em redações pode ser atribuída a dois principais fatores: 1) avanços das tecnologias informáticas, principalmente a proliferação de aplicativos de software acessíveis e gratuitos como Google Fusion Tables e Tableau Public e 2) aumento da prática do open data (dados abertos), isto é, crescimento de dados governamentais disponibilizados publicamente para livre acesso aos cidadãos e jornalistas (ROGERS, 2011).
} 
Capítulo 1 (p. 39), reiteramos que infovis, quando escrito da forma explicitada na presente dissertação, constitui neologismo adotado por nós para qualificar, especificamente, nosso objeto de pesquisa e caracterizar as peças constituintes de nosso corpus. Encontramos referências ao termo infovis, que, embora expressem conceitos similares, apresentam as seguintes variâncias em nomenclatura e aplicação de uso: 1) infovis e infoviz: formas abreviadas de Information Visualisation (do inglês britânico) e Information Visualization (do inglês americano); 2) InfoVis: conferência anual dedicada à pesquisa da visualização da informação que integra submissão de trabalhos, palestras e workshops e 3) InfoVis.net: “[...] sítio web que coloquei em prática em julho de 2000 com o suporte do material do Departament de Tecnologia de la Universitat Pompeu Fabra com objetivo de documentar e compreender essa jovem disciplina [visualização da informação]" (DÜRSTELER, 2003, p. 15).

Voltando ao infográfico vencedor da principal categoria do Malofiej Awards ${ }^{21}$ em 2014 (Figura 10, p. 68) e o analisando mais atentamente, percebemos que ele apresenta propriedades da infografia jornalística e da visualização da informação, mas não é interativo. Embora não nos interesse rotular representações gráficas em categorias tipológicas, esse infográfico pode ser considerado a hibridização de uma linha do tempo (ENGELHARDT, 2002, p. 140) e apresenta todos os elementos estruturais básicos que um infográfico, segundo Leturia (1998), deve possuir: título, texto explicativo, corpo da informação, fonte e crédito. O corpo da informação, que é representação gráfica em si, inclui elementos visuais esquemáticos e textos comentados. Não existem elementos figurativos, como fotografias e ilustrações, porém linha, cor, ponto, posição no plano, etc. configuram referências que operam segundo princípios da Comunicação Visual e, portanto, constituem imagens. Conjugação entre elementos estruturais do infográfico, variáveis visuais (tamanho, valor, cor, forma, orientação e textura) implementação no plano (pontos, linhas e áreas) e organização dos componentes (seletivo, ordinal, quantitativo e geográfico) desencadeiam a narrativa de um acontecimento baseado em dados não figurativos e respondem às perguntas jornalísticas. Em outras palavras, com certo esforço cognitivo para decodificar o conteúdo representado esquematicamente, é possível visualizar e

\footnotetext{
${ }^{21}$ Malofiej Awards é apontado como a mais importante premiação mundial para infografia jornalística.
} 
compreender uma história (com cenário, personagens e desencadeamento de ações) contada a partir de dados. Título e texto explicativo do infográfico respondem a pelo menos três perguntas jornalísticas: leis sobre armas ('o quê?') foram propostas e eleitas pela maioria do estados dos Estados Unidos ('onde?') após massacre ocorrido em escola de Newtown ('quando?'). A explicação, que responde ao 'como?' e 'por quê?', fica a cargo do corpo da informação, ou seja, a estrutura gráfico-textual evidencia, por meio da organização, implementação no plano e variável visual dos dados representados, relações de causa e efeito que refletem posturas político-ideológicas de estados e partidos norte-americanos. Por exemplo, é possível visualizar que estados republicanos (em cor-de-rosa) tendem a eleger leis que diminuem a restrição quanto ao porte de arma, enquanto estados democráticos (em azul) tendem a eleger leis que aumentam a restrição quanto ao porte de arma.

$\mathrm{Na}$ presente pesquisa, a despeito das destacadas incongruências entre os termos infografia, infográfico, gráfico e diagrama, utilizaremos:

- infografia e infográfico para designar, respectivamente, a prática profissional e os produtos midiáticos decorrentes dessa prática, em todos os formatos e plataformas em que podem ocorrer, desde que sejam jornalísticos e tenham intencionalidade informativa;

- o termo infovis, nosso objeto de estudo, para designar uma modalidade específica de infográfico, que é resultado do encontro da infografia com a visualização da informação no suporte de circulação on-line e interativo.

Não pretendemos estabelecer o infovis como modelo único de produção infográfica no Jornalismo, nem minimizar outras possibilidades semântico-sintáticas para infográficos, mas estudar um objeto em evidência e projeção. Propriedades e tecnologias da plataforma digital e on-line, principalmente a interatividade, significam, para a infografia, ampliações conceituais e práticas, que acarretam, consequentemente, transformações no que se refere à produção e ao consumo desse produto midiático. 


\subsubsection{Infografia no suporte digital e on-line}

Se, por um lado, a Guerra do Golfo, em 1991, constitui marco histórico para consolidação dos infográficos no jornalismo impresso como “[...] formas diferenciadas de narrar os acontecimentos [...]" (TEIXEIRA, 2010, p. 22) em período em que se buscavam novos mecanismos gráfico-textuais para representação de uma realidade impactante, por outro lado, os atentados de 11 de setembro de 2001, nos Estados Unidos, são destacados por Chimeno $(2003)^{22}$ como divisor de águas na produção de infográficos no suporte on-line (Gráfico 1):

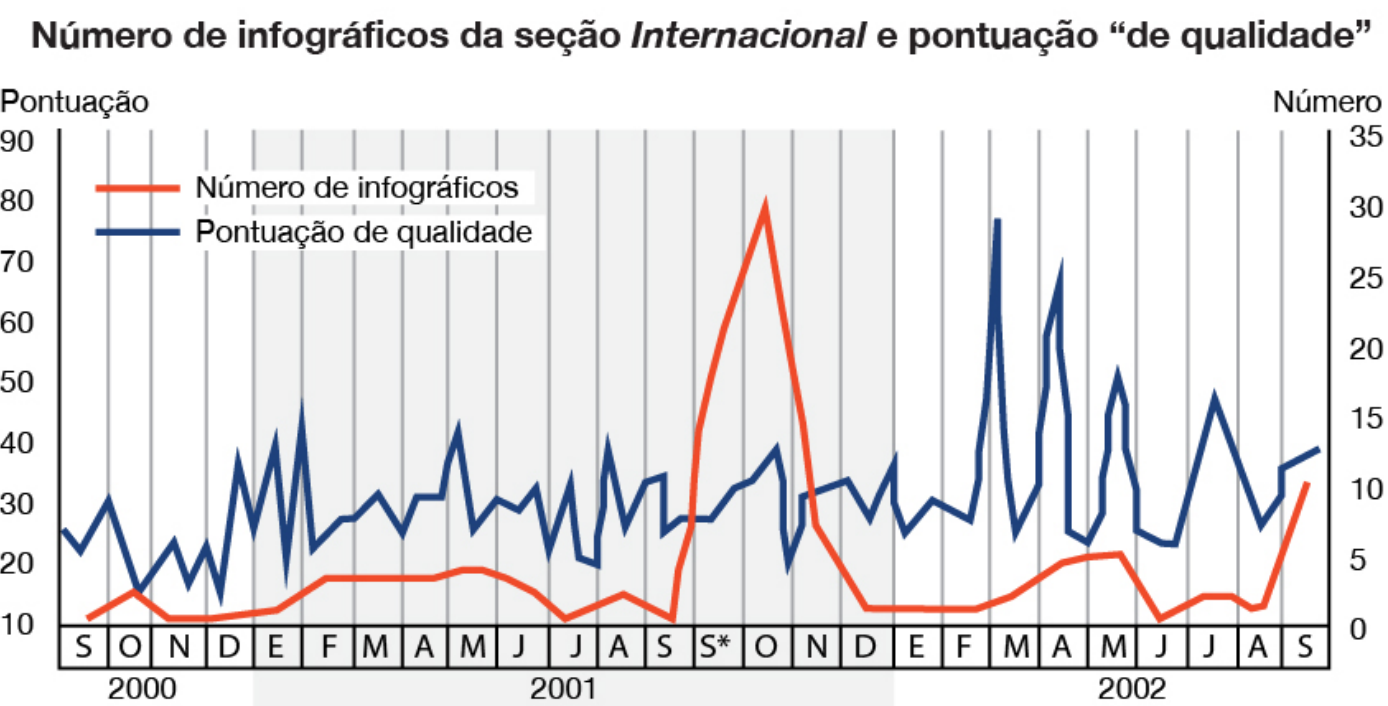

Gráfico 1 - Aumento da produção infográfica no suporte on-line. Fonte: Chimeno, 2003.

A cobertura de guerras e conflitos bélicos, como assinala Cairo (2008, p. 5357), provocou uma verdadeira revolução na produção de infográficos, principalmente nas páginas de jornais de países afetados pelos combates. No entanto, os elementos que permitiram, de fato, melhoria da qualidade infográfica e diversificação de suas representações visuais foram a informatização das redações e a consolidação de uma modalidade comunicacional digital e on-line.

A incorporação de computadores em redações inicia-se na década de 1980, e a introdução dos modelos Macintosh, em 1984, é vista como marco para transformação do exercício do designer profissional em termos de redução de tempo de trabalho e

\footnotetext{
${ }^{22}$ Em sua tese de doutorado, Chimeno (2003) analisa o aumento e qualidade da produção de infográficos da seção Internacional do sítio jornalístico El Mundo, no período entre setembro de 2000 e setembro de 2002.
} 
ampliação de recursos e técnicas disponíveis. Em seguida, surgem avanços na capacidade gráfica dos computadores. Manovich (2011, p. 159) aponta desenvolvimentos tanto no hardware - processadores, velocidade de conexão, memória e display - como no software - melhorias de programas para desktop como Adobe Creative Suit, ${ }^{23}$ novas linguagens de programação, como Flash ${ }^{24} \mathrm{e}$ Processing, ${ }^{25} \mathrm{e}$, finalmente, a disponibilização de APIs ${ }^{26}$ fornecidas por serviços baseados na web. Juntos, desenvolvimentos tecnológicos favorecem novas qualidades para infográficos no suporte digital e on-line, das quais destacamos incorporação de animações, multimidialidade, hipertextualidade, atualização contínua, uso de base de dados e interatividade.

A infografia jornalística desenvolvida no suporte digital e on-line tem recebido denominações e extensões de uso distintas. Alguns autores a chamam de infografia multimídia (RIBAS, 2005a; TEIXEIRA; RINALDI, 2008), infografia interativa (CORDEIRO, 2013;), infografia digital (SANCHO, 2008), infografia 2.0 (CAIRO, 2008), enquanto outros preferem classificar infográficos em fases e estágios de desenvolvimento: lineares, multimídia e em base de dados (RODRIGUES, 2009) ou transposição do impresso, metáfora do impresso, multimídia e em base de dados (AMARAL, 2010). Não obstante as diferentes denominações, todas retratam um mesmo objeto de estudo, destacando determinadas qualidades em detrimento de outras. Assim como expomos produtos midiáticos oriundos do jornalismo on-line pertencentes a distintas etapas evolutivas (p. 58-59), parece-nos oportuno fazer o mesmo com infográficos on-line, a fim de situar em que geração o infovis se encontra. Amaral (2010), em sua dissertação de mestrado, com base em estudos tipológicos anteriores (RIBAS, 2005a; RODRIGUES, 2009; TEIXEIRA; RINALDI, 2008) apresenta proposta tipológica para infográficos produzidos na plataforma on-line em quatro fases, seguindo o desenvolvimento gradativo

\footnotetext{
${ }^{23}$ A Adobe Creative Suite é uma suíte de aplicativos desenvolvidos pela Adobe Systems para projetos de design gráfico, desenvolvimento de páginas web, edição de vídeo, entre outros.

${ }^{24} \mathrm{O}$ software Flash surgiu em 1996 como um programa para criar animações. Os profissionais de infografia logo o incorporaram como uma das principais ferramentas para a produção de infográficos multimídia. Em 2005 o Flash foi comprado pela Adobe Systems e passou a fazer parte do Adobe Creative Suite. Com a ascensão dos dispositivos móveis, no entanto, o Flash vem, paulatinamente, perdendo espaço na produção de produtos multimídia para o HTML5, a quinta versão da linguagem HTML que trouxe novas funcionalidades como web semântica e acessibilidade para os desenvolvedores.

${ }^{25}$ Processing é uma linguagem de programação de código aberto criada em 2001 pelos pesquisadores Casey Reas e Ben Fry, do MIT Media Lab. Um das propostas do Processing é ser uma tecnologia com a qual indivíduos não especializados em programação possam, facilmente, criar produtos visuais e interativos.

${ }^{26}$ Application Programming Interface (API) ou Interface de Programação de Aplicativos.
} 
do Jornalismo praticado na web. O Quadro 9 apresenta as gerações identificadas pelo autor na produção de infográficos, suas caracterizações e exemplos oriundos de sítios jornalísticos. Atribuir gerações não significa, necessariamente, pensar em exclusão e superação. $\mathrm{Na}$ atual produção infográfica, gerações coexistem e continuarão coexistindo, ao menos em um futuro próximo.

Quadro 9 - Gerações da infografia no suporte on-line

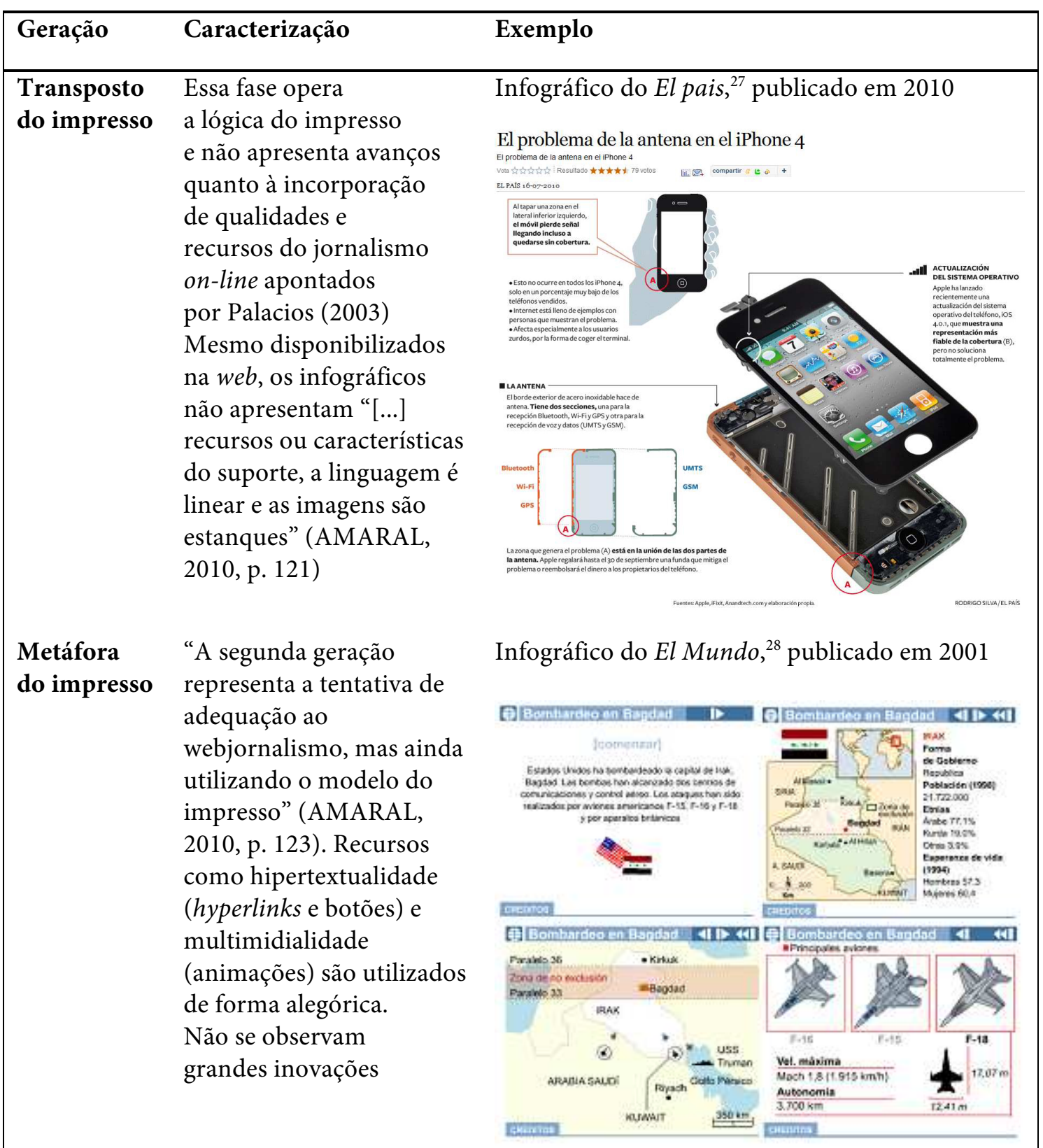

\footnotetext{
${ }^{27}$ Infográfico disponível em: <http://elpais.com/elpais/2010/07/16/media/1279279977_720215.html>. Acesso em mar. 2014.

${ }^{28}$ Infográfico disponível em: <http://www.elmundo.es/elmundo/2001/graficos/febrero/semana3/ataquebagdad .html>. Acesso em mar. 2014.
} 


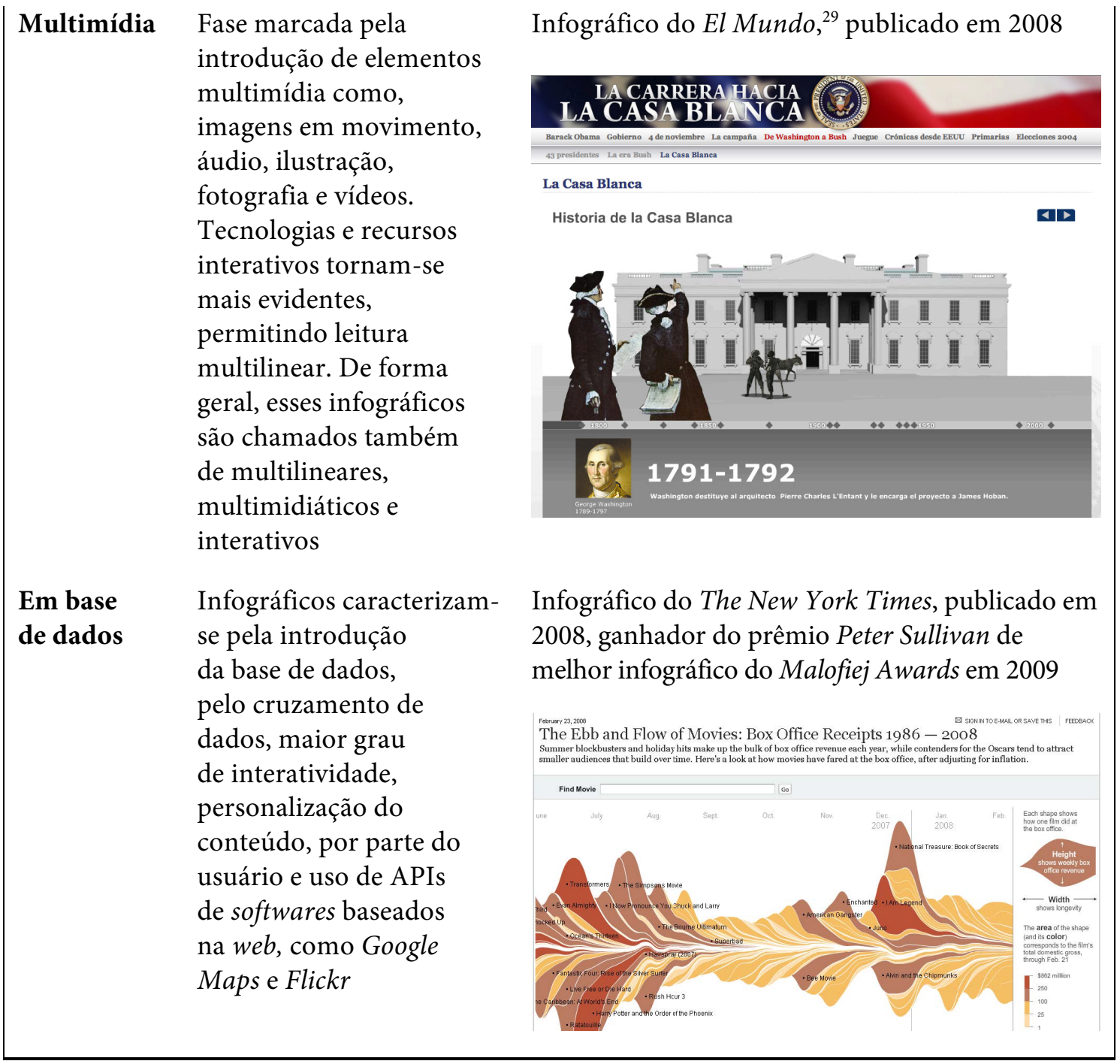

Fonte: Amaral, 2010, p. 119-36.

Como aponta Amaral (2010), infográficos da terceira e quarta geração utilizam, de maneira concreta, características e potencialidades que os suportes digital e on-line oferecem. Enquanto infográficos de terceira geração exploram, principalmente, multimidialidade e hipertextualidade, delineando um movimento de ruptura com a leitura linear, infográficos de quarta geração concentram-se, mais explicitamente, na lógica da base de dados, interatividade e personalização do conteúdo, inaugurando, ainda que em estágio preliminar, novas dinâmicas de produção e consumo do conteúdo.

Discussões no meio acadêmico sobre infográficos de quarta geração, ainda que escassas, assinalam problematização quanto ao fato de tendências - base de dados e

\footnotetext{
29 Infográfico disponível em: <http://www.elmundo.es/especiales/2008/09/internacional/elecciones_eeuu/ presidentes/casa_blanca.html>. Acesso em mar. 2014.
} 
atualização contínua, por exemplo, assim como recursos interativos que permitem ao usuário tornar-se mais ativo no processo jornalístico - convergirem infográficos para modelos comunicacionais mais instrumentais e exploratórios do que propriamente explanatórios e informativos. Seria pretensão cogitar que infográficos de quarta geração, acompanhando discussões recentes acerca de outros produtos midiáticos e práticas do cenário jornalístico contemporâneo, estariam no caminho de expandir e ressignificar o próprio conceito de infografia?

Rodrigues (2009) utiliza o termo infobases para designar infográficos de quarta geração e considera que:

[...] a inserção das bases de dados na infografia modifica sensivelmente os formatos anteriores de visualização multimídia e, pela primeira vez, proporciona a possibilidade do mashup ou a "remixabilidade" (MANOVICH, 2008) de aplicações para o seu funcionamento através da mistura de Google Maps, Flickr, Youtube, etc. e cruzamento dinâmico de dados do ciberespaço ou do arquivo/memória (PALACIOS, 2008) dos próprios sítios jornalísticos (RODRIGUES, 2009, p. 23).

No que concerne a suas características interativas, mais complexas e representativas de dados, as infobases aproximam-se do conceito de infovis que propomos na presente dissertação: um infográfico jornalístico e interativo que se apropria das técnicas da visualização da informação para organizar, cruzar e apresentar relações entre dados, constituindo-se, de tal forma, como um dispositivo midiático de características específicas que tanto demonstra mediação jornalística do conteúdo como permite ao usuário certa autonomia na construção do percurso narrativo por meio de recursos interativos.

Percebemos, no entanto, uma ênfase na conceituação das infobases no que concerne à tecnologia de base de dados, particularmente no uso de aplicativos de softwares baseados na web (APIs), ${ }^{30}$ como o Google Maps, Flickr, ao entrelaçamento de dados por meio de mashups, ${ }^{31}$ Dessa forma, a presença desse tipo de base de dados faz-

\footnotetext{
${ }^{30}$ Application Programming Interface (API) ou Interface de Programação de Aplicativos é um conjunto de instruções e padrões de programação para acesso às funcionalidades e serviços de softwares baseados na web, sem a necessidade de implementação do software em si. Em outras palavras, uma empresa de software - Google - cria seu API para que outros - jornalistas e designers de veículos comunicativos - possam desenvolver produtos infográficos - acionados por aplicativos desse serviço.

31 "Mashup é uma estratégia que se utiliza de diversos aplicativos em fusão para a construção de conteúdo dinâmico que possa misturar Google Maps com Flickr, YouTube, RSS e outros” (RODRIGUES, 2009, p. 37).
} 
se condição para que a infobase seja definida como tal. Uma vez que a base de dados é incorporada no ambiente web, ela pode ser definida como:

[...] um sistema que envolve dados, o hardware, que armazena fisicamente aquele dado, o software, que utiliza o sistema de arquivo para 1) armazenar o dado e 2) prover um método padronizado para recuperar ou mudar um dado e; finalmente, os usuários, que vão transformar o dado em informação (BARBOSA, 2007, p. 46).

Há, portanto, a ideia de que as infobases são construídas por softwares que utilizam dados armazenados em outros diretórios, com base na web ou não, como planilhas do Excel, GoogleDocs, Googlesheets, etc. Em nossa análise, não nos concentramos nesse fator tecnológico como pré-requisito para seleção do corpus, embora o consideremos possível aspecto na produção do que designamos infovis. Para tal, constituímos a subunidade de análise ferramenta de produção por meio da qual observamos se peças do corpus são, ou não, construídas por intermédio de aplicativos de softwares baseados na web (APIs), que constituem, na maioria das vezes, ferramentas on-line e gratuitas. De toda forma, estamos interessados em investigar uma modalidade comunicacional que emerge do infográfico on-line, interativo e com base em dados, que pode ser produzido tanto manualmente, isto é, diretamente construído por meio de software gráfico instalado no computador, como por meio da intermediação de templates gráficos e base de dados armazenados em outros dispositivos.

\subsubsection{Infovis como dispositivo interacional}

Para Foucault (2004, p. 244) um dispositivo é um conjunto de elementos heterogêneos que engloba "[...] discursos, instituições, organizações arquitetônicas, decisões regulamentares, leis, medidas administrativas, enunciados científicos, proposições filosóficas, morais, filantrópicas.”.

Braga (2012a), ao trazer o conceito de dispositivo de Foucault (2004) para o campo da Comunicação, o faz de forma a reforçar o caráter dialógico e tentativo dos processos comunicacionais. Dispositivos não são aparatos tecnológicos, mas espaços nos quais se articulam relações entre interagentes (produtores e consumidores do 
conteúdo), linguagens, lógicas das empresas midiáticas, potencialidades tecnológicas, etc.

Nesse sentido, dentro dos dispositivos interacionais "[...] funcionam as coisas (mensagens e produtos) e suas passagens (circulação) [...]” (BRAGA, 2012a, p. 33), e o processo comunicacional é resultado de ações de participantes e tentativas de interação:

Justamente porque se volta para a apreensão dos sistemas de relações socialmente desenvolvidas entre elementos heterogêneos, o conceito de dispositivos interacionais parece se prestar adequadamente àquela preocupação de enfrentar o desafio da co-presença de aspectos do fenômeno comunicacional ainda vistos como fragmentários, não articulados em formulação teórica. Observar sua articulação prática, na tentativa social de produzir comunicação, promete abrir espaço para proposições e indagações ainda não estabilizadas no conhecimento - ou seja, espaços de descoberta (BRAGA, 2011, p. 14).

Apropriando o conceito de dispositivos interacionais de Braga (2011, 2012a) para nosso objeto, consideramos infovis um dispositivo permeado, por um lado, por relações de mediação do tratamento jornalístico e do design que projetam uma interface gráfico-comunicativa e, por outro lado, por relações interativas que permitem ao usuário explorar o conteúdo e participar mais ativamente da produção de significados.

Em nosso trabalho adotaremos o conceito de dispositivo infovis para descrever um produto midiático do jornalismo on-line que se caracteriza por ser, simultaneamente:

- um infográfico, pois, como produto do jornalismo visual, possui características narrativas, funções informativas e elementos estruturais típicos do gênero jornalístico;

- uma visualização da informação, pois apresenta, mesmo que parcialmente, ${ }^{32}$ organização e apresentação visual baseada em dados e representa as relações estabelecidas entre eles;

- interativo, pois oferece ao usuário mecanismos de interação com o conteúdo.

\footnotetext{
${ }^{32}$ Destacamos o fato de que infovis para ser considerado como tal deve evidenciar a incorporação de elementos de organização e apresentação visual oriundos das técnicas da visualização da informação no infográfico. No entanto, o infovis pode apresentar, simultaneamente, outras modalidades de organização visual e elementos figurativos como fotos, vídeos e animações.
} 
Já apresentamos e discutimos as duas primeiras referências teóricas. Introduzimos agora a propriedade interatividade e suas contribuições para o processo comunicativo no dispositivo infovis.

No contexto do suporte digital, a interatividade torna-se uma característica de reconfiguração dos produtos mediáticos responsáveis “[...] pela integração do usuário no processo de produção jornalístico" (SCHWINGEL, 2012, p. 54). Distintos autores desenvolvem o conceito da interatividade na Comunicação sob diversas perspectivas e apontam seus desdobramentos no processo comunicativo. De modo geral, ainda que algumas formas de interatividade possam ser compreendidas amplamente e fora do ambiente virtual, nossa abordagem acompanha a visão segundo a qual a interatividade está intimamente ligada aos meios digitais e à evolução da informática.

Para Lemos (2010) há três noções de interatividade no ciberespaço A primeira, mais básica, é analógico-mecânica e diz respeito à interação homem/máquina (interações mecânicas como ligar e desligar a televisão ou o computador, etc.). Por meio da interface digital, ultrapassa-se a barreira analógicamecânica alcançando-se interações entre homem/conteúdo informativo, processo que o autor denomina interatividade eletrônico-digital. Finalmente, a interatividade social, ou homem/homem, é aquela que é experimentada como técnica e como prática social. Mielniczuk (1998), no contexto do jornalismo on-line, desdobra a classificação de interatividade de Lemos (2010) em: 1) usuário/máquina; 2) usuário/conteúdo; 3) usuário/usuário e 4) usuário/jornalista. Já na visão de Palacios (2003, p. 3), a interatividade consiste, principalmente, na capacidade que uma notícia on-line tem de aproximar o leitor do processo jornalístico, como, por exemplo, “[...] pela troca de e-mails entre leitores e jornalistas, através da disponibilização da opinião dos leitores, como é feito em sites que abrigam fóruns de discussões, através de chats com jornalistas, etc.”. A ênfase de Palacios está nas relações interativas do tipo homem/homem.

Percebemos então que a interatividade com produtos midiáticos do jornalismo on-line, entre eles o infovis, pode ocorrer por meio de duas principais vias: 1) interação entre usuário e conteúdo informativo, que será manifestada na escolha dos percursos e ordem de navegação realizada por meio de recursos de interatividade; 2) interação do usuário com outros usuários ou com equipe de produção e ainda 3) 
interação de nível de registro, que explicaremos a seguir. Para certos autores (MURRAY, 2003; PLAZA, 2003, PRIMO; TRÄSEL, 2006) a interatividade, compreendida como ação autônoma e criativa, só é de fato manifestada por meio do segundo caminho, com base no agenciamento individual, que segundo Murray (2003 p. 127) é a “[...] capacidade gratificante de realizações significativas e ver os resultados de nossas decisões e escolhas".

Para efeitos de pesquisa, consideramos que a interatividade praticada em infovis é manifestada em ambos os direcionamentos e reflete diferentes usos do output do dispositivo. Com intuito de reforçar diferentes tipos e gradientes de interatividade, a observaremos, em nosso corpus, sobre unidades de análise distintas: interatividade e participação.

Independentemente do direcionamento em que se enquadra determinado tipo de interatividade, nossa postura é de que essa não deve ser, ao menos em teoria, extravagância técnica e experimental, mas sim qualidade que permita aos usuários construir percursos mais autônomos de leitura, traçando estratégias de busca, seleção, comparação do conteúdo e, até mesmo, contribuindo por meio de ações participativas para o processo comunicativo dialógico e multidirecional.

Salaverría (2005, p. 34), estabelece que a interatividade com produtos jornalísticos é gradativa e pode ser mensurada a partir do volume de mudanças que usuários realizam nas trajetórias de suas leituras. Dessa forma o autor estabelece quatro níveis de interatividade:

1. transmissão: trata-se do nível mais básico e permite apenas duas possibilidades de interatividade: ativar e cancelar uma emissão;

2. consulta: produz-se em canais bidirecionais nos quais usuários, além de aceitar ou cancelar emissões, selecionam opções em um menu de possibilidades. Usuários controlam quando e que tipo de informação desejam receber. Essa qualidade interativa implica participação mais ativa do usuário;

3. conversacional: permite que o leitor supere o papel de receptor convertendo-se também em emissor de mensagens para outros destinatários. Exemplos: correio eletrônico e chats. 
4. registro: último nível de interatividade alcançado quando o meio é capaz de registrar dados e preferências gerados por usuários, adaptando seu formato e conteúdo. A interatividade de registro possibilita a personalização do conteúdo, mas, normalmente, há maneiras de os jornalistas (produtores da informação) selecionarem ou filtrarem informações registradas (gatekeeping ${ }^{33}$ ).

Podemos associar os dois primeiros níveis, transmissão e consulta, à interatividade de tipo usuário/conteúdo, que será avaliada nas peças do nosso corpus por meio da unidade de análise interatividade. Já os níveis conversacional e de registro serão avaliados pela segunda unidade de análise, participação. Enquanto o nível conversacional representa uma interação de tipo usuário/usuário ou usuário/jornalista, o nível de registro corresponde à ação interativa na qual conteúdos e suas representações gráficas são adaptados por meio de preferências e dados dos usuários inseridos na interface do dispositivo. Schwingel (2012, p. 56) sugere que este último nível de interatividade seja de tipo conteúdo/conteúdo.

A interatividade com o dispositivo infovis, na plataforma digital, é, sobretudo, do tipo usuário/conteúdo. A partir de algumas contribuições -1) técnicas usadas na navegação de visualizações, apontadas por Tidwell (2006 apud CAIRO 2008, p. 7894); 2) aspectos de interatividade, observados por Segel e Heer (2010); 3) taxonomia de tipos de tarefas interativas, sugerida por Shneiderman (1996) e 4) características do jornalismo on-line, estabelecidas por Palacios (2003) - compomos a subunidade de análise gradiente de interatividade que reconhece, em cada infovis, presença ou ausência de dez recursos interativos de exploração do conteúdo: avançar/retroceder ou iniciar, roll over, zoom, filtragem, relação, busca, extração, customização, outro painel de controle, e hipertextualidade. Em nossa análise, para uma peça ser considerada infovis, ela precisa apresentar ao menos um desses dez recursos interativos. Definições operacionais, para cada recurso interativo, que consideramos parâmetros para análise da unidade interatividade são apresentadas no próximo capítulo (ver Quadro 17, p. 114-116).

\footnotetext{
${ }^{33}$ Gatekeeping é conceito utilizado no Jornalismo para explicar "[...] o desenvolvimento do fluxo de notícias dentro dos canais organizacionais dos aparatos de informação e, sobretudo, para definir os pontos que funcionam, como "cancelas", que determinam se a informação passa ou é rejeitada" (WOLF, 2010, p. 184).
} 
Paralelamente, a unidade participação observa interações de nível conversacional e registro. Identificamos três ações participativas que podem ser realizadas (Quadro 10), mas não constituem manifestações obrigatórias em infovis. Essas ações correspondem à três subunidades de análise em nossa pesquisa: comentário e compartilhamento - ações participativas que caracterizam o nível conversacional - e conteúdo gerado pelo usuário - ação participativa que caracteriza o nível de registro. Um infovis não precisa apresentar tais propriedades para ser caracterizado interativo; no entanto, o nível de registro pode apontar um cenário promissor e pioneiro para a produção de infovis sintonizada com práticas do jornalismo contemporâneo.

Quadro 10 - Ações participativas

\begin{tabular}{|lll|}
\hline $\begin{array}{l}\text { Nível de } \\
\text { interatividade }\end{array}$ & $\begin{array}{l}\text { Ações } \\
\text { participativas }\end{array}$ & $\begin{array}{l}\text { Qualidade } \\
\text { da interação }\end{array}$ \\
\hline Conversacional & $\begin{array}{l}\text { Comentário } \\
\text { Compartilhamento }\end{array}$ & $\begin{array}{l}\text { Usuário/jornalista ou usuário/usuário } \\
\text { Registro }\end{array}$ \\
$\begin{array}{l}\text { Conteúdo gerado pelo } \\
\text { usuário }\end{array}$ & Conteúdo/conteúdo \\
\hline
\end{tabular}

Fonte: elaboração própria. 


\section{Proposta de \\ análise de infovis}

A análise de conteúdo configura-se como importante ferramenta de investigação que permite aos pesquisadores analisar unidades informativas de textos em termos de suas qualidades simbólicas e papéis comunicativos, mostrando-se apropriada para estudo da linguagem jornalística. A análise de conteúdo pode ser definida como “[...] técnica de pesquisa utilizada para tornar inferências ${ }^{1}$ sobre textos (e outros materiais significantes como imagens, sons, símbolos, etc.) replicáveis e validáveis em seus contextos de uso (KRIPPENDORFF, 2004, p. 18). Nesse sentido, entendemos que: 1) como técnica, a análise de conteúdo envolve procedimentos especializados; 2) para resultados serem replicáveis, procedimentos técnicos devem ser sistemáticos, de forma que qualquer pesquisador, em qualquer circunstância, chegue ao mesmo resultado para um mesmo conjunto de dados e 3) para resultados serem válidos, critérios que compõem a análise de conteúdo devem ser desenvolvidos e descritos minuciosamente para que processos de amostragem, leitura e análise satisfaçam esses critérios.

O conteúdo “[...] emerge no processo de análise do texto em contexto particular" (KRIPPENDORFF, 2004, p. 19), o que nos orienta para um modo específico de compreender conteúdo e, consequentemente, proceder sua análise. Nessa perspectiva reside a principal crítica de Krippendorff sobre a definição original de Berelson, segundo o qual a análise de conteúdo corresponde à “[...] técnica de pesquisa para descrição objetiva, sistemática e quantitativa do conteúdo manifesto da comunicação (BERELSON, 1952, p. 18). Para Krippendorff, a expressão conteúdo manifesto da comunicação implica visão reducionista na qual o conteúdo está contido nas mensagens e pode ser separado seus usos, contexto e forma para, então, ser descrito.

Krippendorff (2004, p. 29-30) destaca quatro componentes conceituais na prática da análise de conteúdo:

\footnotetext{
${ }^{1}$ Para o dicionário Aurélio (1999), inferir é “Tirar por conclusão; deduzir pelo raciocínio [...]”.
} 
- uma ou mais questões de pesquisa a que analistas buscam responder examinando determinado corpus;

- corpus de textos (ou outros materiais significantes, como imagens, sons, símbolos, etc.);

- modelo de análise em função dos objetivos e delimitações do estudo;

- inferências que pretendam responder à(s) questão(ões) da pesquisa.

Esses componentes, por sua vez, estão organizados em processo composto por etapas interligadas (Figura 11) que devem ser percorridas em determinada ordem, sendo sempre possível retornar às etapas anteriores para revisão e aprofundamento:

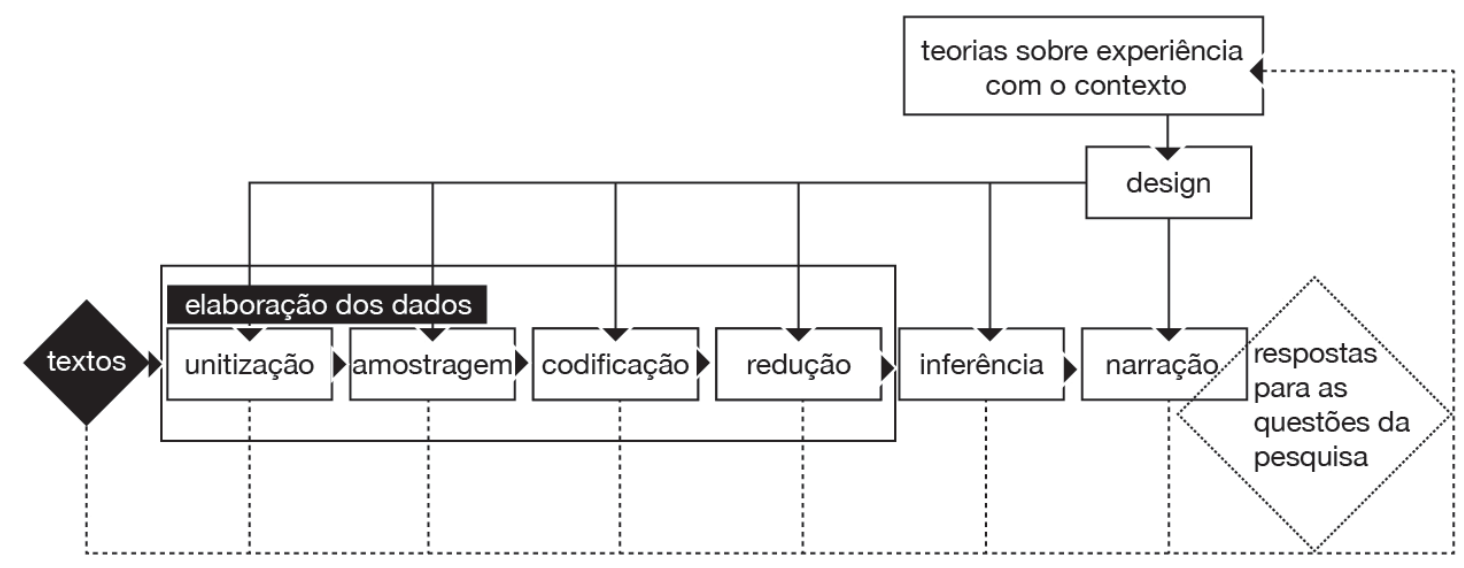

Figura 11 - Etapas da análise de conteúdo. Fonte: Krippendorff, 2004, p. 86.

Aplicamos as etapas da análise de conteúdo (Figura 11) aos objeto e objetivos da presente pesquisa, de forma que teorias sobre experiência com o contexto constituem revisão teórica e elaboração das questões centrais da presente pesquisa abordadas no primeiro e segundo capítulos desta dissertação. A etapa de design da análise de conteúdo compreende outras três principais etapas: elaboração do dados, inferência e narração. A primeira, elaboração do dados, é abordada neste capítulo, enquanto inferência e narração são desenvolvidas no próximo capítulo, intitulado Interpretação dos dados.

Elaboração dos dados compreende quatro subetapas: unitização, que consiste em decisões conceituais e definições de unidades de análise, ou seja, elaboração dos aspectos analíticos e seus respectivos atributos (respostas codificadas); amostragem, que representa conjunto de peças a analisar a partir de especificações definidas; 
codificação, que consiste no preenchimento do formulário de análise segundo medidas de unitização e amostragem; e redução, que compreende depuração da análise a partir de pré-testes que podem representar modificações nas três últimas subetapas. A redução melhora a qualidade do método e a confiabilidade dos resultados. Uma vez concluída a etapa elaboração dos dados, passa-se às inferências, que consistem em conclusões induzidas pela leitura dos dados codificados no formulário, e, finalmente, à narração, que consolida reflexões sobre resultados observados, oferecendo dimensão compreensível e prática para contextos de uso observados na pesquisa. Nessa dissertação, percebemos que a leitura dos dados da análise suscitaram, em alguns momentos, conclusões específicas para o corpus, e, em outras situações, inferências que podem ser expandidas para além da amostra.

Sobre a análise de conteúdo em Jornalismo, Herscovitz (2010, p. 129) aponta ser necessário “[...] definir em detalhes quais jornais seriam incluídos no estudo, qual o período de análise, quantas colunas seriam analisadas e que aspectos de conteúdo seriam observados”. A partir das importantes definições destacadas pela autora, que correspondem à subetapa amostragem (Krippendorff, 2004), preferimos, diferentemente da ordem sugerida na Figura 11, apresentar, primeiro, critérios que delineiam a constituição do corpus da análise de conteúdo jornalístico - no caso, a seleção dos infovis - para então elucidar a subetapa unitização, referente à definição das unidades analíticas.

\subsection{AMOSTRAGEM}

\subsubsection{Escolha dos sítios jornalísticos}

Os veículos de comunicação escolhidos foram The New York Times, The Guardian, Folha de S. Paulo, O Estado de S. Paulo. A decisão de estudar duas publicações estrangeiras e duas publicações brasileiras, embora não parta de objetivo comparativo central em nossa pesquisa, propicia contexto investigativo precursor em estudo de infovis e possibilita estabelecer etapas de desenvolvimento em sua produção. Isso explicitado, a escolha dos veículos citados se deve às seguintes razões: 1) credibilidade e repercussão já estabelecida de suas publicações; 2) acesso eficaz e gratuito aos conteúdos on-line e 3) destaque pioneiro, no caso do cenário internacional, 
e precursor no Brasil, no caso do cenário nacional, na produção de infovis. Sobre este último fator, destacamos que, para Cairo (2008, p. 60), o veículo The New York Times é, no momento, líder na produção do que o autor denomina infográficos de corrente analítica, ou seja, infográficos que utilizam base de dados e/ou técnicas e ferramentas de representação oriundas da visualização da informação. The Guardian destaca-se na produção de infovis com premiações no Malofiej Awards ${ }^{2}$ e no Data Journalism Awards ${ }^{3}$ concursos que evidenciam as melhores produções de infográficos jornalísticos, impressos e on-line, do mundo todo. No Brasil, o reconhecimento das produções infográficas em sítios jornalísticos é, comparativamente, mais recente e singelo. No entanto, destacamos os veículos Folha de S. Paulo e O Estado de S. Paulo, pois, além de suas credibilidades e tradições já estabelecidas, figuram em primeiro e terceiro lugar, respectivamente, no ranking de jornais brasileiros de circulação geral paga (impressa e digital), segundo pesquisa do IVC $^{4}$ relativa ao ano de 2013, que reajustou regras para cálculo da audiência de jornais na internet. ${ }^{5}$ Acrescente-se ainda que essas publicações brasileiras possuem títulos em premiações de produção infográfica nacional (Infolide ${ }^{6}$ ) e internacional (Malofiej Awards). Vale ainda elucidar que propomos, inicialmente, inclusão de um quinto veículo jornalístico, o sítio do jornal O Globo, segundo lugar no ranking da pesquisa citada. No entanto, durante processo de busca manual e sistematizada de infovis dessa publicação, notamos três inconsistências metodológicas que inviabilizaram sua presença na amostragem. Primeiramente, produtos infográficos do sítio não possuem marcas textuais de data. Nem mesmo a $\mathrm{URL}^{7}$ das páginas referencia dia, mês ou ano em que infográficos são publicados. A publicação passou por grande reforma gráfico-editorial em 2011, modificando seus veículos impressos e online. Durante esse processo, a URL da página principal do sítio foi modificada de <oglobo2.globo.com> para <oglobo.globo.com> e todas as páginas com URLs antigos deixaram de existir. O processo de mudança de URL em sítios jornalísticos prevê,

\footnotetext{
${ }^{2}$ Malofiej Awards é apontado como a mais importante premiação mundial para infografia jornalística.

${ }^{3}$ Data Journalism Awards é um concurso internacional que premia os melhores projetos em jornalismo de dados dos quais muitos se enquadram como infovis. Em 2014, o concurso chega à terceira edição como premiação pioneira e especializada nesse segmento.

${ }^{4}$ Instituto Verificador de Circulação.

${ }^{5}$ A informação é do sítio Observatório da Imprensa (Disponível em: <http://www.observatoriodaimprensa.com.br/ news/view/uma_festa_imodesta>. Acesso em fev. 2014).

${ }^{6}$ Infolide corresponde à versão nacional do Malofiej Awards.

${ }^{7}$ Uniform Resource Locator (URL), em português Localizador-Padrão de Recursos, é o endereço de um recurso disponível em rede.
} 
normalmente, migração das páginas antigas para páginas novas, mas notamos, no entanto, que muitas páginas não foram migradas até o momento da seleção do nosso corpus, incluindo as que continham infovis. Por último, a seção geral de infográficos do sítio reformulado de $O$ Globo configura seleção bastante reduzida de suas peças e não funciona como referência para constituir uma amostra sistematizada de infovis, como ocorre nos outros quatro sítios mencionados.

\subsubsection{Escolha do período de análise}

O recorte analítico do corpus no período entre janeiro de 2010 e dezembro de 2013 deve-se ao fato de esses quatro anos compreenderem a produção de infovis relativos a pelo menos uma eleição presidencial nos países sedes de suas respectivas publicações: 1) The New York Times, Estados Unidos, 2012; 2) The Guardian, Reino Unido, 2010 3) Folha de S. Paulo e O Estado de S. Paulo, Brasil, 2010 e 2013. Além disso, a abrangência de quatro anos nos oferece recorte adequado para coleta de número relevante de infovis (precisamente, 270 peças) dentro do cronograma de dissertação de mestrado, de trinta meses. Nesse sentido, é importante destacar que o levantamento do corpus gerou minuciosa busca de infovis aplicáveis a nosso recorte de pesquisa nos sítios jornalísticos e web.

\subsubsection{Escolha da categoria de conteúdo analisada}

Entendemos o termo editoria como “[...] cada uma das seções de uma empresa editorial, de um órgão de imprensa, de uma obra de referência etc., sob a responsabilidade de um editor especializado" (RABAÇA; BARBOSA, 1987, p. 1750). Sendo assim, exemplos comuns de editoria são Política, Economia, Esportes, Cultura, etc. No entanto, como a rotulação de editorias e suas respectivas abrangências temáticas dependem de decisões editoriais, a busca de produtos mediáticos sobre determinando assunto, em diferentes veículos jornalísticos, a partir de nomes específicos de editoria pode resultar em procedimento inconsistente. Por exemplo, a reportagem sobre ataque militar norte-americano na Síria pode ser exposta, em jornal brasileiro, dentro da editoria Internacional; em jornal norte-americano, 
dentro da editoria Política; em jornal sírio, dentro da editoria Cidades. Ou ainda, um mesmo veículo jornalístico pode publicar informações sobre gastos orçamentários do governo na editoria Economia, sendo que o assunto também é político, e publicar notícias sobre manifestações e protestos na editoria Política, sendo que o tema é essencialmente de cobertura de cidades. Em todos os casos, articulam-se questões de contexto, ênfase noticiosa e escolha editorial. Nesta dissertação, em vez de nos atermos a uma editoria específica para seleção da amostragem, procedemos por meio de seleção semântica, escolhendo infovis que se enquadrem na categoria de conteúdo político, uma vez que notícias e reportagens sobre essa temática podem envolver extensas, complexas e diversas redes de dados quantitativos e categóricos de interesse público.

Quando estruturada por prática jornalística guiada para evidenciação de relações - quantitativas, temporais, geográficas, grupais, conectivas - entre dados, a cobertura política oferece excelente cenário para observar produção de infovis que concebem formas de refletir por meio de relações, comparações, evoluções, simultaneidades, etc., destacando a contribuição da visualização da informação para o processo comunicativo e para a aquisição de conhecimento.

O jornalismo político pode ser definido como a "[...] prática especializada em informar sobre campanhas políticas, eleições e funções governamentais” (MILLSBROWN, 2008, p. 297). Devido à posição intermediária entre elite política e cidadãos, as principais expectativas a respeito dos jornalistas políticos podem ser resumidas em quatro premissas: 1) têm o dever de proporcionar aos cidadãos informações que lhes permitam fazer parte da democracia deliberativa; 2) devem servir como fiscais do governo, divulgando maus comportamentos e irregularidades; 3) devem servir como mediadores e representantes dos cidadãos, garantindo que a voz do povo seja ouvida e 4) podem ser participantes do processo político e defender posições políticas particulares (MCNAIR, 2009, p. 239).

As pautas do jornalismo político incluem cobertura de eventos (eleições, revoluções, golpes, votações parlamentares, decretos, negociações entre partidos e blocos de poder e inúmeros outros), as instituições que geram produtos e fatos (governos, ministérios, secretarias, partidos, órgãos oficiais, institutos de pesquisa de opinião), as políticas públicas (ministérios da área institucional, secretarias de 
governo) e o dia a dia do poder. Nesses assuntos do cotidiano incluem-se: negociações, acordos e trâmites de projetos de lei, mudanças de cargos, processos contra políticos e ocupantes de cargos públicos, além de escândalos de crimes políticos, abuso de poder, tráfico de influência e corrupção.

Com base na definição de jornalismo político (MILLS-BROWN, 2008) e nas premissas referentes a seu exercício (MCNAIR, 2009) é possível estabelecer uma gama de pautas envolvidas nesse campo específico do Jornalismo. Nesse sentido, visando estabelecer parâmetros para seleção do corpus, uma vez que decidimos não filtrar infovis pelas editorias rotuladas pelas publicações jornalísticas, mas sim pelo o que julgamos constituir categoria de conteúdo político, definimos as seguintes temáticas do jornalismo político aos quais infovis devem submeter-se:

- tema 1: cobertura de eventos eleitorais (resultados, pesquisas, cenários, debates, previsões, candidatos, eleitorado, campanha e coligações);

- tema 2: instituições políticas que geram produtos e fatos (governo e governantes, Congresso Nacional, ministérios, assembleias legislativas, secretarias, partidos, órgãos oficiais, institutos de pesquisa de opinião);

- tema 3: escândalos políticos e casos de corrupção.

Com exceção da cobertura de eleições, que ajuizamos oportuno selecionar em nível local, regional, nacional e internacional, optamos por restringir infovis relativos aos demais eixos temáticos a eventos e acontecimentos de âmbito nacional, ou seja, diretamente relativos aos países das publicações em questão. Dessa forma, encontramos uma forma de filtrar, de nosso corpus, peças com ênfase semântica mais próxima da cobertura internacional do que da política.

\subsubsection{Delimitação do corpus}

De acordo com referências discutidas no Capítulo 2, infovis é um produto midiático do jornalismo on-line que se caracteriza por ser, simultaneamente:

- um infográfico, pois, como produto do jornalismo visual, possui características narrativas, funções informativas e elementos estruturais típicos do gênero jornalístico; 
- uma visualização da informação, pois apresenta, mesmo que parcialmente, ${ }^{8}$ organização e apresentação visual baseada em dados e representa as relações estabelecidas entre eles;

- interativo, pois oferece ao usuário mecanismos de interação com o conteúdo.

Definidos os três critérios que delineiam a constituição de nosso corpus (veículo, período e categoria de análise), foi necessário realizar, em cada um dos quatro sítios jornalísticos, processo de busca manual e sistematizada de infovis dentro de nosso recorte. Enfatizamos que faz parte de nosso interesse investigativo analisar infovis com diversos níveis de complexidade de produção: desde peças com maior grau de planejamento, conhecimentos técnicos, envolvimento de diversos profissionais e premiação em concursos de infografia até peças com menor investimento produtivo, que passam despercebidas dos olhares de estudiosos e especialistas. Relatamos, a seguir, o procedimento de busca para cada sítio jornalístico e apresentamos as peças.

\section{The New York Times}

O sítio The New York Times (NYT) possui seção de produtos multimídia9 que pode ser acessada por sua página inicial. A seção apresenta destaques de conteúdos audiovisuais - entre fotogalerias, vídeos, podcasts, infográficos estáticos e infográficos interativos - das diferentes editorias do jornal (World, U.S., Business, Health, etc.), mas não possui opção de busca que permita filtrar apenas infográficos interativos por ano e por assunto. Diante da extensa produção infográfica da publicação, a seleção de infovis em seu sítio mostrou-se insuficiente para nossos propósitos.

No entanto, o acesso randômico a exemplos de infográficos interativos do sítio NYT, por meio do twitter $^{10}$ da publicação e outros sítios ${ }^{11}$ e $b_{\operatorname{logs}}{ }^{12}$ que propõem reunir e

\footnotetext{
${ }^{8}$ Destacamos o fato de que infovis para ser considerado como tal deve evidenciar a incorporação de elementos de organização e apresentação visual oriundos das técnicas da visualização da informação no infográfico. No entanto, o infovis pode apresentar, simultaneamente, outras modalidades de organização visual e elementos figurativos como fotos, vídeos e animações.

${ }^{9}$ Disponível em: <http://www.nytimes.com/pages/multimedia/index.html>. Acesso em: dez. 2013.

${ }^{10}$ Disponível em: <https://twitter.com/nytgraphics $>$. Acesso em: dez. 2013.

11 Disponível em: <http://visualoop.com/br>; <http://flowingdata.com>; <http://www.interactive-infogra phics.com>; <http://collection.marijerooze.nl>; <http://www.smallmeans.com/new-york-times-infographics $>$. Acesso em: dez. 2013.

${ }^{12}$ Disponível em: <http://infografiaembasededados.wordpress.com>; <http://noticiasvisuais.wordpress.com>; <http://infographicsnews.blogspot.com.br>. Acesso em: dez. 2013.
} 
destacar produções infográficas de publicações jornalísticas, nos permitiu notar certa similaridade na nomenclatura dos endereços das páginas (URL) originais do sítio The New York Times, em que se encontram infovis. Na maioria das vezes, o endereço de página dos infovis selecionados inicia-se com o caminho <http://www. nytimes.com/interactive $>$. Dessa forma, foi possível realizar busca refinada com ferramentas avançadas do Google por todas as páginas da web que se iniciam com o endereço <http://www.nytimes.com/interactive>, publicadas entre 2010 e 2013.

O sítio NYT reserva endereços de páginas diferenciadas para coberturas de eventos e desenvolvimento de produtos que sejam julgados especiais. Dessa forma, localizamos infovis, referenciados em sítios e blogs, com endereços originais iniciados com outros caminhos, a saber: <http://elections.nytimes.com/2010>; <http://elections. nytimes.com/2012>; <http://projects.nytimes.com>; <http://www.nytimes.com/projects /elections $>$; <http://www.nytimes.com/newsgraphics $>$ e $<$ http://politics.nytimes.com/ congress $>$. Para esses endereços repetimos o processo de busca refinada por data, no Google. Ao final do processo de busca, selecionamos 81 infovis pertencentes ao NYT, que estão relacionados no Quadro 11: ${ }^{13}$

Quadro 11 - Relação da amostra de infovis do The New York Times

\begin{tabular}{|llrr|}
\hline ID & Título & Editoria & Ano \\
\hline NYT_1301 & The Factions in the House of Representatives & Politics & 2013 \\
NYT_1302 & Americans on Syria and Iran & World & 2013 \\
NYT_1303 & How Much the N.Y.C. Mayoral Candidates Have Raised and Spent & N.Y./Region & 2013 \\
NYT_1304 & Democratic Voters on the Candidates & N.Y./Region & 2013 \\
NYT_1305 & Polling on the Mayor's Race & N.Y./Region & 2013 \\
NYT_1306 & The Formula Behind the Voting Rights Act & U.S. & 2013 \\
NYT_1307 & Electronic Surveillance Under Bush and Obama & U.S. & 2013 \\
NYT_1308 & The Scale of the President's Budget & Politics & 2013 \\
NYT_1309 & Women in the Senate & Politics & 2013 \\
NYT_1310 & Tracking the Mayoral Candidates Across New York City & N.Y./Region & 2013 \\
NYT_1311 & Americans on Domestic Policy & U.S. & 2013 \\
NYT_1312 & Americans on Terrorism Threat & U.S. & 2013 \\
NYT_1313 & The Mayoral Primaries & Projects & 2013 \\
NYT_1314 & City Council & Projects & 2013 \\
NYT_1315 & The Comptroller Primary & Projects & 2013 \\
NYT_1316 & New York City Mayor & Projects & 2013 \\
NYT_1317 & City Council & Projects & 2013 \\
NYT_1318 & New York State Ballot Measures & Projects & 2013 \\
& &
\end{tabular}

\footnotetext{
${ }^{13}$ A versão digital do Quadro 11, em CD, contém hyperlinks para página web de cada infovis.
} 


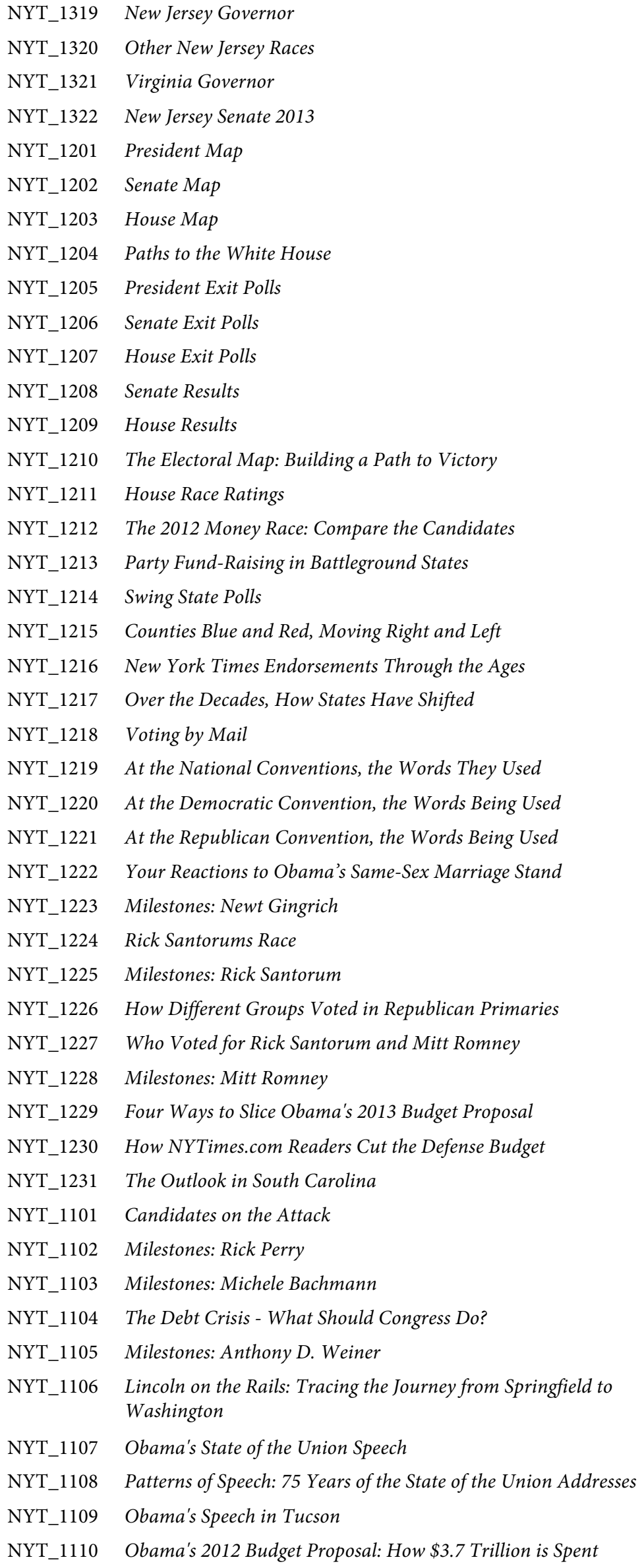

\begin{tabular}{|c|c|}
\hline Projects & 2013 \\
\hline Projects & 2013 \\
\hline Projects & 2013 \\
\hline Projects & 2013 \\
\hline Elections 2012 & 2012 \\
\hline Elections 2012 & 2012 \\
\hline Elections 2012 & 2012 \\
\hline Elections 2012 & 2012 \\
\hline Elections 2012 & 2012 \\
\hline Elections 2012 & 2012 \\
\hline Elections 2012 & 2012 \\
\hline Elections 2012 & 2012 \\
\hline Elections 2012 & 2012 \\
\hline Elections 2012 & 2012 \\
\hline Elections 2012 & 2012 \\
\hline Elections 2012 & 2012 \\
\hline Elections 2012 & 2012 \\
\hline Politics & 2012 \\
\hline Sunday-Review & 2012 \\
\hline The Opinion Pages & 2012 \\
\hline Politics & 2012 \\
\hline U.S. & 2012 \\
\hline Politics & 2012 \\
\hline Politics & 2012 \\
\hline Politics & 2012 \\
\hline Politics & 2012 \\
\hline Politics & 2012 \\
\hline U.S. & 2012 \\
\hline Politics & 2012 \\
\hline Politics & 2012 \\
\hline Politics & 2012 \\
\hline Politics & 2012 \\
\hline Politics & 2012 \\
\hline 7 & 2012 \\
\hline U.S. & 2012 \\
\hline Politics & 2011 \\
\hline Politics & 2011 \\
\hline Politics & 2011 \\
\hline Politics & 2011 \\
\hline N.Y./Region & 2011 \\
\hline The Opinion Pages & 2011 \\
\hline Politics & 2011 \\
\hline Politics & 2011 \\
\hline Politics & 2011 \\
\hline Politics & 2011 \\
\hline
\end{tabular}




\begin{tabular}{|llrr|} 
NYT_1001 & Governor Map & Elections 2010 & 2010 \\
NYT_1002 & House Map & Elections 2010 & 2010 \\
NYT_1003 & Senate Map & Elections 2010 & 2010 \\
NYT_1004 & House Big Board & Elections 2010 & 2010 \\
NYT_1005 & Senate Big Board & Elections 2010 & 2010 \\
NYT_1006 & Governor Exit Polls & Elections 2010 & 2010 \\
NYT_1007 & House Exit Polls & Elections 2010 & 2010 \\
NYT_1008 & Senate Exit Polls & Elections 2010 & 2010 \\
NYT_1009 & The Election Will Be Tweeted (and Retweeted) & Politics & 2010 \\
NYT_1010 & The 2010 Republican Comeback: How It Developed & Politics & 2010 \\
NYT_1011 & What One Word Describes Your Current State of Mind? & Politics & 2010 \\
NYT_1012 & Census 2010: Gains and Losses in Congress & U.S. & 2010 \\
NYT_1013 & Budget Puzzle: You Fix the Budget & Week in Review & 2010 \\
NYT_1014 & A Banner Year for Political Spending & Projects & 2010 \\
NYT_1015 & Support for Same-Sex Marriage & Week in Review & 2010 \\
NYT_1016 & As Reform Falters, Immigration Battle Rages in Arizona & Opinion & 2010 \\
NYT_1017 & Obama's 2011 Budget Proposal: How Its Spent & U.S. & 2010 \\
NYT_1018 & Analyzing President Obama's First State of the Union Address & Politics & 2010 \\
\hline
\end{tabular}

Fonte: elaboração própria.

\section{The Guardian}

Diferentemente do sítio do NYT, a seção multimídia ${ }^{14}$ do The Guardian (TGU) agrupa seus conteúdos audiovisuais em categorias, dentre as quais se destaca Interactive Guides, ${ }^{15}$ que reúne produtos midiáticos interativos da publicação. Na seção específica de conteúdos interativos é possível, ainda, filtrá-los per editorias e visualizá-los em ordem de publicação. Dessa forma, analisamos e selecionamos, a partir dos procedimentos de amostragem, infovis referentes às editorias Business, Politics, Society, UK News, World News (Negócios, Política, Sociedade, Notícias nacionais e Notícias Internacionais). $\mathrm{O}$ processo de identificação e seleção de peças do TGU foi, consideravelmente, mais rápido do que o ocorrido no sítio do NYT, resultando em 65 infovis que estão relacionados no Quadro 12:16

\footnotetext{
${ }^{14}$ Disponível em: <http://www.theguardian.com/multimedia $>$. Acesso em jan. 2014.

${ }^{15}$ Disponível em: <http://www.theguardian.com/interactive>. Acesso em jan. 2014.

${ }^{16}$ A versão digital do Quadro 12 , em CD, contém hyperlinks para página web de cada infovis.
} 
Quadro 12 - Relação da amostra de infovis do The Guardian

\begin{tabular}{|c|c|c|c|}
\hline ID & Título & Editoria & Ano \\
\hline TGU_1301 & Voter apathy 1964-2010: What's changed? & Datablog & 2013 \\
\hline TGU_1302 & Which countries let prisoners vote? Interactive map & Datablog & 2013 \\
\hline TGU_1303 & Ed Miliband's speech to the Labour party conference - live stream & Politics & 2013 \\
\hline TGU_1304 & MPs' expenses 2012/13: every claim for accommodation, travel and more & Datablog & 2013 \\
\hline TGU_1305 & Labour party finances: then and now & Datablog & 2013 \\
\hline TGU_1306 & Australian election 2013: live results & World & 2013 \\
\hline TGU_1307 & Campaign watch: 2013 Australian election interactive map & World & 2013 \\
\hline TGU_1308 & Zimbabwe election results: interactive map & Datablog & 2013 \\
\hline TGU_1309 & Spending review 2013 interactive & Datablog & 2013 \\
\hline TGU_1310 & Local elections 2013: results mapped & Datablog & 2013 \\
\hline TGU_1311 & Margaret Thatcher's Britain - an interactive presentation & Politics & 2013 \\
\hline TGU_1312 & Council spending cuts across the UK - interactive map & Society & 2013 \\
\hline TGU_1313 & Balancing the budget - interactive guide & UK News & 2013 \\
\hline TGU_1314 & Eastleigh byelection voting intention polls & Datablog & 2013 \\
\hline TGU_1315 & Italian election results: an interactive guide & Datablog & 2013 \\
\hline TGU_1316 & Gay marriage bill: how did your MP vote? Map & Datablog & 2013 \\
\hline TGU_1317 & Gun laws in the US, state by state - interactive & World & 2013 \\
\hline TGU_1201 & The corruption map of the world & Datablog & 2012 \\
\hline TGU_1202 & $\begin{array}{l}\text { Public spending by UK government department 2011-12: } \\
\text { an interactive guide }\end{array}$ & Datablog & 2012 \\
\hline TGU_1203 & US elections 2012: the battleground states - interactive & World & 2012 \\
\hline TGU_1204 & You decide the 2012 US presidential election & World & 2012 \\
\hline TGU_1205 & Obama-Romney foreign policy debate: Mapping the mentions - interactive & World & 2012 \\
\hline TGU_1206 & US presidential election fundraising: help us explore the FEC data & Datablog & 2012 \\
\hline TGU_1207 & $\begin{array}{l}\text { Interactive - Venezuelan election results mapped for every public } \\
\text { vote since Chavez took power }\end{array}$ & Datablog & 2012 \\
\hline TGU_1208 & $\begin{array}{l}\text { RNC 2012: The American dream, family, Obama and Romney - the } \\
\text { language used at the Republican National Convention's speeches }\end{array}$ & Datablog & 2012 \\
\hline TGU_1209 & Culture cuts: where austerity measures are curtailing the arts -map & Culture & 2012 \\
\hline TGU_1210 & The police cuts map of England and Wales & Datablog & 2012 \\
\hline TGU_1211 & $\begin{array}{l}\text { How did the Greek vote vary by region and party? Explore every } \\
\text { detail with this interactive visualisation }\end{array}$ & Datablog & 2012 \\
\hline TGU_1212 & Queen's diamond jubilee: $£ 32 m$, the cost of the monarchy-interactive & Datablog & 2012 \\
\hline TGU_1213 & Egypt elections - the candidates & World & 2012 \\
\hline TGU_1214 & London mayoral election: the votes mapped, ward by ward & Datablog & 2012 \\
\hline TGU_1215 & Gay rights in the US, state by state & World & 2012 \\
\hline TGU_1216 & London mayoral election 2008: how the city voted, mapped & Datablog & 2012 \\
\hline TGU_1217 & Budget 2012: UK income and expenditure - interactive & Business & 2012 \\
\hline TGU_1218 & Republican delegate count 2012: a guide to the candidates' momentum & World & 2012 \\
\hline TGU_1219 & Do you think Scotland should become independent? & Politics & 2012 \\
\hline TGU_1101 & Egyptian elections: the parties and where they stand - interactive & World & 2011 \\
\hline TGU_1102 & Public spending by UK government department: an interactive guide & Datablog & 2011 \\
\hline TGU_1103 & Would you describe yourself as British? & UK News & 2011 \\
\hline TGU_1104 & Liam Fox and Adam Werritty: the web of connections - interactive & Politics & 2011 \\
\hline TGU_1105 & Phone-hacking scandal: Who's who - interactive & Media & 2011 \\
\hline
\end{tabular}




\begin{tabular}{|c|c|c|c|}
\hline TGU_1106 & How UK parliamentary constituencies could change - interactive guide & Politics & 2011 \\
\hline TGU_1107 & $\begin{array}{l}\text { A year in the life of the Conservative-Liberal Democrat coalition- } \\
\text { interactive timeline }\end{array}$ & Politics & 2011 \\
\hline TGU_1108 & AV referendum: who supports which side & Politics & 2011 \\
\hline TGU_1109 & Budget 2011: The state of Britain's finances & UK News & 2011 \\
\hline TGU_1001 & Council spending cuts: interactive map & Society & 2010 \\
\hline TGU_1002 & Government spending: What happens to our money? & Politics & 2010 \\
\hline TGU_1003 & Corruption index 2010: the most corrupt countries in the world & Global Development & 2010 \\
\hline TGU_1004 & Live election results map for the US midterms & World & 2010 \\
\hline TGU_1005 & UK public spending since 1948 & Politics & 2010 \\
\hline TGU_1006 & Coalition policies: Which party is winning? & Politics & 2010 \\
\hline TGU_1007 & Public sector expenditure & Politics & 2010 \\
\hline TGU_1008 & UK voting intentions & Politics & 2010 \\
\hline TGU_1009 & Budget 2010: Analysing George Osborne's speech & UK News & 2010 \\
\hline TGU_1010 & Which parties could form a coalition government? & Politics & 2010 \\
\hline TGU_1011 & Election 2010: voting problems & Politics & 2010 \\
\hline TGU_1012 & Election map and swingometer & Politics & 2010 \\
\hline TGU_1013 & General election 2010: opinion poll calculator & Politics & 2010 \\
\hline TGU_1014 & Election 2010: Third TV debate poll tracker & Politics & 2010 \\
\hline TGU_1015 & Election 2010: Second TV debate poll tracker & Politics & 2010 \\
\hline TGU_1016 & Election 2010: TV debate poll tracker & Politics & 2010 \\
\hline TGU_1017 & Mapping the 2010 election & Comment is free & 2010 \\
\hline TGU_1018 & Election 2010: Which are the safest seats in Britain? & Politics & 2010 \\
\hline TGU_1019 & General election 2010: poll of polls & Politics & 2010 \\
\hline TGU_1020 & Budget 2010: reaction from around the UK & UK News & 2010 \\
\hline
\end{tabular}

Fonte: elaboração própria.

\section{Folha de S. Paulo}

O sítio Folha de S. Paulo (FSP) possui seção de especiais ${ }^{17}$ e de infográficos, ${ }^{18}$ Uma busca nessas seções permitiu identificar grande parte dos infovis que constituem o corpus referente a essa publicação. No entanto, notou-se que ambas as seções tratam de seleções e não reúnem todos os infovis do sítio, principalmente aqueles mais antigos, publicados entre 2010 e 2012. Por meio de algumas peças coletadas, entretanto, foi possível notar padrões de URL como: 1) <http://www1.folha.uol.com.br/infograficos> e 2) <http://folhaspdados.blogfolha.uol.com.br>, para infovis publicados pelo projeto FolhaSPDados,${ }^{19}$ Para esses endereços, repetimos o processo de busca refinada por data

\footnotetext{
${ }^{17}$ Disponível em: <http://www1.folha.uol.com.br/infograficos >. Acesso em: fev. 2014.

${ }^{18}$ Disponível em: <http://www1.folha.uol.com.br/infograficos>. Acesso em: fev. 2014.

${ }^{19}$ FolhaSPDados: Para visualizar, analisar e compartilhar dados é um projeto da Folha de S. Paulo em parceria com Knight International Journalism Fellowships, do Centro Internacional para Jornalistas, com objetivo de criar infográficos interativos para analisar e visualizar informação.
} 
no Google, o que proporcionou a identificação de novos infovis. As 50 peças pertencentes à publicação FSP estão relacionadas no Quadro 13: ${ }^{20}$

Quadro 13 - Relação da amostra de infovis da Folha de S. Paulo

\begin{tabular}{|c|c|c|c|}
\hline ID & Título & Editoria & Ano \\
\hline FSP_1301 & Cenários para 2014 & Poder & 2013 \\
\hline FSP_1302 & Por dentro do 39 "ministério" de Dilma & Dinheiro público \& cia & 2013 \\
\hline FSP_1303 & Fim da linha & Poder & 2013 \\
\hline FSP_1304 & A Explosão dos Programas Sociais & Dinheiro público \& cia & 2013 \\
\hline FSP_1305 & As principais privatizações de cada presidente & Dinheiro público \& cia & 2013 \\
\hline FSP_1306 & A hora da prisão & Poder & 2013 \\
\hline FSP_1307 & O mapa-mundo das contas públicas & Dinheiro público \& cia & 2013 \\
\hline FSP_1308 & A História das Constituições no Brasil & Poder & 2013 \\
\hline FSP_1309 & Soltando o dinheiro & Poder & 2013 \\
\hline FSP_1310 & Um novo cenário & Poder & 2013 \\
\hline FSP_1311 & Confira quantas vezes a Carta cita algumas palavras & Poder & 2013 \\
\hline FSP_1312 & O aumento dos gastos públicos com a educação & Mercado & 2013 \\
\hline FSP_1313 & Como é gasto o dinheiro dos impostos & Dinheiro público \& cia & 2013 \\
\hline FSP_1314 & Ministérios Com Mais Cargos de Livre Nomeação & Mercado & 2013 \\
\hline FSP_1315 & A recuperação de Dilma & Poder & 2013 \\
\hline FSP_1316 & Datafolha, 30 & Poder & 2013 \\
\hline FSP_1317 & Uma nova chance & Poder & 2013 \\
\hline FSP_1201 & Votação versus arrecadação & O Custo do Voto & 2012 \\
\hline FSP_1202 & Linha do tempo & O Custo do Voto & 2012 \\
\hline FSP_1203 & $\begin{array}{l}\text { Cartograma: os partidos ganhadores de acordo com } \\
\text { o tamanho do eleitorado }\end{array}$ & FolhaSPDados & 2012 \\
\hline FSP_1204 & $\begin{array}{l}\text { Haddad vira em oito zonas eleitorais em que havia perdido } \\
\text { no primeiro turno }\end{array}$ & FolhaSPDados & 2012 \\
\hline FSP_1205 & O mapa do voto no Brasil & Eleições 2012 & 2012 \\
\hline FSP_1206 & Corrida eleitoral em São Paulo & Eleições 2012 & 2012 \\
\hline FSP_1207 & Evolução dos partidos & Eleições 2012 & 2012 \\
\hline FSP_1208 & Pilote o Folhacóptero & Eleições 2012 & 2012 \\
\hline FSP_1209 & Promessômetro & Especial & 2012 \\
\hline FSP_1210 & $\begin{array}{l}\text { Datafolha: Serra só vence entre eleitores com renda superior a } \\
10 \text { salários mínimos }\end{array}$ & FolhaSPDados & 2012 \\
\hline FSP_1211 & Se votassem, imigrantes poderiam decidir eleição em $S P$ & FolhaSPDados & 2012 \\
\hline FSP_1212 & Datafolha: Serra só ganha entre eleitores com mais de 60 anos & FolhaSPDados & 2012 \\
\hline FSP_1213 & $\begin{array}{l}\text { Apoio de pastores não dá vitória a Serra em distritos mais } \\
\text { evangélicos }\end{array}$ & FolhaSPDados & 2012 \\
\hline FSP_1214 & Mapa interativo dos compromissos de campanha & FolhaSPDados & 2012 \\
\hline FSP_1215 & $\begin{array}{l}\text { Painel interativo traz os últimos resultados da corrida eleitoral } \\
\text { em SP }\end{array}$ & FolhaSPDados & 2012 \\
\hline FSP_1216 & $\begin{array}{l}\text { Prévias acirram disputa presidencial de } 2012 \text { nos EUA; veja } \\
\text { calendário }\end{array}$ & Mundo & 2012 \\
\hline
\end{tabular}

A versão digital do Quadro 13, em CD, contém hyperlinks para página web de cada infovis. 


$\begin{array}{|llrr|}\text { FSP_1217 } & \text { O caminho do dinheiro } & \text { Poder } & 2012 \\ \text { FSP_1218 } & \text { Quem é quem } & \text { Poder } & 2012 \\ \text { FSP_1219 } & \text { O esquema } & \text { Poder } & 2012 \\ \text { FSP_1220 } & \text { Mapa de apuração } & \text { Mundo } & 2012 \\ \text { FSP_1101 } & \text { Dia a dia da presidente } & \text { Poder } & 2011 \\ \text { FSP_1001 } & \text { Oito anos em números, um balanço do governo Lula } & \text { Poder } & 2010 \\ \text { FSP_1002 } & \text { Confira o mapa dos governos estaduais eleitos este ano } & \text { Poder } & 2010 \\ \text { FSP_1003 } & \text { Veja o novo mapa do Congresso e conheça a distribuição } & \text { Poder } & 2010 \\ & \text { partidária } & \text { Poder } & 2010 \\ \text { FSP_1004 } & \text { Relembre a campanha presidencial em um minuto } & \text { Poder } & 2010 \\ \text { FSP_1005 } & \text { Avaliação do governo Lula } & \text { Poder } & 2010 \\ \text { FSP_1006 } & \text { Candidatos à Presidência }-1^{\circ} \text { turno } & \text { Poder } & 2010 \\ \text { FSP_1007 } & \text { Candidatos à Presidência }-2^{\circ} \text { turno } & \text { Poder } & 2010 \\ \text { FSP_1008 } & \text { Candidatos à Governador }-1^{\circ} \text { turno } & \text { Poder } & 2010 \\ \text { FSP_1009 } & \text { Candidatos à Governador }-2^{\circ} \text { turno } & \text { Poder } & 2010 \\ \text { FSP_1010 } & \text { Apuração por Município } & \text { Poder } & 2010 \\ \text { FSP_1011 } & \text { Promessômetro } & \text { Poder } & 2010 \\ \text { FSP_1012 } & \text { Outras Pesquisas } & & \end{array}$

Fonte: elaboração própria.

\section{O Estado de S. Paulo}

O sítio O Estado de S. Paulo (ESP) possui duas seções on-line em que organiza e disponibiliza infográficos produzidos pela publicação: a primeira, a seção Especiais, ${ }^{21}$ organizada cronologicamente, reúne acervo bastante completo de infográficos e outros produtos audiovisuais (vídeos, podcasts, etc.); a segunda, a seção Estadão Dados ${ }^{22}$ concentra infográficos produzidos para reportagens especiais baseadas em análises e cruzamento de dados estatísticos.

Ao final da busca, selecionamos 74 infovis pertencentes ao ESP que estão relacionados no Quadro 14:23

Quadro 14 - Relação da amostra de infovis de O Estado de S. Paulo

\begin{tabular}{|llrr|}
\hline ID & Título & Editoria & Ano \\
\hline ESP_1301 & Veja quem é mais popular: Dilma ou o governador & Estadão Dados & 2013 \\
ESP_1302 & Dilma abre diferença sobre adversários na corrida presidencial de 2014 & Estadão Dados & 2013 \\
ESP_1303 & Fraude na Prefeitura de São Paulo & Infográficos & 2013 \\
ESP_1304 & Dilma cai para 7 lugar no ranking de presidentes mais aprovados da AL & Estadão Dados & 2013 \\
\hline
\end{tabular}

\footnotetext{
${ }^{21}$ Disponível em: <http://www.estadao.com.br/especiais>. Acesso em fev. 2014.

${ }^{22}$ Nos mesmos moldes do FolhaSPDados, Estadão Dados é um projeto especial do Grupo Estado especializado em reportagens com base em estatísticas e no desenvolvimento de projetos especiais de visualização de dados. A seção está disponível em: <http://blog.estadaodados.com>. Acesso em fev. 2014.

${ }^{23}$ A versão digital do Quadro 14, em CD, contém hyperlinks para página web de cada infovis.
} 


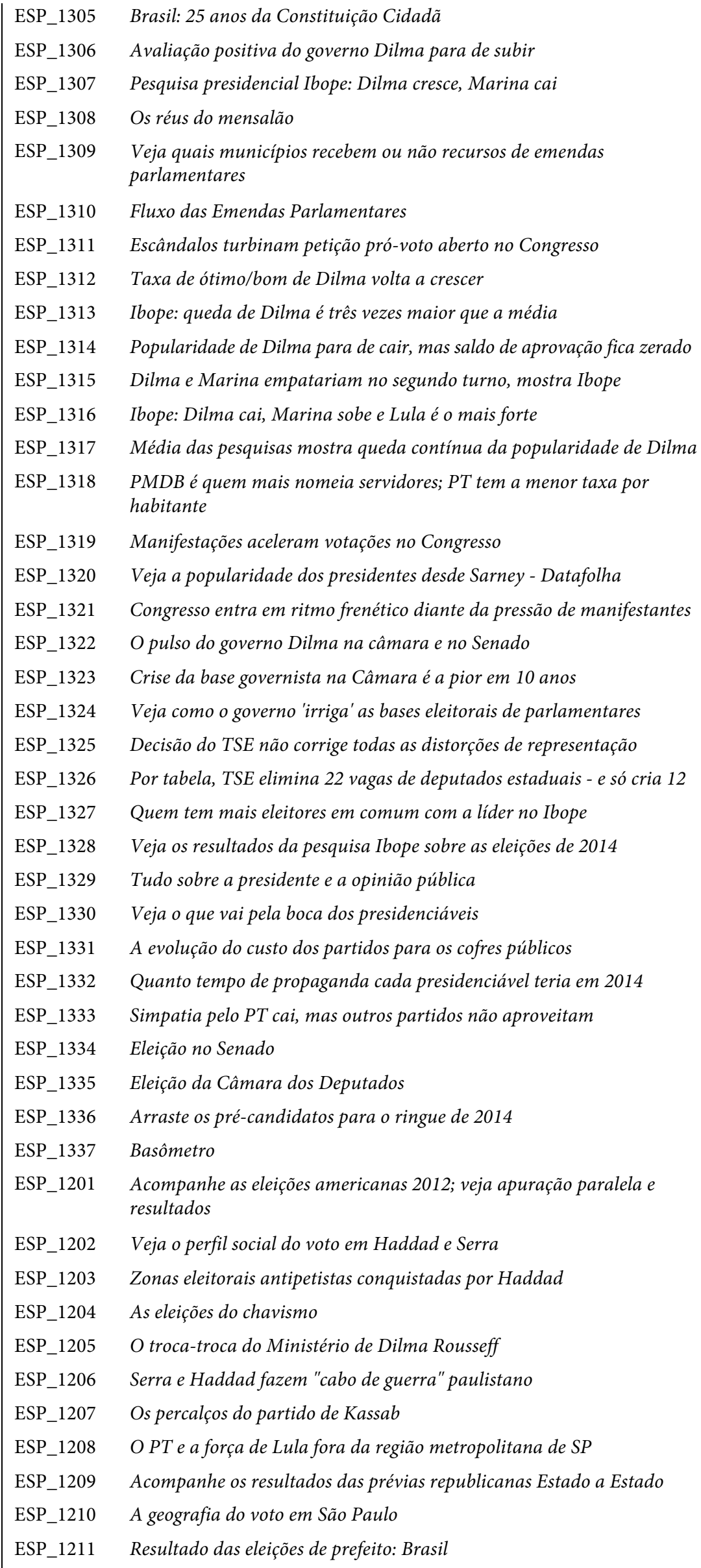

\begin{tabular}{|c|c|}
\hline Infográficos & 201 \\
\hline Estadão Dados & 2013 \\
\hline Estadão Dados & 01 \\
\hline Política & 2013 \\
\hline Estadão Dados & 013 \\
\hline Estadão Dados & 2013 \\
\hline Infográficos & 201 \\
\hline Estadão Dados & 013 \\
\hline Estadão Dados & 01 \\
\hline Estadão Dados & 013 \\
\hline Estadão Dados & 013 \\
\hline Estadão Dados & 2013 \\
\hline Estadão Dados & 013 \\
\hline Estadão Dados & 301 \\
\hline Política & 2011 \\
\hline Estadão Dados & 2013 \\
\hline Infográficos & 01 \\
\hline Estadão Dados & 2013 \\
\hline Estadão Dados & 201 \\
\hline Estadão Dados & 01 \\
\hline Estadão Dados & 2013 \\
\hline Estadão Dados & 2013 \\
\hline Estadão Dados & 2013 \\
\hline Estadão Dados & 2013 \\
\hline Estadão Dados & 2013 \\
\hline Estadão Dados & 2010 \\
\hline Estadão Dados & 2013 \\
\hline Estadão Dados & 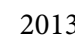 \\
\hline Estadão Dados & 2013 \\
\hline Política & 2013 \\
\hline Política & 2013 \\
\hline Estadão Dados & 2013 \\
\hline Estadão Dados & 2013 \\
\hline Política & 012 \\
\hline Política & 2012 \\
\hline Política & 201 \\
\hline Infográficos & 012 \\
\hline Política & 2012 \\
\hline Política & 2012 \\
\hline Política & 2012 \\
\hline Política & 2012 \\
\hline Infográficos & 2012 \\
\hline Estadão Dados & 2012 \\
\hline Estadão Dados & 2012 \\
\hline
\end{tabular}




\begin{tabular}{|c|c|c|c|}
\hline ESP_1212 & O jogo das coligações & Estadão Dados & 2012 \\
\hline ESP_1101 & As armas do PT para ampliar hegemonia na Grande SP & Política & 2011 \\
\hline ESP_1102 & Os ministros que caíram durante o governo Dilma & Política & 2011 \\
\hline ESP_1103 & A trajetória de Itamar Franco & Política & 2011 \\
\hline ESP_1104 & A trajetória de Marina Silva & Política & 2011 \\
\hline ESP_1105 & A trajetória de José Alencar & Política & 2011 \\
\hline ESP_1106 & Quem é quem nos conselhos das empresas estatais paulistas & Política & 2011 \\
\hline ESP_1107 & A nova Assembleia Legislativa de São Paulo & Política & 2011 \\
\hline ESP_1108 & O novo Congresso Nacional & Política & 2011 \\
\hline ESP_1109 & De Deodoro a Dilma & Política & 2011 \\
\hline ESP_1001 & O $1^{\circ}$ turno na capital paulista, zona a zona & Política & 2010 \\
\hline ESP_1002 & O $2^{\circ}$ turno na capital paulista, zona a zona & Política & 2010 \\
\hline ESP_1003 & O $1^{\circ}$ turno na cidade do Rio de Janeiro, zona a zona & Política & 2010 \\
\hline ESP_1004 & O $2^{\circ}$ turno na cidade do Rio de Janeiro, zona a zona & Política & 2010 \\
\hline ESP_1005 & Geografia do voto & Política & 2010 \\
\hline ESP_1006 & Mapa da votação para presidente nos municípios & Política & 2010 \\
\hline ESP_1007 & Mapa da votação para governador nos Estados & Política & 2010 \\
\hline ESP_1008 & Eleição legislativa nos EUA & Política & 2010 \\
\hline ESP_1009 & As eleições legislativas no Brasil em 2010 & Política & 2010 \\
\hline ESP_1010 & Os resultados das eleições para governador & Política & 2010 \\
\hline ESP_1011 & O tamanho dos partidos no Congresso Nacional & Política & 2010 \\
\hline ESP_1012 & Raio $X$ das eleições parlamentares na Venezuela & Infográficos & 2010 \\
\hline ESP_1013 & A trajetória do ministro do STF Joaquim Barbosa & Infográficos & 2010 \\
\hline ESP_1014 & Viagens dos candidatos à Presidência da República & Política & 2010 \\
\hline ESP_1015 & Ex-promessa política, Ciro é escanteado pelo PSB & Política & 2010 \\
\hline ESP_1016 & Entenda a operação Caixa de Pandora & Infográficos & 2010 \\
\hline
\end{tabular}

Fonte: elaboração própria.

A distribuição de infovis analisados por veículo comunicativo ficou estabelecida conforme a Tabela 1:

Tabela 1 - Distribuição de infovis analisados por veículo de comunicação

\begin{tabular}{cc}
\hline Veículo de comunicação & Número de infovis \\
The New York Times & 81 \\
Folha de S. Paulo & 65 \\
Estado de S. Paulo & 50 \\
Total & 74 \\
\hline
\end{tabular}


Por motivo de limitação de espaço, não apresentamos figuras para os 270 infovis na dissertação impressa. Contudo, criamos quatro galerias de imagens na rede social on-line Pinterest, uma para cada veículo comunicativo, nos quais ilustramos as peças analisadas. As galerias podem ser acessadas nos seguintes hyperlinks: $<$ http://www.pinterest.com/juliagiannella/infovis-the-new-york-times>, <http://www. pinterest.com/juliagiannella/infovis-the-guardian>, <http://www.pinterest.com/julia giannella/infovis-folha-de-s-paulo $>$ e $<$ http://www.pinterest.com/juliagiannella/infoviso-estado-de-s-paulo>.

A Figura 12 exemplifica a galeria de infovis da Folha de S. Paulo disponível na rede social Pinterest.

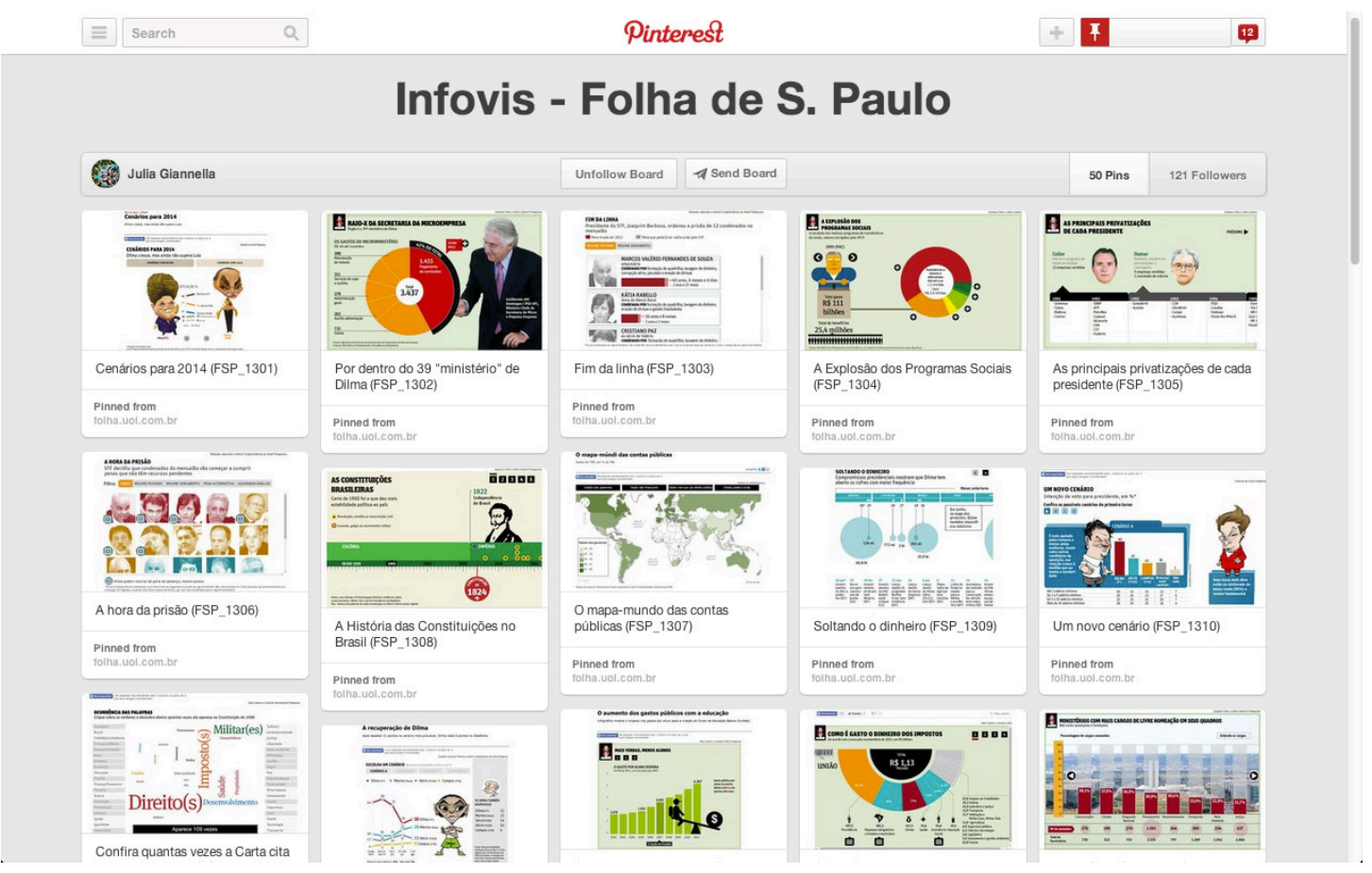

Figura 12 - Galeria de infovis da Folha de S. Paulo. Fonte: Pinterest. ${ }^{24}$

\footnotetext{
${ }^{24}$ Disponível em: <http://www.pinterest.com/juliagiannella/infovis-folha-de-s-paulo/>. Acesso jul. 2014.
} 


\subsection{UNITIZAÇÃO}

“A análise de conteúdo pode ser empregada em estudos exploratórios, descritivos ou explanatórios” (HERSCOVITZ, 2010, p. 127). Em nossa pesquisa, adotamos método predominantemente exploratório, com o objetivo de produzir resultados e inferências sobre um produto particular, o dispositivo infovis, destacando algumas de suas características a partir da leitura da análise.

A unitização, que apresentamos a seguir, implica critérios orientados para responder aos objetivos de nossa pesquisa, que são: 1) em nível específico, obter resultados que possam descrever o cenário produtivo atual de infovis ${ }^{25}$ analisados a partir da articulação de três dimensões que redefinem a infografia como dispositivo interacional no meio digital e on-line: a) input tecnológico; b) interface mediada, por um lado, dos recursos de design e, por outro, do tratamento da comunicação jornalística e c) output interativo e participativo e 2) em âmbito geral, inferir panoramas tendenciais e caminhos futuros que possam ser estendidos para produção de outros dispositivos infovis, oferecendo também apontamentos avançados sobre o estado da arte da infografia jornalística de corrente analítica que acompanha transformações sofridas pelo jornalismo on-line. Resultados e inferências são identificados por meio da leitura sistemática dos dados, realizando-se quantificação e cruzamento de respostas observadas no formulário de análise. ${ }^{26}$ As respostas, por sua vez, são orientadas e tabuladas segundo unidades de análise qualitativas definidas por nós. A combinação operacional de unidades de análise simultaneamente quantitativas e qualitativas promove:

[...] integração entre as duas visões de forma que os conteúdos manifesto (visível) e latente (oculto, subentendido) sejam incluídos em um mesmo estudo para que se compreenda não somente o significado aparente de um texto, mas também o significado implícito, o contexto onde ele ocorre, o meio de comunicação que o produz e o público ao qual ele é dirigido (HERSCOVITZ, 2010, p. 126).

\footnotetext{
${ }^{25}$ Infovis de temática política, publicados entre 2010 e 2013 em quatro sítios jornalísticos (The New York Times, The Guardian, Folha de S. Paulo, O Estado de S. Paulo)

${ }^{26} \mathrm{O}$ formulário de análise preenchido encontra-se no Anexo 1, contido em $\mathrm{CD}$, e na web através do endereço $<$ http://goo.gl/bfQac0 $>$.
} 
A etapa de unitização corresponde à formulação de um protocolo de análise que apresenta e descreve unidades e subunidades elaboradas para analisar infovis coletados, assim como define e caracteriza indicadores de cada subunidade. Dessa forma, o protocolo serve como manual de instrução para preenchimento do formulário de análise que corresponde à fase de codificação.

Em nossa análise de conteúdo, unidades e subunidades de análise configuram aspectos avaliados. Indicadores, dimensões ou atributos são elementos concretos que permitem determinar a qualidade total ou parcial de cada aspecto (HERSCOVITZ, 2010, p. 132). Definições operacionais determinam a maneira como conceitos são medidos na amostra, proporcionando, para cada subunidade de análise, especificações precisa para: 1) indicadores - presença ou ausência de determinada característica (por exemplo, tabulação em sim e não); 2) dimensões proporção ou extensão de certas características (por exemplo, tabulação em sim, não e parcial) e 3) atributos - caráter de certas qualidades (por exemplo, tabulação em feminino e masculino). ${ }^{27}$ Dessa forma, subunidades de análise elaboradas para nossa pesquisa possuem indicadores, dimensões ou atributos fechados e sistematizados. ${ }^{28}$

Subunidades e suas respectivas respostas codificadas, aplicadas à análise dos 270 infovis que compõem nosso corpus de pesquisa, são agrupadas em duas seções: informações gerais e caracterização. A primeira objetiva reunir dados bibliográficos para identificação e localização da peça analisada (ID, ${ }^{29} \mathrm{URL}$, título do infovis, veículo de comunicação, editoria e ano de publicação). A segunda seção configura, propriamente, nosso protocolo de análise e apresenta unidades e subunidades investigativas agrupadas em três dimensões: input, interface e output.

O infovis, como dispositivo, pode ser compreendido como um sistema comunicacional com entrada (input) e saída (output) de informações e uma interface gráfico-comunicativa, espaço projetado pelos comunicadores no qual conteúdos são apresentados e usuários realizam ações interativas e participativas (Figura 13).

\footnotetext{
${ }^{27}$ Nesta pesquisa utilizamos, predominantemente, indicadores, mas é possível verificar dimensões e atributos.

${ }^{28}$ Com exceção de duas subunidades de análise da seção informações gerais - uniform resource locator (URL) e título - que não possuem respostas fechadas.

${ }^{29}$ Número de identificação com base em código catalográfico alfanumérico que identifica veículo e ano de publicação (por exemplo: NYT10_01 - infovis publicado pelo The New York Times em 2010, número 1).
} 


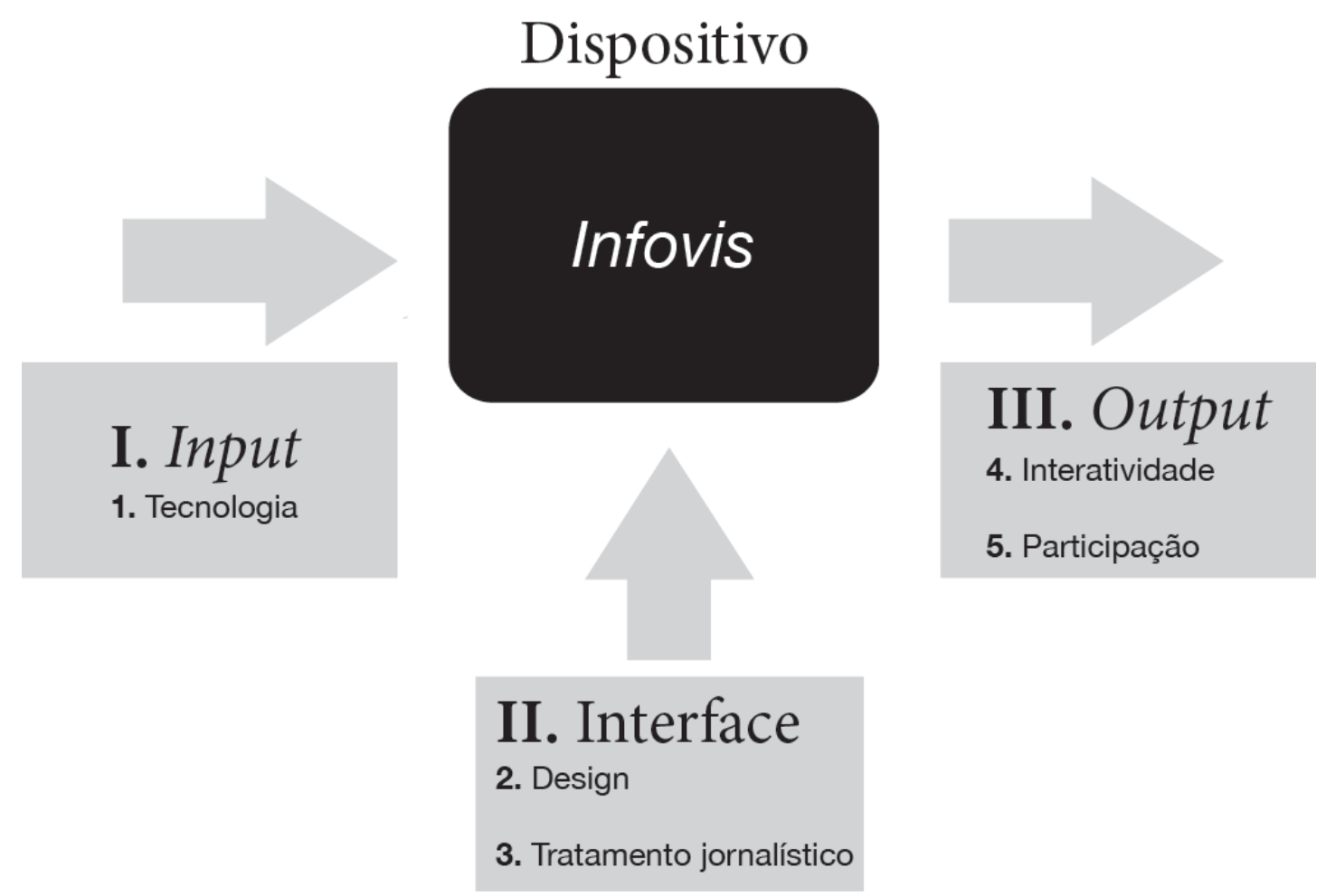

Figura 13 - Esquema representativo das dimensões e unidades de análise da seção caracterização. Fonte: elaboração própria.

Em nossa análise, input do dispositivo concentra-se na unidade tecnologia; interface do dispositivo concentra-se nas unidades design e tratamento jornalístico e objetiva avaliar a mediação dos produtores da informação na construção da mensagem jornalística; output do dispositivo concentra-se, por um lado, na interatividade, compreendida como recursos interativos para exploração do conteúdo, e, por outro, na participação, compreendida como ações participativas. Juntas interatividade e participação pretendem avaliar os caminhos do usuário na construção de seus percursos de consumo informativo. É importante destacar que interatividade e participação não podem ser desassociadas da interface do dispositivo, pois recursos interativos e ações participativas fazem parte dessa superfície comum a comunicadores e usuários. No entanto, ao situá-las na dimensão de análise output, privilegiamos as possibilidades de apropriação e ressignificação do conteúdo por parte dos usuários.

As cinco unidades - tecnologia, design, tratamento jornalístico, interatividade e participação) agrupam o total de nove subunidades de análise avaliadas em nossa pesquisa (Quadro 15). 
Quadro 15 - Distribuição das unidades e subunidades de análise

\begin{tabular}{|c|c|c|c|c|c|}
\hline $\begin{array}{l}2 \\
2 \\
2 \\
2 \\
2\end{array}$ & Input & \multicolumn{2}{|c|}{ Interface } & \multicolumn{2}{|c|}{ Output } \\
\hline 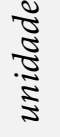 & Tecnologia & Design & $\begin{array}{l}\text { Tratamento } \\
\text { jornalístico }\end{array}$ & Interatividade & Participação \\
\hline \multirow{3}{*}{$\begin{array}{c}\frac{3}{3} \\
\frac{3}{3} \\
\frac{3}{3} \\
0\end{array}$} & $\begin{array}{l}\text { Ferramenta } \\
\text { de produção }\end{array}$ & $\begin{array}{c}\text { Modo de } \\
\text { organização } \\
\text { da informação }\end{array}$ & Temática & $\begin{array}{l}\text { Gradiente de } \\
\text { interatividade }\end{array}$ & Comentário \\
\hline & \multirow[t]{2}{*}{$\begin{array}{l}\text { Atualização } \\
\text { contínua }\end{array}$} & & \multirow[t]{2}{*}{$\begin{array}{l}\text { Gradiente de } \\
\text { mediação }\end{array}$} & & $\begin{array}{l}\text { Compartilha- } \\
\text { mento }\end{array}$ \\
\hline & & & & & $\begin{array}{l}\text { Conteúdo } \\
\text { gerado pelo } \\
\text { usuário }\end{array}$ \\
\hline
\end{tabular}

Fonte: elaboração própria.

Se, em um primeiro momento, apresentamos as dimensões de análise (Figura 13) como forças homogêneas na produção e no consumo informativo, destacamos no Quadro 15 maior enfoque nas dimensões interface e output, o que pode ser atribuído à ênfase de nossa pesquisa na investigação por gradientes de mediação jornalística e gradientes de interatividade contidos no dispositivo infovis.

Para entender como se articulam relações de mediação, por parte dos produtores, e de interatividade, por parte dos consumidores do conteúdo, e propor possíveis modalidades comunicativas na produção de infovis que emergem do resultado de forças entre essas duas dimensões, incorporamos, em nossa análise, a reflexão de Braga (2012a) acerca da existência de gradientes na comunicação. Para o autor, a noção de gradiente acompanha sua visão de que o processo comunicacional é tentativo, ou seja, entre a comunicação perfeita e ausência total de comunicação há “[...] uma dimensão contínua, com graus, níveis e direções variáveis de atingimento” (BRAGA, 2012a, p. 34).

Dessa forma, ao aplicar a noção de gradiente à análise do dispositivo infovis, pretendemos avaliar as unidades tratamento jornalístico e interatividade, de cada peça constituinte do corpus, em termos variáveis. A unidade tratamento jornalístico possui gradiente de mediação que varia de zero a dez segundo presença total, parcial ou ausência de sete parâmetros. A unidade interatividade possui gradiente de interatividade que varia 
de zero a dez segundo presença e ausência de dez parâmetros. Não pretendemos, por meio da criação de tais gradientes, medir em termos quantitativos a Comunicação. $\mathrm{O}$ interesse metodológico na criação de gradientes de análise é investigar diferentes modelos comunicacionais para produção de infovis, por meio do reconhecimento de estratégias de mediação jornalística e de interatividade com o conteúdo:

Não sugiro fragmentar a comunicação ou propor tratamento quantitativo. Trato de variações de valor - que é uma qualidade e não um tamanho. Parece-me razoável considerar que qualidades variam qualitativamente (BRAGA, 2012a, p. 35).

A seguir apresentamos o protocolo de análise. As subunidades da seção caracterização são agrupadas por dimensão e unidade e expõem suas qualidades analíticas com embasamento teórico no campo da Comunicação e do Design. A observação das respostas codificados oferece, isoladamente ou por meio do cruzamento com outras subunidades, apontamentos diretos para resultados e inferências apresentados e discutidos no próximo capítulo.

\subsubsection{Dimensão de input do dispositivo}

Objetivo: as subunidades analisadas nessa dimensão pretendem caracterizar aspectos tecnológicos envolvidos na produção do dispositivo infovis de forma categórica, ou seja, atribuir características seletivas sem conferir valor gradativo às respostas.

\subsubsection{Unidade tecnologia}

Subunidade ferramenta de produção: identifica se o infovis possui indicação de que houve uso utilização (tabulação de dados com base em sim e não) de ferramentas online e gratuitas - aplicativos de softwares baseados na web $\left(\mathrm{APIs}^{30}\right)$, como Google Fusion Tables e Tableau Public, entre outros) e outras ferramentas criativas - para

\footnotetext{
${ }^{30}$ Application Programming Interface (API) ou Interface de Programação de Aplicativos é um conjunto de instruções e padrões de programação para acesso às funcionalidades e serviços de softwares baseados na web, sem a necessidade de implementação do software em si. Em outras palavras, uma empresa de software - Google - cria seu API para que outros - jornalistas e designers de veículos comunicativos - possam desenvolver produtos infográficos - acionados por aplicativos desse serviço.
} 
produção de suas representações visuais e/ou implementação de recursos interativos para exploração do conteúdo.

A utilização dessas tecnologias gratuitas e disponibilizadas na rede compõe importante aspecto a ser analisado, pois inaugura novos produtos e atividades no jornalismo on-line, que podem significar não só a ampliação do uso de infovis em redações, mas também a compreensão de que esses produtos midiáticos vão além de artefatos tecnológicos, constituindo-se como práticas culturais (MANOVICH, 2001). O uso de APIs para criação de infovis, por exemplo, consolida a integração do formato infográfico com a base de dados e a circulação via internet. Para Manovich, bases de dados na web promovem novos modos de estruturar e produzir a experiência humana com o conteúdo, consolidando a ruptura com a linearidade e introduzindo a lógica do cruzamento informativo. Como consequência, o fato de ferramentas on-line e gratuitas ampliarem o uso da base de dados na infografia e

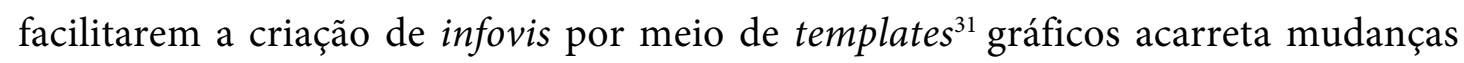
nos aspectos finais do infovis produzidos, assim como altera as dinâmicas dos profissionais envolvidos. A razão de essa subunidade de análise restringir-se à verificação de uso de base de dados de ferramentas on-line e gratuitas deve-se ao fato de que essas, quando utilizadas na produção de infovis, são acompanhadas da assinatura do software utilizado. Diferentemente, as bases de dados de software ou hardware internos ao computador não possuem marcas que nós, pesquisadores, podemos identificar sistematicamente.

Pretendemos cruzar essa subunidade com veículo de comunicação e editoria para verificar quais publicações e seções jornalísticas utilizam mais amplamente essa tecnologia e apresentar as ferramentas on-line e gratuitas mais frequentes em nosso corpus.

Subunidade atualização contínua: identifica se o infovis possui indicação ${ }^{32}$ de que o conteúdo é ou foi, em algum momento, atualizado continuamente (tabulação de dados com base em sim e não). Uma das características do jornalismo on-line, atualização constante ou contínua (PALACIOS, 2003), compõe fator importante que agrega novos

\footnotetext{
${ }^{31}$ Template é termo inglês, utilizado amplamente por profissionais do meio comunicativo, que designa documentos ou arquivos contendo unidades semântico-sintáticas básicas e preestabelecidas que servem de modelo inicial para um novo projeto.

${ }^{32}$ A identificação de atualização contínua é feita através do reconhecimento de expressões textuais de atualização como atualizado em, updated, acompanhe ao vivo, tempo real, live results, 100\% de votos apurados, 100\% reporting, etc.
} 
valores aos infovis que a utilizam. A possibilidade de os dados do infovis serem continuamente atualizados pode implicar novas tecnologias de produção infográfica - a presença da base de dados (RODRIGUES, 2009), por exemplo - e novos caminhos para infografia no jornalismo on-line - monitoramento e acompanhamento atualizado da informação. Pretendemos cruzar essa subunidade com veículo de comunicação e temática para saber quais publicações e assuntos priorizam essa tecnologia.

\subsubsection{Dimensão de interface do dispositivo}

Objetivo: pretende avaliar as unidades design e tratamento jornalístico que juntas compõem características mediadoras da interface do dispositivo infovis. Essa dimensão é composta de uma subunidade principal avaliada em termos gradativos, no caso o gradiente de mediação. O enfoque dessa dimensão está na construção de uma mensagem jornalística intencionada pelos produtores da informação - abordagem direcionada pelo autor (SEGEL; HEER, 2010).

\subsubsection{Unidade design}

Subunidade modo de organização da informação: indica o modo de organização dos dados apresentados e/ou manipulados por meio de recursos interativos. A tabulação dessa subunidade baseia-se na presença isolada ou combinada de tipos de relações entre os dados definidos por nós, no Capítulo 1 da dissertação (p. 45) a partir das contribuições de Bertin (2010), Card, Mackinlay e Shneiderman (1999), Engelhardt (2002), Richards (2000) e Wurman (1991): 1) quantitativo, quando relações entre dados podem ser mensuradas em termos de variação ou proporção; 2) grupal, quando dados são agrupados ou separados em dois ou mais conjuntos de elementos; 3) conectivo, quando dados estabelecem relação de ligação entre dois ou mais elementos; 4) temporal, quando dados revelam relações de ordem temporal e sequencial; 5) geográfico, ${ }^{33}$ quando dados são relacionados em uma superfície geográfica. Além de quantificar a frequência de cada modo de organização da informação visualizada no

\footnotetext{
${ }^{33}$ Reiteramos que dados geográficos representados isoladamente são evidências físicas. Dessa forma, para que um mapa possa ser considerado por nós infovis, ele precisa evidenciar relações de outras ordens (grupal, quantitativa, conectiva ou temporal).
} 
total da amostra, a fim de perceber se o conteúdo político enfatiza alguma das categorias, podemos relacioná-la com as subunidades ano de publicação e temática. Também buscamos reagrupar os modos de organização da informação, conforme a combinação dos domínios informativos e, dessa forma, investigar o hibridismo das representações gráficas. Para Engelhardt (2002, p. 137), representações gráficas de natureza primária apresentam somente um domínio informativo (quantitativo, grupal, conectivo, temporal ou geográfico), enquanto as de natureza híbrida oferecem ao menos dois domínios informativos combinados.

\subsubsection{Unidade tratamento jornalístico}

Subunidade temática: identifica o assunto predominante do infovis por meio de tabulação baseada nas três variações temáticas (tema 1, tema 2 e tema 3) estabelecidas por nós para a categoria de conteúdo (pag. 91, deste capítulo). Temática pode ser relacionada com duas subunidades do eixo caracterização - ano de publicação e editoria - apontando aspectos sobre o comportamento produtivo de infovis.

Subunidade gradiente da mediação: indica o gradiente de mediação do dispositivo infovis baseado na tabulação (sim, não e, em alguns casos, parcial) de parâmetros que caracterizam o tratamento jornalístico dos mediadores. Os parâmetros foram formulados a partir dos: 1) elementos estruturais do infográfico jornalístico, propostos por Leturia (1998) e Sojo (2002) - título, texto explicativo, fonte e crédito e 2) elementos de função comunicativa em visualizações, observados por Segel e Heer (2010) - artigo, nota e multimídia. A subunidade gradiente de mediação pretende atribuir ao infovis pontuação para cada parâmetro caracterizador de tratamento jornalístico contabilizado conforme especificações descritas no Quadro 16:

Quadro 16 - Recursos do gradiente de mediação

\begin{tabular}{|lll|}
\hline $\begin{array}{l}\text { Recurso de } \\
\text { tratamento } \\
\text { jornalístico }\end{array}$ & Definição operacional & Tabulação \\
\hline Título & $\begin{array}{l}\text { Texto direto, preferencialmente sintético, que } \\
\text { exprime o conteúdo do infovis (LETURIA, 1998) }\end{array}$ & Sim (1pt); \\
& & Não (0pt)
\end{tabular}




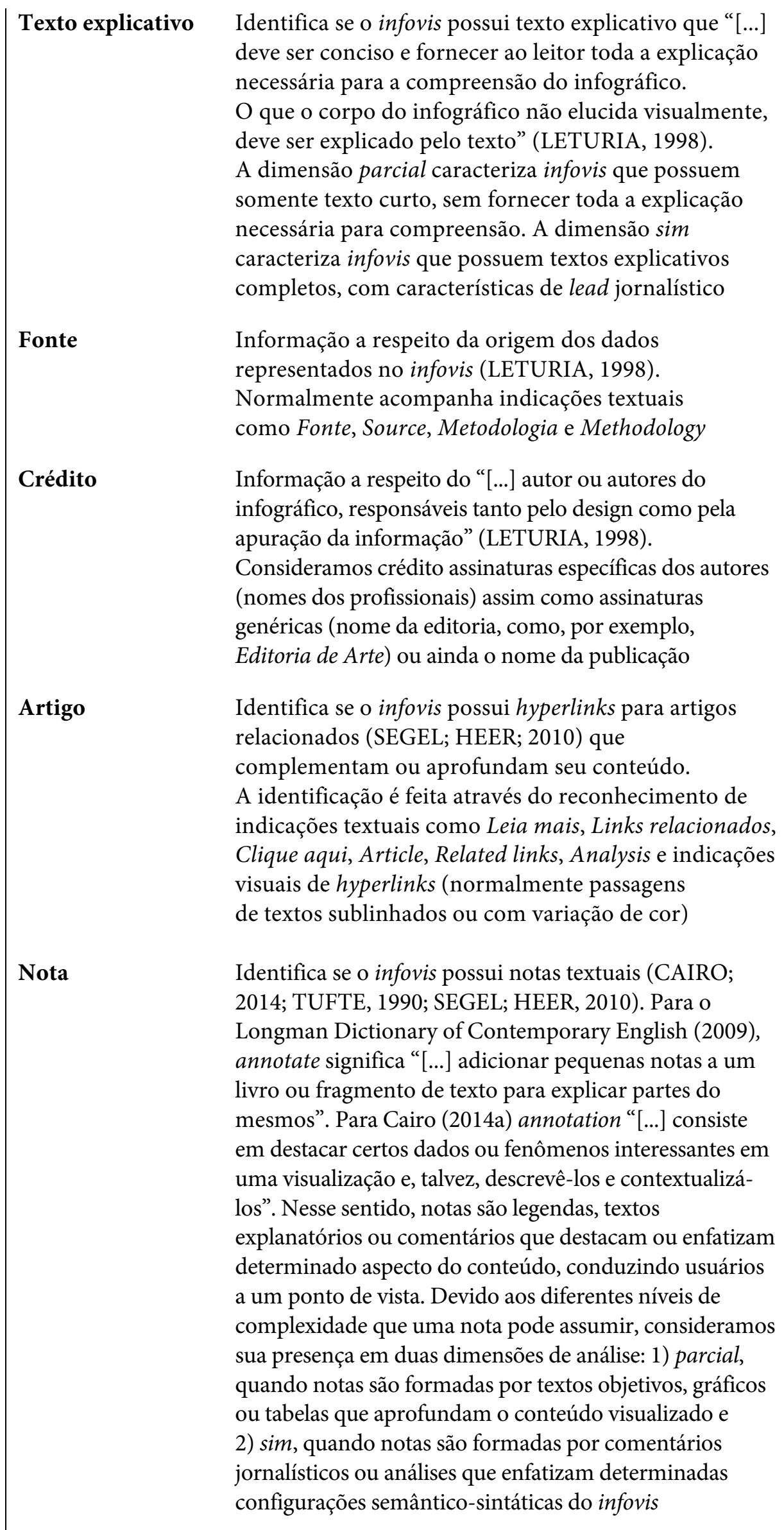

Sim (2pts); Parcial (1pt); Não (0pt)

$\operatorname{Sim}(1 \mathrm{pt})$ Não (0pt)

$\operatorname{Sim}(1 \mathrm{pt})$ Não (0pt)

$\operatorname{Sim}(1 \mathrm{pt})$ Não (0pt)

$\operatorname{Sim}(2 \mathrm{pts})$; Parcial (1pt); Não (0pt) nnotate significa [...] adicionar pequenas notas a um ro ou fragmento de texto para explicar partes do mos". Para Cairo (2014a) annotation "[...] consiste em textualizáos". Nesse sentido, notas são legendas, textos xplanatórios ou comentários que destacam ou enfatizam terminado aspecto do conteudo, con um ponto de vista. Devido aos diferentes níveis de complexidade que uma nota pode assumir, consideramos sua presença em duas dimensões de análise: 1) parcial, quando notas são formadas por textos objetivos, gráficos u tabelas que aprofundam o conteúdo visualizado e ) sim, quando notas são formadas por comentários configurações semântico-sintáticas do infovis 


$\begin{array}{|lll|}\text { Multimídia } & \text { Identifica se o infovis apresenta elementos multimídia } & \text { Sim (2pts); } \\ & \text { (CAIRO, 2008; PALACIOS, 2003), também chamados de } & \text { Parcial (1pt); } \\ & \text { multi-messaging (SEGEL; HEER, 2010) em sua página } & \text { Não (0pt) } \\ & \text { web, como foto, vídeo, áudio, animação, ilustração e } & \\ & \text { outras representações gráficas. Consideramos a presença } \\ & \text { de multimídia em duas dimensões de análise: 1) parcial, } & \\ & \text { somente uma mídia e 2) sim, duas ou mais mídias } & \\ \end{array}$

Fonte: elaboração própria.

O gradiente de mediação objetiva avaliar, para cada infovis, um índice de pontuação de zero a dez segundo critérios de tratamento jornalístico intencionado pelos produtores da informação (Quadro 16), que deverá ser contraposto ao índice de pontuação, em mesma escala, de gradiente de interatividade (Quadro 17, p. 114), da dimensão output. Juntos, os dois gradientes indicam resultados entre forças que um mesmo dispositivo infovis tem de explanar sequências de informação, segundo narrativas e discursos jornalístico-editoriais, e propiciar ao usuário a exploração do conteúdo a partir de percursos mais autônomos, sempre, no entanto, dentro de limites preestabelecidos pelos produtores da informação:

Os gêneros narrativos visuais, juntamente com a interatividade e a mensagem, devem equilibrar a narrativa guiada pelo autor com o percurso de descoberta narrativa traçado pelo leitor (SEGEL; HEER, 2010, p. 8).

Os autores apontam duas principais abordagens comunicacionais para o que denominam visualizações narrativas: abordagem direcionada pelo autor (authordriven) e abordagem direcionada pelo leitor (reader-driven). Em nossa análise, podemos associar a primeira às peças com maior índice de gradiente de mediação, e a segunda às peças com maior índice de gradiente de interatividade. Assim como os autores, não compreendemos as duas abordagens como espectro entre dois extremos dicotômicos e sem variações. Como apresentamos no capítulo de interpretação dos dados, peças evidenciam índices para gradiente de mediação e gradiente de interatividade de modo independente, o que nos possibilita estabelecer três diferentes modelos comunicacionais para infovis: 1) maior ênfase na abordagem direcionada pelo autor (logo, maior índice de gradiente de mediação); 2) maior ênfase na abordagem direcionada pelo usuário (logo, maior índice de gradiente de interatividade) e 3) equilibro entre as duas abordagens. 


\subsubsection{Dimensão de output do dispositivo}

Objetivo: pretende avaliar a subunidade interatividade, compreendida como recursos interativos para exploração do conteúdo, e a subunidade participação, compreendida como ações participativas, que, juntas, compõem aspectos interativos no consumo informativo e, algumas vezes, na produção do conteúdo, por parte dos usuários. Essa dimensão é composta de subunidades categóricas e de uma subunidade principal avaliada em termos gradativos, no caso o gradiente de interatividade. $\mathrm{O}$ enfoque dessa dimensão está nas estratégias pragmáticas, percursos narrativos que usuários realizam sobre o conteúdo visualizado - abordagem direcionada pelo usuário (SEGEL; HEER, 2010) - e nas ações participativas que exercem sobre ele, tornando-se propriamente interagentes do processo comunicacional.

\subsubsection{Unidade interatividade}

Subunidade gradiente de interatividade: indica o gradiente de interatividade do dispositivo infovis em uma escala de um a dez com base na identificação de dez parâmetros que correspondem aos recursos interativos para exploração do conteúdo identificados por nós. A subunidade gradiente de interatividade pretende atribuir ao infovis um ponto para cada recurso interativo quando presente (tabulação de dados com base em sim e não para cada parâmetro). Destacamos, no Quadro 17, os recursos interativos e suas definições operacionais:

Quadro 17 - Recursos do gradiente de interatividade

\begin{tabular}{|ll|}
\hline $\begin{array}{l}\text { Recurso interativo } \\
\text { para exploração } \\
\text { do conteúdo }\end{array}$ & $\begin{array}{l}\text { Definição } \\
\text { operacional }\end{array}$ \\
\hline $\begin{array}{l}\text { Avançar/retroceder } \\
\text { ou iniciar }\end{array}$ & $\begin{array}{l}\text { O recurso avançar/retroceder (CAIRO, 2008), também chamado } \\
\text { de botões de navegação (SEGEL; HEER, 2010), é normalmente } \\
\text { acompanhado pelo sinal gráfico de seta. Serve para navegar } \\
\text { linearmente pelo infovis ou iniciar (play) uma animação ou vídeo } \\
\text { nele contido }\end{array}$ \\
Roll over & $\begin{array}{l}\text { Para Tidwell (2006, apud CAIRO, 2008, p. 78), roll over consiste na } \\
\text { apresentação de unidades informativas secundárias quando usuários } \\
\text { passam o cursor do mouse sobre áreas ativas }\end{array}$ \\
\end{tabular}


Zoom

Filtragem

Relação

Busca

Extração

Customização

Outro painel de controle

Hipertextualidade
Zoom (TIDWELL, 2006, apud CAIRO, 2008, p. 78) constitui recurso para ampliação ou diminuição de determinada área que assim revela dados contidos em outras camadas informativas do infovis. Normalmente, zoom é acompanhado pelo sinal gráfico de $+\mathrm{e}-$

A filtragem (SHNEIDERMAN, 1996) está presente quando usuários podem desfazer a seleção de itens em um menu de opções, permitindo seu controle sobre elementos que deseja visualizar no infovis. Exemplo: no caso de um infovis que possui menu manipulável com estados brasileiros contendo itens - Todos, Acre, Alagoas, Amapá, etc. usuários podem escolher visualizar, na interface gráfica, dados de todos os estados ou, especificamente, apenas de um

Para Shneiderman (1996), relação constitui recurso interativo que possibilita relacionamento de itens de conjuntos de dados diferentes. Exemplo: tempo (anos) relacionado com estado (nome dos estados) em um infovis

O recurso interativo de busca (SEGEL; HEER, 2010) configura operação de preenchimento, em um campo livre, de uma palavra ou frase que será buscada na base de dados do infovis

Extração (SHNEIDERMAN, 1996) caracteriza-se por permitir que usuários façam download total ou parcial do conjunto de dados representado no infovis

Para Palacios (2003) a customização é a capacidade do usuário de personalizar o conteúdo. No caso do infovis, a customização compreende algumas especificidades destacadas por Rodrigues (2010, p. 9) como possibilidades de o usuário: 1) adaptar informações gráficas conforme suas preferências e objetivos e 2) manusear elementos interativos para gerar novas apresentações gráficas. Exemplos: 1) infovis que incorporam o API do Google Maps possuem o controle de visualização por mapa ou; 2) infovis que possuem a opção de esconder, mostrar e ampliar conteúdo visualizado (acompanham, normalmente, marcas textuais como expandir, contrair, tela cheia, expand, full screen, hide) e 3) infovis que permitem aos usuários interagir com sua interface escolhendo ou modificando sua forma sintática

Identifica se o infovis apresenta outros menus, barras ou listas manipuláveis, que não se encaixam no perfil dos recursos já descritos, mas permitem selecionar não linearmente, embora por meio de opções preestabelecidas, o conteúdo que será visualizado. Exemplo: barras deslizáveis com unidade temporal, botões que, quando clicados, revelam conteúdos adicionais

Identifica se o infovis apresenta hipertextualidade (PALACIOS, 2003), ou seja, interconexão de textos (compreendido em sentido amplo, como blocos informativos que podem ser, ademais de textos, fotos, vídeos e representações gráficas) mediante hyperlinks. Tecnicamente, a hipertextualidade pode ser identificada e analisada segundo diversos critérios. Nesta pesquisa, nosso objetivo é reconhecer a potencialidade que esse recurso interativo tem de aprofundar a compreensão de conjuntos de dados apresentados no corpo de infovis, e não analisar 
sua estrutura de navegação. Dessa forma, o recurso hipertextualidade identifica estritamente hyperlinks no corpo visual-interativo do infovis que direcionam o usuário para outras páginas web internas (pertencentes à publicação) ou externas.

Fonte: elaboração própria.

Além do objetivo de cruzar o gradiente de interatividade com o gradiente de mediação, a fim de verificar possíveis modelos comunicacionais, intencionamos verificar a frequência de um recurso interativo em particular. Extração (SHNEIDERMAN, 1996) caracteriza-se por permitir aos usuários efetuar download total ou parcial de conjuntos de dados representado em infovis. Do ponto de vista comunicacional, é relevante destacar as possibilidades de ressignificação que esse recurso interativo promove ao possibilitar aos usuários acesso aos dados brutos.

\subsubsection{Unidade participação}

A unidade participação pretende suprir lacunas que a análise focada apenas em recursos tecnológicos de interatividade não consegue realizar. Para tal, é constituída de três parâmetros qualitativos para compreensão do output interativo do infovis sob a perspectiva das ações participativas, interações sociais e novos usos comunicacionais que usuários podem exercer sobre o conteúdo proporcionado pelo suporte de circulação on-line. Em nossa análise, ações participativas correspondem à atividades de nível de interatividade conversacional e de registro (SALAVERRÍA, 2005, p. 34).

Subunidade comentário: identifica, por meio de tabulação de dados baseada em sim e não, se o infovis possui, em sua página web, espaços abertos indicados para comentários de usuários. Comentar corresponde à ação interativa de qualidade conversacional (SALAVERRÍA, 2005), que permite aos usuários não só consumir informações em um produto midiático, mas também, a partir dele, emitir suas opiniões, corrigir dados, fazer sugestões, criticar e gerar discussões com outros leitores, constituindo, dessa forma, um processo de inteligência coletiva (LÉVY, 1999). Comentários são realizados, na maioria das vezes, em tempo real, mas sob supervisão de jornalistas que podem filtrar e/ou 
selecionar comentários dos usuários por meio de ações de gatekeeping. ${ }^{34}$ Observamos a incidência dessa subunidade no total da amostra e por veículo de comunicação.

Subunidade compartilhamento: identifica, por meio de tabulação de dados com base em sim e não, se o infovis pode ser compartilhado em ao menos um dos seguintes modos: enviado por e-mail, compartilhado nas mídias sociais (Facebook, Twitter, Google Plus, Linkedin, MySpace, Orkut, etc.) ou recomendado (opção exclusiva para Facebook). O compartilhamento repercute na etapa de circulação e distribuição dos produtos midiáticos (JENKINS, 2011, p. 29) e depende diretamente da participação ativa do usuário, que não chega a produzir novos conteúdos, mas torna-se multiplicador da mensagem por meio da consolidação de tecnologias de distribuição da informação que descentralizam a emissão. Observamos a incidência dessa subunidade no total da amostra e por veículo de comunicação.

Subunidade conteúdo gerado pelo usuário: identifica, por meio de tabulação de dados com base em sim e não, se o infovis possibilita aos usuários registrar conteúdos ${ }^{35}$ sobre sua interface visual-interativa de modo permanente. Conteúdos gerados por usuários podem ser evidenciados, na produção de infovis, em dois casos distintos: 1) no uso de novas fontes de produção de conteúdo jornalístico e 2) na passagem dos níveis de interatividade de transmissão e consulta (SALAVERRÍA, 2005), caracterizados pelos recursos interativos para exploração do conteúdo, para níveis de interatividade conversacional e de registro (SALAVERRÍA, 2005), caracterizados por ações participativas (PRIMO; TRÄSEL 2006) realizadas por interagentes. O primeiro caso refere-se ao uso de dados coletados de mídias sociais para produzir infovis. ${ }^{36}$ Como alerta artigo publicado no sítio Jornalismo nas Américas, mídias sociais (especialmente o twitter) configuram não somente

\footnotetext{
${ }^{34}$ Gatekeeping, é conceito utilizado no Jornalismo para explicar "[...] o desenvolvimento do fluxo de notícias dentro dos canais organizacionais dos aparatos de informação e, sobretudo, para definir os pontos que funcionam, como "cancelas", que determinam se a informação passa ou é rejeitada" (WOLF, 2010, p. 184).

${ }^{35} \mathrm{Em}$ termos gerais, conteúdo gerado pelo usuário (user-generated content) refere-se "[...] a qualquer material criado e disponibilizado na Internet por um não profissional de mídia” (IAB, 2008, p.1). No entanto, atentamos para o fato de que, no caso de infográficos em portais jornalísticos, os usuários são apenas parcialmente geradores dos conteúdos disponibilizados.

${ }^{36} \mathrm{O}$ conceito de conteúdo gerado pelo usuário (VICKERY; WUNSCH-VINCENT, 2007) inclui diversas mídias, como texto, foto, imagem, música, áudio, vídeo e filme, que podem ser tanto coletadas de mídias sociais como enviadas diretamente por usuários à publicação.
} 
importantes fontes para obtenção de notícias, mas, sobretudo, prática “[...] cada vez mais integrada ao modelo de negócio das organizações de notícias, especialmente em âmbito local, em que a contração da indústria e a curadoria de conteúdo fazem a reportagem tradicional perder espaço” (DYER, 2013). Entretanto, em nossa análise nos concentramos no segundo caso, em que o conteúdo gerado pelo usuário se refere não ao processo prévio de apuração dos dados, mas ao momento de registro e armazenamento de escolhas e opções realizadas por usuários no infovis, uma vez que ele é colocado em circulação. Para Fausto Neto (2010, p. 55) “[...] a circulação institui novas formas de interações entre produtores e receptores de mensagens, complexificando seus papéis, ao organizá-los segundo novas dinâmicas de interface”. Dessa forma, usuários passam a ter a possibilidade de se tornar, além de consumidores informativos, produtores mais ativos na constituição do conteúdo texto-visual apresentado no corpo do infovis, o que nos aproxima do conceito de produsage, ou seja, “[...] construção colaborativa e contínua e extensão de conteúdo existente na busca por incremento posterior" (BRUNS, 2008, p. 21). Infovis que evidenciam essa qualidade enquadram-se no nível de interatividade de registro (SALAVERRÍA, 2005, p. 34), que ocorre quando meios são capazes de registrar informações geradas por usuários e adaptar seu formato e/ou conteúdo, conforme dados ou preferências inseridos. É importante destacar que o contexto produtivo de infovis em sítios jornalísticos limita possíveis ações participativas do usuário frente ao produto midiático. A atividade jornalística pertence, tradicionalmente, a um campo da Comunicação mais conservador, e, dessa forma, a função mediadora de jornalistas e designers é percebida de modo mais enfático por meio de decisões editoriais e escolhas de design e de interface que interferem tanto nos percursos interativos oferecidos aos usuários quanto nas possibilidades criativas que eles podem realizar.

Pretendemos quantificar a frequência das respostas dessa subunidade na amostra e cruzá-la com veículo de comunicação. 


\subsection{CODIFICAÇÃO E REDUÇÃO}

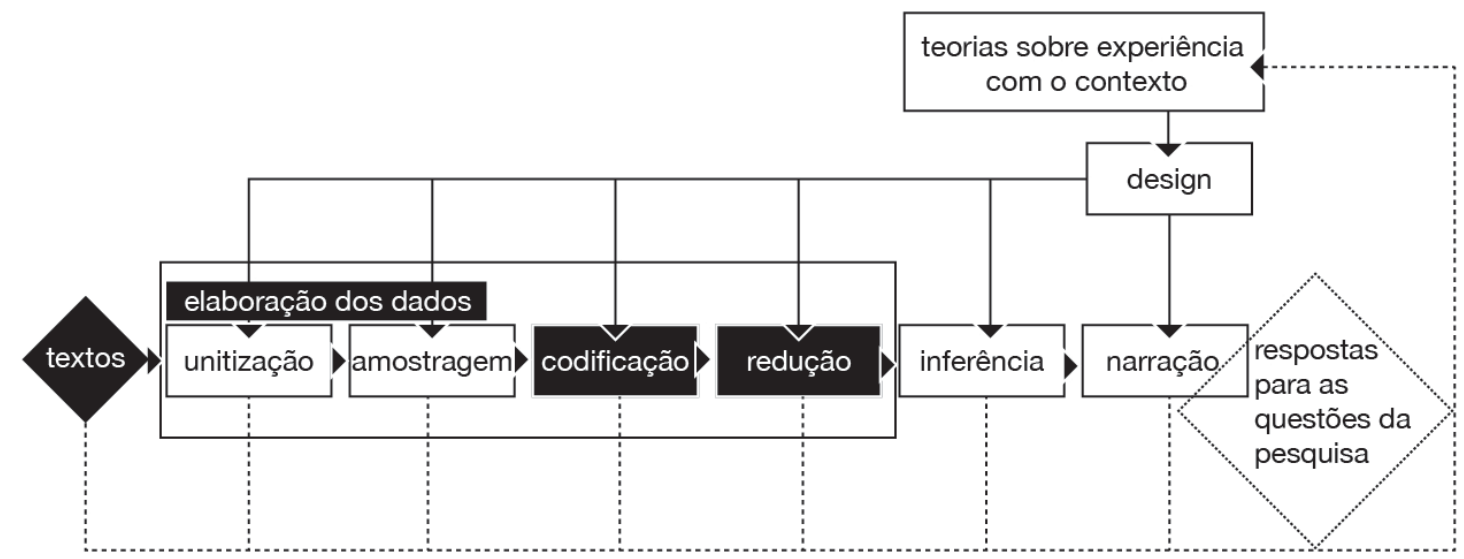

Figura 14 - Etapas de codificação e redução. Fonte: Krippendorff, 2004, p. 86.

Retomando as etapas da análise de conteúdo (Figura 14), a codificação consiste na terceira subetapa de elaboração dos dados, e compreende preenchimento do formulário de análise segundo medidas de unitização e amostragem. Reiteramos que o formulário preenchido pode ser conferido no Anexo 1 (versão digital).

Já a redução, última subetapa de elaboração dos dados, compreende depuração da análise a partir de pré-testes, durante fase de codificação, que podem representar modificações nas subetapas de unitizição e amostragem. Um caso que exemplifica o processo de redução nessa pesquisa é a eliminação de peças do veículo de comunicação $O$ Globo de nossa análise, no momento em que percebemos dificuldades em averiguar, na maioria das vezes, ano de publicação dos infovis. Dessa forma, precisamos retornar à subetapa amostragem e modificá-la. Outros casos que consistiram em depuração da análise foram eliminações de subunidades de análise que se mostraram inconsistentes durante fase de codificação e, até mesmo, a inclusão de novas que não haviam sido previstas no momento do design da análise de conteúdo, como, por exemplo, a subunidade participação. Quanto à subunidade modo de organização da informação, vale ressaltar que ela foi projetada, inicialmente, para analisar a estrutura sintática de infovis com base na classificação de tipos de representação gráfica desenvolvida por Engelhardt (2002, p. 137-145). No entanto, a dificuldade de aplicar a classificação do autor em infovis ${ }^{37}$ e a falta de resultados e

\footnotetext{
${ }^{37}$ Engelhardt (2002) desenvolve notória classificação para tipos de representação gráfica levando em conta sua construção no suporte plano e estático. No entanto, a plataforma digital e on-line possibilita maior variedade de
} 
inferências relevantes a partir da interpretação dos dados codificados nos levaram à necessidade de rever sua presença em nossa análise. Em vez de eliminá-la, reduzimos e modificamos as categorias para modos de organização da informação - quantitativo, grupal, conectivo, geográfico ou temporal (Capítulo 1, p 44)-, que podem ser evidenciados, em um mesmo infovis, isoladamente ou combinados.

A análise de conteúdo constitui técnica de pesquisa para produzir resultados e validar inferências a partir da leitura das respostas obtidas no formulário de análise. Portanto, não se trata de metodologia com fim em si mesmo, mas sim de meio para detectar tendências, padrões e diferenças nos diversos segmentos em que a análise pode ser aplicada. No campo da comunicação jornalística, a análise de conteúdo serve para:

[...] descrever e classificar produtos, gêneros e formatos jornalísticos, para avaliar características na produção de indivíduos, grupos e organizações, para identificar elementos típicos, exemplos representativos e discrepâncias e para comparar o conteúdo jornalístico de diferentes mídias e diferentes culturas (HERSCOVITZ, 2010, p. 123).

Em nossa pesquisa, a análise de conteúdo é direcionada para refletir e responder a questões a respeito das dimensões do dispositivo infovis com base em perguntas sobre tecnologia de produção, interatividade contrabalanceada com a mediação e, finalmente, ações participativas que reconfiguram produção e consumo do conteúdo em produtos midiáticos no jornalismo on-line. Em última instância, o desenvolvimento de infovis cujo input pode ser mais produtível, atualizável e custeável, e cujo output pode ser mais manipulável e participativo, por parte do usuário, reincide em questões que reconfiguram as atividades e os produtos jornalísticos em diversos aspectos no contexto digital, on-line e sobrecarregado de dados, a saber: 1) mudanças no processo de apuração, produção e circulação do conteúdo informativo, assim como transformações nas atividades de jornalistas e designers envolvidos; 2) emergência de narrativas e produtos mais interativos e visuais e 3) maior abertura do dispositivo midiático e empoderamento do usuário frente a seus percursos de leitura e fruição do conhecimento.

A seguir apresentamos nossa leitura e interpretação dos dados codificados no formulário de análise.

organizações informativas por meio de estruturas interativas em camadas de navegação, que extrapolam, em muitos casos, os limites das classificações desse autor. 


\section{Interpretação dos dados}

A partir do formulário preenchido com dados da análise de conteúdo (Anexo 1, versão digital) ${ }^{1}$, foi realizada leitura sistemática, por meio de operações de média absoluta e percentual da ocorrência das respostas de cada subunidade de análise isoladamente e por meio de cruzamentos entre respostas de determinadas subunidades a fim de buscarem-se relações entre elas. Para evidenciar tais relações e facilitar interpretações e reflexões a partir dos resultados, compilamos e apresentamos, em forma de tabela, as respostas em valor absoluto (número de peças) para cada subunidade de análise. Reiteramos que, em nível específico, a proposta da análise de conteúdo por meio da leitura dos dados codificados é inferir questões percebidas na produção de infovis dos quatro sítios jornalísticos destacados sem, no entanto, utilizar inferências como medidas estatísticas comprobatórias e genéricas, dado que o universo da amostra possui um recorte semântico específico.

\subsection{DIMENSÃO INPUT}

Tabela 2 - Resultados da dimensão input de análise

\begin{tabular}{|c|c|c|c|c|c|c|c|}
\hline \multirow[t]{2}{*}{ Unidade } & \multirow[t]{2}{*}{ Subunidade } & \multirow[t]{2}{*}{ Indicadores } & \multicolumn{3}{|c|}{ Veículo comunicativo $^{2}$} & \multirow[b]{2}{*}{ ESP } & \multirow[b]{2}{*}{ Total } \\
\hline & & & NYT & TGU & FSP & & \\
\hline \multirow{4}{*}{ 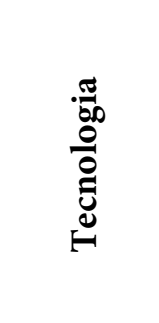 } & \multirow{2}{*}{$\begin{array}{l}\text { Ferramenta } \\
\text { de produção }\end{array}$} & Sim & 1 & 16 & 11 & 38 & 66 \\
\hline & & Não & 80 & 49 & 39 & 36 & 204 \\
\hline & \multirow{2}{*}{$\begin{array}{l}\text { Atualização } \\
\text { contínua }\end{array}$} & Sim & 33 & 12 & 9 & 11 & 65 \\
\hline & & Não & 48 & 53 & 41 & 63 & 205 \\
\hline
\end{tabular}

Fonte: elaboração própria.

\footnotetext{
${ }^{1}$ Disponível em CD e na web através do endereço <http://goo.gl/bfQac0>.

${ }^{2}$ As siglas referentes aos veículos comunicativos The New York Times (NYT), The Guardian (TGU), Folha de S. Paulo (FSP) e O Estado de S. Paulo (ESP).
} 


\subsubsection{Ferramenta de produção}

A Tabela 2 apresenta o número de infovis que indicam utilização (66 peças ou $24 \%)^{3}$ e não utilização (204 peças ou 76\%) de ferramentas on-line e gratuitas aplicativos de softwares baseados na web (APIs $\left.{ }^{4}\right)$ e outras ferramentas criativas - para produção de suas representações visuais e/ou implementação de recursos interativos de exploração do conteúdo.

Do total dos 66 infovis que indicam uso de alguma ferramenta de produção on-line e gratuita, 38 pecas ( $14 \%$ da amostra total) pertencem a O Estado de S. Paulo; 16 (6\% da amostra total) são do The Guardian; 11 (4\% da amostra total) pertencem à Folha de S. Paulo; e 1 (menos de 1\% da amostra total) é do The New York Times. Por sua vez, os 38 infovis de O Estado de S. Paulo correspondem, aproximadamente, a 51\% dos infovis da amostra pertencentes a esse veículo de comunicação. O domínio de $O$ Estado de S. Paulo na análise da subunidade ferramenta de produção reflete o fato de que a publicação vem destacando, sobretudo nos últimos dois anos, junto à consolidação da seção Estadão Dados, ${ }^{5}$ o uso de ferramentas on-line e gratuitas na produção de seus infovis que, por sua vez, buscam interpretar e comunicar dados divulgados e disponibilizados diariamente, a maioria deles de interesse político e econômico. Podemos associar essa prática protagonizada em nossa amostra por $O$ Estado de S. Paulo, mas também notável em peças do The Guardian e da Folha de S. Paulo, à necessidade do Jornalismo de lidar com certos desafios atuais. O cenário que evidenciamos e no qual o dispositivo infovis se destaca junto ao uso de ferramentas de produção on-line e gratuitas, como os APIs, é aquele em que o Jornalismo busca: 1) processar abundantes conjuntos de dados; 2) apresentar o conteúdo de forma compreensível e significante e 3) adaptar o exercício profissional da comunicação a um modelo rentável, veloz e interdisciplinar. Rogers (2011, apud SAAD CORRÊA; BERTOCCHI, 2012, p. 140), editor da seção Datablog, ${ }^{6}$ do The Guardian, aponta que:

\footnotetext{
${ }^{3}$ Os valores percentuais apresentados neste capítulo são valores aproximados.

${ }^{4}$ Reiteramos que Application Programming Interface (API) ou Interface de Programação de Aplicativos é um conjunto de instruções e padrões de programação para acesso às funcionalidades e serviços de softwares baseados na web, sem a necessidade de implementação do software em si. Em outras palavras, uma empresa de software Google - cria seu API para que outros - jornalistas e designers de veículos comunicativos - possam desenvolver produtos - infográficos - acionados por aplicativos desse serviço.

${ }^{5}$ A seção está disponível em: <http://blog.estadaodados.com $>$.

${ }^{6}$ A seção está disponível em: <http://www.theguardian.com/news/datablog>.
} 
[...] hoje existe uma tal quantidade de dados disponíveis no mundo que procuramos oferecer em cada notícia os fatos principais - e encontrar a informação correta pode se transformar numa atividade jornalística tão intensa quanto buscar os melhores entrevistados para uma matéria (...) Qualquer um pode fazer isso... Especialmente com ferramentas gratuitas como o Google Fusion Tables, Many Eyes, Google Charts ou Timetric - e você pode acessar postagens dos leitores no seu grupo do Flickr (...) Mas a tarefa mais importante é pensar sobre os dados obtidos mais como jornalista do que como um analista. O que é interessante sobre tais dados? $O$ que é novo? $O$ que aconteceria se eu mesclasse com novos dados? Responder tais perguntas é da maior importância. Funciona se pensarmos numa combinação disso tudo (grifo nosso).

Dessa forma, podemos inferir que o emprego de ferramentas on-line e gratuitas torna a produção e difusão do infovis atividades mais acessíveis e velozes, sem adição de custos para redações e, em alguns casos, sem necessidade de especialistas em design e infografia no comando de tais processos. Para Cairo (2012), ainda é preferencial que designers atuem na criação de produtos do jornalismo visual, mas é impossível negar que, hoje em dia, tal prática está ao alcance de qualquer um suficientemente interessado em aprender operações básicas do "[...] Tableau Public, Many Eyes [...] Visual.ly, Infogr.am, Datawrapper, Google Charts, Google Fusion Tables, e outras muitas outras ferramentas open source, gratuitas e disponíveis". Dessa forma, destacamos que o jornalista atual, provido de ferramentas de produção como as citadas e de conhecimentos em Design, pode tornar-se criador de seus próprios infovis. Durante a etapa de codificação, em nossa análise, identificamos o uso de 11 aplicativos de softwares baseados na web (APIs) ou ferramentas criativas. ${ }^{7}$ Para comentar, porém, privilegiamos aqueles que foram mais incidentes no corpus ou que foram referenciados na bibliografia consultada.

Voter apathy 1964-2010: What's changed? (TGU_1301) ${ }^{8}$ (Figura 15), publicado pelo The Guardian em 27 de dezembro de 2013, trata-se de um infovis que visualiza resultados de uma pesquisa sobre hábitos de voto no Reino Unido e busca respostas que justifiquem motivos pelos quais os britânicos não têm comparecido às urnas ultimamente. A peça, que possui dois modos de organização da informação presentes

\footnotetext{
${ }^{7}$ Google Fusion Tables, Google Docs, Google Charts, Tableau Public, Datawrapper, Timeline JS, MapBox, CartoDB, Plotly, Infogr.am e Highcharts.

${ }^{8}$ Neste capítulo, citamos o código catalográfico das peças para remeter ao formulário de análise preenchido (Anexo 1, versão digital).
} 
em sua primeira cena da navegação (quantitativo e temporal), corresponde a um dos três infovis, ${ }^{9}$ do total da amostra, que utilizam a ferramenta Tableau Public ${ }^{10}$ para suas produções. Embora Tableau Public tenha baixa incidência de uso em nossa amostra, é destacada, por autores, especialistas e pesquisadores em infografia - Cairo (2014) e Kosara (2010) -, como potencial ferramenta de produção para representações gráficas. Tableau Public é a versão gratuita do Tableau Software, ferramenta paga com mais recursos disponíveis para criação de visualizações interativas. Embora tenha algumas limitações, Kosara (2014) aponta que a versão gratuita pode ser baixada para o desktop do computador, permite importar grandes quantidades de dados, possibilita uso de filtros interativos e conjuga múltiplos painéis informativos.

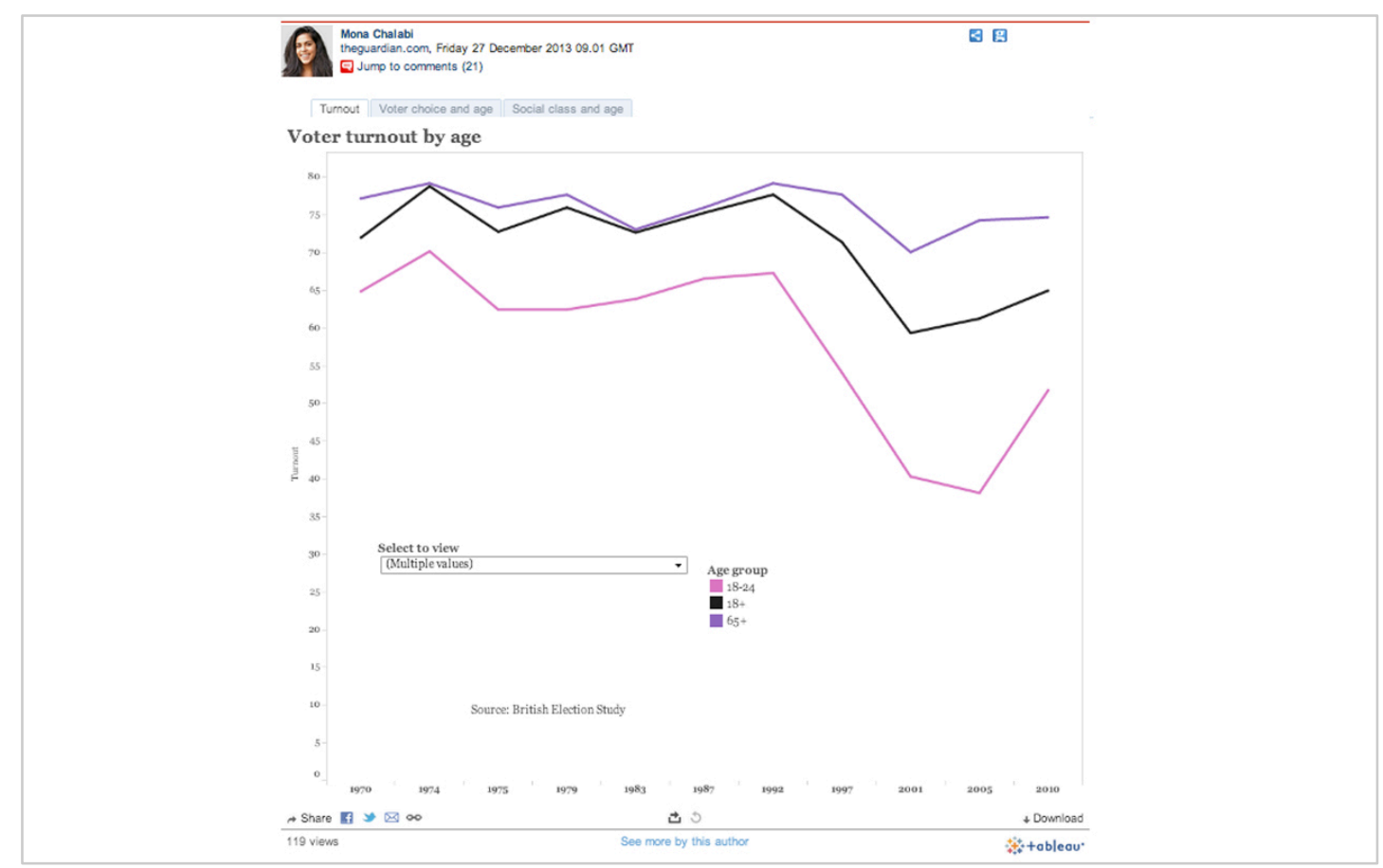

Figura 15 - Voter apathy 1964-2010: What's changed?- Uso do software Tableau Public. Fonte: The Guardian, $2013^{11}$.

Local elections 2013: results mapped (TGU_1310) (Figura 16), publicado pelo The Guardian em 27 de dezembro de 2013, trata-se de um infovis que apresenta os resultados dos 35 conselhos da Inglaterra e do País de Gales nas eleições locais de 2009 e 2013 agrupados por preferência partidária e distribuídos em um plano geográfico. A peça

\footnotetext{
${ }^{9}$ As outras peças são TGU_1304 e TGU_1206.

${ }^{10}$ Disponível em <http://www.tableausoftware.com/public/>

${ }^{11}$ Disponível em: <http://www.theguardian.com/news/datablog/interactive/2013/dec/27/voter-apathy-1964-2010change-voting-behaviour>. Acesso em fev. 2014.
} 
corresponde a um dos 20 infovis, ${ }^{12}$ do total da amostra, que utilizam o aplicativo baseado na web (API) Google Fusion Tables ${ }^{13}$ para sua produção. Trata-se da ferramenta on-line e gratuita com maior incidência em nosso corpus dentre as peças que indicaram resposta sim na subunidade ferramenta de produção. Google Fusion Tables é mencionada como a principal ferramenta on-line e gratuita para criação de representações geográficas e, diferentemente do Tableau Public, não se caracteriza por ser um software. Pelo contrário, o Google Fusion Tables constitui-se como ferramenta baseada na web, utiliza o API do Google Maps e possibilita a integração com outras ferramentas do Google (Google Docs e Google Spreadsheets) para codificar dados em mapas.

Rogers (2014) ressalta que Google Fusion Tables produz mapas de forma rápida e detalhada, além de suportar um grande volume de dados. Trata-se de uma ferramenta flexível e dinâmica em que, segundo o autor, “[...] você não precisa ser um programador para criar um mapa" (ROGERS, 2014).

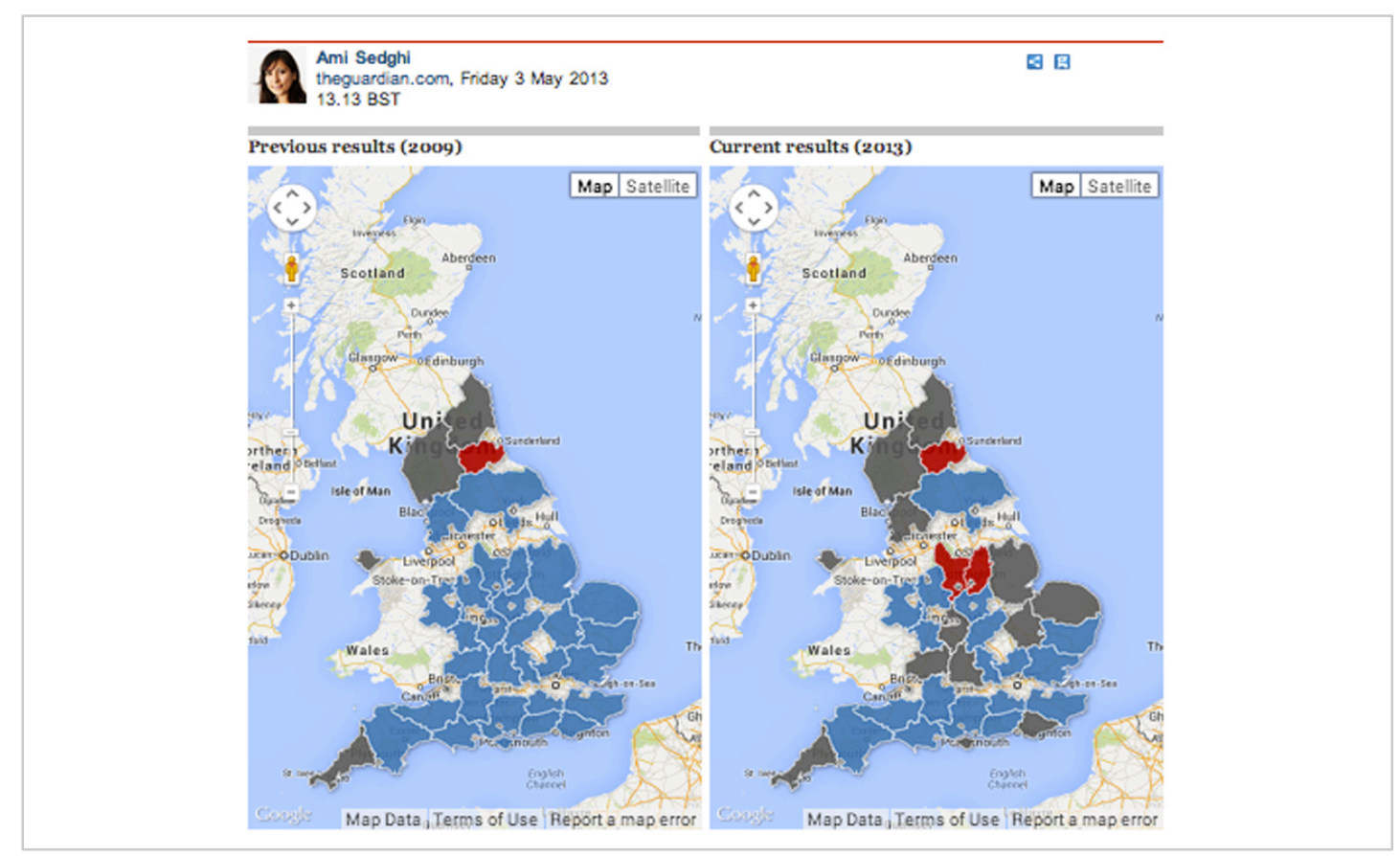

Figura 16 - Local elections 2013: results mapped - Uso do Google Fusion Tables. Fonte: The Guardian, 2013. ${ }^{14}$

\footnotetext{
${ }^{12}$ As outras peças são NYT_1211, TGU_1302, TGU_1312, TGU_1314, TGU_1316, TGU_1201, TGU_1207, TGU_1209, TGU_1210, TGU_1214, FSP_1307, FSP_1213, FSP_1214, FSP_1101, ESP_1201, ESP_1210, ESP_1002, ESP_1004, ESP_1014.

${ }^{13}$ Disponível em: <http://www.google.com/drive/apps.html\#fusiontables $>$.

${ }_{14}$ Disponível em: <http://www.theguardian.com/news/datablog/interactive/2013/may/03/local-election-resultsmapped $>$. Acesso em fev. 2014.
} 
Veja quem é mais popular: Dilma ou o governador (ESP_1301) (Figura 17), publicado por O Estado de S. Paulo em 13 de dezembro de 2013, trata-se de um infovis que apresenta o índice de popularidade (evidência quantitativa) da presidente e dos governadores do Brasil por estado. A peça corresponde a um dos três infovis ${ }^{15}$ do total da amostra que utilizam o aplicativo baseado na web (API) Plotly ${ }^{16}$ para sua produção. O aplicativo Plotly define-se, em sua página web, como “[...] uma ferramenta colaborativa para análise de dados e visualização" e, embora tenha baixa incidência em nossa amostra, é destacada por Cairo (2014b) como uma promissora e nova ferramenta para o desenvolvimento de visualizações interativas.

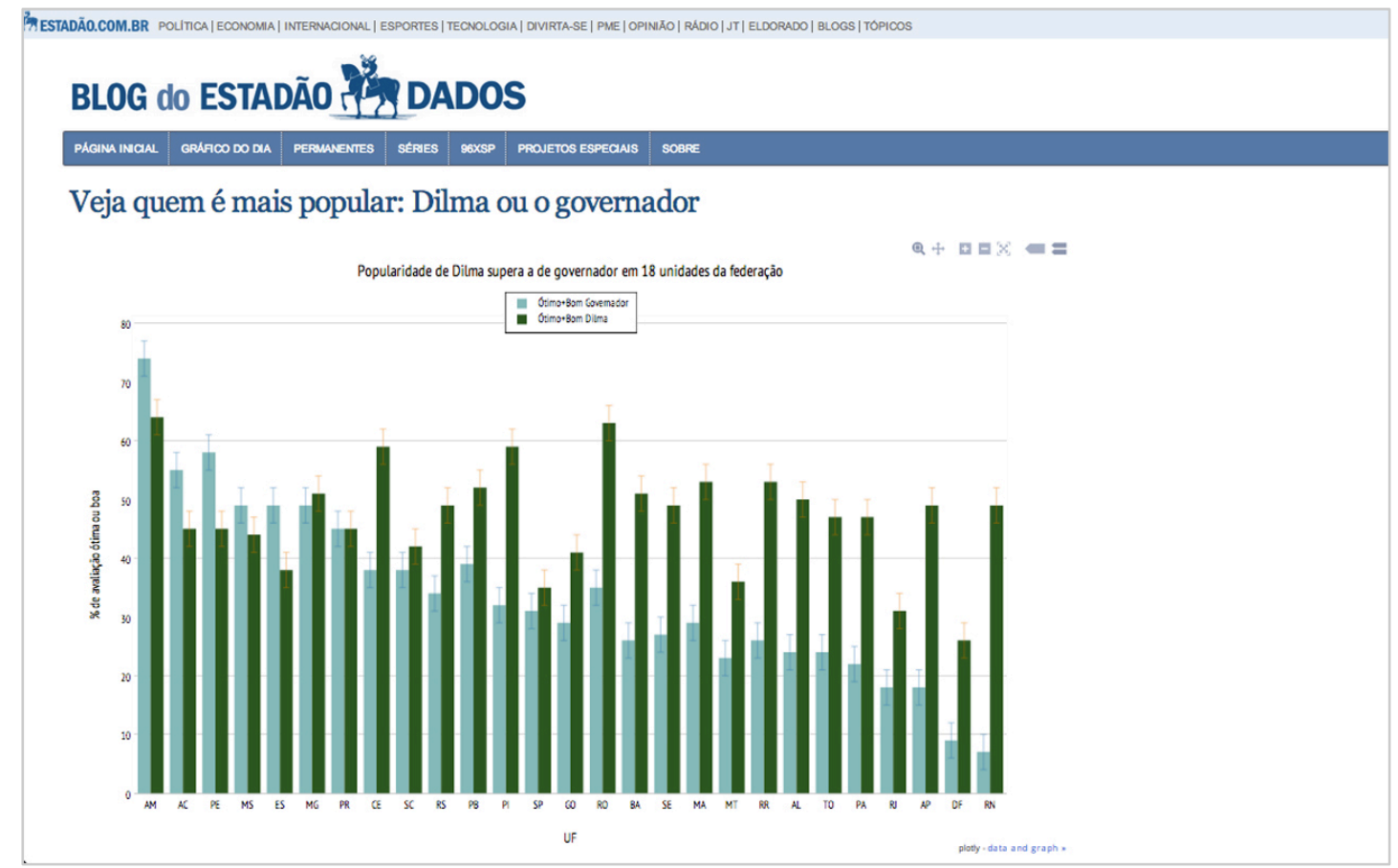

Figura 17 - Veja quem é mais popular: Dilma ou o governador - Uso do Plotly. Fonte: O Estado de S. Paulo, 2013. ${ }^{17}$

A evolução do custo dos partidos para os cofres públicos (ESP_1331) (Figura 18), publicado por O Estado de S. Paulo em 4 de março de 2013, trata-se de um infovis que apresenta os gastos (evidência quantitativa) dos partidos políticos brasileiros para os cofres públicos. A peça é um dos 17 infovis ${ }^{18}$ da amostra total, todos do veículo O Estado

\footnotetext{
${ }^{15}$ As outras peças são ESP_1306 e ESP_1307.

${ }^{16}$ Disponível em: $<$ https://plot.ly/ $>$.

${ }^{17}$ Disponível em: <http://blog.estadaodados.com/veja-quem-e-mais-popular-dilma-ou-o-governador>. Acesso em jan. 2014.

${ }^{18}$ As outras peças são ESP_1302, ESP_1304, ESP_1312, ESP_1313, ESP_1315, ESP_1316, ESP_1318, ESP_1323, ESP_1324, ESP_1325, ESP_1326, ESP_1327, ESP_1328, ESP_1329, ESP_1330, ESP_1331, ESP_1332.
} 
de S. Paulo, que utilizam a ferramenta de produção Infogr.am ${ }^{19}$ em suas criações. A alta incidência do Infogr.am como ferramenta de produção em nossa amostra deve-se ao fato do forte apelo visual em termos de cores e formas gráficas que ela oferece para “[...] criar infográficos em poucos cliques, publicá-los em artigos, postá-los em blogs e compartilhá-los com amigos" (INFOGR.AM, s.d.), nas palavras de seus criadores. No entanto, devemos atentar para o fato de que apelo visual e facilidade técnica podem, de fato, ampliar a produção de infovis em termos quantitativos, mas, nem sempre, em termos qualitativos. Tufte observa que efeitos ópticos, texturas redundantes e outras soluções de design sem função proliferaram com o uso de computadores e softwares (TUFTE, 1983, p. 120), produzindo aquilo que o autor chama de chartjunk (lixo gráfico, em tradução livre), o triunfo da decoração gráfica e da técnica em detrimento do conteúdo e da clareza informativa.

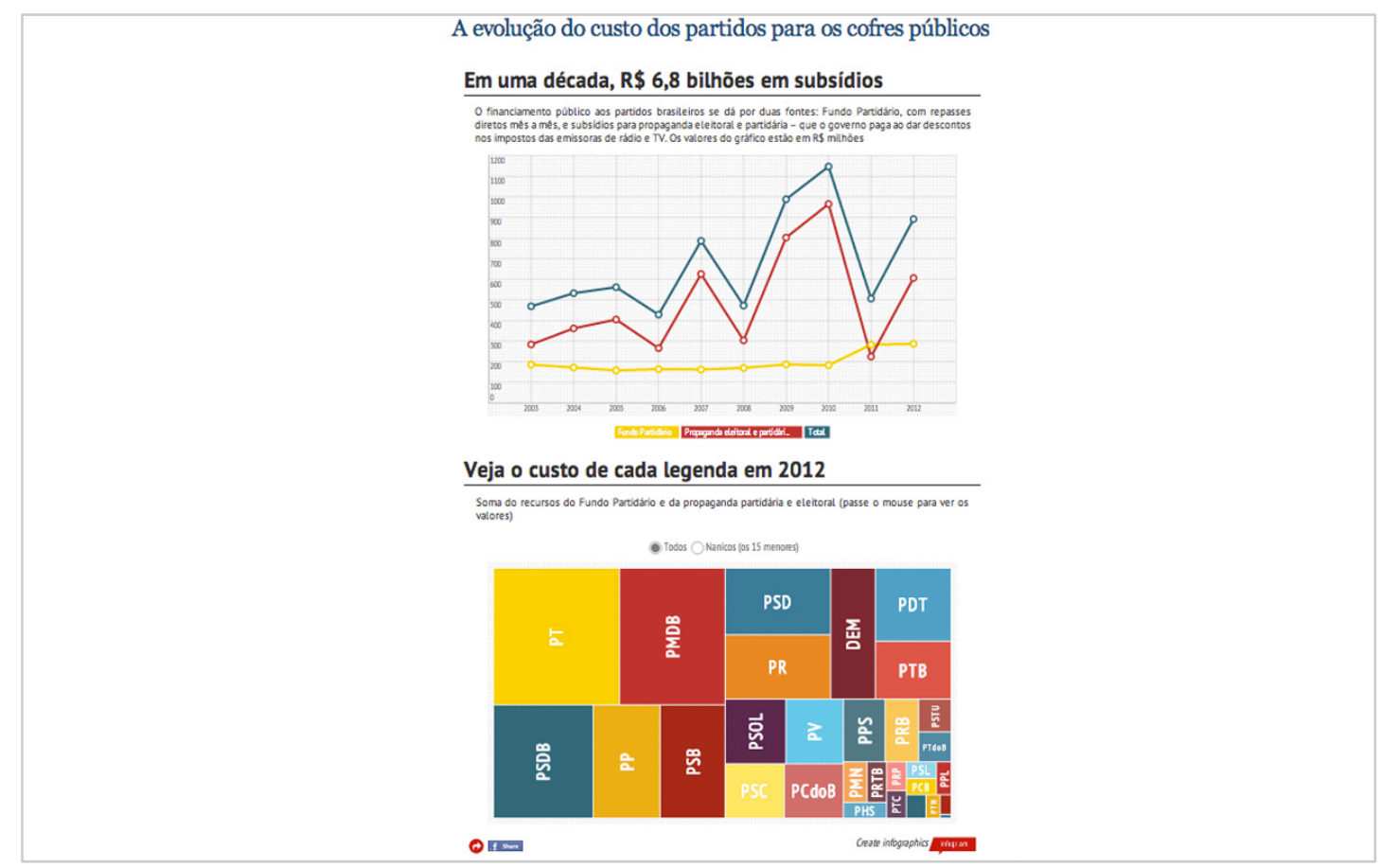

Figura 18 - A evolução do custo dos partidos para os cofres públicos - Uso do Infogr.am. Fonte: O Estado de S. Paulo, 2013. ${ }^{20}$

Não pretendemos associar o Infogr.am à proliferação de chartjunks, mas ressaltamos que todas as peças de nossa amostra criadas por meio dessa ferramenta de produção evidenciaram ao menos um dos seguintes problemas:

\footnotetext{
${ }^{19}$ Disponível em: <http://infogr.am/>.

20 Disponível em: <http://blog.estadaodados.com/veja-a-evolucao-do-custo-dos-partidos-para-os-cofrespublicos/>. Acesso em fev. 2014.
} 
- incompatibilidade ou contraste com o projeto gráfico do veículo de comunicação em termos de: escala de cor, tipografia, diagramação dos elementos visuais e textuais;

- compartimentação da informação em blocos: criação de duas ou mais representações gráficas com diferentes títulos, dispostas verticalmente na página, fragmentando o conteúdo e dificultando a relação entre os dados visualizados;

- modo de organização da informação não condizente com a natureza e relação dos dados que deveriam ser evidenciados.

Os problemas destacados reforçam a importância do tratamento gráfico da informação e da mediação do Design na produção de infovis customizados, cuja principal função deve ser gerar compreensão. Se ferramentas on-line e gratuitas, por um lado, avançam em termos de armazenamento e organização de dados, agilidade e baixo custo de produção de infovis, por outro, podem ser limitadas em termos de raciocínio e imaginação. Aplicativos de softwares baseados na web (APIs) necessitam da mediação dos profissionais para tornar valiosas as informações não porque as fazem simplesmente acessíveis e legíveis, mas, fundamentalmente, porque as tornam compreensíveis e relevantes por meio de estratégias do Design. Com a expansão dessas ferramentas on-line e gratuitas, a produção de infovis tende a ser ampliada para não especialistas, mas continua a exigir determinados conhecimentos específicos da teoria e técnica do Design da Informação para que a infografia alcance a excelência gráfica. Softwares inteligentes devem reforçar olhos e mentes dos comunicadores de modo a contribuir, com suas habilidades técnicas, para a organização e a apresentação da informação. Esse processo, porém, não é intuitivo nem totalmente pré-programado. Precisa ser estudado caso a caso, levando em conta a natureza dos dados e o objetivo da mensagem, tarefa que só um cérebro humano pode realizar.

Um modo de superar limitações tecnológicas seria conjugar o uso de ferramentas on-line e gratuitas à mediação e ao tratamento gráfico dos comunicadores, proporcionando o desenvolvimento de infovis customizados.

Cartograma (FSP_1203) (Figura 19), publicado pela Folha de S. Paulo em 29 de outubro de 2012, trata-se de um infovis que apresenta partidos ganhadores (agrupados por cor) nas eleições municipais brasileiras, em 2012, de acordo com o total de votos que receberam (evidência quantitativa) e distribuídos em um mapa 
(evidência geográfica). A peça é um dos dois infovis ${ }^{21}$ da amostra total que utilizam o aplicativo de software baseado na web (API) MapBox ${ }^{22}$ em suas produções. MapBox é, nos mesmos moldes do Google Fusion Tables, aplicativo especializado na codificação de dados em mapas interativos. O que torna essa peça especificamente interessante, no entanto, é o fato de ela apresentar uso da tecnologia API unido ao trabalho manual e de pesquisa dos profissionais.

A pesquisa e design dos polígonos do mapa foram feitos por Simon DuCroquet, artista gráfico da Folha, sob supervisão do editor Mario Kanno. A interatividade foi trabalhada pela equipe do FolhaSPDados utilizando o software de mapas MapBox (FALEIROS, 2012).

De fato, esforço criativo aliado à pesquisa centrada em teorias e práticas do Design destacam, em termos de excelência gráfica e impacto visual, o infovis Cartograma (Figura 19) dentre aqueles que são produzidos, em nossa amostra, por ferramentas de produção on-line e gratuitas.

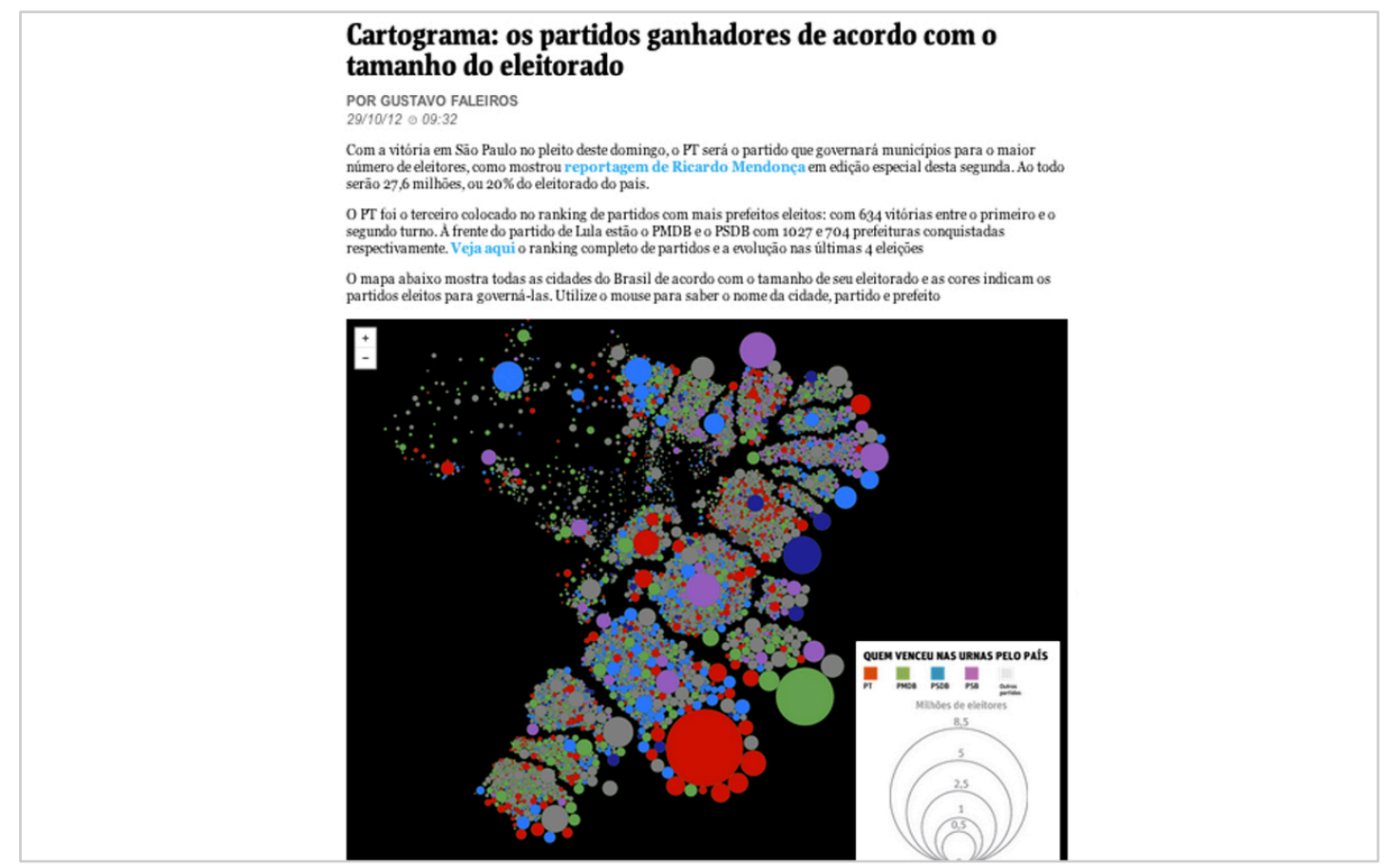

Figura 19 - Cartograma - Uso de Mapbox com tratamento gráfico da informação. Fonte: Folha de S. Paulo. ${ }^{23}$

\footnotetext{
${ }^{21}$ A outra peça é FSP_1204.

${ }^{22}$ Disponível em: <https://www.mapbox.com>.

${ }^{23}$ Disponível em <http://folhaspdados.blogfolha.uol.com.br/2012/10/29/cartograma-os-partidos-ganhadores-deacordo-com-o-tamanho-do-eleitorado/>. Acesso em mar. 2014.
} 
A esta altura, nos aproximamos de um ponto crucial para discussão acerca da utilização de tecnologias na produção de representações visuais, que instigou Kosara (2010) a perceber uma distinção entre o que seria, por um lado, infográfico, e, por outro lado, visualização, ${ }^{24}$ Para o autor, infográficos são, em teoria, produzidos manualmente e utilizados para conjuntos específicos de dados, enquanto visualizações são desenvolvidas de modo mais automático e pré-programado por ferramentas de produção - licenciadas ou gratuitas - que possibilitam aplicar uma mesma forma gráfica a diversos conjuntos de dados. Assim, infográficos se aproximariam mais do discurso jornalístico focado na mediação e narração de informações para situações e contextos específicos. Já visualizações seriam produtos de mecanismos mais automáticos e menos controlados, configurando modelos, por um lado, mais genéricos e descontextualizados e, por outro lado, menos "tratados" pelos comunicadores.

A distinção entre infográfico e visualização, realizada por Kosara, diz respeito a duas questões envolvidas no processo de produção de representações gráficas. A primeira, mais evidente, concerne à tecnologia de produção. A segunda, mais latente, aos efeitos que a tecnologia de produção pode trazer aos profissionais envolvido na produção de representações gráficas.

Sobre a primeira questão, tecnologia de produção, discordamos de que ela seja a base para determinar, isoladamente, o distanciamento entre infografia e visualização, como aponta Kosara. A nosso ver, todas as peças que compõem a amostra possuem, em graus diferentes, características de infográficos - posto que são produtos do jornalismo visual e possuem elementos estruturais que evidenciam uma narrativa com intenção informativa -, ao mesmo tempo que empregam a visualização da informação como modalidade de representação visual interativa e com base em dados, independentemente de configurarem peças customizadas ou templates ${ }^{25}$ produzidos, por exemplo, por aplicativos de softwares baseado na web (Tableau Public, Google Fusion Tables, etc.). Percebemos uma distinção entre infografia e visualização da informação não de exclusão, mas sim de abrangência e intencionalidade. Compreendemos a infografia como prática mais ampla que gera produtos jornalísticos

\footnotetext{
${ }^{24}$ Kosara (2010) prefere utilizar o termo visualization (visualização) a visualização da informação.

${ }^{25}$ Reiteramos que template é termo inglês, utilizado amplamente por profissionais do meio comunicativo, que designa documentos ou arquivos contendo unidades semântico-sintáticas básicas e preestabelecidas que servem de modelo inicial para um novo projeto.
} 
texto-visuais, customizados ou com base em templates, criados para fins predominantemente informativos que, para tal, conjuga conhecimentos teóricos e práticos do campo da Comunicação e do Design. Já a visualização da informação, interativa ou não, constitui modalidade de representação gráfica com qualidades que prescindem finalidades informativas e aplicações jornalísticas, no sentido de elucidar um fato, acontecimento ou ponto de vista objetivo e referencial. A visualização da informação consiste em processo de ampliação da cognição e do conhecimento, podendo exercer tais papéis tanto em discursos jornalísticos como em contextos de perspectiva mais artística, científica ou experimental. A nosso ver, portanto, não apenas as tecnologias envolvidas nas produções determinam intencionalidade e extensão de uso de visualizações da informação, mas, principalmente, o contexto e o tratamento gráfico-editorial a ela atribuídos. Diante de avanços tecnológicos, APIs e outras ferramentas gráficas tornam-se mais sofisticados e manipuláveis, possibilitando tanto a intervenção de designers quanto de não especialistas com conhecimento em Design. Nesse cenário, é mais comum encontrarmos representações gráficas que conjugam características da infografia e da visualização da informação, tal como o infovis.

A segunda questão diz respeito aos efeitos que a expansão de ferramentas online e gratuitas proporciona às equipes e práticas profissionais envolvidas na produção de infovis. Embora Kosara não seja explícito quanto a esse ponto, percebemos, por um lado, a associação da produção de infográficos customizados a profissionais especializados (designers e infografistas) e da produção de visualizações com base em templates a profissionais não especializados (jornalistas, no caso). Nesse sentido, concordamos que o desenvolvimento e os avanços em ferramentas de produção suprem algumas dificuldades técnicas e limitações criativas de não especialistas em Design da Informação, possibilitando, dessa forma, que jornalistas se tornem cada vez mais capazes e habilitados a assumir, em determinados casos, a produção de infovis - o encontro do infográfico com a visualização da informação interativa. Horn (2000 p. 26) enfatiza que a democratização de tecnologias de produção pode gerar tensões profissionais entre especialistas e não especialistas em Design na Informação. No entanto, com base no resultado da análise, não acreditamos que ferramentas de produção on-line e gratuitas ameacem ou substituam o papel de profissionais do Design na produção infográfica de forma geral, ao menos nas publicações analisadas na 
presente pesquisa. Projetos de infovis mais complexos exigem a combinação de conhecimentos e habilidades diferenciadas, além de um sistema de produção planejado e hierarquizado em funções de trabalho, o que dificilmente poderia ser realizado por apenas um profissional utilizando uma ferramenta. Cairo (2008, p. 84), ao exemplificar o caso do departamento de infografia do The New York Times, demonstra que, mesmo que um mesmo profissional possa desempenhar diferentes tarefas, normalmente o processo de produção de infográficos mais sofisticados é realizado por equipes interdisciplinares compostas, por exemplo, por redatores, programadores, repórteres e designers-infografistas, e envolve a combinação de diferentes softwares gráficos.

O uso de ferramentas on-line e gratuitas, como os APIs, para produção gráfica de infovis foi identificado em 66 peças da amostra, sendo 46 delas (70\%) publicadas em seções jornalísticas focadas em práticas de jornalismo de dados (Datablog, do The Guardian, Estadão de Dados, de O Estado de S. Paulo e FolhaSPDados, da Folha de S. Paulo). Portanto, há o indício de que o uso dessas ferramentas de produção não constitui uma tendência geral na prática de infovis nem pode ser associado, isoladamente, a um possível enfraquecimento do tratamento gráfico e de interface oferecidos pela equipe de designers, infografistas, programadores, etc., mas, a nosso ver, pode estar atrelado à consolidação das seções de jornalismo de dados e ao movimento open data ${ }^{26}$ que, juntos, incentivam jornalistas envolvidos em suas práticas a desenvolver posturas e habilidades interdisciplinares na coleta, análise e apresentação texto-visual dos dados.

\subsubsection{Atualização contínua}

A Tabela 2 (p. 121) apresenta o número de infovis que indicam utilização (65 peças ou $24 \%$ ) e não utilização (205 peças ou $76 \%$,) de tecnologia de atualização contínua dos dados. Do total dos 65 infovis que apresentam atualização contínua, 33 ( $12 \%$ da amostra total) pertencem ao The New York Times; 12 (4\% da amostra total) são do The Guardian; 11 (4\% da amostra total) pertencem ao O Estado de S. Paulo e 9 (3\% da amostra) são da Folha de S. Paulo

\footnotetext{
${ }^{26}$ Open data configura um movimento que apoia a transparência de determinados dados, da esfera pública ou privada, defendendo sua disponibilização ao público, de maneira acessível e gratuita, para que possam ser livremente circulados e reutilizados para diversos fins.
} 
Para Palacios, a instantaneidade ou atualização contínua é uma qualidade do jornalismo on-line que caracteriza "[...] rapidez do acesso, combinada com a facilidade de produção e de disponibilização, propiciadas pela digitalização da informação e pelas tecnologias telemáticas, permitem uma extrema agilidade de atualização do material nos jornais da Web" (PALACIOS, 2003, p.4). Rodrigues (2009) introduz a noção de atualização contínua aos infográficos da quarta fase do jornalismo on-line, as infobases. Para a autora, a atualização contínua é possibilitada pela tecnologia de base de dados incorporada à produção de infográficos e promove dinamismo e fluxo informacional dos dados visualizados.

Em nosso corpus de infovis de recorte político, atualização contínua configurase como importante qualidade para a cobertura eleitoral, evento que, concomitantemente, se enquadra como breaking news ${ }^{27}$ e possui momentos de fluxos informativos dinâmicos como, por exemplo, a apuração de votos. A respeito de uma possível relação mais estreita entre produção de infovis de cobertura eleitoral e uso de tecnologia de atualização contínua, o infografista Mario Cameira, do jornal português Público, comenta, em seu $b \log ,{ }^{28}$ a respeito de um infográfico desenvolvido pela publicação em ocasião da disputa presidencial entre Barack Obama e John McCain, nas eleições norte-americanas de 2008:

Pela primeira vez criamos infografias que, recorrendo a bases de dados, permitem a visualização da informação de forma dinâmica. Isto é, através de uma página web, inserem-se os dados que serão guardados numa base de dados, numa tabela de correspondência previamente estabelecida (CAMEIRA, 2008, n.p.).

De fato, se observarmos a presença da tecnologia de atualização contínua distribuída por temática no corpus da presente pesquisa (Gráfico 2), percebemos que, das 65 peças que apresentam esse recurso tecnológico, 55 pertencem ao tema 1 cobertura de eventos eleitorais - 10 pertencem ao tema 2 - instituições políticas nacionais que geram produtos e fatos - e nenhuma pertence ao tema 3 - escândalos políticos e casos de corrupção.

\footnotetext{
${ }^{27} \mathrm{O}$ jargão breaking news, em Jornalismo, caracteriza notícias que precisam ser veiculadas imediatamente, devido a seus valores de noticiabilidade e urgência.

${ }^{28}$ Disponível em: <http://infografando.blogspot.com.br/2008/10/os-eua-as-estatsticas-e-infografia.html>. Acesso em abr. 2014.
} 


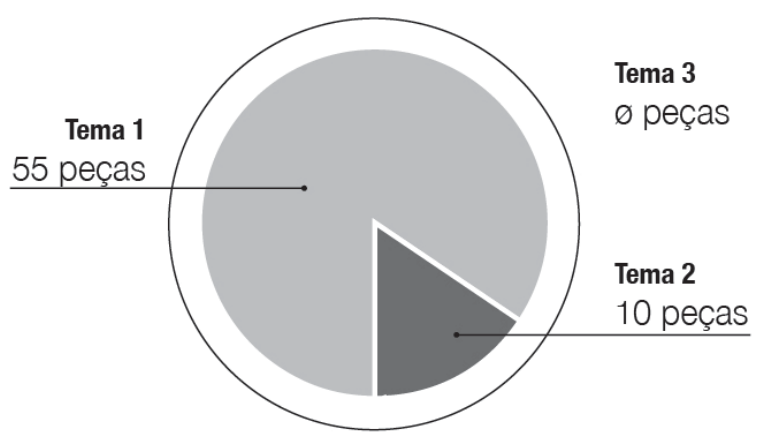

Gráfico 2 - Atualização contínua cruzada com temática. Fonte: elaboração própria.

A Figura 20 apresenta quatro infovis, um de cada veículo comunicativo analisado nessa pesquisa, que exemplificam a qualidade de atualização contínua na apresentação dos dados visualizados.

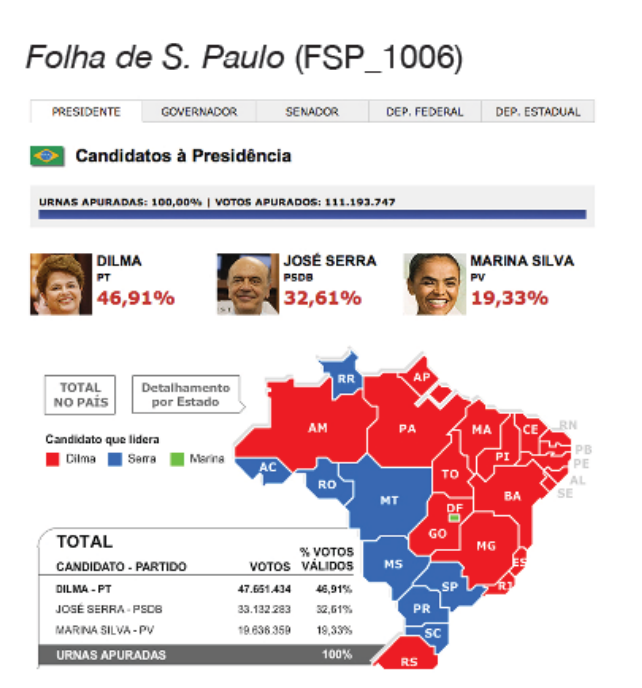

The Guardian (TGU_1307)

ngw: :

Campaign watch: 2013 Australian election interactive map

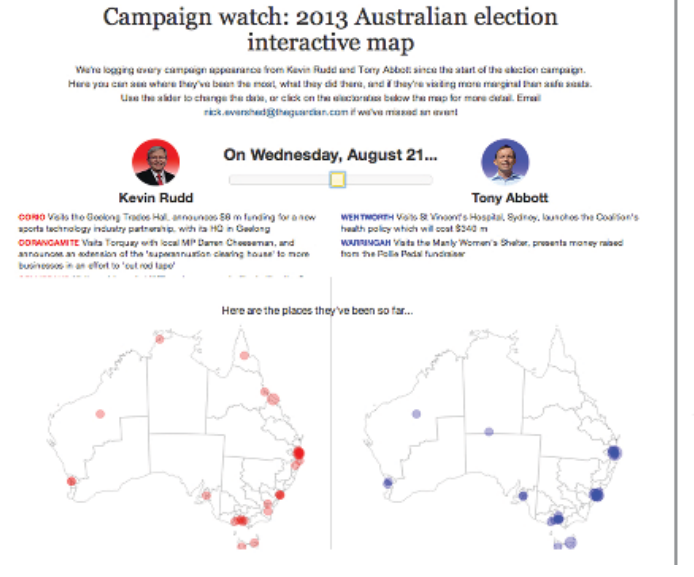

O Estado de S. Paulo (ESP_1005)

Geografia do voto
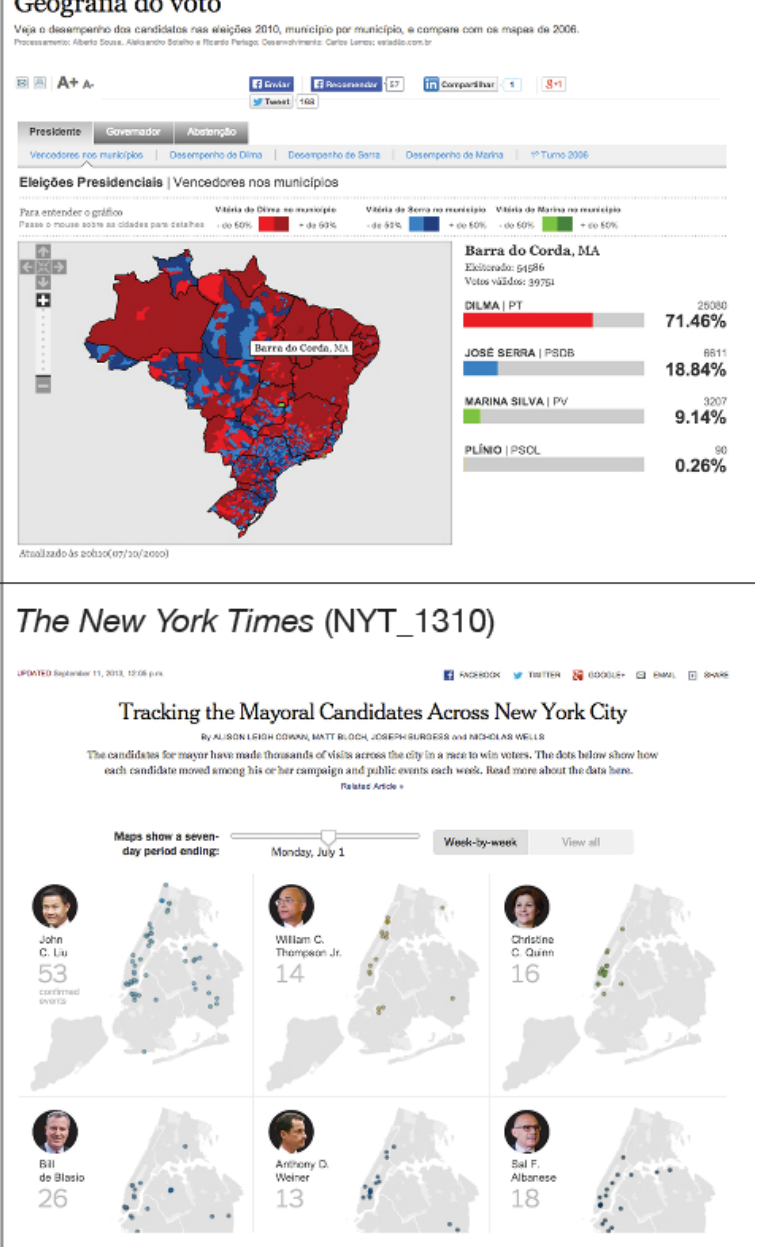

Figura 20 - Quatro infovis com qualidade de atualização contínua. Fonte: Folha de S. Paulo 2010; ${ }^{29}$

O Estado de S. Paulo, 2010; $;^{30}$ The Guardian, $2013^{31}$ e The New York Times, 2013. ${ }^{32}$

\footnotetext{
${ }^{29}$ Disponível em: <http://eleicoes.folha.uol.com.br/2010/1turno/apuracao-presidente.shtml>. Acesso em: jan. 2014.
} 
Na Figura 20, as peças Candidatos à Presidência (FSP_1006) e Geografia do voto (ESP_1005) apresentam distribuição de votos em tempo real, por estado e por município, respectivamente, para candidatos presidenciáveis durante as eleições de 2010, no Brasil. Já as peças Campaign watch (TGU_1307) e Tracking the Mayoral Candidates Across New York City (NYT_1310) monitoram visitas de candidatos em ocasião da campanha eleitoral para presidência da Austrália, em 2013, e para o governo de Nova York, em 2013, respectivamente.

A análise da subunidade atualização contínua permite inferir que, apesar de identificada em apenas 65 peças do corpus (24\% da amostra), essa tecnologia de produção configura-se como importante aspecto para o panorama atual e futuro de produção infográfica, pois agrega novos valores aos infovis desenvolvidos no suporte digital e on-line não só de temática política como também relacionados a outros assuntos. Em termos de novas práticas e significações para o discurso jornalístico, o atributo real time (tempo real) concede aos infovis qualidades semânticas e pragmáticas de monitoramento. Essa nova abordagem prática sobre os infovis contrasta com a tradicional visão de que a infografia produz representações gráficas para explicar e demonstrar fenômenos e processos ocorridos, que remetem ao passado, mesmo que recente. A sensação de instantaneidade e dinamicidade informativa promovidas pela tecnologia da atualização contínua e pela potencialidade do meio digital e em circulação on-line promove pioneiros usos jornalísticos para o infovis, que, em última instância, podem reconfigurar o estado da arte da infografia de modo geral.

\footnotetext{
${ }^{30}$ Disponível em: <http://www.estadao.com.br/especiais/geografia-do-voto,120705.htm>. Acesso em: jan. 2014.

31 Disponível em: <http://www.theguardian.com/world/datablog/interactive/2013/aug/19/australian-electioncampaign-map $>$. Acesso em dez. 2013.

${ }_{32}$ Disponível em: <http://www.nytimes.com/interactive/2013/08/01/nyregion/tracking-the-mayoral-candidatesacross-nyc.html>. Acesso em dez. 2013.
} 


\subsection{DIMENSÃO INTERFACE}

Tabela 3 - Resultados da dimensão interface de análise

\begin{tabular}{|c|c|c|c|c|c|c|c|c|}
\hline \multirow[t]{2}{*}{ Unidade } & \multirow[t]{2}{*}{ Subunidade } & \multicolumn{2}{|l|}{ Indicadores } & \multicolumn{3}{|c|}{ Ano de publicação } & \multirow[b]{2}{*}{2013} & \multirow[b]{2}{*}{ Tota } \\
\hline & & & & 2010 & 2011 & 2012 & & \\
\hline \multirow{5}{*}{$\begin{array}{l}.50 \\
\stackrel{5}{0} \\
0\end{array}$} & \multirow{5}{*}{$\begin{array}{l}\text { Modo de } \\
\text { organização da } \\
\text { informação }\end{array}$} & \multicolumn{2}{|l|}{ Quantitativo } & 56 & 10 & 67 & 73 & 206 \\
\hline & & \multicolumn{2}{|l|}{ Grupal } & 46 & 19 & 65 & 46 & 176 \\
\hline & & \multicolumn{2}{|l|}{ Conectivo } & 2 & 6 & 5 & 2 & 15 \\
\hline & & \multicolumn{2}{|l|}{ Temporal } & 18 & 13 & 16 & 38 & 85 \\
\hline & & \multicolumn{2}{|l|}{ Geográfico } & 33 & 5 & 36 & 25 & 99 \\
\hline \multirow{17}{*}{ 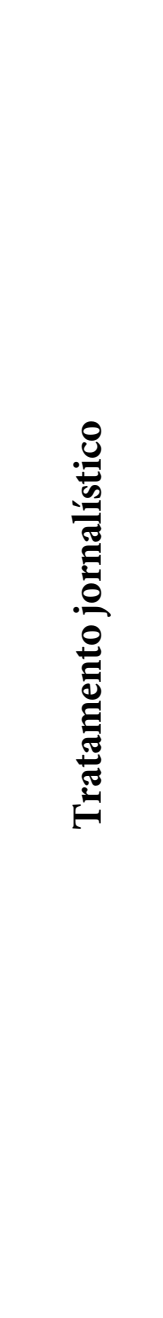 } & \multirow{6}{*}{ Temática } & \multicolumn{2}{|l|}{ Tema 1} & 48 & 10 & 65 & 38 & 161 \\
\hline & & \multicolumn{2}{|l|}{ Tema 2} & 16 & 17 & 13 & 49 & 95 \\
\hline & & \multicolumn{2}{|l|}{ Tema 3} & 2 & 2 & 4 & 6 & 14 \\
\hline & & \multicolumn{2}{|l|}{ Total } & 66 & 29 & 82 & 93 & 270 \\
\hline & & & & \multicolumn{4}{|c|}{ Veículo comunicativo } & \\
\hline & & & & NYT & TGU & FSP & ESP & Total \\
\hline & \multirow{11}{*}{$\begin{array}{l}\text { Gradiente } \\
\text { de mediação }\end{array}$} & Título & & 81 & 65 & 50 & 73 & 269 \\
\hline & & \multirow{2}{*}{$\begin{array}{l}\text { Texto } \\
\text { explicativo }\end{array}$} & Sim & 44 & 43 & 25 & 42 & 154 \\
\hline & & & Parcial & 12 & 21 & 19 & 31 & 83 \\
\hline & & \multicolumn{2}{|l|}{ Fonte } & 61 & 51 & 28 & 33 & 173 \\
\hline & & \multicolumn{2}{|l|}{ Crédito } & 56 & 65 & 31 & 67 & 219 \\
\hline & & \multicolumn{2}{|l|}{ Artigo } & 26 & 24 & 8 & 14 & 72 \\
\hline & & \multirow{2}{*}{ Nota } & Sim & 26 & 18 & 15 & 4 & 63 \\
\hline & & & Parcial & 30 & 19 & 15 & 28 & 92 \\
\hline & & \multirow{2}{*}{ Multimídia } & Sim & 15 & 12 & 19 & 9 & 55 \\
\hline & & & Parcial & 41 & 32 & 21 & 44 & 138 \\
\hline & & \multicolumn{2}{|l|}{ Média $^{34}$} & 5,89 & 6,52 & 5,8 & 5,39 & $5,89^{35}$ \\
\hline
\end{tabular}

Fonte: elaboração própria.

\footnotetext{
${ }^{33}$ Uma peça pode representar mais de um modo de organização da informação, simultaneamente.

${ }^{34}$ A média é a soma do gradientes de mediação de cada infovis dividida pelo número de peças do veículo comunicativo. $\mathrm{O}$ gradiente de mediação baseia-se na presença e ausência dos recursos do tratamento jornalístico e pode variar de zero a dez.

${ }^{35}$ A média total da amostra é calculada por média ponderada, ou seja, o quociente da soma dos produtos das médias pela soma dos respectivos pesos.
} 


\subsubsection{Modo de organização da informação}

A Tabela 3 demonstra que a evidência quantitativa constitui o modo de organização da informação predominante em nossa amostra de infovis com recorte político. A organização quantitativa de dados - que evidencia relações mensuráveis de variação e proporção - é visualizada em 208 infovis (77\%), seguida da organização grupal - que evidencia relações de junção ou separação de dados em classes -, presente em 177 infovis (65\%). Em terceiro lugar situa-se a organização geográfica - quando dados são representados em planos com disposição geográfica, como mapas -, visualizada em 99 peças (37\%). Logo após, figura a organização temporal - quando dados são representados em uma organização do plano que demonstra a passagem do tempo -, presente em 86 infovis (32\%). Por último, a organização conectiva - que evidencia relação de ligação entre dados, normalmente visualizada por meio de linhas ou setas conectoras - é frequente em apenas 15 infovis (6\%).

A maior incidência da organização quantitativa nos infovis analisados pode ser associada ao fato de a amostra possuir dimensão semântica majoritariamente de temática eleitoral (161 peças - 60\% do corpus - pertencem ao campo semântico cobertura de eventos eleitorais). O evento eleitoral, por sua vez, envolve extensa e variada rede de dados numéricos, como, por exemplo, números absolutos e percentuais de votos, campanha eleitoral e perfil demográfico do eleitorado. Os próprios instrumentos de pesquisa de opinião eleitoral (como Ibope e Datafolha) e de resultados eleitorais (como o TSE) implicam operações estatísticas, muitas vezes complexas, para evidenciar a frequência da ocorrência de eventos, tanto na observação de acontecimentos presentes como na previsão de fenômenos futuros. De fato, se observarmos a incidência do modo de organização quantitativo somente no universo temático cobertura de eventos eleitorais, o valor percentual aumenta de 77\% (na amostra total) para $84 \%$ (amostra recortada). A partir dos resultados, concluímos que a evidência quantitativa configura o modo predominante como o jornalismo coleta, medeia e comunica informações políticas, por meio do dispositivo infovis. A ênfase quantitativa, por sua vez, gera formas de pensar por meio de relações, comparações e evoluções numéricas, implicando consequências na maneira como dados são 
interpretados pelos consumidores da informação e como eles compreendem o campo político, sobretudo eventos eleitorais.

No entanto, se o modo de organizar a informação quantitativamente predomina em infovis da amostra, esse é raramente visualizado de forma isolada em uma mesma peça. Uma segunda perspectiva sobre a observação dos resultados da subunidade modo de organização da informação, apresentada na Tabela 3, nos permite analisar os infovis a partir de sua natureza primária ou híbrida (ENGELHARDT, 2002, p. 137-145). Embora Engelhardt não estabeleça diretamente essa definição, percebemos que representações gráficas consideradas primárias caracterizam-se por apresentar somente um modo de organização da informação e as consideradas híbridas caracterizam-se por apresentar dois ou mais modos de organização da informação. Há uma noção de hibridização da informação representada quando se passa de infovis primários para infovis híbridos, e tal hibridização pode ser compreendida em termos gradativos, se considerarmos que combinações - entre modos quantitativo, grupal, conectivo, temporal e geográfico -, em um mesmo infovis, pode ser de dois, três, quatro ou cinco modos de organização da informação. O Gráfico 3 apresenta a distribuição de infovis da amostra por natureza primária, híbrida com dois modos de organização da informação, híbrida com três modos de organização da informação e assim por diante.

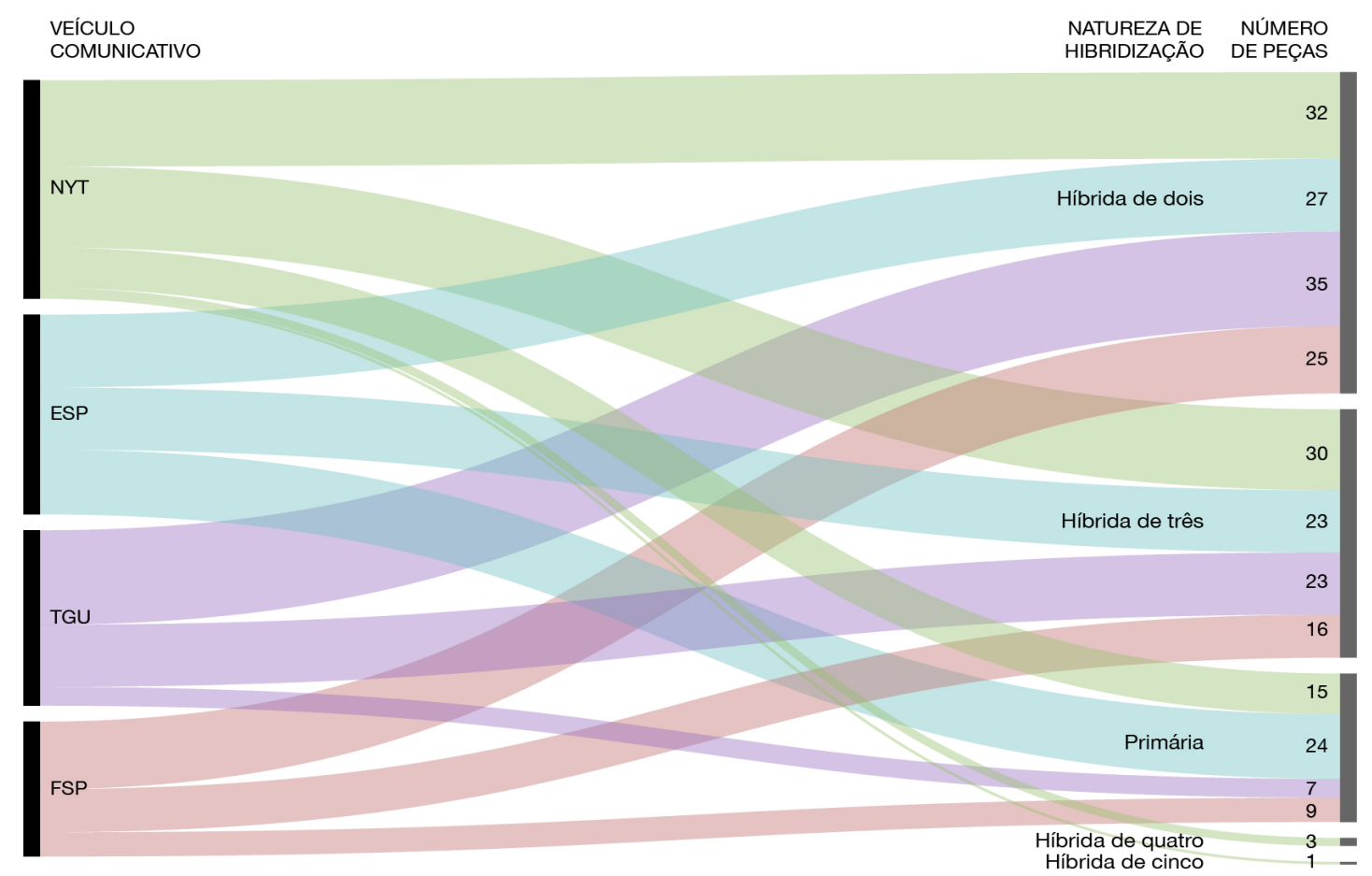

Gráfico 3 - Distribuição de infovis por natureza de hibridização e por veículo comunicativo. Fonte: elaboração própria utilizando a ferramenta Raw. 
O Gráfico 3, que elaboramos por meio da ferramenta on-line e gratuita $R a w,{ }^{36}$ demonstra que o número de infovis de natureza primária totaliza 55 peças $(20 \%$ da amostra) enquanto o número de infovis de natureza híbrida, em todas as suas gradações, alcança 215 peças ( $80 \%$ da amostra). Há, portanto, em todas as publicações maior incidência de peças híbridas a despeito das primárias, o que nos permite inferir que existe uma tendência geral de produção de infovis com cruzamento de diferentes modos de organização informativa. Observando as gradações de natureza híbrida, no entanto, percebemos que a maior parte das peças, em todos os veículos comunicativos, caracteriza-se por apresentar dois modos de organização da informação (119 peças, ou $44 \%$ da amostra), seguida do hibridismo de três modos de organização da informação (92 peças, ou 34\% da amostra). Apenas quatro peças (menos de $2 \%$ da amostra) apresentam quatro ou mais modos de organização da informação, todos, nesse caso, pertencentes à publicação The New York Times.

Para exemplificar a gradação da hibridização informativa, apresentamos, a seguir, cinco infovis de nossa amostra que possuem ao menos um modo de organização quantitativo: o primeiro de natureza primária, e os quatro seguintes representando gradações da natureza híbrida, com dois a cinco modos de organização da informação. O motivo de selecionarmos exemplos exclusivamente do The New York Times a despeito dos outro veículos jornalísticos deve-se ao fato de que a publicação é a única que possui peças primárias e híbridas em todas gradações.

At the Democratic Convention, the Words Being Used (NYT_1220) (Figura 21), publicado pelo The New York Times em 4 de setembro de 2012, trata-se de infovis com apenas um modo de organização da informação, no caso, quantitativo. A peça apresenta círculos correspondentes às palavras (Obama, Work, Jobs, Families, etc.) mencionadas por líderes do partido democrata, o candidato presidencial Barack Obama entre eles, na Convenção Nacional Democrata. A área dos círculos (variável visual tamanho) evidencia visual e comparativamente relações quantitativas com base na incidência da cada palavra no total dos discursos transcritos (por exemplo, o nome de Obama é mencionado 664 vezes, enquanto o nome de Bin Laden é repetido em 29 ocasiões). Dessa forma, círculos maiores indicam palavras mais frequentes no

\footnotetext{
${ }^{36}$ Raw constitui um aplicativo de software baseado na web (API), desenvolvido pela equipe do laboratório de pesquisa Density Design Lab, do Politécnico de Milano, para criação de visualizações. Raw está disponível em: $<$ http://app.raw.densitydesign.org/>. Acesso em mai. 2014.
} 
discurso dos líderes democratas, enquanto círculos menores representam palavras menos recorrentes. Assim como esse infovis, a peça At the Republican Convention, the Words Being Used (NYT_1221) (37 $^{37}$ contabiliza as palavras mencionadas por líderes republicanos na Convenção Nacional Republicana e estabelece igual modo de organização da informação. Já a peça At the National Conventions, the Words They Used (NYT_1219) ${ }^{38}$ apresenta simultaneamente a incidência das palavras mencionadas por democratas e republicanos e, para tal, faz uso de um segundo modo de organização da informação, grupal, que separa por meio da variável visual cor duas categorias, republicano em azul e democrata em vermelho.

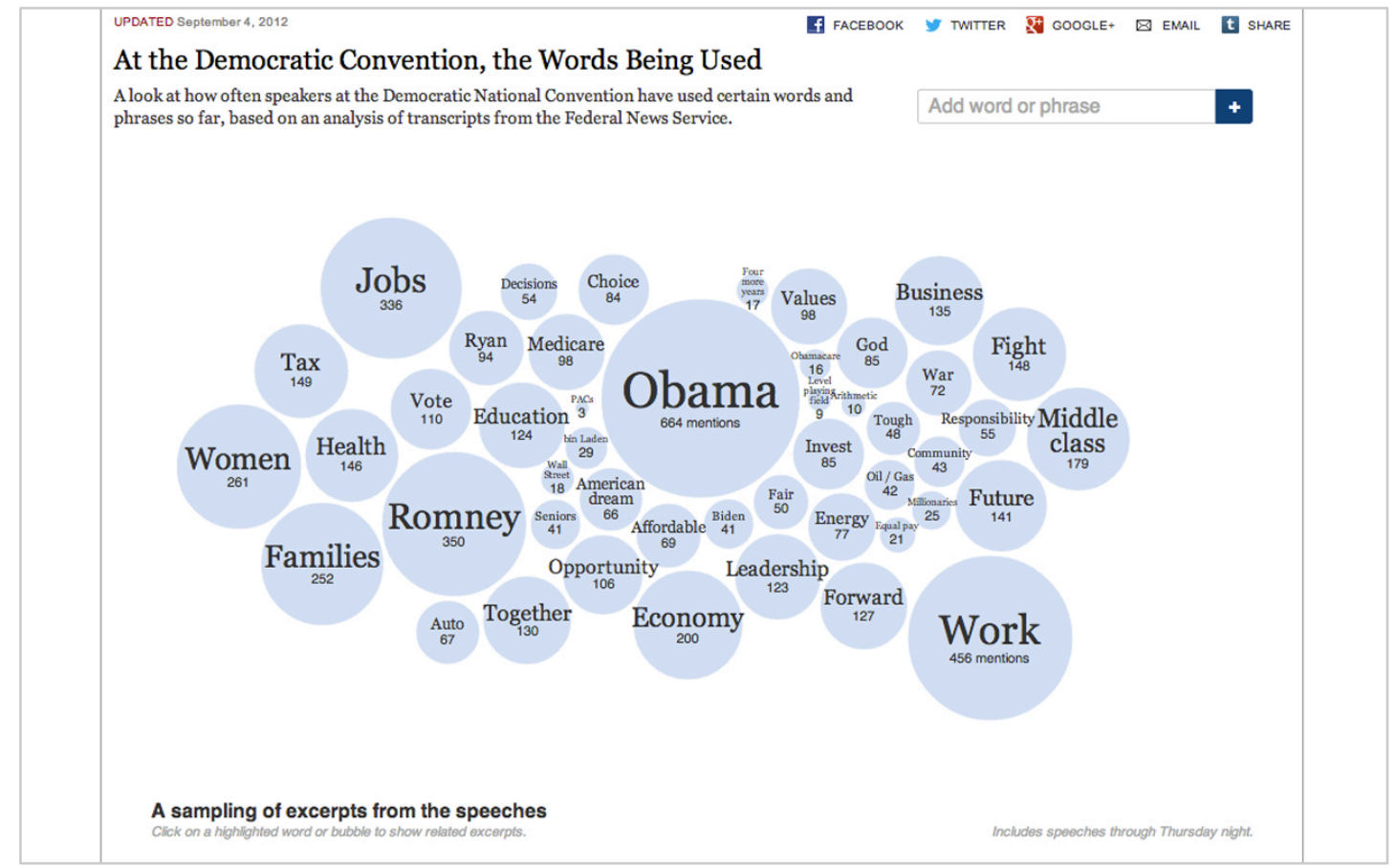

Figura 21 - At the Democratic Convention, the Words Being Used - Infovis de natureza primária. Fonte: The New York Times, 2012. ${ }^{39}$

Obama's 2011 Budget Proposal (NYT_1017) (Figura 22), publicado pelo The New York Times em 1ำ de fevereiro de 2010, trata-se de infovis com dois modos de organização quantitativos e uma evidência de organização grupal. A peça apresenta retângulos maiores, com borda branca mais espessa, correspondentes aos setores

\footnotetext{
${ }^{37}$ Disponível em <http://www.nytimes.com/interactive/2012/08/28/us/politics/convention-word-counts.html $>$ jan. 2014.

38 Disponível em <http://www.nytimes.com/interactive/2012/09/06/us/politics/convention-word-counts.html>. Acesso em jan. 2014.

39 Disponível em: <http://www.nytimes.com/interactive/2012/09/04/us/politics/democratic-convention-words. html> Acesso em: jan. 2014.
} 
públicos (Defesa Nacional, Segurança Social, Saúde, Transporte, etc.) que agrupam seus subsetores representados pelos retângulos menores coloridos. A área dos retângulos (variável visual tamanho) é proporcional à quantidade de dinheiro (em bilhão) reservada a cada setor e subsetor públicos. Shneiderman (1996, p. 3) denomina esse tipo de representação gráfica treemap, estrutura hierárquica com noção de encapsulamento dos elementos representados em níveis de informação. A variação de cor e tom dos retângulos indica outra evidência quantitativa, o percentual de mudança orçamentária entre 2010 e 2011 - tons vermelhos indicam diminuição do orçamento para um subsetor específico em relação ao ano anterior, enquanto tons em azul indicam aumento. Outras peças de nossa amostra de modo de organização da informação semelhante ao desse infovis são Obama's 2012 Budget Proposal: How \$3.7 Trillion is spent (NYT_1110) ${ }^{40}$ e Four Ways to Slice Obama's 2013 Budget Proposal (NYT_1229). ${ }^{41}$

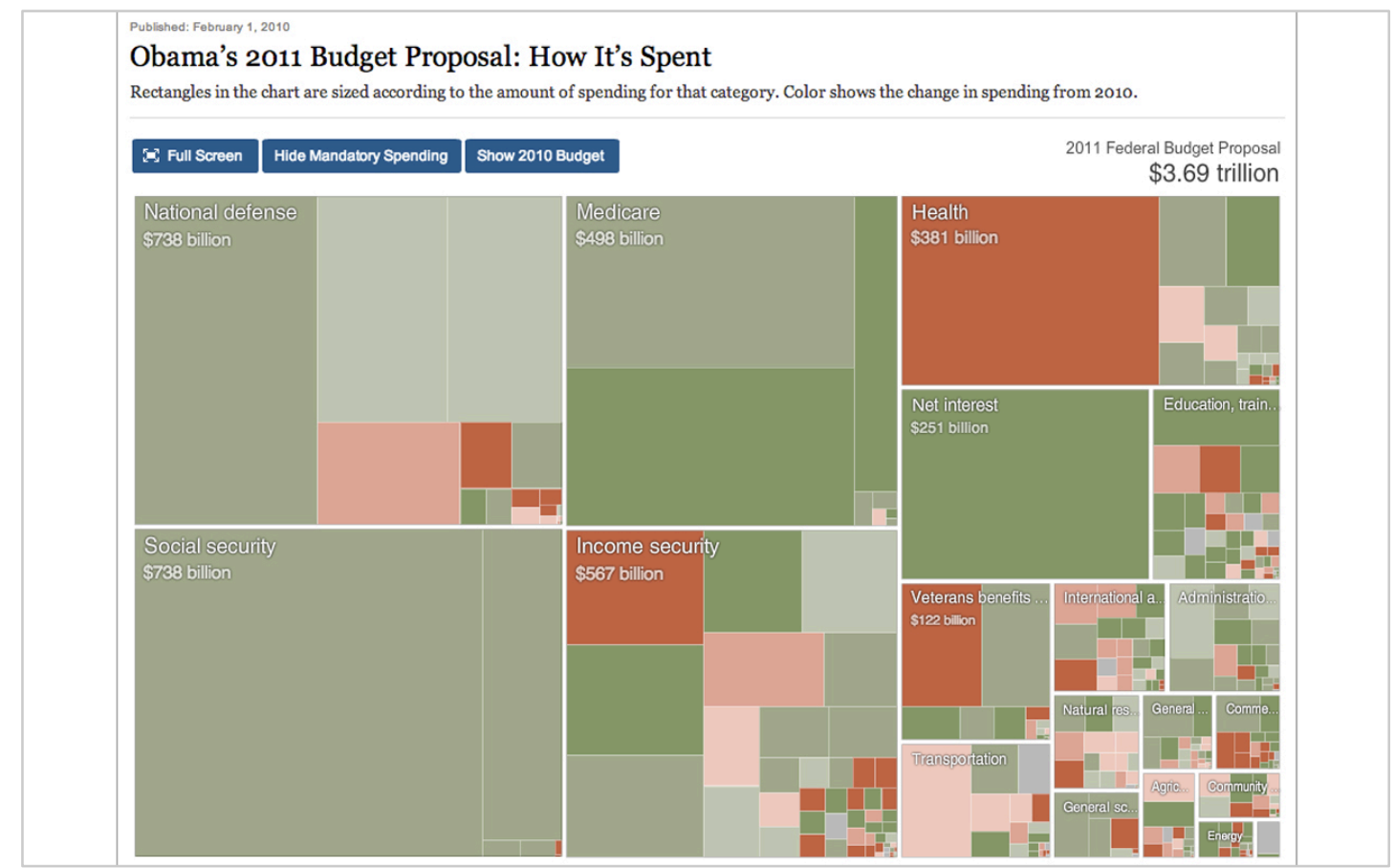

Figura 22 - Obama's 2011 Budget Proposal - Infovis com modo de organização quantitativo e grupal. Fonte: The New York Times, 2010. ${ }^{42}$

The Electoral Map (NYT_1210) (Figura 23), publicado pelo The New York Times em 2012, compõe, em sua tela inicial, um infovis com três modos de

\footnotetext{
${ }^{40}$ Disponível em: <http://www.nytimes.com/packages/html/newsgraphics/2011/0119-budget/>. Acesso em jan. 2014.

${ }^{41}$ Disponível em <http://www.nytimes.com/interactive/2012/02/13/us/politics/2013-budget-proposal-graphic. html $>$. Acesso em jan. 2014.

${ }^{42}$ Disponível em: <http://www.nytimes.com/interactive/2010/02/01/us/budget.html>. Acesso em jan. 2014.
} 
organização da informação: quantitativo, grupal e geográfico. A peça é composta de retângulos posicionados nas duas dimensões do plano que correspondem, por associação geográfica, ao estados dos Estados Unidos. As áreas dos quadrados, que representam cada estado, são escalonadas proporcionalmente (evidência quantitativa) a valores a elas associados, no caso o número de votos eleitorais que cada estado possui em eleições presidenciais. Cairo ([2013], p. 20) classifica esse tipo de mapa como cartograma e afirma que, para a representação ser percebida e compreendida como um mapa (evidência geográfica), é necessário que ela mantenha, mesmo que grosseiramente, certas relações espaciais como posição e fronteira entre cidades, estados ou países.

O infovis estabelece uma organização grupal, cujas cores e tonalidades de cada estado associam-se ao candidato presidencial com maior probabilidade de vitória no local (Obama, representado em azul, e Romney, representado em vermelho) ou à situação de um possível empate (representada em amarelo).

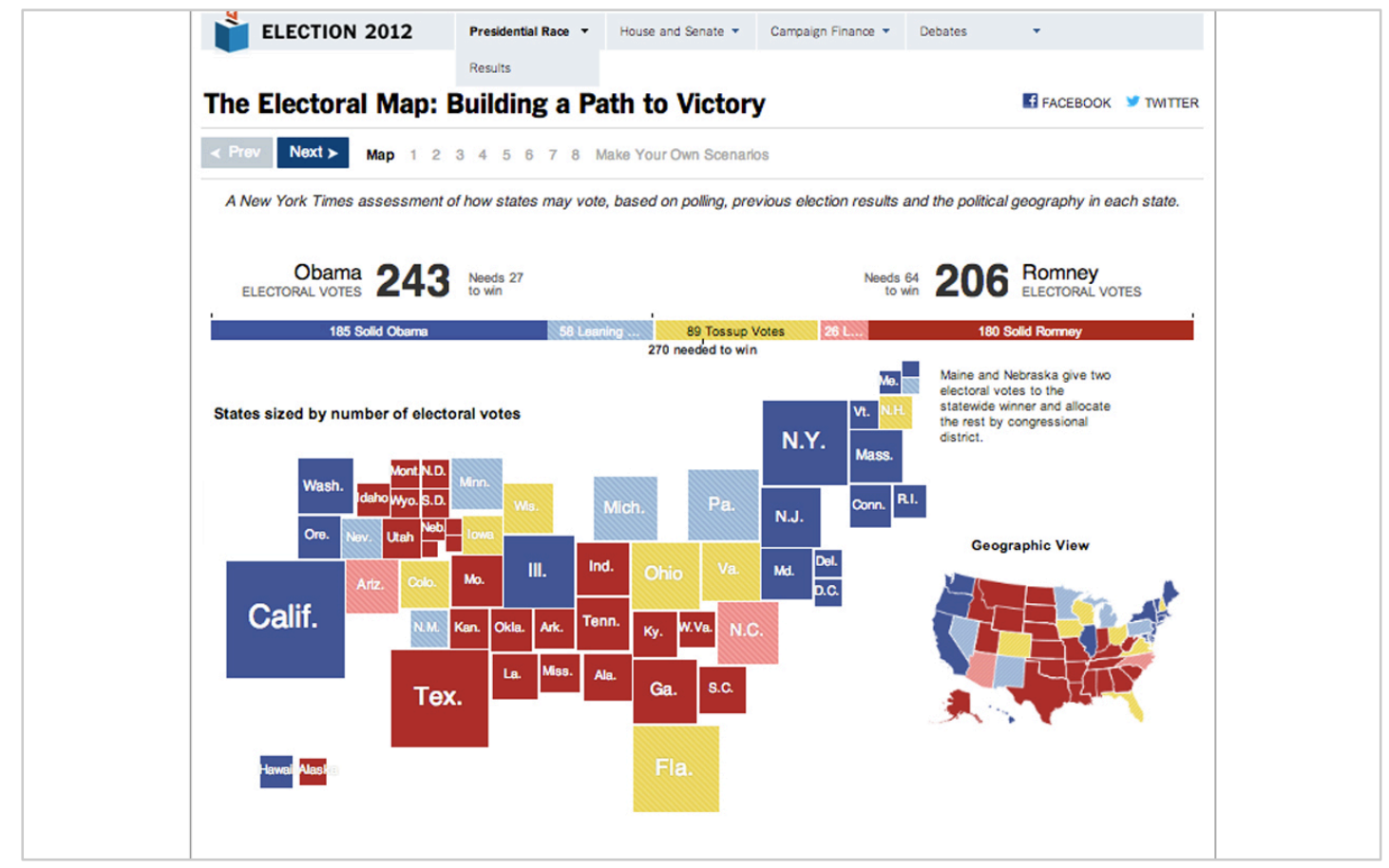

Figura 23 - The Electoral Map - Infovis com modo de organização quantitativo, grupal e geográfico. Fonte: The New York Times, 2010. ${ }^{43}$

Over the Decades, How States Have Shifted (NYT_1217) (Figura 24), publicado pelo The New York Times em 7 de novembro de 2012, trata-se de infovis

\footnotetext{
${ }^{43}$ Disponível em: <http://elections.nytimes.com/2012/ratings/electoral-map >. Acesso em fev. 2014.
} 
com quatro modos de organização da informação: quantitativo, grupal, conectivo e temporal. Infovis com quatro ou mais modos de organização da informação são de mais difícil rotulação segundo alguma classificação tipológica de representações gráficas, mas, com as devidas ressalvas, poderíamos enquadrar a presente peça como série temporal (TUFTE, 1983), que caracteriza estruturas sintáticas nas quais uma variável informativa oscila em função do tempo. No entanto, a complexidade informativa e visual do infovis em questão indica que mais de uma variável informativa varia em função do tempo.

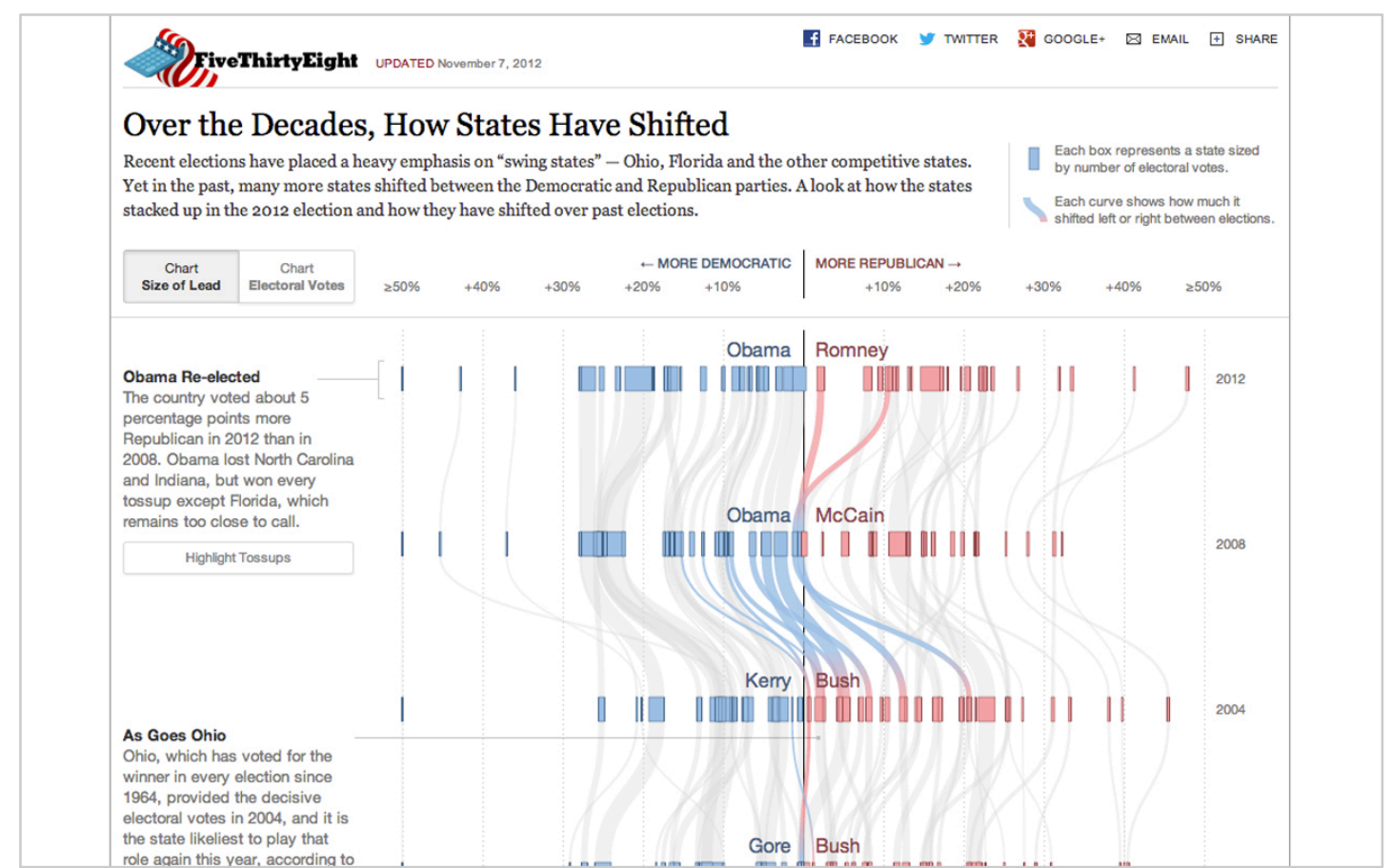

Figura 24 - Over the Decades, How States Have Shifted - Infovis com quatro modos de organização. Fonte: The New York Times, 2012. ${ }^{44}$

A peça apresenta a variação da preferência partidária dos estados norteamericanos ao longo das eleições presidenciais. No nível macro, dados representados são organizados segundo duas dimensões do plano (eixos horizontal e vertical). $O$ eixo vertical organiza as 16 últimas eleições presidenciais norte-americanas em ordem decrescente (evidência temporal). E o eixo horizontal indica percentual (evidência quantitativa) de preferência partidária de cada estado por democratas ou republicanos, distanciados por posição e cor (evidência grupal): do lado esquerdo e

\footnotetext{
${ }^{44}$ Disponível em: <http://www.nytimes.com/interactive/2012/10/15/us/politics/swing-history.html>. Acesso em fev. 2014.
} 
em azul são representados estados com preferência por democratas com percentual de vitória na região entre 1 e 50\% contra o partido republicano; do lado direito, em vermelho, ocorre o inverso.

No nível micro, o infovis apresenta a maneira como cada estado norteamericano oscila sua preferência partidária por candidatos presidenciais democratas e republicanos em números percentuais em função do tempo. A evidência conectiva é percebida por meio das linhas conectoras entre retângulos que, por sua vez, representam estados, aos longo das distintas eleições. Assim, linhas conectoras demonstram o fluxo variável de preferência partidária de cada estado nas últimas 16 eleições presidenciais dos Estados Unidos. Direção e ângulo das linhas conectoras apontam alternância e intensidade de preferência partidária; e sua espessura indica a força representativa de cada estado na decisão eleitoral a partir do número de votos concedidos a cada um.

$\mathrm{O}$ último infovis analisado nesta seção, The Election Will Be Tweeted (and Retweeted) (NYT_1009) (Figura 25), publicado pelo The New York Times em 2010, trata-se de uma representação gráfica de natureza híbrida com cinco modos de organização da informação (quantitativo, grupal, conectivo, temporal e geográfico). Da mesma forma que consideramos o infovis anterior (Figura 24) série temporal, a Figura 25 poderia ser classificada como narrativa espaço-temporal (TUFTE, 1983), um tipo de representação gráfica no qual determinada variável informativa, além de variar em função do tempo, é distribuída espacialmente em um plano com referências geográficas.

A peça apresenta número de tweets $^{45}$ relacionados aos candidatos ao governo e senado dos Estados Unidos nas eleições de 2010 publicados por usuários comuns, em período determinado de tempo (entre os dia 21 de outubro e 4 de novembro de 2010). Círculos representam candidatos ao governo e senado, enquanto suas cores (vermelho, azul ou cinza) agrupam candidatos do mesmo partido (Republicano, Democrata ou independente). As áreas dos círculos (evidência quantitativa) apontam o número de tweets em que candidatos foram mencionados, constituindo-se como valores indicativos de suas visibilidades midiáticas. Círculos são

\footnotetext{
${ }^{45}$ Mensagens com até 140 caracteres postadas por meio da rede social Twitter.
} 
georreferenciados ${ }^{46} \mathrm{em}$ um plano dimensional composto de seis quadrantes que correspondem às regiões dos Estados Unidos (Noroeste, Nordeste, Sudoeste, Sudeste e duas regiões centrais não nomeadas). Relações entre posição e fronteira entre estados do país não são mantidas, o que impossibilita a percepção cognitiva da representação como um mapa. No entanto, consideramos o georreferenciamento por região uma evidência geográfica.

Os modos de organização conectivo e temporal são observados à medida que usuários interagem com o dispositivo infovis. Uma linha do tempo é construída acima do plano no qual os círculos são dispostos. Ao interagir com ela, avançando ou retrocedendo no tempo, as áreas dos círculos oscilam, indicando variação de tweets direcionados a cada candidato em função do dia e horário. Ao passar o mouse sobre um círculo específico, revelam-se relações de ligação entre candidatos oponentes a um mesmo cargo.

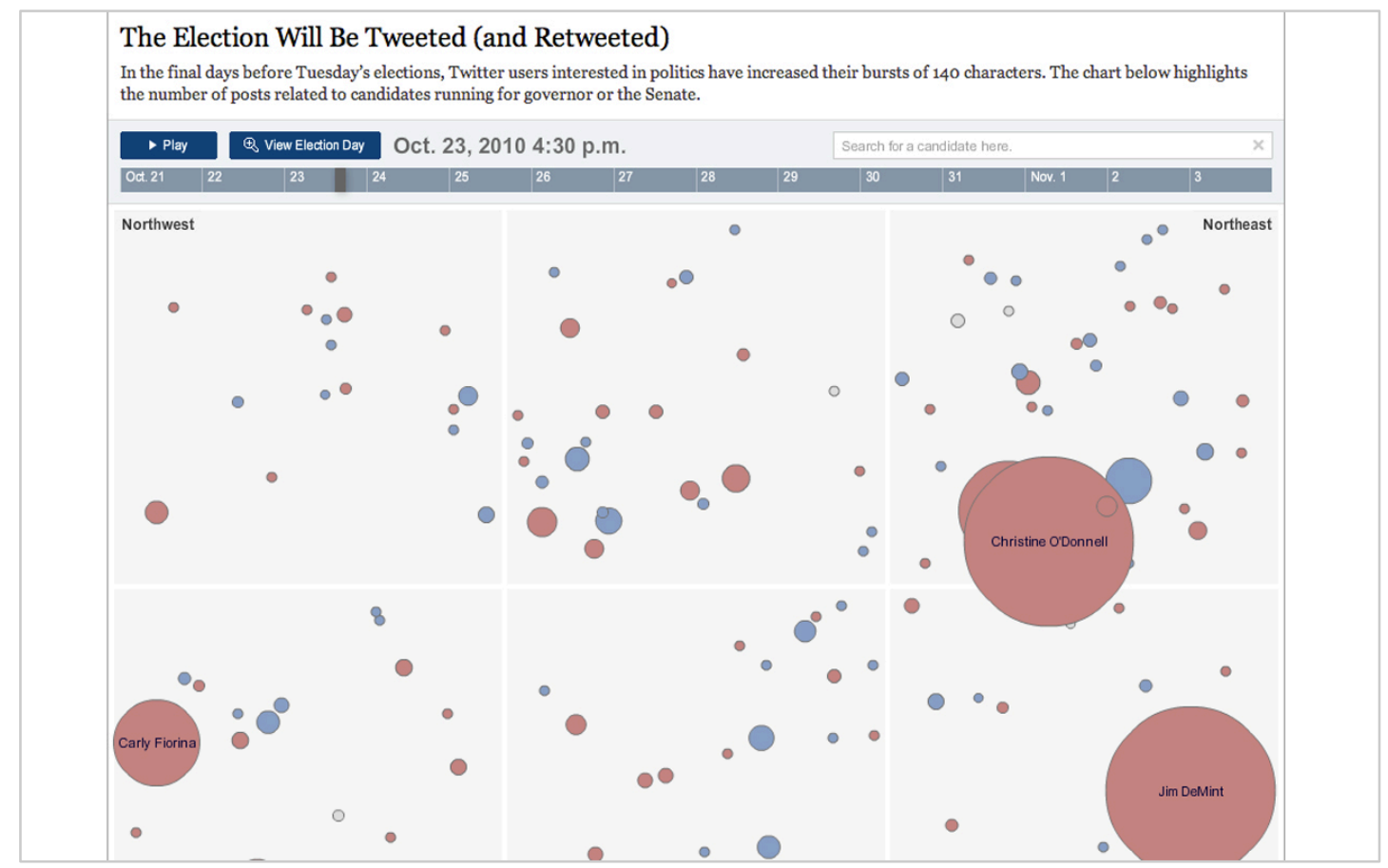

Figura 25 - The Election Will Be Tweeted (and Retweeted)- Infovis com cinco modos de organização. Fonte: The New York Times, 2010. ${ }^{47}$

A peça apresentada na Figura 25 é infovis de alto grau de hibridização que, ao apresentar, simultaneamente, todos os cinco modos de organização da informação

\footnotetext{
${ }^{46}$ Georreferenciar uma imagem, um mapa ou qualquer outra forma de informação geográfica significa tornar suas coordenadas conhecidas em um dado sistema de referência.

${ }^{47}$ Disponível em: <http://www.nytimes.com/interactive/us/politics/2010-twitter-candidates.html>. Acesso em fev. 2014.
} 
classificados por nós, demonstra complexidade e profundidade visual-informativa reveladas por meio do cruzamento de diferentes conjuntos de dados.

A escassez de infovis que apresentam as duas últimas gradações de hibridismo (quatro ou cinco modos de organização da informação) deve-se ao fato de que nem sempre é necessário cruzar e organizar dados em diversos modos informativos para que o conteúdo, sobre determinado assunto, seja representado e compreendido, bastando um ou dois modos de organização (quantitativo e temporal, por exemplo). Entretanto, o conteúdo político, sobretudo eleitoral, envolve complexidade e simultaneidade informativa que justificariam presença de mais peças com quatro ou cinco modos de organização da informação em nosso corpus. Por isso, percebemos um segundo fator pelo qual poucas peças apresentam gradações mais altas de hibridização: a conjugação de diferentes modos de organizar e visualizar informações implica a criação de infovis com mais camadas de profundidade, recursos interativos e arquiteturas de navegação mais coesas. Esses elementos, por sua vez, dependem de maior despendimento de tempo e trabalho, assim como mais profissionais envolvidos na produção infográfica em redações.

O cruzamento informativo talvez constitua uma das chaves para expandir a compreensão do mundo e ampliar a aquisição de conhecimento e, embora não seja uma tendência concreta no corpus analisado - pois dependem de mais conhecimentos técnicos, assim como de engajamento profissional -, representa uma frente pioneira na produção infográfica.

\subsubsection{Temática}

A leitura dos dados da Tabela 3 (p. 136) não permite estabelecer, de forma explícita, um padrão de crescimento para produção de infovis de assunto político, embora a produção em 2013 (93 peças) seja 29\% maior em relação a 2010 (66 peças). Podemos, no entanto, analisar o comportamento do crescimento produtivo cruzando dados de ano de publicação com editoria. Se observamos o comportamento dos dados da Tabela 3 por meio da subunidade de análise temática, devemos atentar para o fato de que o tema 1 - cobertura de eventos eleitorais - predomina na amostra desta pesquisa como assunto principal em 161 peças (60\%), seguido do tema 2 - instituições 
políticas que geram produtos e fatos -, presente em 95 infovis (35\%), e, por último, aparece o tema 3 - escândalos políticos e casos de corrupção -, que incide em 14 peças (5\%). Dessa forma, observando a predominância do tema 1 na amostra, a razão de 2011 apresentar queda brusca na produção de infovis, em nosso corpus, pode ser atribuída ao fato de nenhum evento político eleitoral importante ter acontecido nesse período nos países das publicações analisadas (Estados Unidos, Reino Unido e Brasil). Já em 2010, houve eleições presidenciais e legislativas no Brasil, eleições para governo, senado e câmara no Estados Unidos e eleições parlamentares no Reino Unido. Em 2012, ocorreram eleições presidenciais e legislativas nos Estados Unidos, eleições municipais no Brasil (prefeitos e vereadores) e eleições municipais no Reino Unido. Finalmente, em 2013, aconteceram eleições municipais nos Estados Unidos e eleições locais no Reino Unido. Portanto, podemos concluir que a produção infográfica aumenta ou diminui segundo fatores contextuais, e, especificamente em nossa amostra, a realização de eventos eleitorais constitui uma força motriz que incide sobre o crescimento produtivo de infovis.

Enquanto as publicações The New York Times, The Guardian e Folha de S. Paulo apontam diminuição no número de infovis de conteúdo político de 2012 para 2013 (o que pode ser atribuído ao fato de o segundo ano ser, em relação ao primeiro, mais importante em termos de eventos políticos eleitorais em todas as nações dessas publicações), o veículo comunicativo O Estado de S. Paulo apresenta um considerável crescimento de $208 \%{ }^{48}$ na produção de infovis Esse aumento, que não necessariamente significa crescimento qualitativo, foge ao comportamento-padrão apresentado pelos outros veículos comunicativos e pode ser relacionado ao comportamento de outra subunidade de análise, editoria.

Estadão de Dados, ${ }^{49}$ definido como "[...] reportagens baseadas em estatísticas e no desenvolvimento de projetos especiais de visualização de dados” (ESTADÃO DADOS, 2014), constitui seção exclusivamente on-line de O Estado de S. Paulo, criada em 2012 e consolidada em 2013. A seção, comandada pelo Grupo Estado, representa iniciativa pioneira em publicações jornalísticas brasileiras e espelha-se na seção Datablog, ${ }^{50}$ do The Guardian, caracterizada por reunir "[...] dados brutos por

\footnotetext{
${ }^{48}$ Identificamos 12 infovis de conteúdo político do O Estado de S. Paulo publicados em 2012 e 37 publicados em 2013.

${ }^{49}$ A seção está disponível em: <http://blog.estadaodados.com>. Acesso em fev. 2013.

${ }^{50}$ A seção está disponível em: <http://www.theguardian.com/news/datablog $>$.
} 
de trás das notícias para você explorar, visualizar e debater" (DATABLOG, 2012) e que se propõe a produzir reportagens com base em estatísticas e a desenvolver projetos especiais de visualização de dados. O ex-editor do The Guardian, Simon Rogers, comenta a seção:

O Guardian Datablog, que eu edito, era para ser um pequeno blog oferecendo as bases de dados completas por trás de nossas matérias. Agora ele consiste em uma página inicial; buscas de dados sobre países e desenvolvimento global; visualização de dados de artistas gráficos do Guardian e de outras partes da rede e ferramentas para exploração de dados sobre gastos públicos. Todos os dias, usamos as planilhas do Google para compartilhar todos os dados por trás de nossos trabalho; visualizamos e analisamos esses dados e, então, os usamos para criar reportagens no jornal e no site (ROGERS, 2014).

A criação de seções jornalísticas especializadas em jornalismo de dados, como os já mencionados Datablog e Estadão de Dados e também o FolhaSPDados, ${ }^{51}$ do Grupo Folha, subintitulada "Para visualizar, analisar e compartilhar dados”, permitenos inferir uma segunda força que impulsiona produções de infográficos tanto de temática política como de outros conteúdos semânticos, particularmente aqueles interativos e representativos de dados quantitativos e categóricos, o que os caracteriza como infovis. ${ }^{52}$ Dessa forma, podemos associar o aumento de $208 \%$ na produção de infovis de O Estado de S. Paulo, de 2012 para 2013, à consolidação da seção Estadão de Dados, responsável pela publicação de 29 das 37 peças (78\%) produzidas pelo veículo comunicativo, em 2013.

A partir da identificação dos nomes das editorias ou seções de cada infovis analisado por meio de títulos e retrancas da página web, classificamos-as como tradicionais ou especiais. A primeira categoria diz respeito às editorias fixas tradicionais do sítio jornalístico, como Política, Mercado, Cidade, Mundo, Cultura, Opinião e suas variações terminológicas; a segunda equivale a seções criadas para eventos específicos ou exclusivamente para plataforma on-line da publicação projetos especiais visando à cobertura eleitoral, seções de jornalismo de dados como

\footnotetext{
${ }^{51}$ A seção está disponível em: <http://folhaspdados.blogfolha.uol.com.br>.

${ }^{52}$ Vale mencionar que o veículo The New York Times também chegou a criar, em 2008, uma seção especializada na produção e compartilhamento de visualizações de dados, o The New York Times Visualization Lab (Vizlab). Embora a seção se encontre inativa, a produção de infovis continua sendo realizada em seções tradicionais do sítio.
} 
Datablog, Estadão Dados e FolhaSPDados, e outras seções especiais exclusivas do ambiente on-line como Infográficos e blogs)..$^{53}$

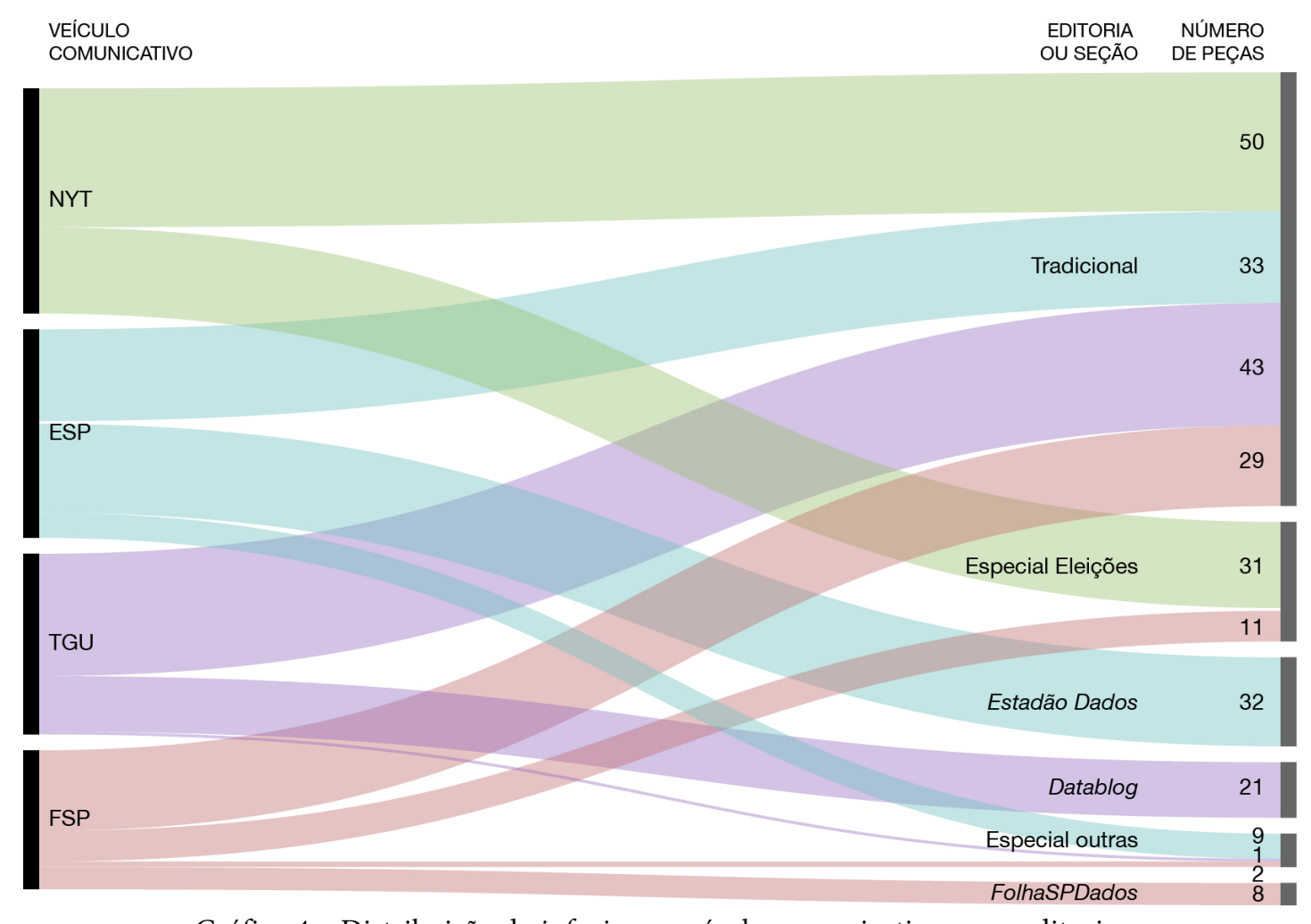

Gráfico 4 - Distribuição de infovis por veículo comunicativo e por editoria.

Fonte: elaboração própria utilizando a ferramenta Raw.

O Gráfico 4 nos permite observar que, embora a maioria das peças (155 infovis ou 57\%) pertençam a editorias tradicionais, considerável parcela de infovis (115 ou 43\%) enquadra-se na categoria projetos especiais ou seções especializadas em jornalismo de dados. Dos 115 infovis agrupados em Especiais, 42 peças (15\% da amostra total) pertencem a páginas criadas especificamente para coberturas eleitorais de seus respectivos veículos. Já as seções Estadão Dados (de O Estado de S. Paulo) (Figura 26), Datablog (do The Guardian), e FolhaSPDados (da Folha de S. Paulo) são responsáveis por $12 \%$ (32 peças), $7 \%$ (21 peças) e 3\% (8 peças), respectivamente, do total de infovis analisados, o que corresponde a $22 \%$ do corpus da pesquisa.

\footnotetext{
${ }^{53}$ A identificação das editorias e seções de cada infovis foi realizada no período de codificação das peças, entre dezembro de 2013 e fevereiro de 2014. Após esse período, O Estado de S. Paulo reformulou seu sítio e alterou o endereço web e a editoria de alguns de seus infovis.
} 


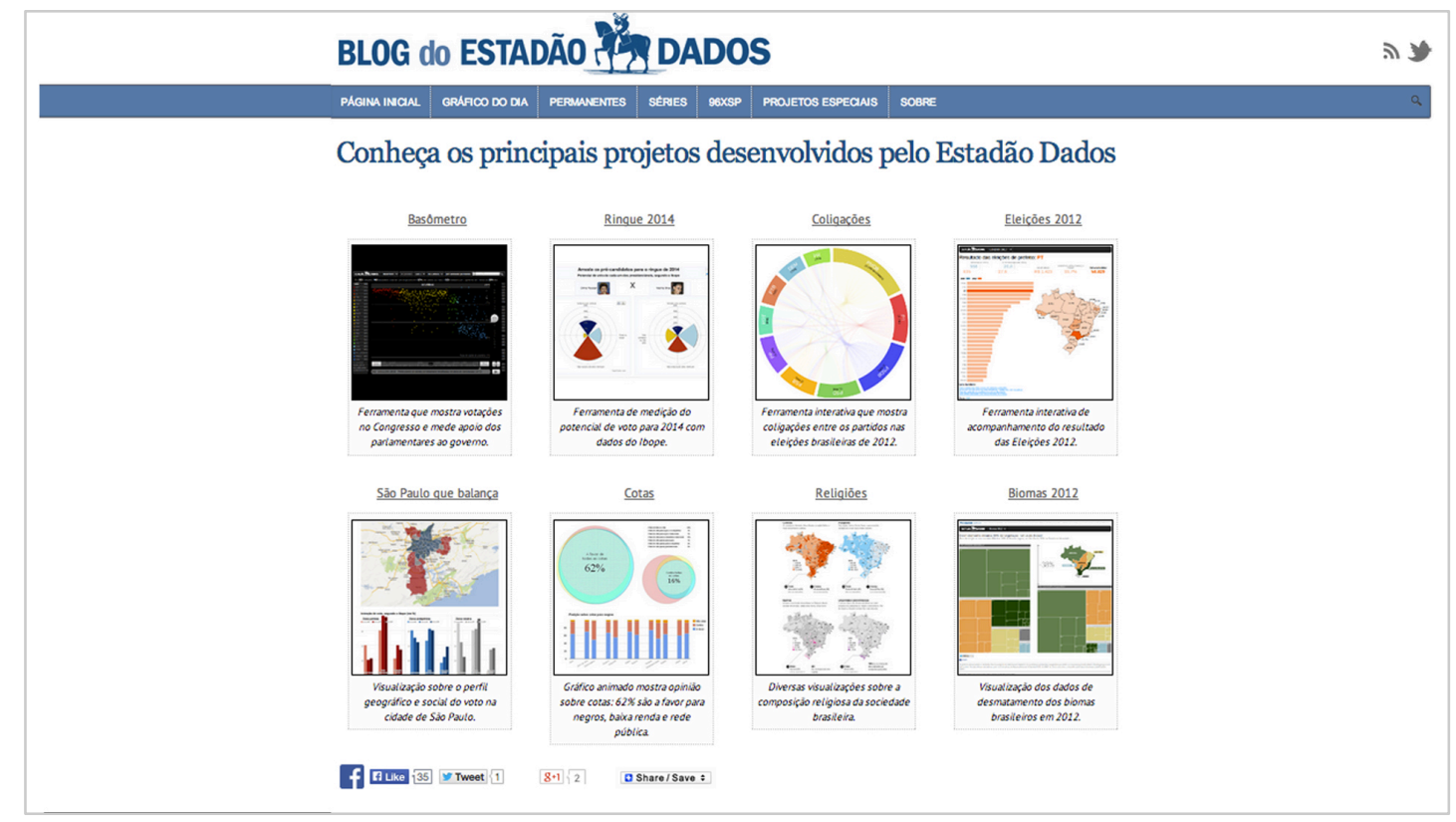

Figura 26 - Estadão de Dados - Seção especializada em jornalismo de dados. Fonte: O Estado de S. Paulo, 2014..$^{54}$

Dessa forma, a análise da subunidade editoria representa uma expansão de nossa conclusão quanto ao aumento produtivo de infovis, na amostra analisada, estar relacionado à ampliação de acontecimentos de repercussão política. Observamos movimento paralelo que delineia uma reconfiguração do modelo de produção jornalística, dos tradicionais critérios de noticiabilidade - que definem o exercício jornalístico a partir da cobertura e publicação de acontecimentos sociais considerados relevantes - para novos paradigmas de fazer jornalismo e, consequentemente, elaborar produtos jornalísticos, com base em posturas mais observadoras e curadoras dos profissionais diante dos dados disponíveis. Os dados, por sua vez, são produtos de pesquisa e descoberta e não representam, necessariamente, acontecimentos factuais. Muitas vezes, dados são resultado de práticas orientadas para a investigação e adquirem valor-notícia à medida que são tratados e interpretados, ou seja, coletados, cruzados, organizados, contextualizados e, finalmente, representados por meio da mediação de jornalistas e designers.

\footnotetext{
${ }^{54}$ Disponível em: <http://blog.estadaodados.com/projetos-estadao-dados>. Acesso em mai. 2014.
} 


\subsection{DIMENSÃO OUTPUT}

Tabela 4 - Resultados da dimensão output de análise

\begin{tabular}{|c|c|c|c|c|c|c|c|}
\hline \multirow[t]{2}{*}{ Unidade } & \multirow[t]{2}{*}{ Subunidade } & \multirow[t]{2}{*}{ Indicadores } & \multicolumn{5}{|c|}{ Veículo comunicativo } \\
\hline & & & NYT & TGU & FSP & ESP & Total \\
\hline \multirow{11}{*}{ 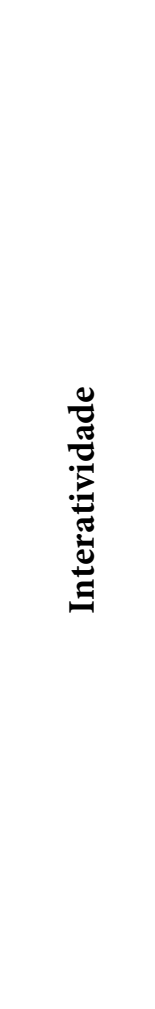 } & \multirow{11}{*}{$\begin{array}{l}\text { Gradiente de } \\
\text { interatividade }\end{array}$} & $\begin{array}{l}\text { Avançar/retro- } \\
\text { ceder ou iniciar }\end{array}$ & 21 & 8 & 13 & 15 & 57 \\
\hline & & Roll over & 69 & 42 & 28 & 69 & 208 \\
\hline & & Zoom & 22 & 14 & 11 & 21 & 68 \\
\hline & & Filtragem & 22 & 6 & 7 & 16 & 51 \\
\hline & & Relação & 14 & 7 & 7 & 5 & 33 \\
\hline & & Busca & 11 & 11 & 2 & 2 & 26 \\
\hline & & Extração & 0 & 18 & 0 & 6 & 24 \\
\hline & & Customização & 25 & 24 & 6 & 7 & 62 \\
\hline & & $\begin{array}{l}\text { Outro painel } \\
\text { de controle }\end{array}$ & 62 & 51 & 34 & 35 & 182 \\
\hline & & Hipertextualidade & 27 & 9 & 10 & 22 & 68 \\
\hline & & Média $^{55}$ & 3,37 & 2,9 & 2,36 & 2,68 & $2,88^{56}$ \\
\hline \multirow{6}{*}{ } & \multirow{2}{*}{ Comentário } & Sim & 2 & 17 & 15 & 28 & 62 \\
\hline & & Não & 79 & 48 & 35 & 46 & 208 \\
\hline & \multirow{2}{*}{$\begin{array}{l}\text { Compartilha- } \\
\text { mento }\end{array}$} & Sim & 79 & 65 & 34 & 74 & 252 \\
\hline & & Não & 2 & 0 & 16 & 0 & 18 \\
\hline & \multirow{2}{*}{$\begin{array}{l}\text { Conteúdo } \\
\text { gerado pelo } \\
\text { usuário }\end{array}$} & Sim & 5 & 5 & 0 & 0 & 10 \\
\hline & & Não & 76 & 60 & 50 & 74 & 260 \\
\hline
\end{tabular}

Fonte: elaboração própria.

\footnotetext{
${ }^{55}$ A média é a soma do gradientes de interatividade de cada infovis dividida pelo número de peças do veículo comunicativo. O gradientes de interatividade é baseado na presença ou ausência dos recursos interativos de exploração do conteúdo e pode variar de zero a dez.

${ }^{56}$ Média ponderada é o quociente da soma dos produtos das médias pela soma dos respectivos pesos.
} 


\subsubsection{Gradiente de mediação versus gradiente de interatividade}

Retornando aos dados sobre a subunidade gradiente de mediação na Tabela 3 (p. 136) e os comparando com dados da subunidade gradiente de interatividade apresentados na Tabela 4, obtemos o seguinte panorama:

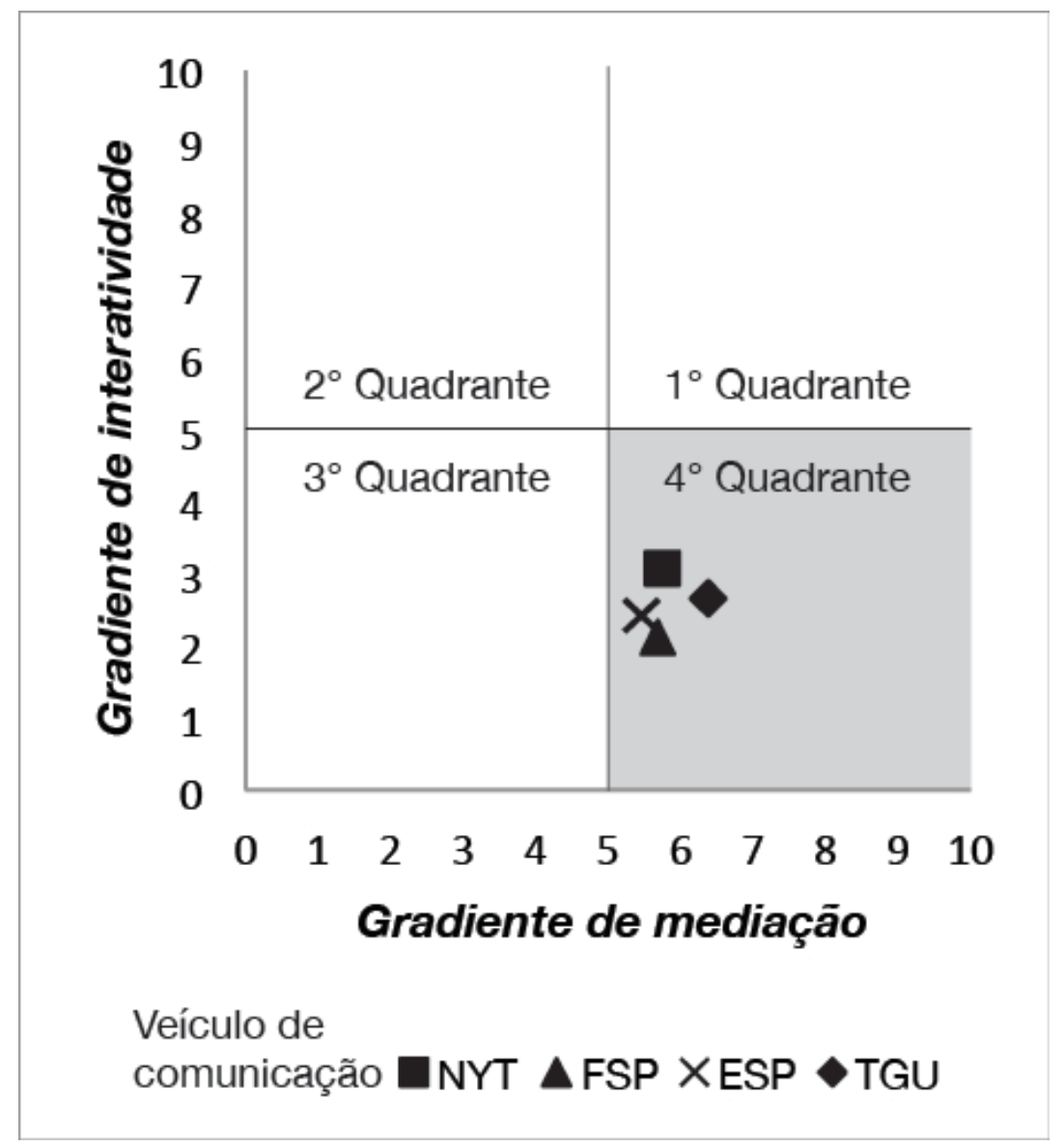

Gráfico 5 - Média do gradiente de mediação e do gradiente de interatividade, por veículo comunicativo Fonte: elaboração própria.

O Gráfico 5 apresenta a pontuação ${ }^{57}$ média do gradiente de mediação (eixo $\mathrm{X}$ ) - que atribui valor de zero a dez à mediação do dispositivo infovis com base na presença total, parcial ou ausência dos atributos do tratamento jornalístico ${ }^{58}-\mathrm{e}$ do gradiente de interatividade (eixo Y) - que concede valor de zero a dez à interatividade daquele dispositivo com base na presença ou ausência dos recursos interativos de

\footnotetext{
${ }^{57}$ Para normalizar os valores e permitir comparação, a pontuação de cada infovis, em cada publicação, foi somada e dividida pelo número de peças, gerando uma média.

${ }^{58}$ Título, texto explicativo, fonte, crédito, artigo, nota e multimídia.
} 
exploração do conteúdo ${ }^{59}$ - do conjunto de peças de cada veículo de comunicação analisado. O Gráfico 5 aponta um padrão de médias localizadas no quarto quadrante, o que significa que peças de todas as publicações tendem a apresentar valores médios de gradiente de mediação superiores aos valores médios de gradiente de interatividade. Embora as médias das publicações apresentem valores bastante próximos, é possível notar que infovis do The New York Times apresentam maior índice médio para gradiente de interatividade (média de 3,37), enquanto peças do The Guardian indicam maior índice médio para gradiente de mediação (média de 6,52). Além disso, a Folha de S. Paulo apresenta a menor pontuação para gradiente de interatividade (média de 2,36) e O Estado de S. Paulo apresenta a menor pontuação para gradiente de mediação (média de 5,39). A Tabela 5 reúne os valores médios dos gradientes em números absolutos:

Tabela 5 - Média de gradientes de mediação e de gradiente de interatividade por veículo comunicativo

\begin{tabular}{lll}
\hline Veículos comunicativos & $\begin{array}{l}\text { Média de gradiente } \\
\text { de mediação }\end{array}$ & $\begin{array}{l}\text { Média de gradiente } \\
\text { de interatividade }\end{array}$ \\
\hline The New York Times & 5,89 & 3,37 \\
The Guardian & 6,52 & 2,9 \\
Folha de S. Paulo & 5,39 & 2,36 \\
O Estado de S. Paulo & 5,39 & 2,67 \\
Total & 5,89 & 2,88 \\
\hline
\end{tabular}

Fonte: elaboração própria.

A Tabela 5 expõe média baixa (inferior a 4) para gradiente de interatividade em todos os veículos comunicativos, comparativamente à média alcançada em gradiente de mediação (superior a 5). Logo, constatamos a subutilização dos recursos interativos de exploração do conteúdo que caracterizam a interatividade do tipo usuário/conteúdo - avançar/retroceder ou iniciar, roll over, zoom, filtragem, relação, busca, extração, customização, outro painel de controle, e hipertextualidade - a despeito dos recursos de mediação, que caracterizam, tradicionalmente, o discurso narrativo jornalístico - título, texto explicativo, fonte, crédito, artigo, nota e

\footnotetext{
${ }^{59}$ Avançar/retroceder ou iniciar, roll over, zoom, filtragem, relação, busca, extração, customização, outro painel de controle, e hipertextualidade.
} 
multimídia. A subutilização, por sua vez, está associada ao fato de a emergência de narrativas mais interativas e audiovisuais, como o dispositivo infovis, fazer parte de ambientes complexos mais amplos. A incorporação de recursos interativos para exploração do conteúdo, em contextos jornalísticos, envolve, ademais de profissionais com conhecimentos específicos, suportes estruturais em rede e todos os elementos que configuram seu back office, isto é, sistemas de base de dados, softwares variados, uso de APIs e linguagens de programação, etc. Longe de estabelecer um determinismo tecnológico, esses elementos devem superar suas dimensões de artefatos tecnológicos para tornar-se constitutivos da prática e processo de produção jornalística (SCHWINGEL, 2012). A implementação de tais artefatos, no entanto, não constitui desafio isolado para comunicação jornalística. Ela depende de processos complexos e integrados que determinam a forma como conteúdos informativos são coletados, editados, organizados e circulados para que usuários possam interagir com o dispositivo infovis envolvendo, portanto, a cultura e o exercício jornalístico em sua totalidade:

[...] o produto mediático não é o ponto de partida no fluxo. Pode muito bem ser visto como um ponto de chegada, como consequência de uma série de processos, de expectativas, de interesses e de ações que resultam em sua composição como "um objeto para circular" - e que, por sua vez, realimenta o fluxo da circulação (BRAGA, 2012a, p. 30, grifo original).

Alguns setores jornalísticos, que compõem uma disciplina tradicionalmente conservadora, passam por momentos de reestruturação de suas práticas produtivas, adequando seus fazeres e ideais às dinâmicas e lógicas do ciberespaço que abrangem transformações advindas da passagem da mídia impressa à digital e on-line, da estrutura linear do texto escrito à logica hipertextual e multimídia, do discurso centralizado e unidirecional à comunicação interativa e dialógica. Essas questões configuram mudanças paradigmáticas que afetam o modelo de negócio das organizações de comunicação, alteram o modus operandi dos profissionais (jornalistas e designers) nas fases de apuração, produção e circulação do conteúdo e, em última análise, repercutem na atuação e participação do receptor, agora devidamente um usuário ou, se preferirmos, interagente, no consumo mais ativo do conteúdo.

Finalmente, se produtos midiáticos dependem do processo produtivo jornalístico em sua totalidade, afetando exercícios dos profissionais e dinâmicas de 
trabalho, devemos considerar, também, que uma possível ampliação da utilização de recursos interativos, em dispositivos infovis, depende de fatores como: 1) redações com equipes maiores e/ou com editorias específicas para a produção infográfica; 2) melhor integração entre os profissionais (jornalistas, designers, programadores, entre outras funções) envolvidos no processo produtivo e 3) maior planejamento e tempo para a produção infográfica.

\subsubsection{Abordagens direcionadas pelo autor e pelo usuário}

Retomando conceito proposto por Segel e Heer (2010) que fundamentou a base teórica para a análise comparativa entre gradientes de mediação e de interatividade, a visualização narrativa constitui uma classe emergente de visualizações que contam histórias a partir de dados e, para isso, combinam potencialidades comunicativas e narrativas da interface do dispositivo (analisadas, em nossa análise, por meio das unidades design e tratamento jornalístico) com recursos interativos (analisadas, em nossa análise, por meio da unidade interatividade) que permitem exploração do conteúdo. Comunicar mensagens consiste, para os autores, no uso de elementos textuais para promover comentários e explanações mediadas sobre imagens. A interatividade, por sua vez, que não deixa de ser assistida e, portanto, consiste em recursos interativos pré-programados, permite que a visualização seja manipulada, em certo grau, pelos usuários. Dessa forma, aproximando o conceito visualização narrativa da nossa proposta de análise do dispositivo infovis, gradiente de mediação está para o tratamento da mensagem jornalística com objetivo de narrar fatos ou acontecimentos jornalísticos segundo um ponto de vista assim como gradiente de interatividade está para os recursos interativos de exploração do conteúdo, que concedem aos usuários percursos mais autônomos no consumo informativo.

Para explicar o modo como qualidades narrativas e interativas são reunidas numa mesma visualização, mas com intensidades gradativas, os autores propõem a distinção entre duas abordagens extremas, que podemos transpor para análise comunicacional do dispositivo infovis: abordagem direcionada pelo autor (author-driven) - na qual figuram visualizações com ênfase na mediação sem ou com poucos recursos interativos - e 
abordagem direcionada pelo leitor (reader-driven) que adaptaremos para direcionada pelo usuário - na qual figuram visualizações com ênfase em recursos interativos e sem ou com pouca mediação. As duas abordagens são posicionadas nos extremos de uma linha contínua (Figura 27) na qual visualizações se situam em algum ponto:

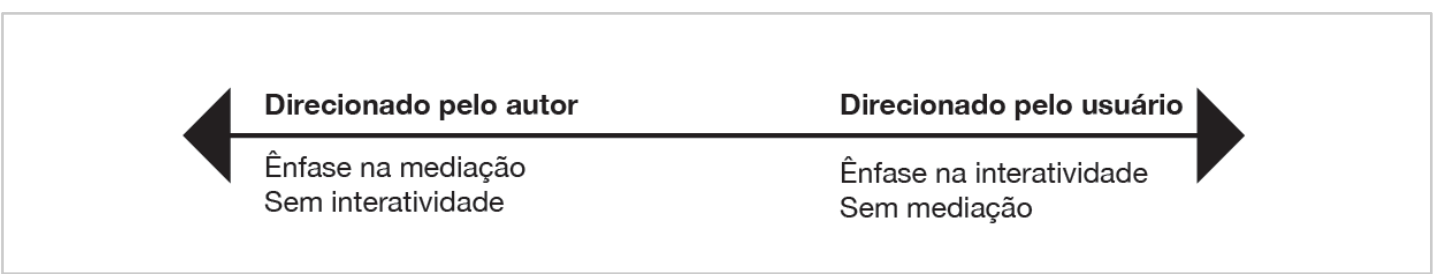

Figura 27 - Abordagens comunicacionais. Fonte: Segel e Heer, 2010.

Abordagens direcionadas pelo autor e pelo usuário refletem, em nossa pesquisa, a percepção de modelos comunicacionais para o dispositivo infovis com ênfases diferentes, mas não excludentes: o modelo comunicacional direcionado pelo autor está para a ênfase na mediação e no tratamento narrativo-jornalístico assim como o modelo comunicacional direcionado pelo usuário está para a ênfase nos recursos interativos de exploração do conteúdo e na narrativa construída também pelo usuário mesmo sabendo que as interações partem de escolhas preestabelecidas pelo polo emissor. Como, na amostra total, a média de gradiente de mediação das peças de todos os veículos comunicativos (Tabela 5, p. 153) tende a ser superior à do gradiente de interatividade, podemos concluir que o modelo comunicacional direcionado pelo autor prevalece no corpus desta pesquisa. No entanto, observando, isoladamente, os gradientes de cada dispositivo infovis, ${ }^{60}$ identificamos peças que fogem a esse padrão, apontando práticas que podem ser consideradas pioneiras na produção infográfica.

O Gráfico 6 apresenta um guia, construído por nós, para interpretar o índice dos gradientes de mediação e de interatividade de cada dispositivo infovis com base nos modelos comunicacionais 'direcionado pelo autor' e 'direcionado pelo leitor':

\footnotetext{
${ }^{60}$ Reiteramos que os valores dos gradientes de mediação e de interatividade de todas as peças podem ser consultados no formulário de análise que encontra-se no Anexo 1, contido em $\mathrm{CD}$, e na web através do endereço $<$ http://goo.gl/bfQac0>.
} 


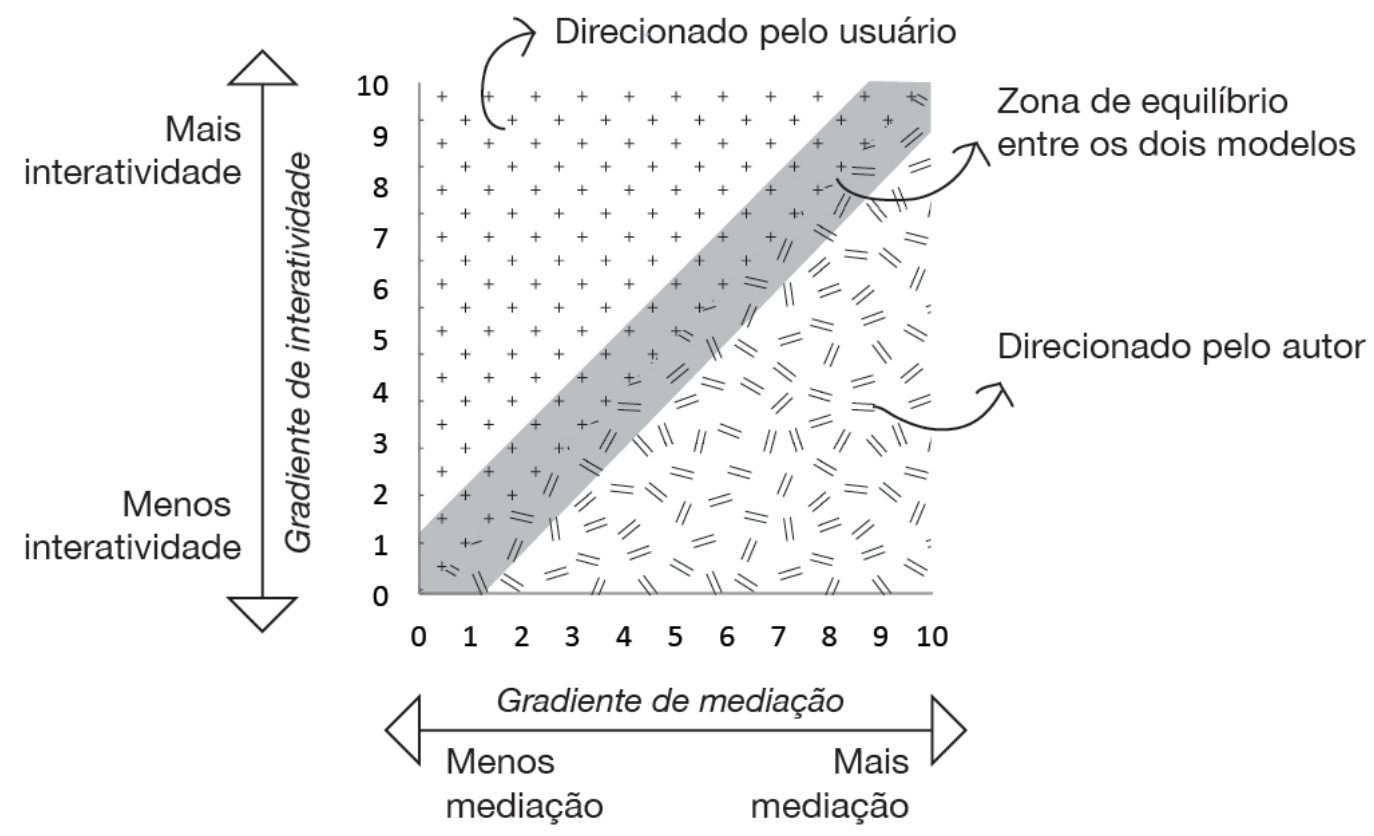

Gráfico 6 - Guia para interpretar o modelo comunicacional do dispositivo infovis. Fonte: elaboração própria.

No Gráfico 6, relacionamos os índices do gradiente de mediação e gradiente de interatividade com três modelos comunicacionais. O modelo direcionado pelo autor, corresponde a peças que apresentam maior índice de mediação jornalística do que interatividade com o conteúdo. O segundo modelo é composto de peças que apresentam equilíbrio entre recursos de tratamento jornalístico e recursos interativos de exploração do conteúdo. Por último, o modelo direcionado pelo usuário é composto de peças com maior ênfase nos recursos interativos de exploração do conteúdo do que nos recursos de tratamento jornalístico. Identificamos, por meio do guia (Gráfico 6), a posição dos gradientes de cada peça constituinte do corpus a fim de verificar ênfases em seus modelos comunicacionais. Destacamos, no entanto, que esse guia não representa metodologia estanque e que certos infovis do corpus se situam em modelos comunicacionais de tênues limites entre si. Dito isso, consideramos que cerca de $75 \%$ do corpus (203 peças) apresenta índices gradativos para ser enquadrado no modelo direcionado pelo autor, enquanto $19 \%$ dele (51 peças) possui pontuações indicativas de equilíbrio entre duas abordagens comunicacionais e apenas $6 \%$ (16 peças) possui gradientes de mediação e de interatividade compatíveis com o modelo direcionado pelo usuário.

Cada um dos três modelos comunicacionais pode ser associado a um dos três tipos de estruturas narrativas propostos por Segel e Heer (2010): 1) estrutura do copo 
de Martini - ênfase na mediação; 2) estrutura de profundidade - ênfase na interatividade e 3) estrutura de slideshow interativo - equilíbrio entre mediação e interatividade. A seguir, apresentamos as estruturas narrativas que caracterizam cada modelo comunicacional exemplificando-as com peças analisadas em nossa pesquisa.

A estrutura copo de Martini (Figura 28) assemelha-se “[...] a uma taça de Martini, cuja haste simboliza o caminho único da abordagem direcionada pelo autor, e cuja boca, alargando-se, representa possíveis percursos interativos da abordagem direcionada pelo usuário" (SEGEL; HEER, 2010). Essa estrutura configura um modelo comunicacional marcado, em sua totalidade, pela mediação comunicativa com base na presença de recursos de tratamento e narrativa jornalísticos, mas com algumas marcas de interatividade por parte do usuário. Constitui a estrutura narrativa mais presente no corpus da pesquisa, representando cerca de $75 \%$ dos infovis.

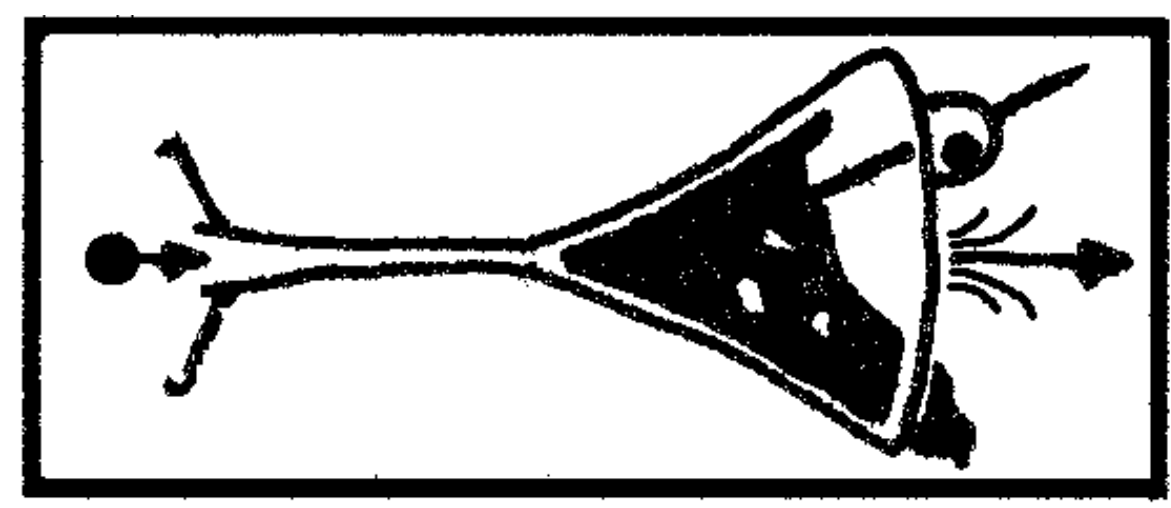

Figura 28 - Estrutura copo de Martini. Fonte: Segel e Heer, 2010.

Corruption index 2010 (TGU_1003) (Figura 29), publicado pelo The Guardian em 26 de outubro de 2010, trata-se de infovis que apresenta níveis de corrupção mundial (evidência quantitativa) distribuídos em um mapa (evidência geográfica) constituindo representação gráfica com características de cartograma (CAIRO, [2013]). Seu gradiente de mediação é de seis pontos, enquanto seu gradiente de interatividade é de um ponto, configurando-se como dispositivo infovis com ênfase no modelo comunicacional direcionado pelo autor. Os recursos de tratamento jornalístico que caracterizam o gradiente de mediação de valor seis e o recurso interativo de exploração do conteúdo que configura o gradiente de interatividade, de valor um, são descritos na Tabela 6. 


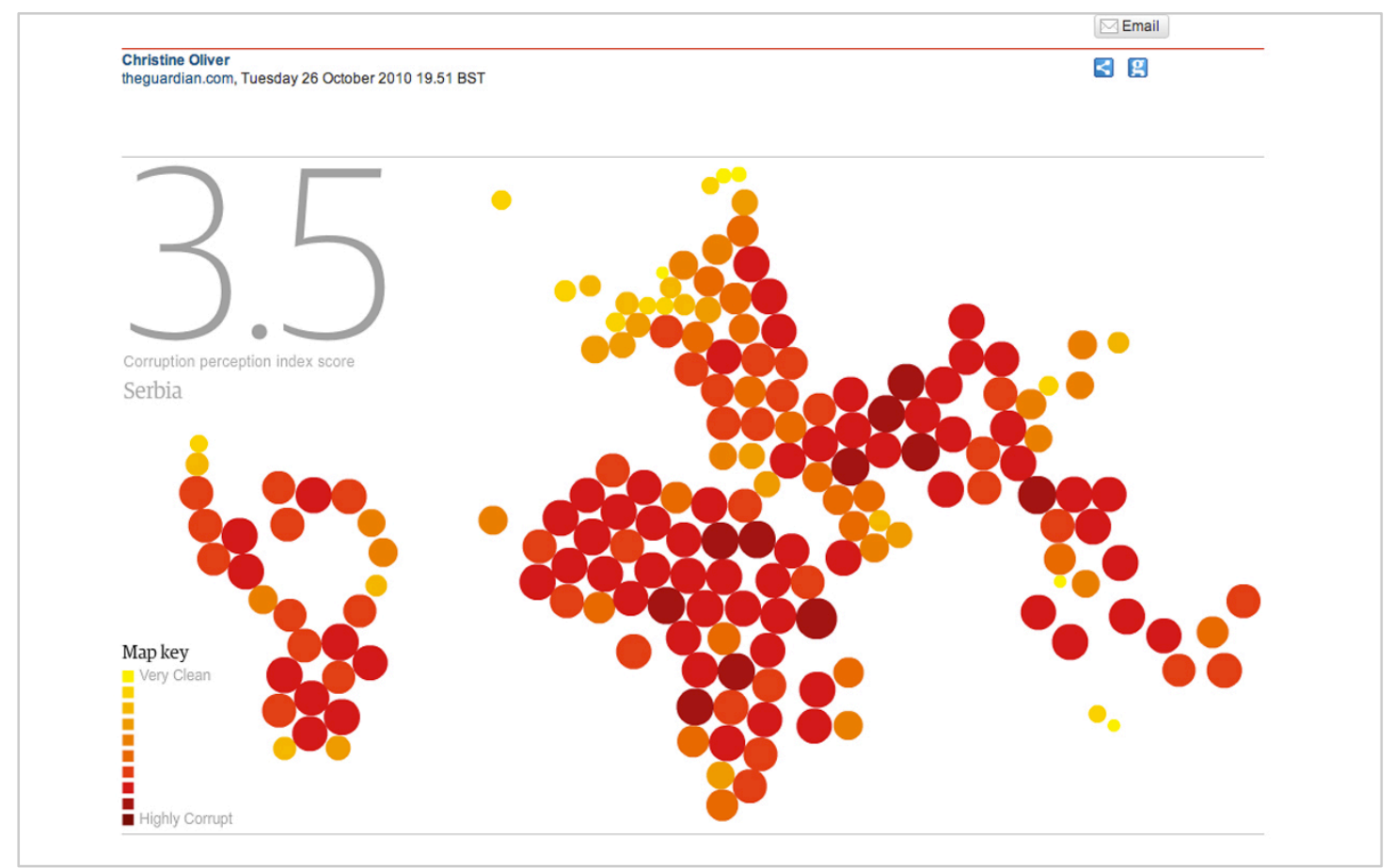

Figura 29 - Corruption index 2010 - Infovis de estrutura de copo de Martini. Fonte: The Guardian, $2010 .^{61}$

Tabela 6 - Codificação dos gradientes de Corruption index 2010

\begin{tabular}{llll}
\hline Gradiente de mediação $^{\mathbf{6}}$ & & Gradiente de interatividade & \\
\hline Título & $1 \mathrm{pt}$ & Avançar/Retroceder & $0 \mathrm{pt}$ \\
Texto explicativo & $2 \mathrm{pts}$ & Roll over & $1 \mathrm{pt}$ \\
Fonte & $1 \mathrm{pt}$ & Zoom & $0 \mathrm{pt}$ \\
Crédito & $1 \mathrm{pt}$ & Filtragem & $0 \mathrm{pt}$ \\
Artigo & $1 \mathrm{pt}$ & Relação & $0 \mathrm{pt}$ \\
Nota & $0 \mathrm{pt}$ & Busca & $0 \mathrm{pt}$ \\
Multimídia & $0 \mathrm{pt}$ & Customização & $0 \mathrm{pt}$ \\
& & Extração & $0 \mathrm{pt}$ \\
& & Outro painel de controle & $0 \mathrm{pt}$ \\
& & Hipertextualidade & $0 \mathrm{pt}$ \\
Total & & & $1 \mathrm{pts}$ \\
\hline
\end{tabular}

Fonte: elaboração própria.

Dentre os recursos de tratamento jornalístico, destacamos o texto explicativo, que fornece “[...] ao leitor toda a explicação necessária para a compreensão do

\footnotetext{
${ }^{61}$ Disponível em: <http://www.theguardian.com/global-development/interactive/2010/oct/26/corruption-index2010-countries-world >. Acesso em: fev. 2014.

${ }^{62}$ Os recursos texto explicativo, nota e multimídia são avaliados em termos de ausência, presença parcial ou presença total.
} 
infográfico" (LETURIA, 1998), e a presença de artigo de acompanhamento, que aprofunda a compreensão dos dados representados.

A estrutura slideshow interativo (Figura 30) é caracterizada por balancear as abordagens 'direcionada pelo autor' e 'direcionada pelo usuário', construindo um modelo comunicacional marcado pelo equilíbrio entre gradientes de mediação e interatividade. Em nossa pesquisa, atribuímos essa estrutura às peças que evidenciam gradientes com valores próximos, como demonstrado no guia de modelos comunicacionais (Gráfico 6). Segel e Heer (2010) denominam a estrutura slideshow interativo pelo fato de ela ser descrita, geralmente, por sequências interligadas de slides que representam diferentes unidades significativas conectadas. Dentro de cada slide, opera a estrutura do copo de Martini, que promove a ênfase comunicativa direcionada pelo autor. No entanto, a estrutura em slides pode permitir uma série de ações interativas com o conteúdo, caracterizando a ênfase direcionado pelo usuário. Em nossa amostra, 19\% das peças são caracterizadas por essa estrutura narrativa.

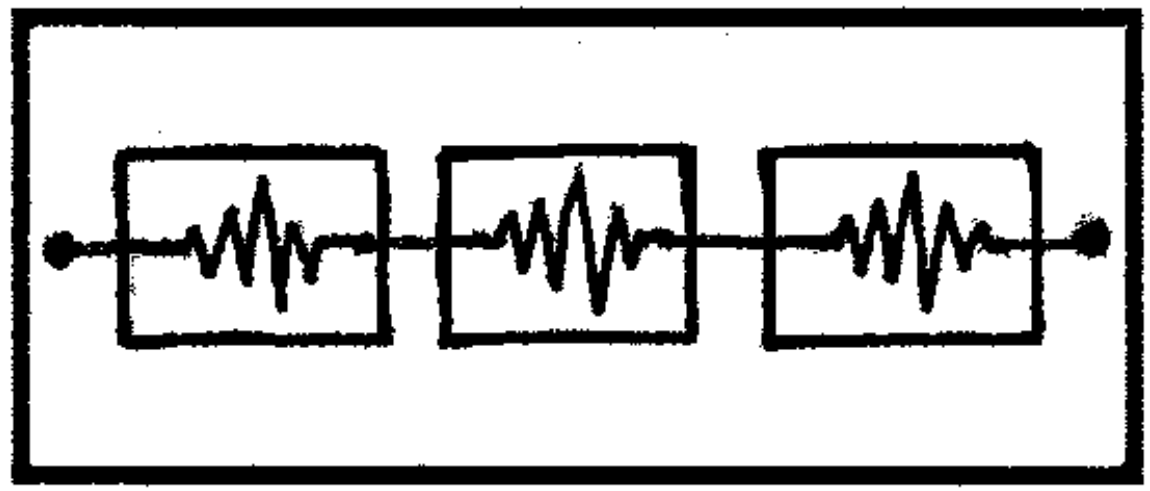

Figura 30 - Estrutura slideshow interativo. Fonte: Segel e Heer, 2010.

A peça The Electoral Map (NYT_1210), já discutida neste capítulo (Figura 23, p. 142), apresenta valor sete para gradiente de mediação e valor seis para gradiente de interatividade, caracterizando-se como dispositivo infovis com equilíbrio entre modelos comunicacionais direcionados pelo autor e pelo usuário. Os recursos de tratamento jornalístico e de exploração do conteúdo, que definem os valores dos gradientes da peça, são apresentados na Tabela 7: 
Tabela 7 - Codificação dos gradientes de The Electoral Map

\begin{tabular}{llll}
\hline Gradiente de mediação & & Gradiente de interatividade & \\
\hline Título & $1 \mathrm{pt}$ & Avançar/Retroceder & $1 \mathrm{pt}$ \\
Texto explicativo & $1 \mathrm{pt}$ & Roll over & $1 \mathrm{pt}$ \\
Fonte & $0 \mathrm{pt}$ & Zoom & $0 \mathrm{pt}$ \\
Crédito & $1 \mathrm{pt}$ & Filtragem & $1 \mathrm{pt}$ \\
Artigo & $0 \mathrm{pt}$ & Relação & $1 \mathrm{pt}$ \\
Nota & $2 \mathrm{pts}$ & Busca & $0 \mathrm{pt}$ \\
Multimídia & $2 \mathrm{pts}$ & Extração & $0 \mathrm{pt}$ \\
& & Customização & $1 \mathrm{pt}$ \\
& & Outro painel de controle & $1 \mathrm{pt}$ \\
& & Hipertextualidade & $0 \mathrm{pt}$ \\
Total & & & $6 \mathrm{pts}$ \\
\hline
\end{tabular}

Fonte: elaboração própria.

Quanto aos recursos de tratamento jornalístico que medeiam, narram e direcionam o usuário para determinada interpretação, destacamos, no infovis The Electoral Map, o uso consistente dos elementos nota e multimídia. A nota textual é utilizada não somente para indicar legendas objetivas, mas, principalmente, para oferecer textos explanatórios e comentários de especialistas que, nessa peça, analisam sete possíveis cenários de vitória (indicados em um menu de botões numéricos) para candidatos presidenciáveis nas eleições de 2012 nos Estados Unidos. Elementos multimídia complementam informações visualizadas no corpo principal do infovis e são compostos de ilustrações dos estados norte-americanos, animações de transição e outras formas gráficas. Quanto aos recursos interativos de exploração do conteúdo, que possibilitam comunicação mais direcionada pelo usuário, destacamos, primeiramente, a opção de navegação avançar/retroceder, por meio de botões representados por setas, que caracteriza estrutura do slideshow interativo. No entanto, a navegação pelos slides também pode ser realizada não linearmente, por meio de botões numéricos, que codificamos como recurso outro painel de controle. Os recursos filtragem, relação e customização representam tarefas interativas interligadas na camada informativa do infovis chamada de Make Your Own Scenarios (Monte seu próprio cenário) e determinam ênfase comunicacional direcionada pelo usuário nessa peça. Filtragem permite que usuários manipulem itens (no caso, os itens são estados 
norte-americanos representados por círculos) que desejam visualizar ou deixar de visualizar em determinado local da interface do infovis. O recurso relação ocorre por meio do processo de filtragem, pois, ao controlar a disponibilização dos itens, os usuários relacionam duas variáveis informativas, candidato e vitória por estado eleitoral, o que lhes permite explorar, com certa autonomia, possíveis caminhos de êxito para candidato às eleições. Por último, customização (PALACIOS, 2003; RODRIGUES, 2009) se faz presente à medida que usuários filtram e relacionam elementos visualizados, gerando novas configurações visuais para o infovis.

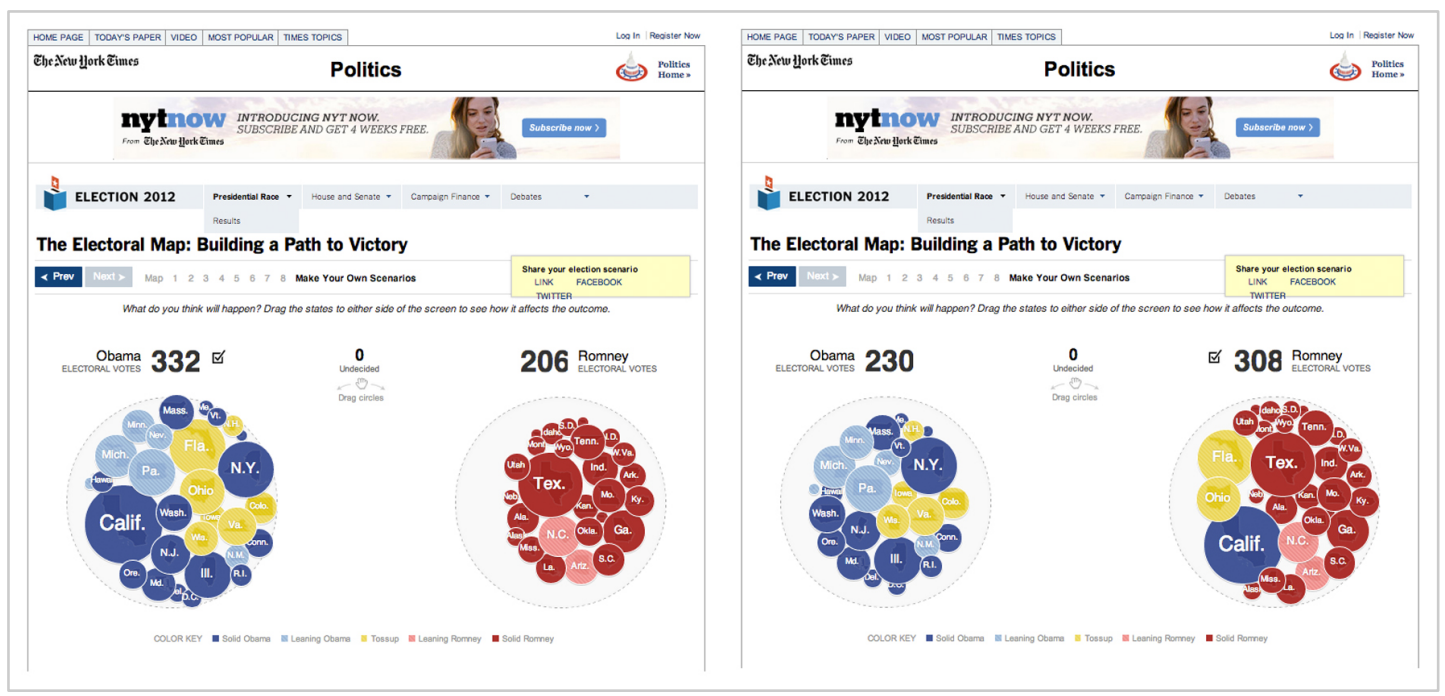

Figura 31 - Diferentes configurações visuais para The Electoral Map Fonte: The New York Times, $2012 .^{63}$

A Figura 31 ilustra duas possíveis configurações visuais do infovis que representam, semanticamente, cenários políticos opostos: no frame à esquerda, a distribuição dos itens (estados norte-americanos representados por círculos coloridos) - sobretudo os em amarelo, que indicam estados indecisos em pesquisas eleitorais decide o resultado das eleições a favor do candidato democrata Barack Obama em um placar de 332 votos contra 206; já no frame à direita, uma inesperada, mas possível mudança no cenário político, desloca o estado da Califórnia, tendencialmente democrata e com sólida força eleitoral, para o partido republicano. Junta-se a esse cenário uma possível vitória de Mitt Romney em estados indecisos, como Florida e Ohio, e a vitória geral é do partido republicano, em um placar de 308 votos contra 230. Ao final da distribuição de todos os estados, e suas respectivas cadeiras

\footnotetext{
${ }^{63}$ Disponível em: <http://elections.nytimes.com/2012/ratings/electoral-map >. Acesso em: fev. 2013.
} 
eleitorais, por preferência partidária, usuários visualizam possíveis resultados eleitorais que eles mesmos projetaram, amparados, ou não, por notas explicativas e comentários do infovis, que apontam preferência partidária previsível para cada estado norte-americano. Os usuários, finalmente, podem compartilhar suas previsões eleitorais nas redes sociais. Consideramos que esta última atividade extrapola a qualidade de interatividade usuário/conteúdo, para tornar-se ação interativa participativa do tipo conteúdo/conteúdo, tópico que será abordado na seção 4.3.2 do presente capítulo.

A estrutura de profundidade (Figura 32) apresenta “[...] um tema geral e então permite que usuários interajam com determinadas instâncias [do conteúdo] para revelar detalhes adicionais e informações contextuais" (SEGEL; HEER, 2010). Essa estrutura representa modelos comunicacionais mais sinalizados pela exploração do conteúdo direcionada pelo usuário e apresenta menos recursos de mediação jornalística e direcionamento do autor. A estrutura de profundidade caracteriza, portanto, peças que obtiveram maior gradiente de interatividade e menor gradiente de mediação. Constitui a estrutura narrativa menos presente no corpus da pesquisa, representando cerca de $6 \%$ dos infovis.

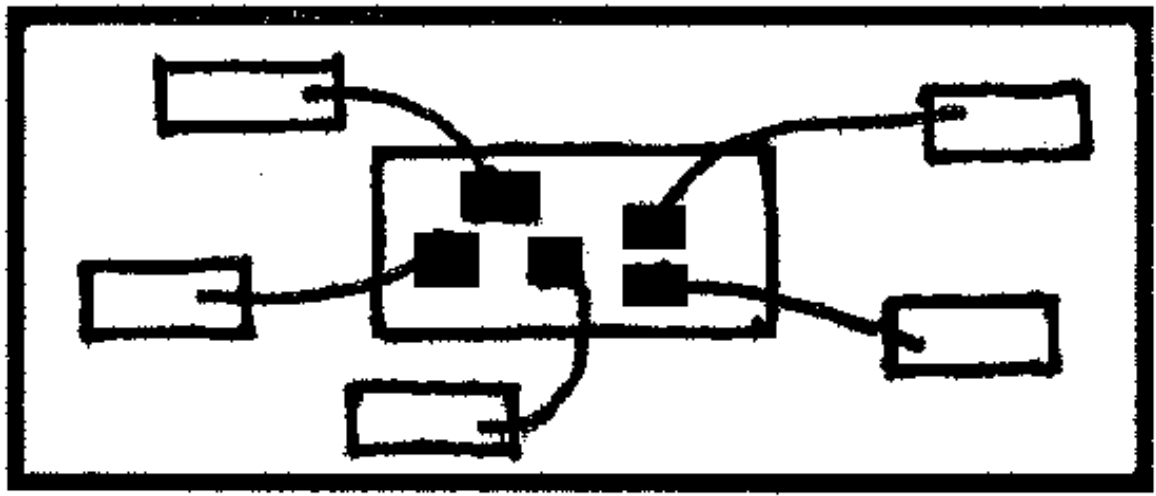

Figura 32 - Estrutura de profundidade. Fonte: Segel e Heer, 2010.

Basômetro (ESP_1337) (Figura 33), publicado por O Estado de S. Paulo em 2013, é atualizado frequentemente pela seção Estadão Dados; trata-se de infovis que "mede" - evidência quantitativa -, segundo escala criada pela publicação, apoio ao governo por parte dos parlamentares agrupados por partido e acompanha seus posicionamentos favoráveis ou desfavoráveis ao governo ao longo das votações legislativas - evidência temporal. Cada parlamentar é representado por um círculo 
cuja cor indica o partido ao qual ele pertence. Quanto mais próximo da zona superior do plano o círculo está maior é a taxa de governismo, isto é, postura favorável às decisões do governo do parlamentar representado.

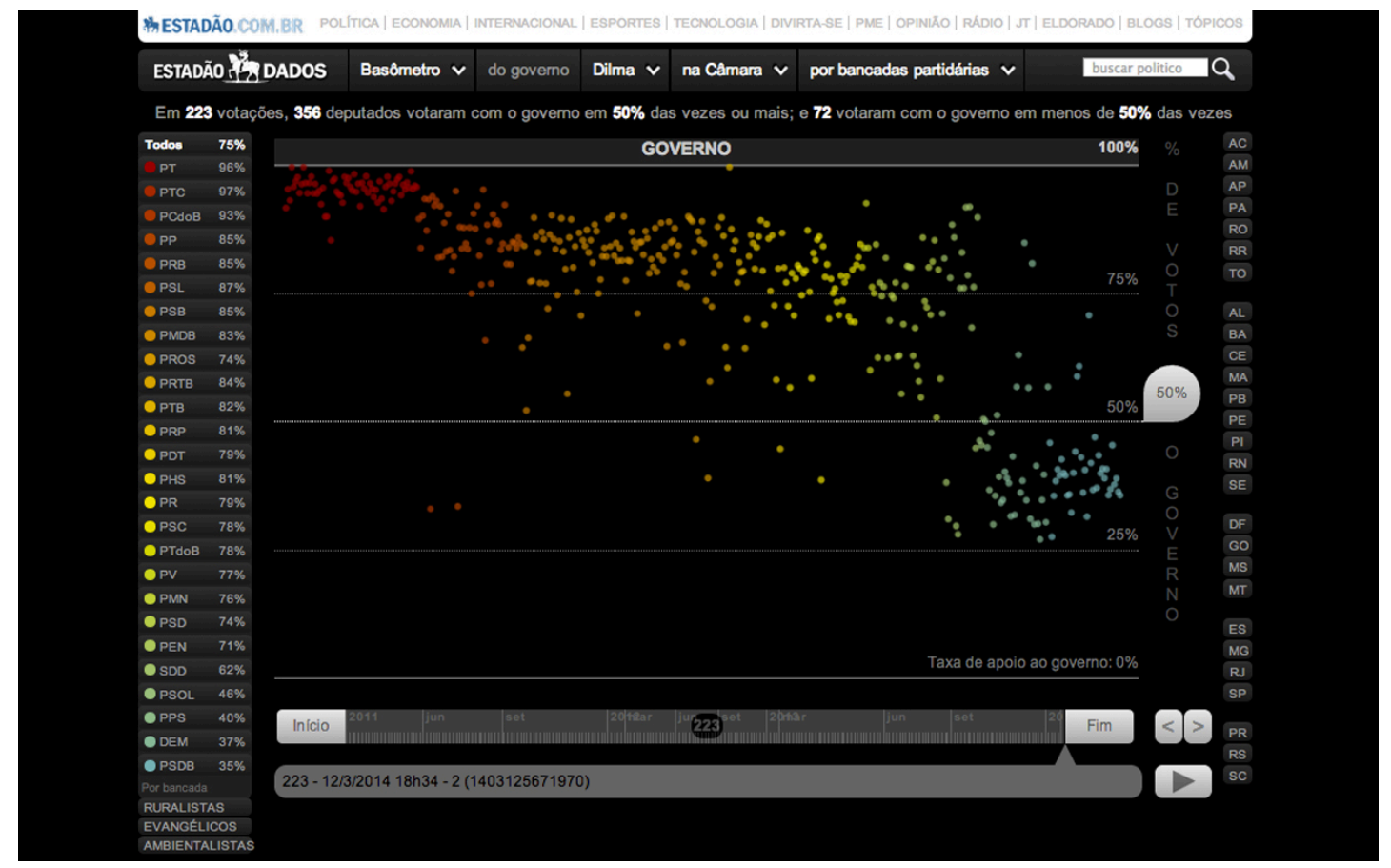

Figura 33 - Basômetro - Infovis de estrutura de profundidade. Fonte: O Estado de S. Paulo, 2013. ${ }^{64}$

Os gradientes de mediação e de interatividade da presente peça são seis e oito pontos, respectivamente, configurando-a como dispositivo infovis com ênfase no modelo comunicacional direcionado pelo usuário. Recursos de tratamento jornalístico, que caracterizam o gradiente de mediação de valor seis, e recursos interativos de exploração do conteúdo, que configuram o gradiente de interatividade de valor oito, são descritos na Tabela 8:

Tabela 8 - Codificação dos gradientes do Basômetro

\begin{tabular}{lclc}
\hline Gradiente de Mediação & & Gradiente de Interatividade \\
\hline Título & $0 \mathrm{pt}$ & Avançar/Retroceder & $1 \mathrm{pt}$ \\
Texto explicativo & $1 \mathrm{pt}$ & Roll over & $1 \mathrm{pt}$ \\
Fonte & $1 \mathrm{pt}$ & Zoom & $0 \mathrm{pt}$ \\
Crédito & $1 \mathrm{pt}$ & Filtragem & $1 \mathrm{pt}$ \\
Artigo & $1 \mathrm{pt}$ & Relação & $1 \mathrm{pt}$
\end{tabular}

\footnotetext{
${ }^{64}$ Disponível em: <http://estadaodados.com/basometro>. Acesso em Jan. 2014.
} 


\begin{tabular}{lllr} 
Nota & 0pt & Busca & $1 \mathrm{pt}$ \\
Multimídia & $2 \mathrm{pts}$ & Extração & $1 \mathrm{pt}$ \\
& & Customização & $1 \mathrm{pt}$ \\
& & Outro painel de controle & $1 \mathrm{pt}$ \\
& & Hipertextualidade & $0 \mathrm{pt}$ \\
Total & & & $8 \mathrm{pts}$ \\
\hline
\end{tabular}

Fonte: elaboração própria.

Embora gradientes de mediação e de interatividade sejam bastante próximos - o que dificulta a identificação precisa do modelo comunicacional desse dispositivo -, percebemos ênfase na abordagem direcionado pelo usuário, pois, à medida que os infovis alcançam maiores graus de interatividade, recursos interativos de exploração com conteúdo sobressaem-se frente aos recursos de tratamento jornalístico. Dito isso, destacamos alguns recursos presentes nessa peça que caracterizam seu alto gradiente de interatividade. A customização é percebida pela possibilidade de adaptar a configuração visual do infovis segundo preferências estabelecidas pelo dispositivo (RODRIGUES, 2010): usuários podem visualizar a taxa de governismo dos parlamentares por bancadas partidárias ou por votações (opção apresentada na parte superior à direita da interface). Em qualquer momento, usuários podem utilizar o recurso roll over sobre os círculos que representam parlamentares, visualizando, dessa forma, informações detalhadas a seu respeito. O recurso busca permite que usuários procurem diretamente, por meio da digitação do nome ou sobrenome, parlamentares específicos e visualizem suas taxas de governismo. A sequência de votações é percebida por barra de controle deslizável que manuseia o tempo (de 2011 até o momento) e que classificamos como recurso outro painel de controle. Parlamentares podem ser filtrados por partido e estado (opções apresentadas nas laterais da interface), e essas duas variáveis informativas são relacionadas na apresentação de taxa de governismo no infovis. Por último, comentamos o recurso extração, pois ele merece atenção particular não só nessa peça, mas na análise do corpus em geral. O recurso de extração - que possibilita download parcial ou total dos dados representados em determinado infovis está presente de modo indireto na peça Basômetro. A página do infovis disponibiliza acesso aos dados brutos oriundos de fontes oficiais do governo foram organizados e editados em planilhas do Google Docs. Essas planilhas, por sua vez, permitem extração 
dos dados brutos. Basômetro representa, em nossa amostra, dispositivo infovis inovador, e seu pioneirismo reflete-se na maneira como lida com dados da esfera política e pública, cruzando-os, atualizando-os continuadamente e permitindo suas extrações.

\subsubsection{Extração de dados}

No corpus da pesquisa, o recurso de extração dos dados está presente em apenas 24 peças (9\%), ${ }^{65} 14$ delas do The Guardian e seis de O Estado de S. Paulo. Mas o que, de fato, representa esse recurso interativo em termos comunicacionais?

Extração de dados pode ser associada à prática open data, movimento que apoia a transparência de determinados dados, da esfera pública ou privada, defendendo sua disponibilização ao público, de maneira acessível e gratuita, para que possam ser livremente circulados e reutilizados para diversos fins. Essa tendência tem-se consolidado com a difusão da internet e com o surgimento de inúmeras organizações, iniciativas e manuais, brasileiros e estrangeiros, ${ }^{66}$ a favor da causa. No Brasil, a Constituição garante, pela Lei de Acesso à Informação, o direito de se requisitar informação de interesse público ao Estado e estabelece para os agentes públicos o dever de disponibilizar seus atos (ABRAMO, 2013). No entanto, o fato de a lei ter sido implementada recentemente, em 2012, e ter permitido aos órgãos públicos a prerrogativa de gozar do direito à informação sigilosa, institui espaço para a legitimidade das fontes oficiais do governo ser questionada. Por esses fatores, vemos o surgimento de ferramentas independentes e on-line para distribuição e compartilhamento de dados, como os sítios The Data Hub, ScraperWiki e o Freebase, e outros mecanismos autônomos, como fóruns e listas de e-mails, que utilizam a inteligência coletiva da rede.

O movimento open data vai ao encontro da premissa defendida pelo jornalismo político de proporcionar aos cidadãos informações que lhes permitam

\footnotetext{
${ }^{65}$ As peças são: TGU_1301, TGU_1302, TGU_1304, TGU_1305, TGU_1309, TGU_1310, TGU_1316, TGU_1201, TGU_1202, TGU_1206, TGU_1207, TGU_1210, TGU_1214, TGU_1102, TGU_1106, TGU_1002, TGU_1005, TGU_1008, ESP_1301, ESP_1306, ESP_1307, ESP_1337, ESP_1210, ESP_1211.

${ }_{66}$ Para citar alguns exemplos nacionais e estrangeiros: Portal da Transparência do Governo Federal (<http://www.portaldatransparencia.gov.br>), Transparência Brasil (<http://www.transparencia. org.br/>) Páginas da Transparência Pública (<http://www3.transparencia.gov.br/TransparenciaPublica >), The Open Knowledge Foundation (<http://okfn.org $>$ ), The Open Data Handbook (<http://opendatahandbook.org $>)$, U.S. Government's open data (<http://data.gov $>)$, Opening up Government ( $<$ http://data.gov.uk $>)$.
} 
fazer parte da democracia deliberativa (MCNAIR, 2009, p. 239) e, atualmente, pode ser percebido dentro de organizações jornalísticas com a criação e consolidação de seções $^{67}$ voltadas especificamente para discussão e produção de conteúdos com os códigos abertos. A transparência e abertura dos dados, amplamente defendida quando de origem público-governamental, parece expandir-se, também, para algumas empresas de comunicação jornalística, como The Guardian e O Estado de S. Paulo, que utilizam o recurso de extração de dados, em seus infovis, de modo mais deliberado do que The New York Times e Folha de S. Paulo.

$\mathrm{Na}$ etapa de circulação do produto midiático, o recurso extração permite novos usos para dados representados em infovis, como “[...] enviar por e-mail, imprimir, criar o gráfico novamente, ou inserir em outro conjunto de dados" (SHNEIDERMAN, 1996, p. 5), o que interfere nas fronteiras entre produtores e usuários do processo comunicacional. A aproximação entre esses dois interagentes, na produção e consumo do dispositivo infovis, permite-nos incorporar o conceito de produser (BRUNS, 2008), isto é, justaposição dos papeis de produtor (prod) e usuário (user) da informação, ao polo receptor. Extrair significa desconstruir o infovis e retornar a seu estado bruto, isto é, à base de dados. Em tempos de crise de legitimidade, o Jornalismo pode buscar, na transparência do código, um selo de compromisso com a origem da fonte e, logo, um dever com a "verdade" e com a imparcialidade. Paralelamente, a extração pode significar a estratégia legitimadora disfarçada em discurso jornalístico que se mantém, internamente, amarrado às lógicas midiáticas orquestradas pelos critérios de noticiabilidade e agendamento. Com as devidas ressalvas, o recurso de extração representa, potencialmente, processos de apropriação e ressignificação do conteúdo, uma vez que faculta download dos dados e suas reutilizações para outros fins.

Gay Marriage bill: how did your MP vote? (TGU_1316) (Figura 34) exemplifica, de modo profícuo, o recurso interativo para extração de dados do infovis e as novas possibilidades de consumo informativo que o código aberto permite ao usuário. A peça, publicada pela seção Datablog, em 6 de fevereiro de 2013, permite visualizar como membros do parlamento do Reino Unido votaram (a favor ou

\footnotetext{
${ }^{67}$ Seções dos veículos jornalísticos estudados nesta pesquisa: Data Store (<http://www.guardian.co.uk/ data $>$ ), Datablog (<http://www.theguardian.com/news/datablog $>$ ), Open (<http://open.blogs.nytimes.com>), FolhaSPDados (<http://folhaspdados.blogfolha.uol.com.br $>$ ), Afinal de Contas (<http://afinaldecontas.blogfolha.uol.com.br $>$ ) e Estadão Dados (<http://blog.estadaodados.com $>$ ).
} 
contra), por distrito eleitoral e partido, no projeto de lei para legalizar o casamento gay no país. É disponibilizado, ao usuário, acesso aos dados brutos, bem como sua extração por meio de planilha Google Docs.

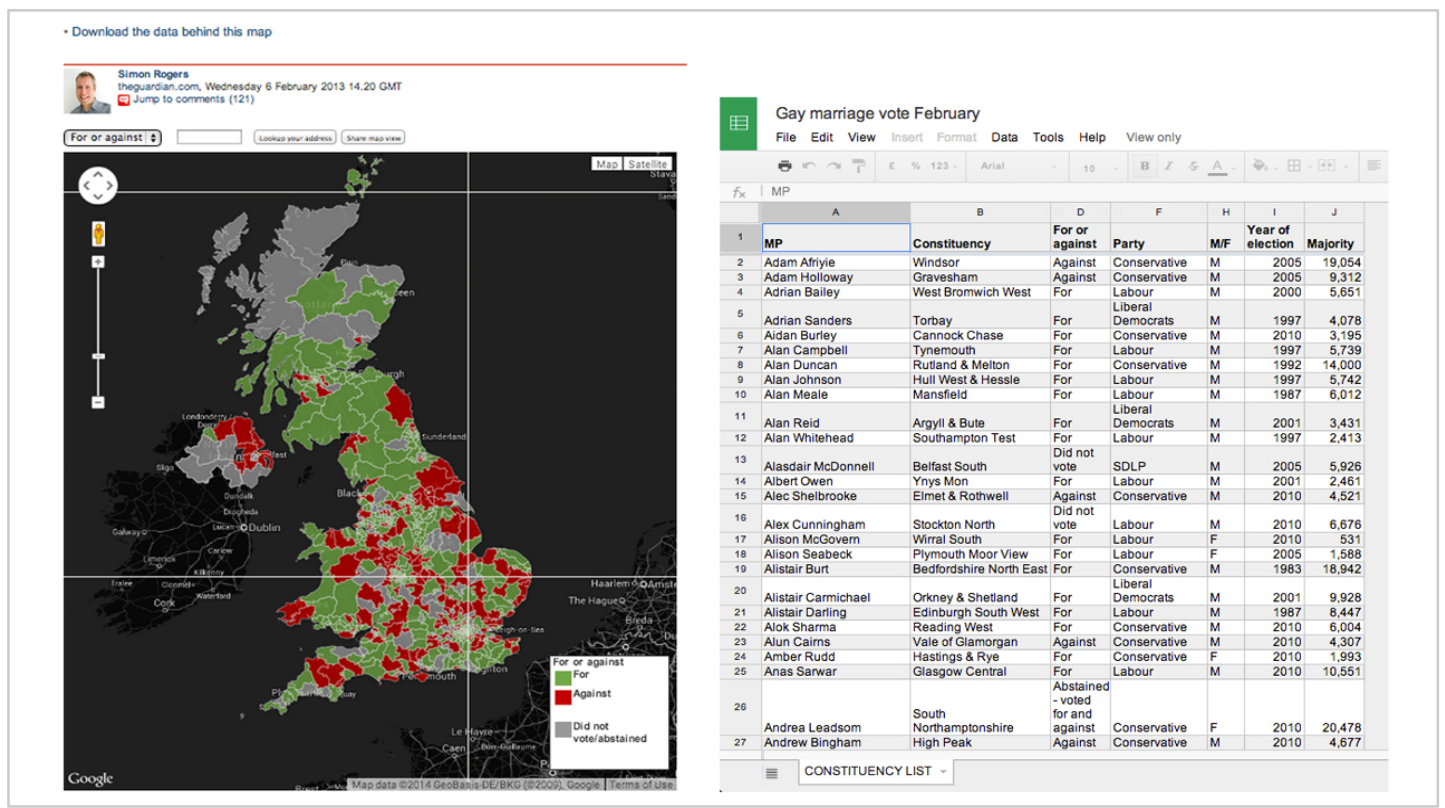

Figura 34 - Gay Marriage bill: how did your MP vote? - Infovis de código aberto. Fonte: The Guardian, 2013. ${ }^{68}$

Em nossa pesquisa, a análise da subunidade extração identifica se infovis permitem, ou não, download total ou parcial de dados. Não verificamos, peça a peça, se esse recurso interativo possibilita novas apropriações comunicativas aos conjuntos de dados extraídos. No entanto, a seção Datablog, do veículo comunicativo The Guardian chama nossa atenção pelo fato de promover, paralelamente a disponibilização dos dados para download, o incentivo para que usuários os ressignifiquem, criando novas representações visuais que podem ser compartilhadas na rede social Flickr ${ }^{69}$ especificamente em conta criada pela publicação para reunir contribuições de usuários colaboradores.

Identificamos uma nova representação visual não interativa (Figura 35), criada, a partir dos dados extraídos da peça Gay Marriage bill: how did your MP vote? (Figura 34), por um usuário comum e compartilhada na página Flickr da seção

\footnotetext{
${ }^{68}$ Disponível em: <http://www.theguardian.com/news/datablog/interactive/2013/feb/06/gay-marriage-vote-mapmp>. Acesso em dez. 2013.

${ }^{69}$ A página do Flickr chama-se Guardian DataStore: take our data, mash it up and create great visualizations with it. Then post them on here. Disponível em: <https://www.flickr.com/groups/1115946@N24>. Acesso em out. 2013.
} 
Datablog. O resultado final apresenta nova organização visual que realça determinados dados não evidenciados na versão original, como, por exemplo, números exatos de votos a favor e contra o projeto de lei, agrupados por partido.

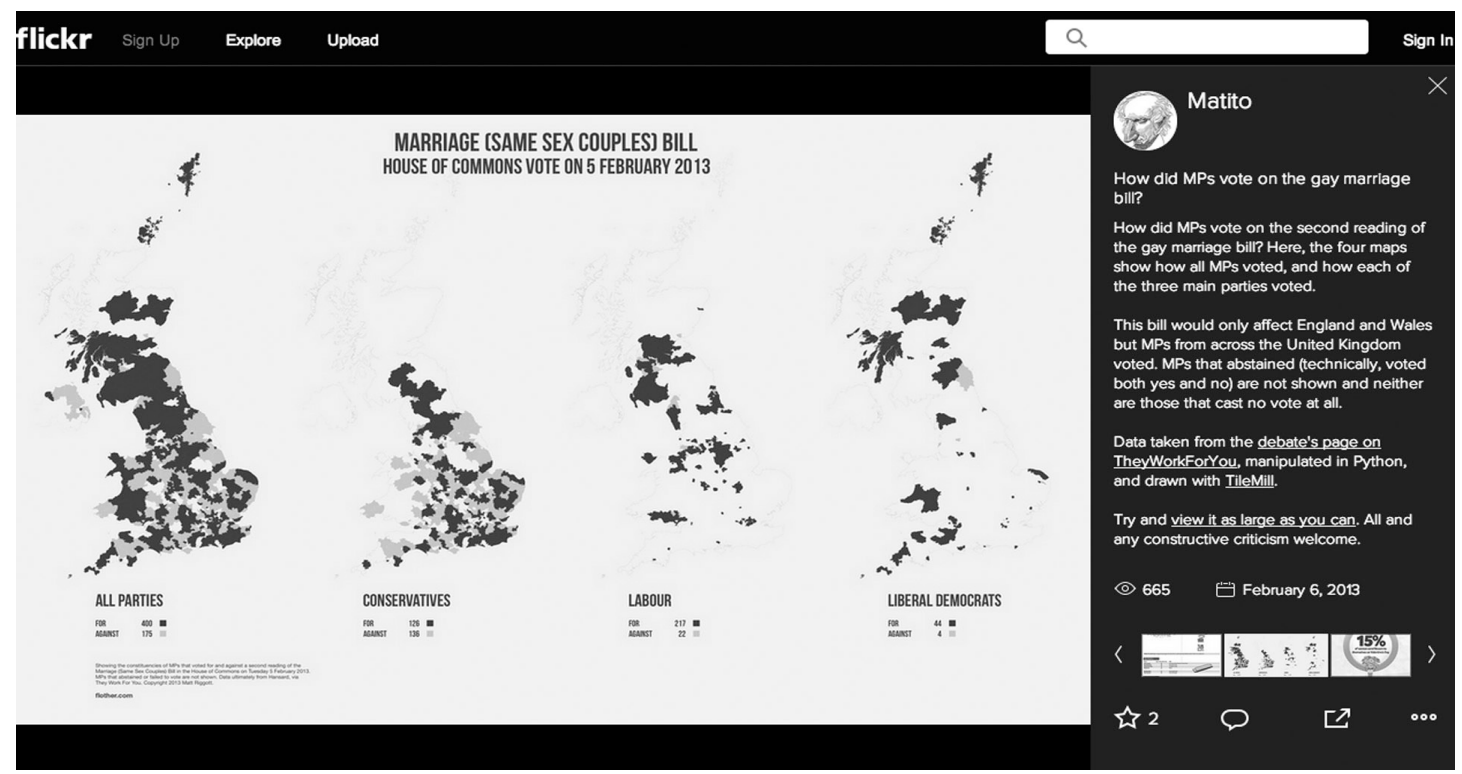

Figura 35 - Flickr da seção Datablog - Ressignificação dos dados extraídos. Fonte: Flickr, 2013. ${ }^{70}$

Afinal, existiria fórmula ideal para equilibrar gradiente de mediação jornalística e gradiente de interatividade com conteúdo, em um mesmo dispositivo infovis? Do ponto de vista produtivo, seria melhor apresentar dados e contá-los sob determinada perspectiva - como prevê, tradicionalmente, o gênero jornalístico informativo - ou permitir, aos usuários, manipulação mais autônoma dos dados visualizados à medida que formulam suas perguntas e buscam respostas, estabelecendo um processo de produção de conhecimento mais individual e menos mediado? Essas são perguntas atuais que abrangem a realidade da produção infográfica, assim como o exercício jornalístico em sua totalidade, e suscitam posicionamentos divergentes entre especialistas e pesquisadores da área. Amanda Cox, editora do departamento de infografia do The New York Times, em entrevista ao sítio Simply Statistics, defende a necessidade do papel da mediação de jornalistas e designers na edição dos dados de um infográfico, destacando aquilo que é relevante do que é trivial, para uma comunicação jornalística efetiva:

Eu também acho que palavras, em um infográfico, deveriam destacar padrões percebidos no conjunto de dados ou

\footnotetext{
${ }^{70}$ Disponível em: <https://www.flickr.com/photos/riggott/8450628843/in/pool-guardiandatastore>. Acesso em out. 2013.
} 
intepretações de especialistas sobre o conteúdo, e não apenas representar dados brutos para que usuários busquem alguma significação a respeito deles. A camada de notas é fundamental [em infográficos], ainda que se tratando de conteúdo jornalístico, no qual dados, geralmente, não são muito complicados (COX, 2012).

Paralelamente, o editor da seção Estadão de Dados, José Roberto Toledo, afirma, durante seminário ${ }^{71}$ sobre o lançamento do Basômetro, projeto de que é também idealizador, que este não foi concebido como matéria nem como infográfico, mas sim como ferramenta. Avançando sobre possíveis repercussões que a abordagem instrumental sobre o dispositivo infovis pode suscitar não só para sua produção, mas também para outros produtos midiáticos, o autor acrescenta que “[...] a grande diferença é que nós, enquanto jornalistas, estamos abrindo mão do poder de ser o narrador da história e transferindo esse poder para o usuário" (TOLEDO, 2013). Na mesma linha de pensamento, Cairo considera que, na nova conjuntura produtiva, “[...] o jornalista visual deixa de ser quem interpreta os dados para leitores, para converter-se, de certa maneira, no indivíduo que desenha as ferramentas para que leitores possam as usar para desvendar a realidade por si mesmos" (CAIRO, 2008, p. 68, grifo original). Um fato concreto que parece ilustrar os discursos de Toledo (2013) e Cairo (2008) foi noticiado pela revista americana The Atlantic, em janeiro de 2014, com a seguinte chamada: A matéria mais popular do The New York Times em 2013 não foi uma notícia. ${ }^{72}$ A notícia aponta que, entre as dez matérias mais visitadas do sítio The New York Times, em 2013, figura, em primeiro lugar, uma história que não pode ser classificada entre os gênero jornalísticos tradicionais. How Y'all, Youse, and You Guys $T_{a l k}^{73}$ não é notícia, reportagem, nem entrevista, pelo menos não em seus formatos usuais. O produto midiático é, como aponta a revista The Atlantic, um news app, uma notícia em formato de aplicativo, que desenvolve um jogo sobre diferentes sotaques pronunciados nos Estados Unidos, com o qual o usuário deve interagir. Como destaca a revista, o mais surpreendente é que o news app, publicado em 21 de dezembro de 2013,

\footnotetext{
${ }^{71}$ Seminário realizado no Cepesp (Centro de Política e Economia do Setor Público) em agosto de 2013 e disponível nos hyperlinks: <http://www.youtube.com/watch?v=Bv0JMoAG17U\&feature=youtu.be $>$ e <http://www.youtube. com/watch?v=e-efOyTJEow\&feature=youtu.be $>$. Acesso em out. 2013.

72 The New York Times' most popular story of 2013 was not an article. Disponível em <http://www.theatlantic. com/technology/archive/2014/01/-em-the-new-york-times-em-most-popular-story-of-2013-was-not-anarticle/ 283167/?>. Acesso em jan. 2014.

73 Disponível em: <http://www.nytimes.com/interactive/2013/12/20/sunday-review/dialect-quiz-map.html>. Acesso em jan. 2014.
} 
obteve, em apenas 11 dias de circulação no ano da pesquisa, mais visitas do que qualquer outra matéria do The New York Times, naquele ano. Sobre a utilização de apps no Jornalismo, Nicholas Carr (2011) preconiza:

Hoje, como resultado da computação em nuvem e de outros avanços, os apps se parecem muito com produtos midiáticos. Eles são sustentados por publicidade, aceitam assinaturas, são atualizados constantemente e o conteúdo que disponibilizam é tão importante quanto sua funcionalidade. [...] Oferecem não apenas conteúdo original, mas também um conjunto de ferramentas e funcionalidades online que permitem aos consumidores ver, manipular e ampliar tais conteúdos numa miríade de possibilidades (CARR, 2011, apud SAAD CORREAA; BERTOCCHI, 2012, p. 134-135).

Conjugados os discursos de Toledo (2013) e Cairo (2008) sobre a ampliação do poder do usuário no processo comunicacional e a appficação do conteúdo destacada pela revista The Atlantic apontam cenários, para o Jornalismo e para infografia, extremamente pioneiros e sintonizados com lógicas contemporâneas de comunicação, marcadas pela ubiquidade dos dispositivos móveis, a convergência entre mídias tradicionais, descentralização do emissor, automatização de sistemas de coleta e publicação de informações e potencialidade dos recursos visuais e interativos oferecidos pelas interfaces. Se, por um lado, não preconizamos, de modo algum, o fim da mediação de jornalistas e designers em narrativas e conteúdos informativos, por outro lado, percebemos um movimento complementar, marcado pelo maior grau de autonomia que cada usuário tem de participar de seus percursos comunicacionais e buscar compreensões, apropriações e ressignificações por meio da interface visual-interativa do dispositivo. Em uma realidade na qual jornalistas, ativistas e pesquisadores de Jornalismo demonstram cada vez mais preocupação com a monopolização informativa dos grande conglomerados de comunicação e vinculação noticiosa a interesses econômicos, “[...] novas mídias parecem representar possibilidades para que o jornalismo exerça sua função pública de informar o cidadão para que 'seja livre e capaz de se autogovernar', conforme afirmam Kovach e Rosenstiel [...]” (SCHWINGEL, 2012, p. 13). Nesse sentido, inferimos que lógicas contemporâneas de comunicação estimulam a ampliação de modelos comunicacionais mais direcionados pelos usuários, nos quais os papéis de autor e usuário da informação tangenciam-se por meio das funcionalidades interativas e novas práticas de produção e consumo de infovis delineiam-se. 


\subsubsection{Conteúdo gerado pelo usuário}

Os dados da Tabela 4 (p. 151) demonstram a atividade de compartilhamento que se caracteriza pela capacidade dos usuários de difundir infovis para outros usuários por e-mail ou pelas mídias sociais - configurada como ação participativa amplamente presente na amostra, precisamente em 252 peças (93\% da amostra total). Já a ação de comentário - que permite ao usuário tornar-se emissor de opiniões, sugestões, críticas e discussões, concretizando diálogo com outros usuários ou com os produtores do conteúdo - está presente em 62 peças ( $23 \%$ da amostra total). O veículo comunicativo que mais evidencia ação de comentários em infovis é O Estado de S. Paulo (38\% de suas peças apresentam essa qualidade), enquanto The New York Times é a publicação com menos incidência de comentários em infovis (apenas 2\% de suas peças a possuem). Todos os infovis que apresentam comentário também possuem qualidades participativas de compartilhamento. Dessa forma, concluímos que 93\% da amostra atinge nível conversacional de interatividade (SALAVERRÍA, 2005), isto é, interatividade de tipo usuário/usuário e/ou usuário/jornalista. O Gráfico 7 demonstra o padrão de ações participativas por veículo comunicativo.

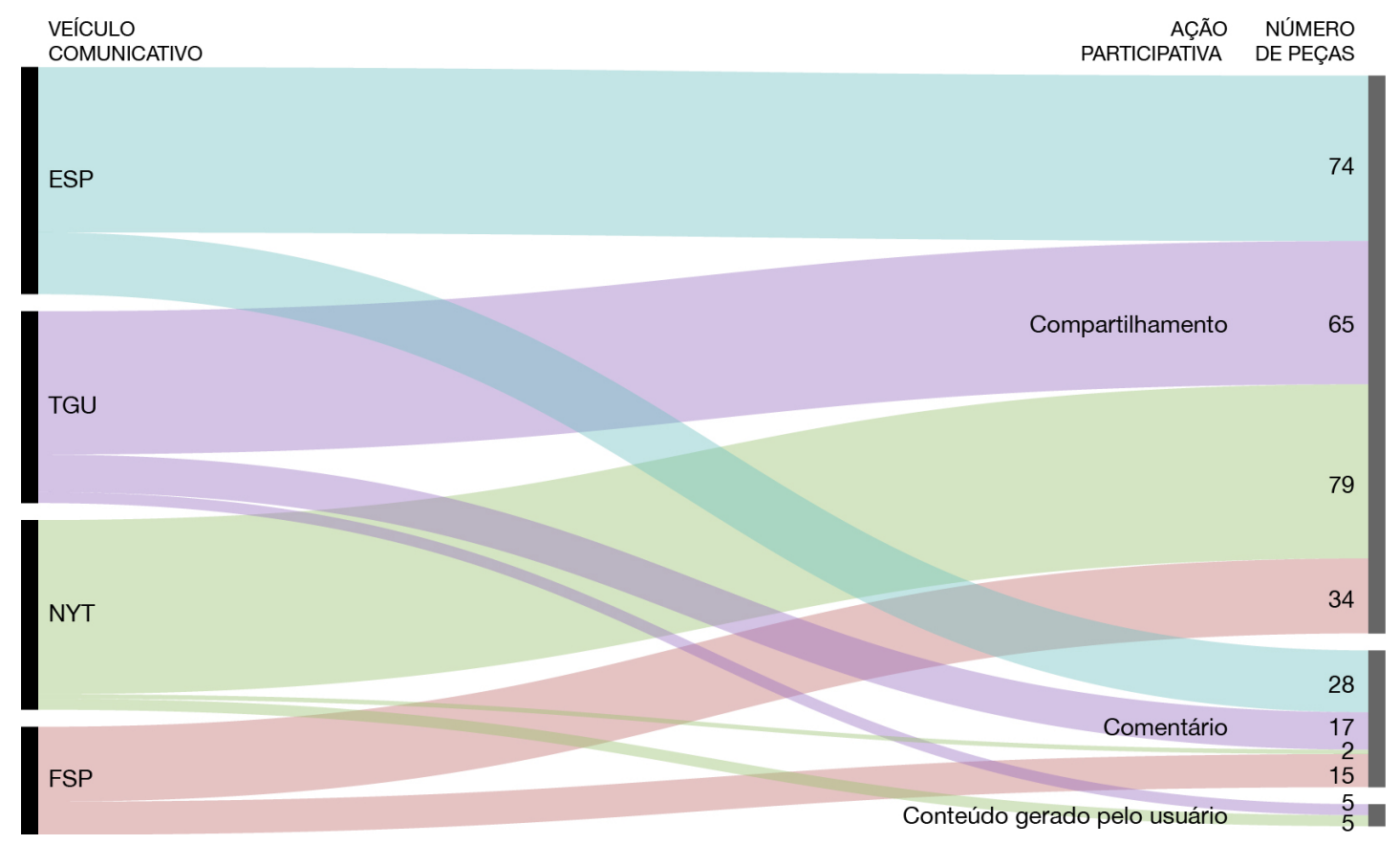

Gráfico 7 - Distribuição de infovis por veículo comunicativo e por ação participativa. Fonte: elaboração própria utilizando a ferramenta Raw. 
Entretanto, ações participativas de nível conversacional, embora proporcionadas pelo suporte de circulação on-line e importantes aspectos comunicacionais, não significam diretamente transformações na etapa de produção de infovis. Normalmente, compartilhamento e comentário são ações participativas concebidas independentemente das características do dispositivo infovis em questão.

Do ponto de vista da produção de infovis e dos possíveis desdobramentos que a infografia pode alcançar no ambiente digital, on-line, interativo, multimídia, participativo, etc., interessa-nos debruçar sobre o nível de interatividade de registro, caracterizado, em nossa análise, por ações participativas que possibilitam aos usuários gerar novos conteúdos dentro do interface visual-interativa do infovis. Ações participativas de nível de registro promovem comunicação de ida e volta, de muitos para muitos e de entrelaçamento social entre interagentes. Recursos interativos de exploração do conteúdo ${ }^{74}$ diferenciam-se de ações participativas, pois seus alcances comunicacionais são diferentes. Enquanto os primeiros são recursos tecnológicos pré-programados pelos produtores do conteúdo, mas que permitem modelos comunicacionais direcionados pelo usuário em diversos gradientes, somente por meio das ações participativas há, de fato, certo empoderamento do usuário, que passa a ser mais propriamente interagente comunicacional (PRIMO, 2003), à medida que assume postura mais autônoma, autoral e criativa ao gerar novos conteúdos semântico-sintáticos por meio da interface visual-interativa do infovis. A seguir, apresentarmos três peças do nosso corpus que demonstram, exemplarmente, a possibilidade de conteúdos serem gerados por usuários na interface do infovis. É importante destacar que apenas dez peças da amostra total (4\%) apresentaram tal qualidade participativa, cinco pertencentes ao The New York Times, e cinco ao The Guardian.

A peça You decide the 2012 US presidential election (TGU_1204) (Figura 36), publicada pelo The Guardian em 5 de novembro de 2012, representa possíveis cenários de vitória para os candidatos presidenciáveis Barack Obama e Mitt Romney, nas disputas eleitorais norte-americanas em 2012, com base na quantidade de votos que cada estado da Federação possui.

\footnotetext{
${ }^{74}$ Interatividade do tipo usuário/conteúdo - avançar/retroceder ou iniciar, roll over, zoom, filtragem, relação, busca, extração, customização, outro painel de controle, e hipertextualidade.
} 


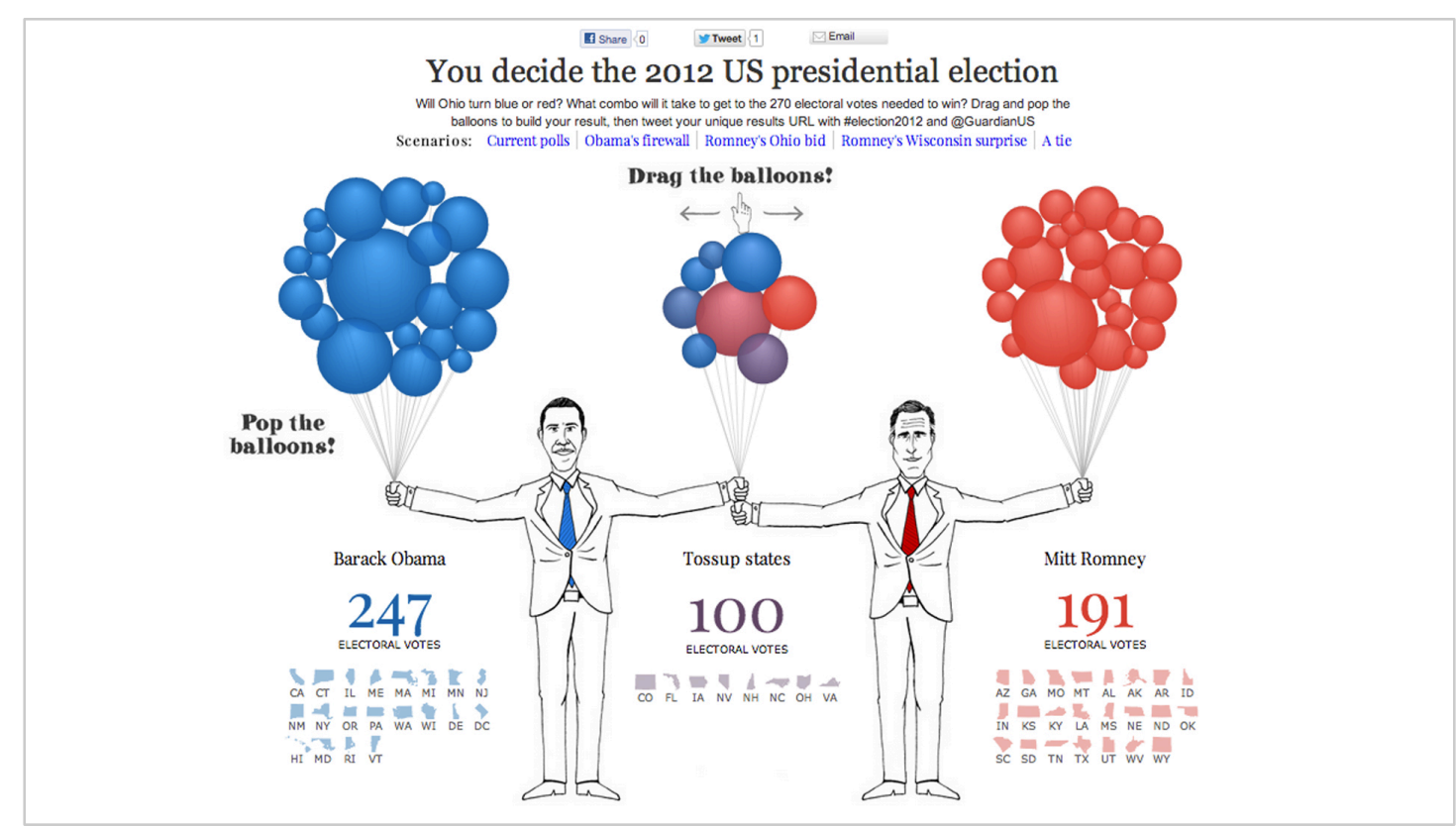

Figura 36 - You decide the 2012 US presidential election. Fonte: The Guardian ${ }^{75}$

Esse infovis assemelha-se, em termos semântico-pragmáticos, à peça The Electoral Map (NYT_1210), já discutida neste capítulo (p. 141-142 e p. 160-163), e ambos se caracterizam por ser dispositivos infovis com equilíbrio entre modelos comunicacionais 'direcionado pelo autor' e 'direcionado pelo usuário'. Ademais dos recursos de tratamento jornalístico que caracterizam a peça - título, texto explicativo, crédito, nota e multimídia - e recursos interativos de exploração do conteúdo - roll over, filtragem, relação, customização, outro painel de controle -, destaca-se a qualidade de ação participativa que usuários podem exercer sobre esse infovis, configurando nível de interatividade de registro. Além de explorar cenários de vitória para cada candidato sugeridos pela publicação, usuários são convidados a manifestar suas opiniões sobre os resultados eleitorais. A participação ocorre por meio de duas interações consecutivas. Em um primeiro momento, usuários exercem tarefa interativa de customização (RODRIGUES, 2010, p. 9), que lhes permite manusear elementos (no caso, círculos coloridos que representam estados do país) para gerar novas configurações visuais. Em um segundo momento, usuários podem compartilhar, pelo Twitter, Facebook ou e-mail, configurações visuais que tenham produzido com base no cenário eleitoral que desejam ou preveem que aconteça. Somente por meio dessa segunda ação, o nível de interatividade de registro do

75 Disponível em: <http://www.theguardian.com/world/interactive/2012/nov/05/you-decide-the-presidentialelection-interactive $>$. Acesso em abr. 2014. 
dispositivo infovis, a nosso ver, é alcançado, pois usuários, ao intervir semântica e sintaticamente sobre configurações visuais segundo seus pontos de vista, registrando-as e redistribuindo-as para outras audiências (conteúdo gerado pelo usuário), tornam-se, também, coprodutores ativos do infovis. ${ }^{76}$

Já a peça Do you think Scotland should become independent? (TGU_1219) (Figura 37), publicada pelo The Guardian em 9 de janeiro de 2012, foi desenvolvida em circunstância do possível referendo sobre a independência da Escócia que seria promovido no Reino Unido, na época de sua veiculação. Esse infovis, antecipando possíveis cenários de referendo nacional, promove enquete com usuários da publicação.

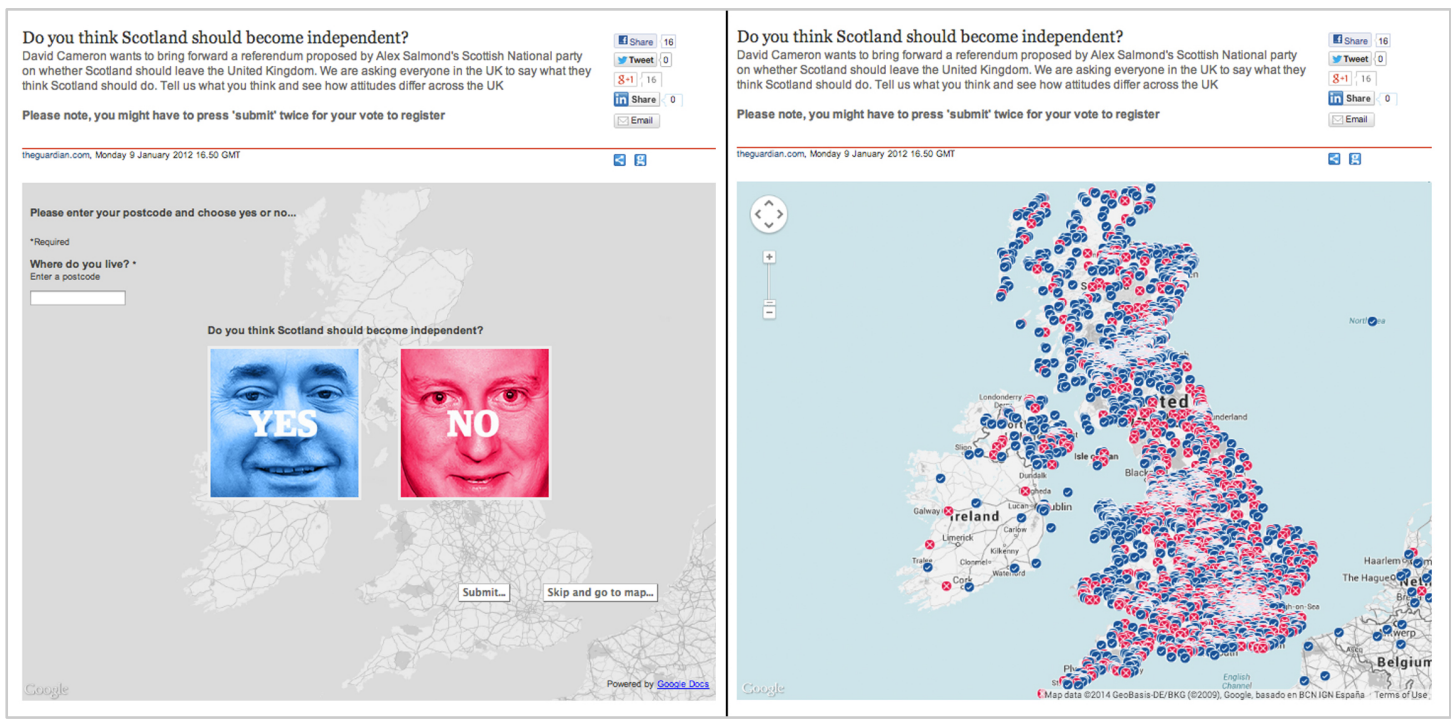

Figura 37 - Do you think Scotland should become independent? Fonte: The Guardian, 2012. ${ }^{77}$

A peça permite que usuários apenas explorem respostas já computadas para a pergunta Você acha que a Escócia deveria tornar-se independente?, distribuídas em um mapa e agrupadas (sim, em azul, e não, em vermelho), ou, então, participe da enquete contribuindo com seus votos. Nessa segunda modalidade de interação, usuários contribuem diretamente para produção do conteúdo visualizado no infovis, registram suas respostas e estabelecem interações sociais com o dispositivo infovis e com outros

\footnotetext{
${ }^{76}$ Nesses infovis, ações participativas não são mais computadas pelo dispositivo, restando aos usuários recursos interativos de exploração do conteúdo. Contudo, ainda consideramos que essas peças possuem nível de interatividade de registro, pois parte do conteúdo visualizado foi gerada por usuários.

77 Disponível em: <http://www.theguardian.com/politics/interactive/2012/jan/09/scotland-independencereferendum>. Acesso em abr. 2014.
} 
interagentes. Outra peça do The Guardian possui características semelhantes às desse infovis: Would you describe yourself as British? (TGU_1103).

Outro exemplo de infovis que possui, em sua interface visual-interativa, conteúdo parcialmente gerado pelo usuário é a peça What One Word Describes Your Current State of Mind? (NYT_1011) (Figura 38). Esse infovis, publicado pelo The New York Times em $1^{\circ}$ de novembro de 2010, foi produzido em decorrência das eleições presidenciais dos Estados Unidos naquele ano, com o objetivo de constituir interface na qual usuários pudessem registrar palavras que descrevessem seus estados de espírito nos dias que antecederam o pleito.

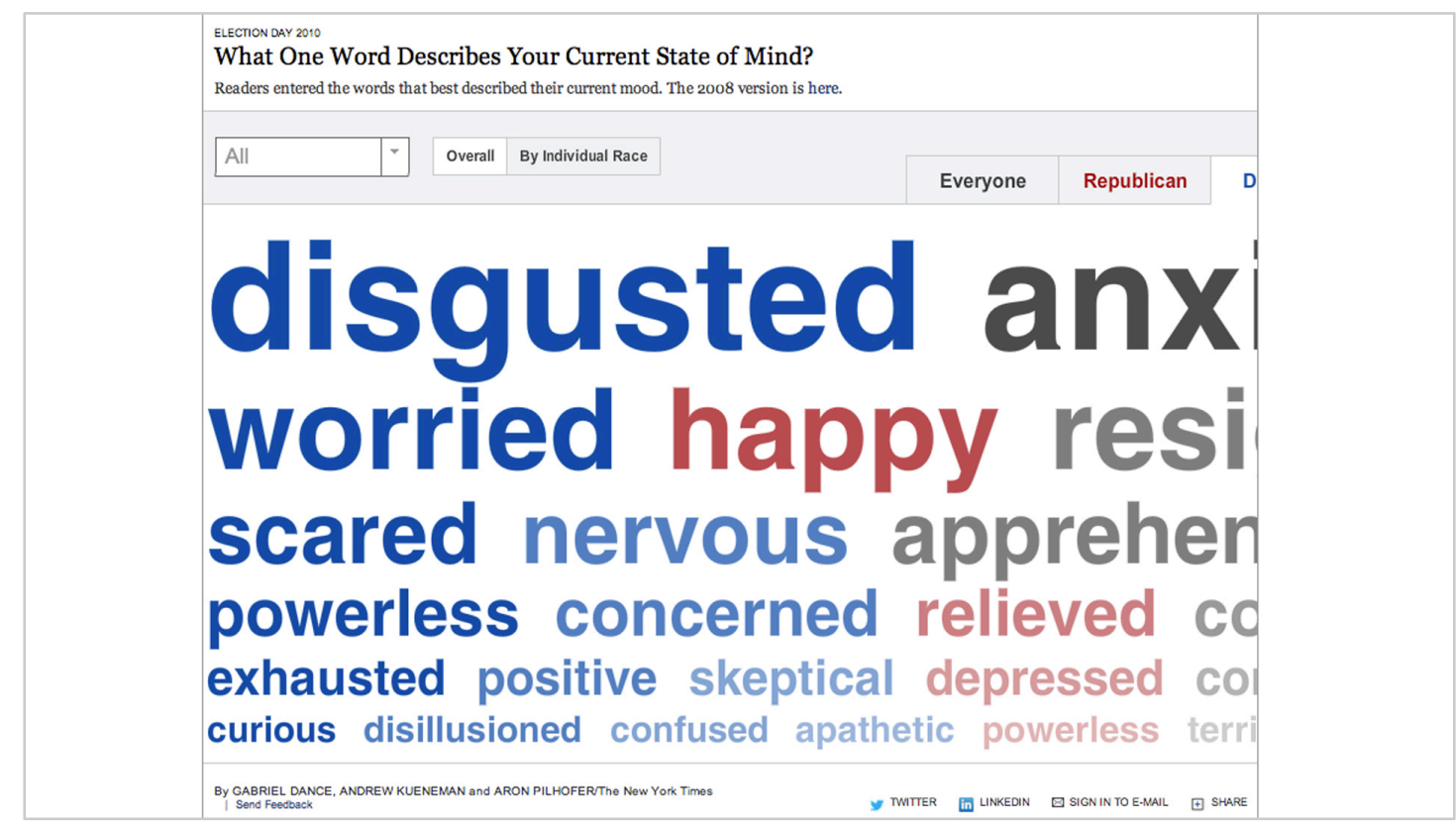

Figura 38 - What One Word Describes Your Current State of Mind? Fonte: The New York Times, 2010. ${ }^{78}$

A peça permite aos usuários explorar conteúdos informativos por meio de recursos interativos ou, então, participar ativamente da proposta do infovis, registrando palavras que melhor descrevam seus ânimos pré-eleitorais. Palavras são agrupadas por cores que correspondem à preferência partidária (republicana ou democrata) dos interagentes que participam, enquanto o corpo usado nas palavras (tamanho) indica quantidade de vezes que elas foram mencionadas por diferente interagentes.

Os títulos das últimas três peças analisadas - 1) Você decide as eleições presidenciais dos Estados Unidos de 2012; 2) Você acha que a Escócia deveria tornar-

78 Disponível em: <http://www.nytimes.com/interactive/2010/11/01/us/politics/2010-election-wordtrain.html>. Acesso em abr. 2014. 
se independente? e 3) Que palavra descreve a sua sensação atual? (destaques nossos) - apontam distanciamento do discurso referencial utilizado, tradicionalmente, na comunicação jornalística, que "[...] fala de algo no mundo, exterior ao emissor, ao receptor e ao processo de comunicação em si" (LAGE, 1986, p. 39), e empoderamento do usuário frente a uma realidade que não lhe é mais totalmente apresentada em canais unidirecionais, mas sim construída conjuntamente, mediante os esforços de diferentes interagentes.

Se, por um lado, constamos que, em determinados casos, o dispositivo infovis distancia-se do discurso referencial típico do Jornalismo e permite que usuáriosinteragentes constituam polos mais ativos da produção do conteúdo, por outro lado, não preconizamos o desaparecimento de modalidades mais mediadas e explanatórias de infográficos. No entanto, notamos que o nível de interatividade de registro, quando incorporado no dispositivo infovis aproxima-o de discussões recentes, próprias do jornalismo participativo também chamado de jornalismo colaborativo, jornalismo cidadão, webjornalismo, jornalismo open source:

A abertura de sites noticiosos à construção participativa de notícias e ao seu debate levanta novas questões não apenas sobre o webjornalismo, mas também exige renovados debates em torno do sistema produtivo e dos próprios ideais jornalísticos (PRIMO; TRÄSEL, 2006, p. 2).

Embora não seja característica predominante no corpus da pesquisa, a observação e análise das peças que apresentam ação participativa nos permite inferir que conteúdos gerados na interface visual-interativa do infovis, por diversos interagentes, representam o que há de mais avançado, em termos comunicacionais, na produção infográfica atual. Acreditamos que interações mais participativas frente ao dispositivo infovis, ainda que preestabelecidas por escolhas dos mediadores e monitoradas por ações de gatekeeping, refletem recente, pioneira e distintiva prática infográfica no ambiente on-line, que acompanha transformações das práticas comunicativas contemporâneas. Como afirma Gillmor “[...] na nova era das comunicações digitais, com múltiplas direções, o público pode tornar-se parte integral do processo [de produção de notícias] - e começa a tornar-se evidente que tem de o ser” (GILLMOR, 2005, apud PRIMO; TRÄSEL, 2006, p. 1). 


\section{Considerações finais}

Ao longo da pesquisa, nos propusemos a investigar o infovis, um infográfico interativo com base no cruzamento de dados e em sua organização texto-visual, que se configura como objeto de estudo emergente e inaugura novas qualidades na produção infográfica jornalística, sintonizadas com práticas comunicativas contemporâneas. Para tal, realizou-se, nos dois primeiros capítulos da dissertação, revisão bibliográfica sobre referências teóricas e práticas que incidem sobre o infovis: visualização da informação, infografia jornalística e interatividade. A partir da revisão e contextualização, estabelecemos as bases conceituais para problematizar nosso objeto em torno da polarização entre duas abordagens comunicacionais com ênfases diferentes, mas não excludentes: modelo 'direcionado pelo autor', que representa a força da interface gráfico-comunicativa mediada pelos produtores do conteúdo, e modelo 'direcionado pelo usuário', que representa as estratégias interativas e participativas dos consumidores do conteúdo.

A análise de conteúdo, apresentada no capítulo Proposta de análise de infovis, compôs nossa metodologia de pesquisa para construção de protocolo analítico que avalie o infovis como dispositivo estruturado por três dimensões interligadas - input, interface e output - e gere resultados, discutidos no capítulo Interpretação dos dados, sobre o panorama atual e futuro para a produção infográfica em sítios jornalísticos. A seleção das peças por amostragem constituiu corpus com diferentes níveis de elaboração gráfico-interativa e complexidade de produção, de modo que pudéssemos investigar a presença e ausência de determinadas características comunicativas dentro de cenário produtivo heterogêneo. O fato de o nosso corpus ser de recorte político, sobretudo eleitoral, e pertencente a quatro veículos comunicativos - The New York Times, The Guardian, Folha de S. Paulo e O Estado de S. Paulo - aponta a necessidade de diferenciar, em nossa pesquisa, resultados específicos da amostra e inferências que possam ser expandidas para outros infovis e para possíveis encaminhamentos para produção infográfica realizada no ambiente on-line. 
A seguir, listamos e comentamos, sucintamente, as principais conclusões apresentadas e discutidas no capítulo anterior, destacando que elas constituem aspectos relevantes para delimitar potencialidades, cenários futuros e desafios para o infovis que, em última análise, repercutem sobre o estado da arte da disciplina infografia.

1. A evidência quantitativa constitui o modo de organização da informação predominante em infovis de conteúdo político em todos os veículos comunicativos analisados. No entanto, ela é raramente visualizada de modo isolado em uma mesma peça, de forma que dados quantitativos, quase sempre, são cruzados com dados de outra natureza de organização (temporal, grupal, conectiva ou geográfica), apontando a predominância de peças híbridas sobre peças primárias. The New York Times é o único veículo, em nossa amostra, que apresenta peças com quatro e cinco modos de organização da informação, simultaneamente, o que demostra seu pioneirismo na produção de infovis de conteúdo e codificação visual complexos.

2. A produção infográfica aumenta ou diminui segundo fatores contextuais. Em nossa amostra, a publicação de infovis de conteúdo político aumenta, em todas as publicações, em anos com mais eventos eleitorais realizados nos países de edição dos veículos comunicativos analisados. Paralelamente, a criação de seções jornalísticas on-line especializadas em jornalismo de dados - como Datablog, do The Guardian; Estadão de Dados, de O Estado de S. Paulo; e FolhaSPDados, da Folha de S. Paulo, assim como seções equivalentes de outro veículos comunicativos - estimula o desenvolvimento de infovis, tanto de conteúdo político como de outros domínios semânticos, a partir de um modelo produtivo diferenciado, com base em atividades jornalísticas observadoras e curadoras, que buscam coletar dados, cruzá-los, organizá-los e representa-los visualmente.

3. Infovis, em todas as publicações analisadas, tendem a subutilizar recursos interativos para exploração do conteúdo (avançar/retroceder ou iniciar, roll over, zoom, filtragem, relação, busca, extração, customização, outro painel de controle, e hipertextualidade) e, de modo geral, enfatizam a abordagem comunicacional 'direcionada pelo autor', que representa modelo mais explanatório, com ênfase na linearidade, mediação e tratamento narrativo-jornalístico por parte dos comunicadores. The New York Times é o veículo cujas peças analisadas alcançam maior média de gradiente de interatividade, o que reflete, no polo receptor, 
possibilidades mais autônomas e individuais de percursos informativos e acesso ao conhecimento, ainda que o gradiente de mediação seja superior ao gradiente de interatividade na maioria de seus infovis.

4. Paralelamente, os veículos The Guardian e O Estado de S. Paulo utilizam o recurso interativo extração de dados e a ação participativa comentário, em seus infovis, de modo mais deliberado do que The New York Times e Folha de S. Paulo. O recurso interativo extração de dados, em infovis, proporciona processos de apropriação e ressignificação do conteúdo, à medida que faculta aos usuários o acesso e download dos dados brutos. Já a ação participativa comentário permite aos usuários tornar-se emissores de opiniões, sugestões, críticas e discussões, concretizando diálogos com outros usuários ou com os produtores do conteúdo. Tendo em vista esses aspectos, pode-se dizer que The Guardian e O Estado de S. Paulo manifestam ações de abertura comunicacional à audiência enquanto The New York Times e Folha de S. Paulo apresentam maior controle editorial sobre seus infovis.

5. O emprego de ferramentas on-line e gratuitas - como Google Fusion Tables, Tableau Public, Plotly, Infogr.am, etc. - para criação visual-interativa de infovis, torna seu processo produtivo mais acessível e veloz, acompanha a prática do jornalismo de dados e confere autonomia a não especialistas em Design e infografia na criação de infovis. Projetos de infovis mais complexos e elaborados exigem, no entanto, a combinação de conhecimentos e habilidades diferenciadas e o desenvolvimento de peças customizadas, tarefas mais dificilmente realizadas apenas por profissionais com parcas noções de Design utilizando exclusivamente templates de ferramentas como as citadas. O Estado de S. Paulo é, entre os veículos analisados, o que mais utiliza ferramentas on-line e gratuitas para produção da interface visual-interativa de seus infovis. A maioria das peças de O Estado de S. Paulo que indicam a utilização dessas ferramentas (cerca de 70\%), contudo, está atrelada ao Estadão Dados, seção especializada em jornalismo de dados e responsável por incentivar jornalistas envolvidos a desenvolver posturas e habilidades interdisciplinares na coleta, análise e apresentação texto-visual dos dados. Paralelamente, The New York Times é o veículo que menos indica o emprego de ferramentas on-line e gratuitas para produção de seus infovis (apenas uma em 81 peças) e que mais apresenta peças autorais e customizadas. Podemos 
atribuir essa constatação ao fato de a publicação não apresentar infovis associados a seções especializadas em jornalismo de dados e a práticas de open data (como Estadão Dados, Datablog e FolhaSPDados) e possuir, reconhecidamente, forte padrão de qualidade de seus produtos infográficos, a ponto de não encorajar a utilização mais assídua de tecnologias open source como os já mencionados Google Fusion Tables, Tableau Public, etc.

6. Atualização contínua configura-se como nova qualidade para o panorama atual e futuro de produção de infovis e de outras modalidades infográficas do jornalismo on-line, pois agrega valores de monitoramento e real time (tempo real) a infovis desenvolvidos e circulados na internet. The New York Times configura-se como o veículo comunicativo, analisado nesta pesquisa, que mais explora a qualidade tecnológica da atualização contínua dos dados representados em seus infovis.

7. Conteúdos gerados e registrados por usuários, na interface visual-interativa de infovis, representam o que há de mais avançado e inovador, em termos comunicacionais, na produção infográfica atual. Essa ação participativa não apenas levanta renovadas questões sobre o estado da arte da infografia, como também incide sobre contemporâneas reflexões em torno do sistema produtivo e dos próprios ideais jornalísticos. Permitir aos usuários participar mais ativamente do processo produtivo do infovis, ainda que suas ações sejam, muitas vezes, préprogramadas e monitoradas por escolhas dos mediadores, significa promover comunicação de ida e volta, de muitos para muitos e de entrelaçamento social entre interagentes. Novamente, as peças do The New York Times destacam-se, com as do The Guardian, no emprego da ação participativa conteúdo gerado pelo usuário, ainda que a incidência dessa nova qualidade infográfica seja discreta quando a observamos na amostra.

Acreditamos que as novas qualidades, atividades profissionais e tecnologias envolvidas na produção infográfica observadas e discutidas nesta dissertação a partir de análise de infovis, uma modalidade infográfica emergente, não esgotam as possibilidades de reflexão sobre o tema, mas constituem aspectos teóricos e práticos da Comunicação e do Design fundamentais para contribuir com avanços nos estudos em infografia e buscar a sistematização de uma prática comunicacional que fortalece o paradigma da interatividade entre produtores e consumidores de conteúdo. 


\section{Referências bibliográficas}

ABRAMO, C. W. Lei de Acesso à Informação no Brasil: um longo caminho a percorrer. In: GRAY, J.; BOUNEGRU, L.; CHAMBERS, L. (Org.) Manual de Jornalismo de Dados. Open Knowledge Foundation, [2014?]. Disponível em: < http://datajournalismhandbook.org/pt/ getting_data_2.html>. Acesso em: jan. 2014.

ALVIN, A. C. Ser ou não ser como o NYTimes? Eis a questão. In: Mostra Nacional de Infografia, São Paulo. p. 9-14, 2012.

AMARAL, R. Infográfico jornalístico de terceira geração: análise do uso da multimidialidade na infografia. Dissertação (Mestrado em Jornalismo) - Programa de Pós graduação em Jornalismo, UFSC, Florianópolis, 2010.

BARBOSA, S. Jornalismo Digital em Bases de Dados (JDBD): um paradigma para produtos jornalísticos digitais dinâmicos. Tese (Doutorado em Comunicação e Cultura Contemporâneas) - FACOM, UFBA, Salvador, 2007.

BERELSON, B. Content analysis in communications research. New York: Free Press, 1952.

BERTIN, J. Semiology of Graphics: diagrams, networks, maps. Tradução William J. Berg. California: Esri Press, 2010.

A Neográfica e o tratamento da informação. Tradução Cecília Westphalen. Curitiba: Editora UFPR, 1986.

. La Graphique. Communications. Paris, n. 15, p.169-185, 1970.

BONSIEPE, G. Design as a tool for cognitive metabolism: from knowledge production to knowledge participation. In: INTERNATIONAL SYMPOSIUM ON THE DIMENSIONS OF INDUSTRIAL DESIGN RESEARCH. Milano: Politecnico di Milano, 2000.

BRAGA, J.L. Interação como contexto da Comunicação. MATRIZes, São Paulo, ano 6, n. 1, p. 21-41, 2012a.

Circuitos versus campos sociais. In: MATTOS, M.; JUNIOR, J.;JACKS, N. (Org.). Mediação \& Midiatização. Salvador: EDUFBA, p. 31-52, 2012b.

Dispositivos Interacionais. Apresentado ao Grupo de Trabalho Epistemologia da Comunicação, no XX Encontro da Compós. Porto Alegre, UFRGS, 2011.

BRUNS, A. Blogs, Wikipedia, Second Life, and beyond. From production to produsage. New York: Peterlang, 2008.

BURKE, P. Testemunha ocular: história da imagem. São Paulo: EDUSC, 2004. 
CAIRO, A. Annotation, narrative, and storytelling in infographics and visualization. The Functional Art. 2014a. Disponível em: <http://www.thefunctionalart.com/2014/04/ annotation-narrative-and-storytelling.html>. Acesso em abr. 2014.

Plot.ly and Graf.ly: Interactive visualization for the masses. The Functional Art. 2014b. Disponível em: <http://www.thefunctionalart.com/2014/02/plotly-and-graflyinteractive-data.html>. Acesso em: mar. 2014.

Malofiej 2014, The Program. The Functional Art. 2014c. Disponível em: <http:// www.thefunctionalart.com/2014/01/malofiej-2014-program.html>. Acesso em: mar. 2014/

The functional art: an introduction to information visualization graphics and visualization. Berkeley: New Riders, 2013.

Thematic Maps: Statistics and Cartography. [2013?]. Disponível em: $<$ https:// knightcenter.utexas.edu/mooc/CartographyForJournalists.pdf>. Acesso em fev. 2013.

Bringing Infographics And Visualization to The Mainstream: Not Just the Tools, but the Ideas. Peachpit. 2012. Disponível em: $<$ http://www.peachpit.com/articles/article. aspx?p=1945830>. Acesso em mar. 2014.

Alamut. 2008.

Infografía 2.0: visualización interactiva de información en prensa. Madrid:

CAMEIRA, M. Os EUA, as estatísticas e a infografia. Infografando. 2008. Disponível em: $<$ http://infografando.blogspot.com.br/2008/10/os-eua-as-estatsticas-e-infografia.html >. Acesso em mar. 2014.

CARD, S.; MACKINLAY, J.; SHNEIDERMAN. Readings in information visualization: using vision to think. San Francisco: Morgan Kaufmann Publishers, 1999.

CASTELLS, M. A era da informação: economia, sociedade e rede. São Paulo: Paz e Terra, 2010.

A galáxia da internet: reflexões sobre a internet, os negócios e a sociedade.

Rio de Janeiro: Zahar, 2001.

CHIMENO, M. El efecto de los hitos en la infografía interactiva: un estudio comparativo basado en el 11-S. Tese (Doutorado em Comunicação) - Facultad de Comunicación, Universidad Pontificia de Salamanca, Salamanca, 2003.

CLEVELAND, W. S. The Elements of Graphing Data. Summit, NJ: Hobart Press, 1994.

CORDEIRO,W. R. Infografia interativa na redação: o exemplo do Diário do Nordeste. Mossoró: Sarau das Letras, 2013.

COSTA, J. La Esquemática. Barcelona: Paidós, 1998.

CIUCCARELLI, P. Turning visualizations into stories and "big pictures". In RENDGEN, S; WIEDEMANN, J (Ed). Information Graphics. Cologne: Taschen, 2012, p. 77-95. 
COX, A. Interview with Amanda Cox - Graphics Editor at the New York Times. Simply Statistics. 2012. Disponível em: < http://simplystatistics.org/2012/06/01/interview-withamanda-cox-graphics-editor-at-the-new $>$. Acesso em mar. 2014.

DATABLOG. Open data journalism at The Guardian. 2012. Disponível em: $<$ http://www. theguardian.com/media/datablog/2012/mar/07/open-data-journalism>. Acesso em jan. 2014,

DE PABLOS, J. M. Infoperiodismo. El periodista como creador de Infografia. Madrid: Editorial Sínteses, 1999.

DERVIN, B. Chaos, order, and sense-making: a proposed theory for information design. In: JACOBSON, R. (Org.). Information Design. Cambridge: MIT Press, 2000, p. 35-57.

DÜRSTELER, J. C. Visualización de información: una visita guiada. Barcelona: Ediciones Gestión 2000, 2003.

DYER, Z. Conteúdo gerado pelo usuário ganha importância na produção de notícias hiperlocais. Journalism in the Americas. 2013 Disponível em:

$<$ https://knightcenter.utexas.edu/pt-br/comment/reply/13835>. Acesso em: fev. 2014.

EDITORA ABRIL. Manual de estilo Editora Abril: como escrever bem para nossas revistas. Rio de Janeiro: Nova Fronteira, 1990.

EMERY, E. História da imprensa nos Estados Unidos. Rio de Janeiro: Editora Lidador, 1965.

ENGELHARDT, Y. The language of graphics: a framework for the analysis of syntax and meaning in maps, charts and diagrams. Dissertation (Master of Logic) - Institute for Logic, Language and Computation, Universiteit van Amsterdam, 2002.

ERREA, J. Por qué la infografia salvará a los diarios. In: PEREZ, A.; GIL. A. (Ed.).

15 Premios Internacionales de Infografia Malofiej. Pamplona: SND-E/Universidad de Navarra, 2008, p. 56-71.

ESTADÃO DADOS. Sobre. Disponível em: <http://blog.estadaodados.com/sobre/>. Fev. 2014.

FALEIROS, G. Cartograma. Folha de S. Paulo. 2012. Disponível em: $<$ http://folhaspdados. blogfolha.uol.com.br/2012/10/29/"cartograma-os-partidos-ganhadores-de-acordo-com-otamanho-do-eleitorado/>. Acesso em: mar. 2014.

FAUSTO NETO, A. As bordas da circulação. Alceu, Rio de Janeiro, v. 10, n. 20, p. 55-69, 2010.

FERRARI, P. Jornalismo Digital. São Paulo: Contexto, 2004.

FERREIRA, A. B. H. Dicionário Aurélio Digital. Rio de Janeiro: Nova Fronteira, 1999.

FEW, S. Now you see it: simple visualization techniques for quantitative analysis. Oakland: Analytics Press, 2009.

FOUCAULT, M. Microfísica do poder. Rio de Janeiro: Graal, 2004.

FRASCARA, J. ¿Qué es el diseño de información? $1^{\text {a }}$ ed. Buenos Aires: Infinito, 2011. 
GUIMARÃES, L. Acerca do Jornalismo Visual: busca pela delimitação da investigação das imagens no jornalismo. In: XXXV INTERCOM, 2012, Fortaleza. Anais ... Fortaleza, 2012.

HEER, J.; BOSTOCK, M.; OGIEVETSKY, V. A Tour Through the Visualization Zoo.

Communications of the ACM, v. 53, n. 6, p. 59-67, 2010.

HERSCOVITZ, H. G. Análise de conteúdo em jornalismo. In: LAGO, C.; BENETTI, M. Metodologia de pesquisa em jornalismo. Petrópolis: Vozes, 2010.

HOLMES, N. The best in diagrammatic graphics. Mies: Rotovision, 1993.

HORN, R. Information Design: emergence of a new profession. In: JACOBSON, R. (Org.). Information Design. Cambridge: MIT Press, 2000. p. 15-33.

IAB (Interactive Advertising Bureau). UGC, Social Media and Advertising. 2008. Disponível em:<http://www.iab.net/media/file/2008_ugc_platform.pdf>. Acesso em: jan. 2014.

INFOGR.AM. Press info. Disponível em: <http://blog.infogr.am/press>. Acesso em mai. 2014.

JACOBSON, R. Introduction: Why Information Design Matters. In: JACOBSON, R. (Org.). Information Design. Cambridge: MIT Press, 2000. p. 1-11.

JENKINS, H. Cultura da convergência. São Paulo: Aleph, 2011.

KANNO, M. Os dois gráficos que eu mais gosto de mostrar em um seminário para jornalistas da Abraji. 2008. Disponível em: <www.scribd.com/doc/8405991/SeminarioKannoAbraji $>$. Acesso em: set. 2013.

KANNO, M.; BRANDÃO, R. Manual de Infografia. Folha de S. Paulo, São Paulo, 1998. Disponível em: <http://www.scribd.com/fullscreen/8448371?access_key=key-16jres5y8hvvzh 4ob1xt>. Acesso em: out. 2012.

KEEBLE, R. The newspapers handbook. Londres: Routledge, 1994.

KOSARA, R. Stories Are Gateways Into Worlds. Eager Eyes: Visualization and Visual Communication. 2014. Disponível em: < http://eagereyes.org/blog/2014/stories-are-gatewaysinto-worlds>. Acesso em abr. 2014.

. Tableau Public. Eager Eyes: Visualization and Visual Communication. 2010.

Disponível em: <http://eagereyes.org/blog/2010/tableau-public >. Acesso em fev. 2014.

. Visualization criticism: the missing link between information visualization and art. In: INTERNATIONAL CONFERENCE INFORMATION VISUALIZATION, 2007, Zurique. Proceedings ... Zurique, 2007, p. 631-636.

KOVACH, B.; ROSENSTIEL, T. Os elementos do jornalismo. Tradução de Wladir Dupont. São Paulo: Geração Editorial, 2003.

KUNCZIK, M. Conceitos de jornalismo: Norte e Sul. Manual de Comunicação. São Paulo: Edusp/Com-Arte, 1997. 
KRIPPENDORFF, K. Content Analysis: an introduction to its methodology. $2^{\text {nd }}$ ed. Thousand Oaks: Sage, 2004.

LAGE, N. Estrutura da notícia. São Paulo: Ática, 1986.

LEAL, B. S. As estéticas do jornalismo em transformação: perspectivas de pesquisa em comunicação. In: SILVA, G; KÜNSCH, D.; BERGER, C.; ALBUQUERQUE, A. (Org.). Jornalismo Contemporâneo: figurações, impasses e perspectivas. Salvador: EDUFBA; Brasília: Compós, 2011, p. 104-117.

LEMOS, A. Cibercultura: tecnologia e vida social na cultura contemporânea. 5 ed. Porto Alegre: Sulina, 2010.

LENGLER, R; EPPLER, M. J. Towards a periodic table of visualization methods for management. In: INTERNATIONAL CONFERENCE ON GRAPHICS AND

VISUALIZATION IN ENGINEERING, 2007, Florida. Proceedings ... Florida, 2007, p. 83-88.

LETURIA, E. ¿Qué es el infografia? Revista Latina de Comunicación Social, n. 4, 1998.

LÉVY, P. Inteligência coletiva: por uma antropologia do ciberespaço. São Paulo: Loyola, 1999.

LIMA, R. Análise da Infografia Jornalística. Dissertação (Mestrado em Design) -ESDI, UERJ, Rio de Janeiro, 2009.

LONGMAN Dictionary of Contemporary English. $5^{\text {th }}$. ed. Essex: Pearson, 2009.

LUCAS, R. J. L. Infografia jornalística: uma revisão bibliográfica necessária. In: X CONGRESSO ALAICA, 2010, Bogotá. Anais ... Bogotá, 2010.

MACHADO, E. Banco de Dados como espaço de composição multimídia. In: BARBOSA, Suzana (Org.). Jornalismo digital de terceira geração, v. 1, Covilhã, Universidade da Beira Interior, 2007, p. 103-117.

MANOVICH, L. O que é visualização? Estudos de Jornalismo e Mídia, Florianópolis, v. 8, n. 1, p. 146-172, jan.-jun. 2011.

The language of new media. London: MIT Press, 2001.

MARTINS FILHO, E. L. (Ed.). Manual de redação e estilo de O Estado de S. Paulo. São Paulo: O Estado de S. Paulo, 1990.

MCNAIR, B. Journalism and democracy. In: WAHL-JORGENSEN, K.; HANITZSCH, T. (Ed.) The handbook of journalism studies. London: Routledge, 2009, p. 237-249.

MEGGS, P. B.; PURVIS, A. W. História do Design Gráfico. São Paulo: Cosac Naify, 2009.

MIELNICZUK, L. Jornalismo on-line e os espaços do leitor: um estudo de caso do NetEstado. Dissertação (Mestrado em Comunicação e Informação) - PPGCOM, UFRGS. Porto Alegre, 1998.

MILLS-BROWN, L. Journalism, Political. In: KAID, L.; HOLTZ-BACHA, C. (Ed.)

Encyclopedia of Political Communication. Thousand Oaks: Sage, 2008, p. 297-298. 
MORAES, A. Infografia: o design da notícia. Dissertação (Mestrado em Design) - PUC-RJ, Rio de Janeiro, 1998.

MOSTRA DE INFOGRAFIA. Organizado por Infolide. Disponível em: $<$ http:// www.infolide.com/p/mostra-de-infografia.html>. Acesso em: 29 set. 2012.

MURRAY, J. H. Hamlet no Holodeck: o futuro da narrativa no ciberespaço. São Paulo: Itaú Cultural/Unesp, 2003.

NICHANI, M., RAJAMANICKAM, V. Interactive visual explainers: A simple classification. Elearning post. 2003. Disponível em $<\mathrm{http}$ //www.elearningpost.com/articles/archives/ interactive_visual_explainers_a_simple_classification >. Acesso em: set. 2012.

PALACIOS, M. Jornalismo online, informação e memória: apontamentos para debate. In: FIDALGO, A.; SERRA, P. (Org.). Informação e Comunicação Online, v.1 - Jornalismo Online. Covilhã: Universidade da Beira Interior, Livros LabCom, 2003.

PALACIOS, M.; MIELNICZUK, L.; BARBOSA, S.; RIBAS, B.; NARITA, S. Um mapeamento de características e tendências no jornalismo online brasileiro e português. In: CONGRESSO ANUAL EM CIÊNCIA DA COMUNICAÇÃO, XXV, Salvador, 2002. Anais ... Salvador, 2002.

PASSOS, R.; MOURA, M. Design da informação na hipermídia. Infodesign, v. 4, n. 2, p. 19 27, 2007.

PASQUALL, A. Um breve glossário descritivo sobre comunicação e informação. In: MARQUES DE MELO, J.; SATHLER,L. Direitos à Comunicação na Sociedade da Informação. São Bernardo do Campo: Unesp, 2005.

PELTZER, G. Jornalismo iconográfico. Lisboa: Planeta Editora, 1992.

PEREIRA, G. M. Q. Infojornalismo nos jornais diários: análise de coberturas no jornal Folha de S. Paulo. Dissertação (Mestrado em Ciências da Comunicação) - PPGCOM, USP, São Paulo, 2006.

PLAZA, J. Arte e interatividade: autor-obra-recepção. Ars, São Paulo, n. 2, p. 9-29, 2003.

PRIMO, A. Quão interativo é o hipertexto? Da interface potencial à escrita coletiva.

Fronteiras: Estudos Midiáticos, São Leopoldo, v. 5, n.2, p. 125-142, 2003

PRIMO, A.; TRÄSEL, M. R. Webjornalismo participativo e a produção aberta de notícias. Contracampo, Niterói, v. 14, p. 37-56, 2006.

RABAÇA, C. A.; BARBOSA, G. Dicionário de comunicação. São Paulo: Editora Ática, 1987.

REDIG, J. Não há cidadania sem informação, nem informação sem design. Revista Brasileira de Design da Informação, São Paulo, v. 1, n. 1, p. 47-56, 2004.

RIBAS, B. A Narrativa webjornalística: um estudo sobre modelos de composição no ciberespaço. Dissertação (Mestrado em Comunicação e Cultura Contemporâneas) - FACOM, UFBA, Salvador, 2005a. 
Ser Infográfico. Apropriações e limites do conceito de infografia no campo do

jornalismo. In: ENCONTRO NACIONAL DE PESQUISADORES EM JORNALISMO, 3., 2005, Florianópolis. Anais... Florianópolis, 2005b.

RICHARDS, C.J. Getting the picture: diagram design and the information revolution.

Information Design Journal, v.9, n. 2-3, p. 87-110, 2000.

Diagrammatics: An investigation aimed at providing a theoretical framework for studying diagrams and for establishing a taxonomy of their fundamental modes of graphic organization. Ph.D. thesis, Royal College off Art, London, 1984.

ROAM, D. The back of the napkin. New York: Portfolio, 2008.

RODRIGUES, A. Visualizar o "invisível": era da infoestética no jornalismo de dados. In: $10^{\circ}$ ENCONTRO NACIONAL DE PESQUISADORES EM JORNALISMO, 2012, Curitiba. Anais ... Curitiba, 2012.

. Visualização de dados na construção infográfica: abordagem sobre um objeto em mutação. In: XXXIII INTERCOM, 2010, Caxias do Sul. Anais ... Caxias do Sul. 2010.

Infografia em base de dados no jornalismo digital. Dissertação (Mestrado em Comunicação e Cultura Contemporâneas) - FACOM, UFBA, Salvador, 2009.

ROGERS, S. Facts are sacred - The power of data. Kindle edition. London: The Guardian Books, 2011.

O faça-você-mesmo da visualização de dados: nossas ferramentas favoritas. In: GRAY, J.; BOUNEGRU, L.; CHAMBERS, L. (Org.) Manual de Jornalismo de Dados. Open Knowledge Foundation, [2014?]. Disponível em: < http://datajournalismhandbook.org/pt/ getting_data_2.html>. Acesso em: jan. 2014.

SAAD CORREAA, E.; BERTOCCHI, D. A cena cibercultural do jornalismo contemporâneo: web semântica, algoritmos, aplicativos e curadoria. MATRIZes, São Paulo, Ano 5, n. 2, p. 123-144, 2012.

SALAVERRÍA, R. Redacción periodística en internet. Barcelona: EUNSA, 2005.

SANCHO, J. L. V. La infografia digital en el ciberperiodismo. Revista Latina de Comunicación Social, La Laguna, v. 63, p. 492-504, 2008.

La Infografia: técnicas, análisis y usos periodísticos. Barcelona: Universitat Autònoma de Barcelona, 2001.

SCHUDSON, M. The power of news. Cambridge: Harvard University Press, 2003.

SCHWINGEL, C. Ciberjornalismo. São Paulo: Paulinas, 2012.

SEGEL, E.; HEER, J. Narrative Visualization: telling stories with data. IEEE Transactions on Visualization and Computer Graphics, v. 16, p. 1139-1148, 2010.

SHEDROFF, N. Information interaction design: a unified field theory of design. In:

JACOBSON, Robert (Org.). Information Design. London: MIT Press, 2000, p. 267-292. 
SHNEIDERMAN, B. The eyes have it: a task by data type taxonomy for information visualizations. In: IEEE SYMPOSIUM ON VISUAL LANGUAGES, 1996, Boulder, Colorado. Proceedings... Boulder, 1999, p. 336-343.

SILVEIRA, L. Modelo de caracterização de infográficos: uma proposta para análise e aplicação jornalística. Dissertação (Mestrado em Ciências da Comunicação) - PPGCOM, USP, São Paulo, 2010.

SOJO, C. A. Es la infografía un género periodístico? Revista Latina de Comunicación Social, La Laguna, v. 51, 2002.

TEIXEIRA, T. Infografia e jornalismo: conceitos, análises e perspectivas. Salvador: EFUFBA. 2010.

Promessas para o futuro: as características do infográfico no ciberjornalismo a partir de um estudo exploratório. In: 6o ENCONTRO NACIONAL DE PESQUISADORES EM JORNALISMO, 2008, São Paulo. Anais ... São Paulo, 2008.

TEIXEIRA, T. G.; RINALDI, Mayara. Promessas para o futuro: as características do infográfico no ciberjornalismo a partir de um estudo exploratório. In: $6^{\circ}$ ENCONTRO NACIONAL DE PESQUISADORES EM JORNALISMO, 2008, S. Bernardo do Campo. Anais ... Brasília, 2008.

TEIXEIRA, W.; ROCHA, A. Visualização de dados estruturada por bancos de dados digitais sintoniza o Jornalismo com a complexidade informativa contemporânea. In: XXXIII INTERCOM, 2010, Caxias do Sul. Anais ... Caxias do Sul, 2010.

TELLERIA, A. S. Design ciberjornalístico: evolução, critérios e desafios. MATRIZes, São Paulo, Ano 5, n. 2., p. 269-285, 2012.

THE ECONOMIST. Monstrous amount of data. The Economist. 2010. Disponível em: $<$ http://www.economist.com/node/15557421>. Acesso em jun. 2013.

TOLEDO, J. R. Basômetro. Vídeo de seminário. 2013. Disponível em: <http://www.youtube $. c o m /$ watch? $=$ Bv0JMoAG17U \&feature=youtu.be $>$.

TRAQUINA, N. Teorias do jornalismo Vol. 1 - Porque as notícias são como são. Florianópolis: Insular, 2005.

TUFTE, E. R. Envisioning Information. Cheshire: Graphics Press, 1990. The Visual Display of Quantitative Information. Cheshire: Graphics Press, 1983.

VICKERY, G.; WUNSCH-VINCENT, S. Participative Web: User-Created Content. Paris: OECD. 2007. Disponível em: <http://www.oecd.org/sti/38393115.pdf >. Acesso em: fev. 2014.

WARE, C. Information Visualization: Perception for Design. 2 ed. San Francisco: Morgan Kaufmann Publishers, 2004.

WOLF, M. Teorias das comunicações de massa. São Paulo: Martins Fontes. 2010.

WURMAN, R. S. Ansiedade de informação. Como transformar informação em compreensão. São Paulo: Cultura Editores Associados, 1991. 